\title{
SANDS AND ENVIRONMENTAL CONDITIONS IMPACT THE ABUNDANCE AND PERSISTENCE OF THE FECAL INDICATOR BACTERIA ENTEROCOCCUS AT RECREATIONAL BEACHES
}

\author{
By \\ Elizabeth Halliday \\ B.S., University of Maryland, 2007 \\ Submitted in partial fulfillment of the requirements for the degree of \\ Doctor of Philosophy \\ at the \\ MASSACHUSETTS INSTITUTE OF TECHNOLOGY \\ and the \\ WOODS HOLE OCEANOGRAPHIC INSTITUTION
}

September 2012

(C) 2012 Elizabeth Halliday

All rights reserved.

The author hereby grants to MIT and WHOI permission to distribute publicly paper and electronic copies in whole or in part in any medium now known or hereafter created.

Signature of Author

Joint Program in Oceanography and Applied бcean Science and Engineering Massachusetts Institute of Technology and Woods Hole Oceanographic Institution

August 22, 2012

Certified by

Dr. Rebecca Gast
,Thesis Supervisor

Accepted by

D̆r. Michael Neubert

Chair, Joint Committee for Biological Oceanography

Woods Hole Oceanographic Institution 


\title{
SANDS AND ENVIRONMENTAL CONDITIONS IMPACT THE ABUNDANCE AND PERSISTENCE OF THE FECAL INDICATOR BACTERIA ENTEROCOCCUS AT RECREATIONAL BEACHES
}

\author{
By \\ Elizabeth Halliday \\ Submitted to the Department of Biology on August 22, 2012 in Partial Fulfillment of the \\ Requirements for Degree of Doctor of Philosophy in Biological Oceanography
}

\begin{abstract}
The marine fecal indicator Enterococcus is measured at beaches to detect fecal contamination events, and beaches are closed to bathers when Enterococcus is found to exceed the federally mandated limit. This dissertation presents evidence that beach sands are an environmental reservoir of enterococci, tests the relationship between beach sand enterococci and water quality measurements, examines how real-time environmental conditions measured at beaches can be used to better understand and predict water quality violations, and uses molecular methods to provide an alternative characterization of water and sand fecal contamination. Initially, a qPCR method was developed and applied to monitor enterococci DNA in sands. Subsequently this qPCR method was used in tandem with traditional detection of culturable enterococci in sand and water at recreational beaches that have closures every summer. One field season was spent in Maine at beaches in the Wells National Estuarine Research Reserve, where high frequency water and weather measurements are routinely collected in situ. Two field seasons were spent at the beach in Provincetown Harbor, Massachusetts, where a weather station and ADCP were deployed to characterize the environmental conditions associated with observations of elevated enterococci. All studies revealed that environmental variables were related to the distribution of enterococci in sands and water, with water temperature and tides having the strongest relationship to enterococci in water. In dry weather, elevated enterococci in sands were strongly related to the increased moisture content of sands during spring tides. These environmental variables were used in multiple linear regressions to explain a significant amount of the variation observed in environmental enterococci abundance, which notably had no relationship to molecular markers of human fecal pollution. Results suggest that under certain conditions sands can contribute bacteria to the water and that tidal cycles, which are not taken into account in monitoring schemes, can bias routine sampling.

Thesis supervisor: Dr. Rebecca Gast

Title: Associate Scientist, Woods Hole Oceanographic Institution Department of Biology
\end{abstract}




\section{Acknowledgements Page}

Many wonderful people have contributed to this dissertation, in myriad ways.

First and foremost, this work is dedicated to my advisor, Dr. Becky Gast, the first person to introduce me to the world of molecular biology and microbes, from which there was no turning back! Becky is a fantastic scientist and a good friend. She has generously let me find my own path but has always provided incredible support, even when it meant driving hours to the beach with me to sample the tides in the middle of the night so I wouldn't have to do it alone. I have learned so much in her lab and will always appreciate the opportunities she made possible.

I would like to thank my committee for seeing me through the twists and turns of this dissertation, and taking the time to help me work through the challenges that inevitably arose. Your interdisciplinary backgrounds have helped me see problems from new perspectives, and your comments have improved this work immensely.

It has been a pleasure and privilege to be part of the Woods Hole community for so many years. I would like to thank my classmates and colleagues for both the entertaining shenanigans and thought provoking conversations we've had.

Thanks to my amazing parents, Kate and Bob, for their constant love, support, and excellent sense of humor, all of which have helped me tremendously over the past five years. Thanks for letting me paint sea creatures on my bedroom walls and thoroughly encouraging me to be a marine biologist so many years ago. More materially, thanks for the hundreds of miles you let me put on the Camry in pursuit of sand samples. This work would not have been possible without you.

And finally, I would like to acknowledge the person who has been by my side through this entire journey, who has lugged coolers down beaches and spent weekends enduring black flies in the pursuit of sampling. He has seen me through graduate school applications, MIT finals, qualifying exams, multiple sampling seasons, paper drafts, and weekends of PCR. He has vacuumed sand out of the car and helped me learn $\mathrm{R}$. He has even made me think like an engineer, a little. Jeff, your love and support during the last five years has made everything possible, and more importantly, so much fun. Thank you.

$$
* * *
$$

This work was funded though a fellowship and student research grant from the Woods Hole Coastal Ocean Institute, as well as a grant through the Woods Hole Ocean Venture Institute. Thanks to WHOI Academic Programs for their support of my work in the Joint Program. Additionally, this research was supported by the National Science Foundation grant OCE0430724, and the National Institute of Environmental Health Sciences grant P50ES012742 to the Woods Hole Center for Ocean and Human Health. 


\section{Table of Contents}

1. Chapter 1: Introduction (8)

1.1. Background: Protecting water quality at recreational beaches in America (8)

1.2. Dissertation organization (10)

2. Chapter 2: Bacteria in Beach Sands: An emerging challenge in protecting coastal water quality and bather health (13)

2.1. Chapter 2: Addendum to Figure 1 (24)

3. Chapter 3: Use of an exogenous plasmid standard and quantitative PCR to monitor spatial and temporal distribution of Enterococcus spp. in beach sands (25)

3.1. Chapter 3: Addendum, Strategies currently used to correct qPCR-based estimates of environmental FIB (35)

4. Chapter 4: Enterococci in sands and water at estuarine beaches in southern ME (37)

4.1. Introduction (37)

4.2. Methods (39)

4.3. Results and Discussion (44)

4.4. Conclusions (58)

4.5. References (61)

5. Chapter 5: Dry-weather distribution of enterococci in sands and water at Provincetown (63)

5.1. Introduction (63)

5.2. Methods (65)

5.3. Results (66)

5.4. Discussion (83)

5.5. Supplemental information (88)

5.6. References (100)

6. Chapter 6: Pyrosequencing analysis of bacterial communities in sands and water at anthropogenically impacted beaches (103)

6.1. Introduction (103)

6.2. Materials and Methods (105)

6.3. Results (110)

6.4. Discussion (118)

6.5. References (123)

7. Chapter 7: Conclusions (127)

7.1. Sands are a reservoir of fecal indicator bacteria at beaches (127)

7.2. Environmental variables influence the distribution of enterococci in sands and water at beaches (124)

7.3. Relating enterococci abundance and nonpoint source pollution to human health risks (125)

7.4. References (134)

8. Appendix A: Experiments examining transfer of enterococci from sand to water (137) 


\section{Index of Figures}

2.1 (Figure 1) Pathways of Fecal Indicator Bacteria into and out of beach sands (15)

3.1 (Figure 1) Sampling sites at Avalon Bay, Catalina Island, CA, USA, shown aerially (27)

3.2 (Figure 2) qPCR Standard curve threshold cycles (28)

3.3 (Figure 3) Recovery of Enterococcus spp. DNA in wet sand at Avalon sampling sites (30)

3.4 (Figure 4) Enterococcus spp. DNA recovered from Avalon beach sand (30)

3.5 (Figure 5) Enterococcus spp. in Avalon Bay beach sand, 2007 (31)

3.6 (Figure 6) Enterococcus spp. in Avalon Bay beach sand, 2008 (31)

3.7 (Figure 7) Results of sand DNA exchange of Avalon Beach samples (32)

4.1 (Figure 1) Study site, east of the Route 1 corridor in Southern Maine (40)

4.2 (Figure 2) Environmental variables measured in situ at Wells Harbor and the Wells Estuarine Research Reserve Weather Station during the field study (40)

4.3 (Figure 3) Distribution of Enterococcus in all water, wet sand and dry sand samples during the study period (46)

4.4 (Figure 4) Measurements of enterococci abundance at Wells Harbor and at Wells Beach, before and after a major precipitation event (50)

5.1 (Figure 1) Daily mean concentrations of ENT at the beaches of Provincetown Harbor (68)

5.2 (Figure 2) Characterizing the relationship between intertidal sands, moisture content and log ENT per dry weight sand (69)

5.3 (Figure 3) Tidal impact on ENT densities in water, intertidal wet sand, and dry sand (74)

5.4 (Figure 4) Schematic of subterranean groundwater estuary (81)

6.1 (Figure 1) Sites sampled at Provincetown Harbor, MA and at Avalon Bay, CA (106)

6.2 (Figure 2) Relative abundance of phyla containing $>1 \%$ of total sequence tags (110)

6.3 (Figure 3) NMDS plot of total bacterial community composition in samples (113)

6.4 (Figure 4) Potential pathogen presence among days, site and sample type (118)

7.1 (Figure 1) Conceptual model of intertidal loads and fluxes impacting concentrations of FIB in coastal bathing waters (129) 
7.2 (Figure 2) Patterns of bacterial contamination can be identified when FIB measurements are supplemented with data characterizing the water, weather, site and regional cycles (132) Appendix A (Figure 1) Results from shaking experiments (144)

\section{Index of Tables}

2.1 (Table 1) Observations of FIB Decay and Growth in Beach Environments (16)

2.2 (Table 2) Examples of Reported Concentrations of FIB in Beach Sands (17)

3.1 (Table 1) Assessment of pGEM recovery and amplification (29)

3.2 (Table 2) Sand sample exchange qPCR data, presented in units of ENT cells/uL (32)

4.1 (Table 1) Correlations between monitoring method, sample type and survey sits (53)

4.2 (Table 2) A comparison of diagnostic multiple linear regression models using culturable and molecular markers of water quality as response variables (54)

5.1 (Table 1) Results from hourly sampling along the beach around a high tide (72)

6.1 (Table 1) Beach sand samples sequenced in study (107) 


\section{CHAPTER 1: INTRODUCTION}

\subsection{Background: Protecting water quality at recreational beaches in America}

Pathogens in ambient recreational waters are regulated under the Clean Water Act, and fecal indicator bacteria are used as standards to identify waters with unacceptable levels of pathogen

pollution, as recommended by the United States Environmental Protection Agency (9). The goal in applying these standards is to protect bathers from exposure pathogens that can cause gastrointestinal illness, respiratory disease, and infections of the eye, ear and skin. In 2000, Congress passed an amendment to the Clean Water Act called the Beaches Environmental Assessment and Coastal Health (BEACH) Act, which mandated the enforcement of bacterial water quality standards at all coastal recreational beaches. At the time, several states did not have any programs in place for monitoring coastal waters (3).

Although the Clean Water Act had a very positive impact on bacterial water quality, including major reductions in the amount of fecal bacteria discharged into waters through the requirement for secondary treatment of sewage, bacteria continue to be the leading cause of water quality impairment for rivers and ocean shorelines due primarily to agricultural and urban runoff/stormwater sewers, respectively (1). Stormwater amalgamates fecal bacteria from many sources including homes, domestic animals and wildlife, and runoff over impervious surfaces facilitates transport to beaches. Studies of the coastal watersheds in North Carolina have shown that the mean amounts of fecal indicators in waters are directly related to the amount of impervious surface in the water shed (6). Furthermore, impervious surface area in coastal zones is projected to increase as populations continue to grow along the coasts (2). Aging sewage infrastructure, improperly maintained septic systems, and illegal discharge can also jeopardize 
water quality. In the dynamic coastal ocean, these contamination events can be short or longlived; definitively identifying sources of the pollution to target for remediation can be difficult. In recent years the majority of water quality violations at beaches have been due to bacteria from unknown sources, detected through routine monitoring (2).

When bathers are inadequately protected from coastal pollution the cost of health care and work days lost to illness can be substantial. Nationally, the annual health costs associated with gastrointestinal illness acquired at beaches has been estimated to be 300 million dollars (8). Annual losses due to bathing-associated gastroenteritis in Los Angeles and Orange County, CA, were estimated to cost between 21 and 51 million dollars (4). Likewise, substantial economic costs are incurred by coastal communities each day beaches are closed and recreational opportunities are lost (7).

Despite a shifting landscape of bacterial pollutant sources and the rise of many promising new biochemical and molecular methods for detecting fecal indicators and discriminating between human and animal fecal input (5), the same culture-based methods recommended in 1986 are being used today to monitor fecal indicator bacteria at beaches. Because cells must grow on selective media to be identified, it takes more than a day before results from water quality tests are known. The fundamental flaw within this system is that beach closures frequently come a day too late for the bathers who were already exposed to polluted waters, and by the time the beach is closed to bathers the water might actually be clean again - however, reopening a beach requires repeating the slow process of incubating samples for a day and counting colonies.

Most recently, another potential problem with the monitoring paradigm has been documented. The accumulating evidence that fecal indicators persist in the environment has disproved a long- 
held assumption of water quality monitoring, which is that high levels of fecal indicator bacteria in environmental samples indicates that they have been recently contaminated and present a risk to human health.

The overarching goal of this dissertation is to examine the abundance and persistence of the fecal indicator bacteria Enterococcus in the surfzone environment at beaches thought to be impacted by varied sources and amounts of fecal pollution. More specifically, the research presented herein probes the role of beach sands as a reservoir for enterococci and the repercussions enterococci populations in sands may have on bathing water quality.

\subsection{Organization of the Dissertation}

This introductory chapter is the first of seven chapters presented within the dissertation. The second chapter is a survey of the scientific literature describing the current knowledge of the presence, growth and decay of fecal indicator bacteria in beach sands from subtropical and temperate environments around the world. Chapter 2 contextualizes the motivations for the research presented in later chapters; namely, the concern that detection of true public health risks may be obscured by the proliferation of enterococci in the environment, balanced by the concern that sands may be a reservoir for both indicator bacteria and pathogens constituting a public health risk either through direct contact with sands or through contact via bathing with bacteria transported to waters from sands. Chapter 2 was published in 2011 and is reprinted with permission from Environmental Science \& Technology.

The third chapter describes a qPCR method developed to examine the abundance of enterococci in beach sand. It was tested with samples collected as part of a major sampling effort undertaken by the Southern California Coastal Water Research Program to compare many different culture 
and DNA-based methods of detecting fecal indicators and pathogens. Samples were collected at Avalon beach on Catalina Island, where the water violate water quality standards more than $25 \%$ of the time. Chapter 3 was published in 2010 and is reprinted with permission from Limnology and Oceanography: Methods.

The qPCR method described in Chapter 3 was subsequently applied to DNA samples extracted from sands and water during the field campaigns described in Chapter $\mathbf{4}$ and Chapter 5. These studies employed standard monitoring methods and qPCR to survey Enterococcus in beach sands, to examine the relationship between Enterococcus and environmental variables in water and sands of the surfzone environment, and to use diagnostic multiple linear regression to model water quality during the sampling period.

The focus of Chapter $\mathbf{4}$ is an intensive month-long field study carried out at Wells, a popular recreational destination in southern Maine. The study area includes high-energy barrier beaches and a harbor beach at the mouth of a tidal river, which routinely flushes the upper reaches of the watershed's protected salt marshes and intensely developed highway corridor. The bacterial data collected is augmented by 15-minute interval in situ water quality and meteorological data collected by the Wells Estuarine Research Reserve, as part of the National Oceanic and Atmospheric Administration's long-term System Wide Monitoring Program.

The focus of Chapter 5 is the study of the sand and water along a section of beach in Provicetown Harbor, MA that has recurring wet and dry weather bacterial water quality violations. Over twelve weeks of multi-day sampling in dry weather, the dynamics driving the proliferation of Enterococcus in beach sand and the environmental factors associated with variability in water quality were documented and analyzed. 
Chapter 6 utilizes a subset of the DNA samples collected in Chapter $\mathbf{3}$ and Chapter $\mathbf{5}$ to contextualize changes in the abundance of Enterococcus within the total bacterial communities in sand and water. 454 pyrosequencing generated short sequence tags that were used to compare the communities in sands and water at the two different sites, as well as to examine the presence of sequence tags belonging to a broader group of alternative fecal indicators and potential pathogens.

Finally, Chapter 7 discusses the overarching conclusions drawn from the research chapters, and the implications of these results on approaches to monitoring water quality at beaches.

\subsection{References}

1. Arnone, R. D., and J. P. Walling. 2007. Waterborne pathogens in urban watersheds. Journal of water and health 5:149.

2. Beach, D. 2003. Coastal sprawl: The effects of urban design on aquatic ecosystems.

3. Dorfman, M., and K. S. Rosselot. 2011. Testing the Waters: A Guide to Water Quality at Vacation Beaches. National Resource Defense Council.

4. Given, S., L. H. Pendleton, and A. B. Boehm. 2006. Regional public health cost estimates of contaminated coastal waters: a case study of gastroenteritis at Southern California beaches. Environmental science \& technology 40:4851-4858.

5. Kinzelman, J., D. Kay, and K. Pond. 2011. Relating MST Results to Fecal Indicator Bacteria, Pathogens, and Standards. Microbial Source Tracking: Methods, Applications, and Case Studies:337-359.

6. Mallin, M. A., K. E. Williams, E. C. Esham, and R. P. Lowe. 2000. Effect of human development on bacteriological water quality in coastal watersheds. Ecological Applications 10:1047-1056.

7. Rabinovici, S. J. M., R. L. Bernknopf, A. M. Wein, D. L. Coursey, and R. L. Whitman. 2004. Economic and health risk trade-offs of swim closures at a Lake Michigan beach. Environmental science \& technology 38:2737-2745.

8. Ralston, E. P., H. Kite-Powell, and A. Beet. 2011. An estimate of the cost of acute health effects from food-and water-borne marine pathogens and toxins in the USA. Journal of water and health 9:680-694.

9. U.S.E.P.A. 1986. Ambient water quality for bacteria -1986. In O. o. Water (ed.), vol. 440/5-84-002, Washington, D.C. 
CHAPTER 2: Bacteria in Beach Sands: An Emerging Challenge in Protecting Coastal Water Quality and Bather Health

Reprinted with permission from Environmental Science and Technology 


\title{
Bacteria in Beach Sands: An Emerging Challenge in Protecting Coastal Water Quality and Bather Health
}

\author{
ELIZABETH HALLIDAY* AND REBECCA J. GAST \\ Woods Hole Center for Ocean and Human Health, Woods Hole \\ Oceanographic Institution, 3-24 Redfield Building, MS\#32, Woods Hole, \\ Massachusetts 02543, United States
}

Received August 11, 2010. Revised manuscript received November 19, 2010.

Accepted November 24, 2010.

To protect bather health at recreational beaches, fecal indicator bacterial standards are used to monitor water quality, and waters exceeding the standards are subsequently closed to bathers. However beachgoers are also in contact with beach sands, the sanitary quality of which is not included within beach monitoring programs. In fact, sands and sediments provide habitat where fecal bacterial populations may persist, and in some cases grow, in the coastal zone. Specific pathogens are less well studied in beach sands and sediments, but there is a body of evidence that they too may persist in these environments. This paper reviews the current state of knowledge regarding the abundance and distribution of fecal indicator bacteria and pathogens in beach sands of diverse climatological regions, and at beaches subjected to varied levels of anthropogenic impact. In all regions fecal indicator bacteria are nearly ubiquitous in beach sands, and similar relationships emerge among fecal indicator abundance in dry sand, submerged sands, and water. Taken together, these studies contextualize a potential public health issue and identify research questions that must be addressed in order to support future policy decisions.

\section{Introduction: Fecal Indicators As a Proxy for Water Quality}

Every year, bathing in coastal waters polluted with fecal contamination is estimated to cause more than 120 million cases of gastrointestinal illness and 50 million cases of respiratory disease around the world (1). These cases are caused by a diversity of fecal pathogens introduced into the aquatic environment by point sources such as wastewater treatment facilities and combined sewer overflows, or by diffuse nonpoint sources stemming from coastal and shoreline development, leaky septic tanks, urban runoff, agricultural runoff, discharge from boats, from bathers themselves, and from local animal populations (Figure 1). Because it is not feasible to monitor each of the viral, bacterial, and protozoan pathogens potentially present, culturable fecal indicator bacteria (FIB) that are correlated with disease in swimmers (usually gastrointestinal) are used as proxies for the presence of sewage-borne pathogens that put bather health at risk (e.g., 2, 3). A meta-analysis of twenty-two epidemiological studies conducted between 1953 and 1996 at beaches around the world (4) suggests a causal dose-related relationship between gastrointestinal symptoms and recreational water quality as measured by bacterial indicator counts (including total coliforms, fecal coliforms, enterococci,

* Corresponding author e-mail: ehalliday@whoi.edu. or E. coli). Among these studies, Enterococcus spp. (ENT) emerge as the indicator bacteria best correlated with health outcomes in marine systems, whereas E. coli (EC) are best correlated with health outcomes in fresh water systems.

\section{New Perspectives on Fecal Indicators in the Environment}

Researchers have questioned the efficacy of FIB standards (5) because several assumptions have been proven false, namely, that FIB cannot persist outside their host environment, and that recovery of FIB from the aquatic environment is indicative of the presence of disease-causing pathogens. In many cases, the abundance of FIB in recreational waters does not correlate with specific pathogens (e.g., 5-11) and discrepancies may reflect environmental or persistent FIB populations including bird guano $(12,13)$, FIB growing within vegetation or algal mats on lake shores (14), and FIB in beach sands. As early as 1967, EC and ENT were documented persisting for many days in soils and thereby contributed to "variations in bacterial count of storm-water runoff which have no relation to the sanitary history of the drainage area" (15).

The effects of sunlight and other environmental factors that limit survival of FIB in the water column have been well documented (e.g., 16-20), but the physical, chemical, and biotic factors influencing FIB survival in sediments and sands have only recently begun to be assessed $(21-24)$. A comparison of EC and ENT survival as measured in different studies is presented in Table 1 . This summary clearly shows that despite differences in methodological and experimental conditions, the loss of cells of both EC and ENT in fresh and seawater supports the assumption that they quickly die in recreational waters. In contrast, studies that examine the loss of EC and ENT cells in wet sand and water find that culturable bacteria persist longer in sand than in water (Table $1, \mathrm{~A})$, and some studies have documented growth of EC and ENT, rather than loss, in beach sands (Table 1, B).

A Nuanced Relationship between Indicators and Health Outcomes. The selection of FIB as microbiological water quality proxies was supported by strong epidemiological evidence (e.g., 2, 29-31) that FIB are consistently the best predictor of bather health outcomes at beaches affected by point source pollution. Epidemiological studies at beaches with nonpoint source pollution are fewer and have mixed success in correlating FIB abundance to bather health outcomes of enteric illness, respiratory and skin infections. At a beach in California affected primarily by nonpoint source pollution, no association was found between the abundance of traditional FIB and negative bather health outcomes (32), 


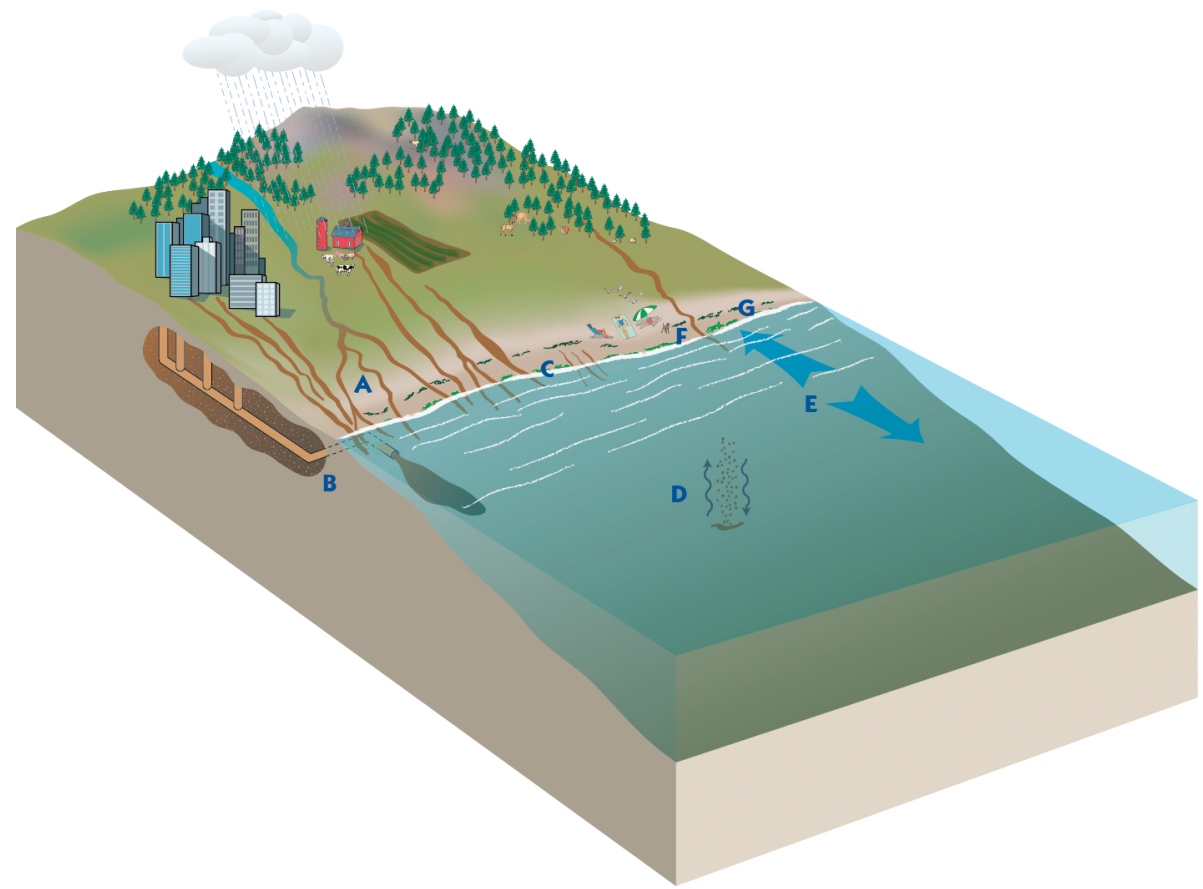

FIGURE 1. Pathways of fecal indicator bacteria (FIB) into and out of beach sands. (A) Runoff: Precipitation causes diffuse land-based runoff that concentrates FIB from urban areas (roadways, parking lots, gutters, lawns, pets), agriculture (overflow of animal waste), or feces from wildlife in the watershed into stormwater. Stormwater flows through local waterways or runs directly over beach sands into the intertidal zone. (B) Aging infrastructure: In urban areas with combined sewer overflows, heavy precipitation delivers a mix of urban runoff and raw sewage to beach sands and/or coastal waters, depending on outfall location and tidal stage. Leaky sewer infrastructure, failed septic systems, and buried drainage pipes in the coastal zone may also be sources of FIB to beach sands. (C) Swash zone: Periodic tidal rewetting enables FIB deposited in dry sands to persist or regrow, and waves may deliver FIB from the water column into the upper intertidal sands. (D) Exchange: Resuspension of sand into water by tidal or wind-driven waves may redistribute bacteria from sand to water; humans are then exposed to these bacteria when bathing. Likewise, deposition of particulate matter may introduce or return bacteria to the sand. Accretion of sands could bury FIB-rich sands at the beach, and erosion could alternately expose or relocate contaminated sands along the beach. (E) Water: Residence time of water at the beach may quickly remove or alternately retain bacteria near shore; thus, local hydrography and wind direction contribute to rates of removal or retention. (F) Fecal events: Animals (birds, dogs, wildlife, humans) on the beach may directly introduce FIB to sands, which can subsequently be redistributed over a greater area of beach by pedestrian traffic or weather events. (G) Additional refugia: Wrack, harboring robust bacterial populations seeded from land-based runoff or surfzone water, may shed FIB to sand or water during high tides.

but bathers in the study did have an increased incidence of diarrhea and skin rashes when compared to nonbathing beachgoers. In Florida, Fleisher et al. (33) also documented increased incidence of enteric, respiratory, and skin infections in bathers compared to nonbathers at a beach with nonpoint source microbial pollution; but among the symptoms, only skin rashes increased in a dose-dependent manner with measured ENT. These nonpoint source case studies are important to note because the majority of the approximately 20,000 beach advisories in the U.S. in 2008 were caused by nonpoint sources of bacterial pollution (34). Furthermore, despite increased monitoring and closures over the past decade, the Centers for Disease Control and Prevention concluded in a recent report that the incidence of infection associated with recreational water use has steadily increased over the past several decades as a result of emerging pathogens, increases in aquatic activities, and better disease reporting (35). The lessening of the relationship between FIB and bather health outcomes in cases of nonpoint source pollution suggests that the current water quality monitoring paradigm falls short of the goals of protecting human and environmental health. It is possible that environmental FIB populations, such as those in beach sands, contribute to this lack of correlation between indicator levels and disease symptoms.

Outside the Host: Environmental Reservoirs and Differential Survival of Enteric Bacteria. FIB are natural residents of the lower intestinal tract of humans and other warm-blooded animals. The host provides a consistently

warm and relatively nutrient-replete environment. Once outside their host, fecal bacteria may face osmotic stress, large variations in temperature and $\mathrm{pH}$, limited nutrient availability, and increased predation. Common fecal bacteria such as ENT and EC vary in their ability to deal with these environmental stressors. ENT typically display tolerance to extremes in $\mathrm{pH}$, temperature, salts, and detergents (36), and their surface hydrophobicity makes them more successful at utilizing starvation and biofilm modes of growth $(37,38)$. EC have been found to constitute a smaller fraction of particleassociated cells in the aquatic environment (39) and are relatively more sensitive to desiccation and inactivation by sunlight $(17,40)$. Abilities may further vary between bacterial strains or even within a population, due to differences in physiological state or growth stage (41). Nevertheless, nonhost environments may broadly be considered to be stressful (i.e., following introduction die-off can be measured) or permissive (characterized by persistence or growth) for enteric bacteria.

Stressful Environments. Experimental studies have shown that the effects of temperature (42), salinity (e.g., 42, 43) and sunlight (e.g., 17, 19) in aquatic environments are all factors contributing to the reduction in colony forming unit (CFU) recovery of EC and ENT over time in surface waters, with EC typically more sensitive than ENT to these effects. Thus, aquatic environments may be broadly considered stressful, but the reduction in recovery rates of culturable FIB from environmental waters should be treated cautiously. Enterococcus faecalis, like other nonsporulating bacteria, can respond to environmental stressors by altering its physiology 
TABLE 1. Observations of FIB Decay and Growth in Beach Environments

(A) Die-off rate constant $k\left(\right.$ day $\left.^{-1}\right)$, describing loss of culturable cells in beach waters and sands

\begin{tabular}{|c|c|c|c|c|}
\hline type of study & $\begin{array}{l}\text { measured loss of cells }\left(\log _{10} \mathrm{CFU}\right) \\
\text { over time in: }\end{array}$ & $K_{\mathrm{ENT}}$ & $K_{\mathrm{EC}}$ & reference \\
\hline \multirow[t]{2}{*}{ water mesocosm amended with sewage } & freshwater & 0.3387 & 0.2174 & 25 \\
\hline & seawater & 0.5262 & 1.3319 & \\
\hline \multirow[t]{2}{*}{ water mesocosm amended with sewage } & light seawater & $2.21^{a}$ & & 26 \\
\hline & dark seawater & 0.907 & & \\
\hline \multirow[t]{2}{*}{ model: best-fit to field observations } & light seawater & $7.0^{a}$ & 6.0 & 27 \\
\hline & dark seawater & 1.3 & 0.8 & \\
\hline \multirow{4}{*}{$\begin{array}{l}\text { sediment/water mesocosms amended with untreated } \\
\text { wastewater }\end{array}$} & freshwater & 0.27 & & 28 \\
\hline & freshwater sediment & 0.03 & & \\
\hline & seawater & 1.05 & & \\
\hline & seawater sediment & 0.22 & & \\
\hline \multirow[t]{4}{*}{ tropical beach sand mesocosms } & sterile sand & $0.006^{b}$ & $0.0379^{b}$ & 24 \\
\hline & sand with phage & $0.011^{b}$ & $0.0665^{b}$ & \\
\hline & sand with phage and bacteria & $0.0205^{b}$ & $0.337^{b}$ & \\
\hline & sand with phage, bacteria and protozoa & $0.0785^{b}$ & $0.3715^{b}$ & \\
\hline
\end{tabular}

(B) Observed doubling times $\left(\right.$ day $\left.^{-1}\right)$ in marine beach sands

\begin{tabular}{|c|c|c|c|c|}
\hline type of study: & sands subjected to: & ENT & EC & reference \\
\hline Florida beach sand mesocosms & $\begin{array}{l}\text { varied temperatures, salinities, nutrient } \\
\text { and moisture content }\end{array}$ & $1-0.44^{c}$ & $0.36-0.22^{c}$ & 21 \\
\hline California beach sand mesocosms & rewetting & $1.1-3.5$ & & 23 \\
\hline
\end{tabular}

to a starvation state whereby it persists without growing in the environment and is recovered by culture (45), or to a distinctly different viable but nonculturable (VBNC) state whereby cells are vegetative and not culturable, but can be visualized with viable count methods (46). Studies of the viability of $E$. faecalis in artificial seawater microcosms show that at least $80 \%$ of the cells remain viable when colonies can no longer be recovered (47), suggesting that VBNC ENT may persist in a dormant state in the environment. Likewise, in marine waters, enterotoxigenic EC strains have been documented entering the VBNC state upon exposure to sunlight, and subsequently persisting in the environment while retaining toxicity (48). Even when exposed to Antarctic waters, enteric bacteria were able to persist in VBNC states (49). These studies highlight one of the flaws of the culture-based method of indicator bacteria detection-the exclusion of VBNC cells that have the potential to impact health.

Permissive Environments. A survival strategy utilized by many allochthonous bacteria in aquatic environments is sorption to particulate matter. Studies have shown that EC persists longer in seawater and lake microcosms when sand or sediment is present $(42,50)$. Davies et al. (51) studied seeded EC in marine sediment by enumerating total culturable cells and total viable cells (via acridine orange direct counting) and found that over an experimental period of 68 days the same proportion of total EC remained culturable. Survival in sediment may be enhanced relative to water because of protection from sunlight/UV inactivation, buffered temperatures, and availability of nutrients accumulated from algae, debris, and plankton (e.g., 52). Bacteria may also be protected within biofilms on moist sand grains (53). In some geographical regions, highly favorable conditions may be encountered outside the host. In relatively warm, nutrientrich, pristine tropical soils and waters, EC have been found at densities far exceeding the concentrations found in highly polluted temperate waters (54). Fecal coliforms have been documented thriving in water trapped in bromeliads growing high within rainforest canopies where there is no significant fecal source (55), and decaying vegetation (56) and seaweed (57) have been identified as permissive environments for ENT.

In short, although in some cases they are well correlated with health outcomes, FIB and other allochthonous enteric bacteria have mechanisms to survive the stressors frequently found in aquatic environments, and environmentally adapted strains may establish indigenous populations that are not indicative of recent fecal contamination. Among pathogens, some may be particularly well adapted to life in the nonhost environment (58).

\section{FIB in Beach Sands within the United States}

Recreational waters in America are monitored with standard methods designed to protect human health, even though radical differences in climate, sand type, wave energy, and point and nonpoint sources of pollution may contribute to the bacterial concentrations in the water column. Likewise, the relative importance of beach sands as a reservoir of FIB may also vary at local or regional levels. A few studies have examined the effects of tide, current, and groundwater on the movement of FIB between the beach and water (59-63), and these reinforce the likelihood that a combination of coastal parameters effect the distribution and persistence of FIB and pathogens in sands and water. The generation of reactive oxygen species in beach sands and wrack (64) is a possible chemical parameter that may affect FIB persistence as well.

Representative environmental data from subtropical beaches, temperate coastal beaches and estuarine beaches, and Great Lakes beaches, normalized to CFU/100 g sand to facilitate comparisons with the units CFU/100 mL used in water quality management, are presented in Table 2 . Studies reported in this table $(23,52,65-68)$ were chosen because the sites vary in their climates and bacterial sources, but the data illustrate that in each of these regions, EC and ENT routinely vary by at least an order of magnitude from ambient water quality measurements and also can vary by an order 
TABLE 2. Examples of Reported Concentrations of FIB in Beach Sands

\begin{tabular}{|c|c|c|c|c|c|}
\hline site & organism & $\begin{array}{l}\text { type of sand } \\
\text { environment }\end{array}$ & concentration (CFU/100 g) & $\begin{array}{l}\text { ratio CFU } \\
\text { water:sand }\end{array}$ & reference \\
\hline \multirow[t]{2}{*}{ Chicago/Lake Michigan } & EC & submerged sand & $7.2 \times 10^{2}$ & 1:93 & $(52)$ \\
\hline & & dry sand & $4.0 \times 10^{3}$ & 1:17 & \\
\hline \multirow[t]{2}{*}{ Michigan/Lake Huron } & EC & wet sand & $1.4-9 \times 10^{2}$ & $1: 3-17$ & (65) \\
\hline & ENT & wet sand & $2-8 \times 10^{2}$ & $1: 4-38$ & \\
\hline \multirow[t]{2}{*}{ South Florida, marine beaches ${ }^{a}$} & ENT & wet sand & $1.9 \times 10^{2}$ & $1: 2-23$ & (66) \\
\hline & & dry sand & $2.429 \times 10^{3}$ & $1: 30-460$ & \\
\hline \multirow[t]{8}{*}{ South Florida river enbankments } & EC & muddy/steep & $6.0 \times 10^{3}$ & not reported & (67) \\
\hline & & muddy/flat & $1.42 \times 10^{6}$ & & \\
\hline & & muddy/dead end & $1.2 \times 10^{4}$ & & \\
\hline & & sandy & $1.5 \times 10^{4}$ & & \\
\hline & ENT & muddy/steep & $4.0 \times 10^{3}$ & & \\
\hline & & muddy/flat & $1.17 \times 10^{6}$ & & \\
\hline & & muddy/dead end & $2.0 \times 10^{3}$ & & \\
\hline & & sandy & $9.0 \times 10^{3}$ & & \\
\hline \multirow[t]{4}{*}{ Southern California Wetland sediments ${ }^{b}$} & ENT & "bird" impacted & $1.6 \times 10^{4}$ & not reported & (68) \\
\hline & & "urban" impacted & $1.36 \times 10^{5}$ & & \\
\hline & EC & "bird" impacted & $4.0 \times 10^{3}$ & & \\
\hline & & "urban" impacted & $3.8 \times 10^{4}$ & & \\
\hline \multirow[t]{2}{*}{ Southern California coastal sand ${ }^{c}$} & ENT & wet sand & $3.35 \times 10^{2}$ & $1: 2.5$ & (23) \\
\hline & & dry sand & $4.5 \times 10^{3}$ & 1:34 & \\
\hline
\end{tabular}

${ }^{a}$ This study reports high microscale variability in dry sands. ${ }^{b}$ This study reported geometric means in MPN/5 g sediment; adjusted here to $100 \mathrm{~g} .{ }^{c}$ Values are per $100 \mathrm{~g}$ dry weight. This table only includes samples collected at one time point from Lover's Point Beach for purposes of comparison. Many beaches were included in this study with EC and ENT levels ranging from undetectable to $6.2 \times 10^{4}$.

of magnitude or more in different sand types at the same site. However, directly comparing studies of indicator abundances such as those in Table 2 is complicated by the fact that there is extreme spatial and temporal variability at most sites. For example, at Lover's Point, the Southern California beach whose ENT concentrations are referenced in Table 2, the investigators studied spatial variability over a 24-h period and found that although in aggregated samples the dry sand had the highest concentrations of ENT, measurements of individual samples varied by 3 orders of magnitude from below their detection limit of approximately $5 \mathrm{CFU} / 100 \mathrm{~g}$, to $4452 \mathrm{CFU} / 100 \mathrm{~g}$ (95).

Additionally complicating direct comparisons among studies is the lack of a common method for measuring FIB in beach sands. Studies of FIB in beach sands have generally modified the protocol for detection of FIB in recreational waters by suspending sand in water, shaking, and then processing the supernatant as if it were a water sample. As such, there is great variability in how sand studies produce a sample (Supporting Information Table 1). There can be major differences in sand sample collection, including holding time before analysis, whether replicate samples were homogenized, whether sands were collected surficially or integrate some depth within the sand, and whether "wet sand" was submerged. The amount of sand actually tested varies from 5 to $200 \mathrm{~g}$ per sample (studies in Table 2). Also variable is the amount and type of eluant, how long the sands were shaken, whether they were shaken by hand or mechanically, and how long sands were allowed to settle before analysis of the eluant. Both of the EPA-approved methods of detection, membrane filtration to quantify colony-forming units and IDEXX plates to quantify most probable number (MPN), have been successfully used for detection in of FIB in sands. Only one study to date has compared many of the common methods and reagents used for FIB recovery from sand (69). Overall, most of the methods tested did not produce significant differences in recovery of FIB, but the authors suggested shaking sands suspended in water or PBS in a ratio of 1:10 by hand for $2 \mathrm{~min}$, with one rinse step and a settling time of $30 \mathrm{~s}$ as the optimal method (69). As studies of sand begin to follow the same method, comparisons among them will become more meaningful.
Subtropical Beaches. In subtropical environments such as Hawaii, FIB are frequently found at extremely elevated concentrations in freshwater streams. However, the source of FIB to these streams is not sewage or human waste but the local soils, which are broadly permissive for the growth of a diversity of fecal bacteria. At Hanauma Bay, a site in Hawaii that experienced declining water quality as it emerged as a tourist destination, transects from submerged sands to inland sands revealed that fecal coliform, EC, and ENT concentrations increased steadily and that the highest concentrations of bacteria were found in dry sand where people congregate to sunbathe and eat (70). The authors also recognized that endemic populations of pigeons had increased as the bay developed as a tourist destination. The pigeons were implicated in the contamination of the dry beach sands, whereas further inland, mongoose waste was suggested as a primary source of FIB to soils (70). In Hawaii, it has been shown that the dominant soil microflora have nutrient extraction capabilities superior to those of the EC and ENT, whose growth is limited by competition, but when excess nutrients and moisture become available both EC and ENT quickly respond and grow (40). Mesocosm experiments with tidally impacted subtropical sediments have also documented significant amounts of regrowth for both ENT and EC with the simulation of tides through wetting, and with the addition of sediment to water (67).

In the coastal environment, some bacterial strains may have the genetic potential to persist longer than others. Mesocosm experiments have tested the persistence of ENT isolates from sand, dog, and wastewater sources in subtropical (Gulf of Mexico) sediments and waters (28). In these experiments growth was never observed, but specific decay rates confirmed that ENT persists longer in sediment than in fresh water or seawater (28, Table 1$)$.

In 2007, Bonilla et al. (66) published the results of a study at three popular southern Florida beaches, each having different physical and chemical parameters, and found that FIB (both EC and ENT) were recovered at a 2-23-fold greater concentration in wet sand than in water and at a 30-460fold greater concentration in dry sands than water (Table 2). No correlations were found between environmental parameters and bacterial concentrations that would explain these 
results. The highest concentrations of FIB were found at $>5$ $\mathrm{m}$ landward from the tidal zone, in beach sand that would be infrequently wet. The intersample variability of ENT in sands was consistently high, and a seeding experiment showed that one fecal event from a gull could be spread over $3.1 \mathrm{~m}^{2}$ of beach sand by pedestrian and natural transport mechanisms. This suggested that small volume/high concentration inputs of bacteria could increase the number of culturable FIB over a fairly wide beach area, and potentially the water column. Other studies in the area (71) have also shown that the highest concentration of bacteria recorded in waters occurs at the high tide. DNA-based identification of ENT species in sands, water, feces, and sewage further implicated washout of the sand bacteria into recreational water in the area by showing that assemblages in wet sand and water were more similar (72).

As the Bonilla et al. (66) study found that ENT was statistically elevated in sand relative to water, they considered the potential health risks associated with exposure to sand with a pilot epidemiology study. Preliminary evidence suggested that only time spent in wet sand and time spent in water were associated with a dose-dependent increase in gastrointestinal illness. The culture methods used to detect both ENT and EC do not differentiate among species from different sources, such as from humans or animals or environmental strains. There may be different health impacts from the presence of nonhuman indicators, and this may be reflected in the lack of disease associated with dry sand exposure in their study.

Temperate, Coastal Beaches. Especially along the California coast, ENT have been shown to be nearly ubiquitous in beach sands (63) with exposed sands having significantly higher densities of ENT than submerged sands, and the highest densities located near the high tide line. Likewise, intertidal sites have been shown to have higher and more homogeneous concentrations of FIB than submerged marine sediments (73). Sand characteristics such as organic content, moisture content, and percentage fines have been shown to affect the densities of EC but not ENT (63), and natural ENT populations in beach sand transported to lab microcosms have been shown to grow in response to simulated tidal rewetting (23, Table 1B).

At Santa Monica Bay, including two open beaches and one sheltered beach, Lee et al. (74) measured FIB (both ENT and EC) levels in water and sediment prior to, during, and following a storm event. At the two open beaches, FIB concentrations in sediment peaked along with water column concentrations during the storm; both sediment and water populations declined after the storm. At the enclosed beach, FIB levels in water and sand were consistently high and did not appear well-correlated with the storm. Further analysis showed that levels of ENT at enclosed beaches were 2-3 orders of magnitude higher than all of the values observed at 11 open beaches, supporting the hypothesis that the physical environment at enclosed beaches supports environmental reservoirs of ENT in sediments. Using sterilized sediment and water from their study sites, Lee et al. (74) conducted benchtop microcosm studies and found that total culturable ENT remained constant over time in microcosms with water alone, but increased by 3 orders of magnitude in sediment-amended microcosms, and ENT survived even better in water amended with high organic-content sediment.

Temperate, Estuarine Beaches. Sands and sediments at estuarine beaches and coastal wetlands are noteworthy as potential sources of FIB to recreational waters, because particulate matter naturally settles out in these environments and may be resuspended during tidal or high erosional flow conditions (68). Fries et al. (39) examined the proportion of free FIB (both EC and ENT) versus particle-associated FIB in water in a time series at the Neuse River Estuary in North
Carolina, and found that $38 \%$ of the FIB in water were attached to particulate matter and thus capable of settling out of the water column. In the environment, storm events were correlated to increases in FIB (both EC and ENT) and increases in the amount of particles in suspension in the water column (39).

Evanson and Ambrose (68) examined a tidally influenced wetland in southern California and determined that although sediments were enriched in FIB, they were not a source to surfzone waters. Sediment and water FIB peaked in conjunction with rain events, but water FIB concentrations always declined quickly after the event whereas sedimentassociated FIB populations declined slowly. They concluded that at this location the sedimentary FIB populations likely have population dynamics independent of the water FIB population. Alternatively, other studies in similar systems in Southern California have shown that high concentrations of ENT (possibly stemming from abundant ENT populations identified in sediments, on vegetation, and from birds) in tidal saltwater marshes result in contamination of the surfzone water quality (75). This particular study noted that in the dry season, surfzone exceedences happen most frequently during the spring tides when tidal transport between the wetlands and surf zone is greatest.

The human health risks associated with ENT derived from wetland effluent are unclear. Although presumably different health risks are associated with ENT derived from nonhuman pollution, no epidemiological studies to date have addressed this issue. Some data from mesocosm studies, designed to evaluate efficiency of pathogen removal from wastewater in engineered wetlands, suggest that die-off rates of all bacteria and coliphage are greater in the water column than in the sediment, but that the protozoan pathogen Giardia has a greater die-off rate in the sediment than the water (76). These data were generated in an artificial environment, but the study illustrates the potential for sediments to differentially act as ecosystem sources or sinks depending on the microbe.

Temperate Great Lakes Beaches. Many studies at Great Lakes beaches have documented populations of FIB in sands at densities much higher than ambient water concentrations. Wet sands have cultivatable concentrations of ENT and EC that are 4-38 times higher and 3-17 times higher, respectively, than concentrations found in water ((65), Table 2). Mesocosm experiments with seeded EC in sterilized local sand show growth and persistence at even higher levels than those in the environment, indicating the probable importance of competition and predation in natural communities (77). Comparisons between wet (intertidal) and dry (foreshore) sands have revealed that dry sand harbors higher concentrations of EC than wet sand or ambient water; these sands are a source of EC to recreational waters in Lake Michigan and support an autochthonous, high density population of indicator bacteria for sustained periods independent of lake, human, or animal input (52). At Lake Superior, Ishii et al. (78) observed the highest densities of EC in nearshore sand and high but extremely patchy populations in far upshore sands; the abundance of EC in sediment, shoreline and nearshore sands increased as temperature increased over the course of the summer. Even throughout the northern Minnesota winter, EC strains were recoverable from sands and source-tracking was unable to connect these strains with known sources (78). Subsequently, in the summer these "naturalized" strains were frequently recovered from water, sand, and lake sediments, and were in highest relative abundance in August waters, providing further evidence of environmental populations of FIB (78). In a different study, multilocus enzyme electrophoresis and multilocus sequence typing of EC isolates from soils and sands at freshwater beaches on Lake Huron and the St. Clair river in Michigan revealed great genetic diversity overall, but several distinct 
genotypes were shared among sites and repeatedly recovered over time (79), which likewise supports the hypothesis of naturalized soil/sand FIB populations. Indeed, the temperate environment may be more hospitable for bacteria at the beach than originally believed; EC isolates have been shown to survive longer at lower temperatures than higher temperatures in soil from the watersheds of this region (80) and in colder temperatures of lake water (42).

Several studies have contextualized the relative contribution of different sources, including beach sands, to ambient water quality in the region. Results from Ishii et al. (78) found beach sands and humans were significant sources of FIB to recreational waters in spring and early summer, whereas the importance of waterfowl as a source of sand and water FIB increased in the late summer and early fall. Haack et al. (81) showed that beach orientation with respect to regional weather patterns such as wind speed and direction as well as regional and local hydrodynamics must be considered in understanding under what conditions beach sands may contribute FIB to local waters.

In addition to the evidence of naturalized populations of $\mathrm{EC}$, there is some evidence of human impact as well. Haack et al. (81) found ENT isolates with phenotypes similar to human pathogens from beach sands and waters at Grand Traverse Bay in Michigan as well as significant levels of antibiotic resistance. The majority of indicators are not pathogenic; of 3557 strains of EC isolated by Ishii et al. (78), only one could be classified as a potential human pathogen. Analysis of the potential risk of exposure to beach sands contaminated with high concentrations of EC (found at Chicago beaches) showed that after handling sand for $60 \mathrm{~s}$, the amount of EC transferred to the hand was correlated to the density of bacteria in the sand rather than the area of hand exposed (82). In this case, using dose-response estimates developed for swimming water contaminated by human sewage, it was determined that the number of individuals per thousand that would develop gastrointestinal symptoms would be 11 if all EC on the fingertip were ingested (82).

\section{Observations of Human Pathogens in Beach Sands}

Publication of the first beach sand epidemiological study (83) showed that "sand contact activities", including digging in sand or being buried in sand, were positively associated with enteric illness. This illustrated that for some populations, beach activities may be an overlooked route of exposure to certain pathogens.

To date, most studies investigating human pathogens in beach sands have either not sought or failed to identify a discernible relationship between abundance of indicators and pathogens in beach sands. There is some general evidence pathogens accumulate in sands and sediments. Enteric viruses have been documented at higher concentrations in estuarine sediments than in the water column (84). In freshwater sediment microcosm experiments, culturable EC and the pathogens Klebsiella pneumoniae and Pseudomonas aeruginosa all survived for weeks, though exhibiting linear decay rates (85). P. aeruginosa was isolated more frequently from beach sands than from water in Israel (86) and also has been isolated from tidally influenced beach sands in Portugal (87). Staphylococcus aureus has been found to be enriched in beach sands relative to local waters and $S$. aureus counts were correlated to the presence of yeasts of human origin as well as the number of swimmers on the beach at the time of sampling, implicating bathers as the source of this bacteria $(88,89)$. The beach sands along the Gaza Strip, an area of coastline that is heavily polluted with treated, partially treated, and untreated sewage, harbor higher concentrations of fecal indicators and higher concentrations of potentially patho- genic Salmonella and Vibrio isolates than local waters (90). The human pathogen Aeromonas hydrophila has been recovered along with pathogenic Vibrio spp. from sands along the Tel Aviv coast in the Mediterranean (86). Additionally, samples taken during a water quality exceedance event at a Florida beach impacted by nonpoint source pollution were positive for the pathogens $V$. vulnificius and the human Polyomavirus in both sand and water, while sand was exclusively positive for Cryptosporidium spp. and water exclusively positive for Giardia spp (91).; however, with only four sampling events, no significant relationship between indicators and pathogens could be identified.

A study conducted at bathing beaches in England documented pathogenic Campylobacter jejuni and Salmonella in beach sands, with Campylobacter having a higher rate of recovery from wet sand than dry sand (92). At a site receiving sewage effluent and agricultural runoff, campylobacteria and fecal indicators were elevated in surficial sediments but showed no relationship to one another (93). In Brazil, antibiotic resistance in potentially pathogenic ENT isolates has been more frequently observed in the sands of heavily polluted beaches than relatively pristine beaches, and in both cases more frequently in sands than waters (94). Recently, methicillinresistant Staphylococcus aureus (MRSA) has been isolated from beach sand and seawater in southern California (95) and in the state of Washington (96), fueling speculation that public beaches may be a previously overlooked environmental reservoir for the transmission of MRSA.

\section{Summary and Implications}

Although the scientific community has long known that diverse bacterial populations exist in beach sands (97) and recognized that soil and sediments may play a role in the survival of FIB in the environment $(14,50)$, it is only recently that the extent of anthropogenic impact at the beach and the possible public health repercussions have been realized. The studies analyzed in this review and especially those presented in Table 2 indicate dry sands that are infrequently wet, where people likely spend time sunbathing and picnicking, generally have the highest FIB concentrations at the beach, and that in comparison to water column bacterial measurements, intertidal sands are also enriched in FIB by an order of magnitude or more. Laboratory and field experiments in subtropical and temperate locales suggest sand rewetting may spur growth of indigenous FIB populations, and thus tidal or precipitation events may directly or indirectly contribute to fluctuations in sand bacterial concentrations. Data from nearly all environments suggest erosional flow conditions generated by storms or tides may flush bacteria out of sediments or sands, resulting in some level of contamination of the water column.

The relative health risk presented by enteric bacteria in sands remains largely unknown. Most epidemiological studies examining water quality at bathing beaches have not excluded bather exposure to sands. Studies that have explicitly tested exposure to sands either did not report FIB abundance (83), or used duration of exposure to sand and water rather than bacterial abundance to test the relationship with negative health outcomes (66). Testing whether there is a dose-dependent response between increasing abundance of FIB in recreational sands and negative health outcomes for beachgoers is necessary in order to understand what level of fecal bacteria in sands constitutes an unacceptable health risk. Furthermore, it would help to clarify whether fecal bacteria in the sand environment should be monitored at all. Although concentrations of FIB in sands seem excessive when normalized to water quality standards, it is important to remember 
the water quality standards are based on swimmer exposure to, and presumed ingestion of, water. Exposure to sand may be prolonged, but ingestion and other alternative routes of transmission require further study.

In regard to the impact bacteria in sands may have on water quality, the differences in epidemiological studies conducted at bathing beaches with point versus nonpoint source pollution (e.g., 2, 32, 33) suggest that health outcomes resulting from bathing in waters contaminated with human sewage would be different from that from bathing in waters contaminated with bacteria derived from persistent sand populations. Further studies at beaches experiencing varied sources of pollution are needed to determine the conditions when beach sands may be contributing a signal of water pollution via the resuspension of endogenous indicators. For example, based on flow conditions and standard hydrologic relations in a river, one can estimate how frequently sediments near a sewage outfall that are enriched in bacteria would be resuspended into the water (98). Models of sediment and sand resuspension at beaches (e.g., 99, 61) can further help to understand when these bacteria may impact water quality and may even contribute to "early warning" models (101).

However, without better characterizing the pathogens in beach sands, their distributions, and the environmental conditions in which they prosper, we cannot characterize the impact these populations may have on water quality or beachgoer health. Although many studies have documented the presence of viral, bacterial, and protistan pathogens in beach sands, we lack basic information about die-off rates, ability to persist, and growth rates of the organisms that may exploit sands or sediments. Collecting these data in a way that facilitates comparisons requires standardized methods of detection which should be experimentally determined and agreed upon by researchers. The recent study comparing methods (69) gives good reference for culture-based enumeration of FIB in medium to coarse sands from different environments. Similar comparisons of protocols for marsh sediment and fine-grain sands must be conducted, and might require more rigorous treatment to detach bacteria from sand grains. Likewise, as rapid molecular methods of FIB detection are standardized for water quality regulators, these methods will need to be optimized for the detection of FIB in beach sands. If qPCR is used, important questions for moving forward with sand samples will include basic issues related to PCR (see 101 and 102 for detailed review), as well as how much sample needs to be used for DNA extraction, how the recovery of sample DNA from the extraction protocol is estimated and whether to correct for this in the final cell estimation, how inhibition of PCR (which may be highly variable among samples) is handled, and what primer sets and standards should be used for the PCR assay. As with water quality samples, it will be important to determine how DNA-based estimates of cells correspond to risk-based analyses that have been based on culturable FIB in epidemiological studies.

In summary, further research into the introduction, distribution, and persistence of FIB and pathogens in beach sands, and the public health implications of these findings, is needed before any incorporation of beach sands into a monitoring framework should be considered. With millions of exposures to polluted sand and water every year, the economic burdens associated with negative health outcomes could be substantial (103). But while the relative risks are further explored by scientists and policy makers, there are some relatively low-cost responses that can be employed to better protect human health. Advocating easy preventive measures such as washing hands before eating at the beach, and protecting open wounds at the beach, may effectively reduce illness especially among the populations most vulnerable to opportunistic pathogens-the very young, the old, and those with compromised immune systems. Whitman et al. (82) showed that washing sandy hands effectively removed $92 \%$ of EC, which would greatly limit the handmouth transfer of bacteria. Likewise, maintaining the general sanitary condition of beach sands, through measures such as cleaning up dog feces and properly disposing of the human-generated garbage that may attract gulls or other animals, may help prevent illness until specific risks can be characterized with greater certainty.

\section{Acknowledgments}

This work was supported by the National Science Foundation under grant OCE-0430724, and the National Institute of Environmental Health Sciences P50ES012742. E.H. was partially supported by WHOI Academic Programs and grants from the WHOI Ocean Ventures Fund and the WHOI Coastal Ocean Institute.

\section{Supporting Information Available}

Table detailing experimental conditions for detection of FIB in sands. This material is available free of charge via the Internet at http://pubs.acs.org.

\section{Literature Cited}

(1) Shuval, H. Estimating the global burden of thalassogenic diseases: Human infectious diseases caused by wastewater pollution of the marine environment. J. Water Health 2003, 1 (2), 53-64.

(2) Haile, R. W.; Witte, J. S.; Gold, M.; Cressey, R.; McGee, C.; Millikan, R. C.; Glasser, A.; Harawa, N.; Ervin, C.; Harmon, P. The health effects of swimming in ocean water contaminated by storm drain runoff. Epidemiology 1999, 10 (4), 355-363.

(3) Wade, T. J.; Calderon, R. L.; Sams, E.; Beach, M.; Brenner, K. P.; Williams, A. H.; Dufour, A. P. Rapidly measured indicators of recreational water quality are predictive of swimming-associated gastrointestinal illness. Environ. Health Perspect. 2006 114 (1), 24-28.

(4) Prüss, A. Review of epidemiological studies on health effects from exposure to recreational water. Int. J. Epidemiol. 1998, 27 (1), 1-9.

(5) Wade, T. J.; Pai, N.; Eisenberg, J. N. S.; Colford, J. M. Do US Environmental Protection Agency water quality guidelines for recreational waters prevent gastrointestinal illness? A systematic review and meta-analysis. Environ. Health Perspect. 2003, 111 (8), 1102-1109.

(6) Boehm, A. B.; Fuhrman, J. A.; Mrse, R. D.; Grant, S. B. Tiered approach for identification of a human fecal pollution source at a recreational beach: Case study at Avalon Bay, Catalina Island, California. Environ. Sci. Technol. 2003, 37 (4), 673680.

(7) Bonadonna, L.; Briancesco, R.; Ottaviani, M.; Veschetti, E. Occurrence of Cryptosporidium oocysts in sewage effluents and correlation with microbial, chemical and physical water variables. Environ. Monit. Assess. 2002, 75 (3), 241-252.

(8) Gerba, C. P.; Goyal, S. M.; LaBelle, R. L.; Cech, I.; Bodgan, G. F. Failure of indicator bacteria to reflect the occurrence of enteroviruses in marine waters. Am. J. Public Health 1979, 69 (11), 1116-1119.

(9) Horman, A.; Rimhanen-Finne, R.; Maunula, L.; von Bonsdorff, C. H.; Torvela, N.; Heikinheimo, A.; Hanninen, M. L. Campylobacterspp., Giardiaspp., Cryptosporidium spp., noroviruses, and indicator organisms in surface water in southwestern Finland, 2000-2001. Appl. Environ. Microbiol. 2004, 70 (1), 87-95.

(10) Noble, R. T.; Fuhrman, J. A. Enteroviruses detected by reverse transcriptase polymerase chain reaction from the coastal waters of Santa Monica Bay, California: Low correlation to bacterial indicator levels. Hydrobiologia 2001, 460 (1), 175184.

(11) Pusch, D.; Oh, D. Y.; Wolf, S.; Dumke, R.; Schröter-Bobsin, U.; Höhne, M.; Röske, I.; Schreier, E. Detection of enteric viruses and bacterial indicators in German environmental waters. Arch. Virol. 2005, 150 (5), 929-947. 
(12) Standridge, J. H.; Delfino, J. J.; Kleppe, L. B.; Butler, R. Effect of waterfowl (Anas platyrhynchos) on indicator bacteria populations in a recreational lake Madison, Wisconsin. Appl. Environ. Microbiol. 1979, 38 (3), 547-550.

(13) Graczyk, T. K.; Majewska, A. C.; Schwab, K. J. The role of birds in dissemination of human waterborne enteropathogens. Trends Parasitol. 2008, 24 (2), 55-59.

(14) Whitman, R. L.; Shively, D. A.; Pawlik, H.; Nevers, M. B.; Byappanahalli, M. N. Occurrence of Escherichia coli and enterococci in Cladophora (Chlorophyta) in nearshore water and beach sand of Lake Michigan. Appl. Environ. Microbiol. 2003, 69 (8), 4714-4719.

(15) Van Donsel, D. J.; Geldreich, E. E.; Clarke, N. A. Seasonal variations in survival of indicator bacteria in soil and their contribution to storm-water pollution. Appl. Environ. Microbiol. 1967, 15 (6), 1362-1372.

(16) Alkan, U.; Elliott, D. J.; Evison, L. M. Survival of enteric bacteria in relation to simulated solar radiation and other environmental factors in marine waters. Water Res. 1995, 29, 20712080.

(17) Fujioka, R. S.; Hashimoto, H. H.; Siwak, E. B.; Young, R. H. Effect of sunlight on survival of indicator bacteria in seawater. Appl. Environ. Microbiol. 1981, 41 (3), 690-696.

(18) Sinton, L. W.; Finlay, R. K.; Lynch, P. A. Sunlight inactivation of fecal bacteriophages and bacteria in sewagepolluted seawater. Appl. Environ. Microbiol. 1999, 65 (8), 3605-3613.

(19) Whitman, R. L.; Nevers, M. B.; Korinek, G. C.; Byappanahalli, M. N. Solar and temporal effects on Escherichia coli concentration at a Lake Michigan swimming beach. Appl. Environ. Microbiol. 2004, 70 (7), 4276-4285.

(20) Boehm, A. B.; Grant, S. B.; Kim, J. H.; Mowbray, S. L.; McGee, C. D.; Clark, C. D.; Foley, D. M.; Wellman, D. E. Decadal and shorter period variability of surf-zone water quality at Huntington beach, California. Environ. Sci. Technol. 2002, 36, 38853892.

(21) Hartz, A.; Cuvelier, M.; Nowosielski, K.; Bonilla, T. D.; Green, M.; Esiobu, N.; McCorquodale, D. S.; Rogerson, A. Survival potential of Escherichia coli and enterococci in subtropical beach sand: Implications for water quality managers. J. Environ. Qual. 2008, 37 (3), 898-905.

(22) Mika, K. B.; Imamura, G.; Chang, C.; Conway, V.; Fernandez, G.; Griffith, J. F.; Kampalath, R. A.; Lee, C. M.; Lin, C. C.; Moreno, R. Pilot-and bench-scale testing of faecal indicator bacteria survival in marine beach sand near point sources. J. Appl. Microbiol. 2009, 107 (1), 72-84.

(23) Yamahara, K. M.; Walters, S. P.; Boehm, A. B. Growth of enterococci in unaltered, unseeded beach sands subjected to tidal wetting. Appl. Environ. Microbiol. 2009, 75 (6), 15171524.

(24) Feng, F.; Goto, D.; Yan, T. Effects of autochthonous microbial community on the die-off of fecal indicators in tropical beach sand. FEMS Microb. Ecol. 2010, 74 (10), 214-225.

(25) Hanes, N. B.; Fragala, R. Effect of seawater concentration on the survival of indicator bacteria. J. Water Pollut. Control Fed. 1967, 39, 97-104.

(26) Walters, S. P.; Yamahara, K. M.; Boehm, A. B. Persistence of nucleic acid markers of health-relevant organisms in seawater microcosms: Implications for their use in assessing risk in recreational waters. Water Res. 2009, 43, 4929-4939.

(27) Boehm, A. B.; Yamahara, K. M.; Love, D. C.; Peterson, B. M.; McNeill, K.; Nelson, K. L. Covariation and photoinactivation of traditional and novel indicator organisms and human viruses at a sewage-impacted marine beach. Environ. Sci. Technol. 2009, 43 (21), 8046-8052.

(28) Anderson, K. L.; Whitlock, J. E.; Harwood, V. J. Persistence and differential survival of fecal indicator bacteria in subtropical waters and sediments. Appl. Environ. Microbiol. 2005, 71 (6), 3041-3048.

(29) Cabelli, V. J.; Dufour, A. P.; Levin, M. A.; McCabe, L. J.; Haberman, P. W. Relationship of microbial indicators to health effects at marine bathing beaches. Am. J. Public Health 1979, 69 (7), 690-696.

(30) Cabelli, V. J.; Dufour, A. P.; McCabe, L. J.; Levin, M. Swimmingassociated gastroenteritis and water quality. Am. J. Epidemiol. 1982, 115 (4), 606-616.

(31) Calderon, R. L.; Mood, E. W.; Dufour, A. P. Health effects of swimmers and nonpoint sources of contaminated water. Int. J. Environ. Health Res. 1991, 1, 21-31.

(32) Colford, J. M.; Wade, T. J.; Schiff, K. C.; Wright, C. C.; Griffith, J. F.; Sandhu, S. K.; Burns, S.; Sobsey, M.; Lovelace, G.; Weisberg,
S. B. Water quality indicators and the risk of illness at beaches with nonpoint sources of fecal contamination. Epidemiology 2007, 18 (1), 27-35.

(33) Fleisher, J. M.; Fleming, L. E.; Solo-Gabriele, H. M.; Kish, J. K.; Sinigalliano, C. D.; Plano, L.; Elmir, S. M.; Wang, J. D.; Withum, K.; Shibata, T.; et al. The BEACHES Study: Health effects and exposures from non-point source microbial contaminants in subtrobical recreational marine waters. Intl. J. Epidemiol. 2010, Advance Access published June 3, 2010; doi:10.1093/ije/dyq084.

(34) National Resource Defense Council (NRDC). Testing the Waters 2009: A guide to water quality at vacation beaches. Available at http://www.nrdc.org/water/oceans/ttw/titinx. asp.

(35) Dziuban, E. J.; Liang, J. L.; Craun, G. F.; Hill, V.; Yu, P. A.; Painter, J.; Moore, M. R.; Calderon, R. L.; Roy, S. L.; Beach, M. J. Surveillance for waterborne disease and outbreaks associated with recreational water-United States, 2003-2004. MMWR Surveillance Summary 2006, 55 (12), 1-30.

(36) Huycke, M. M. Physiology of enterococci. In Enterococci: Pathogenesis, Molecular Biology and Antibiotic Resistance; Gilmore, M. S., Ed.; American Society for Microbiology: Washington, DC, 2002.

(37) Huysman, F.; Verstraete, W. Water-facilitated transport of bacteria in unsaturated soil columns: Influence of cell surface hydrophobicity and soil properties. Soil Biol. Biochem. 1993, 25 (1), 83-90.

(38) Zita, A.; Hermansson, M. Effects of bacterial cell surface structures and hydrophobicity on attachment to activated sludge flocs. Appl. Environ. Microbiol. 1997, 63 (3), 1168-1170.

(39) Fries, J. S.; Characklis, G. W.; Noble, R. T. Attachment of fecal indicator bacteria to particles in the Neuse River Estuary, NC. J. Environ. Eng. 2006, 132, 1338-1334.

(40) Byappanahalli, M.; Fujioka, R. Indigenous soil bacteria and low moisture may limit but allow faecal bacteria to multiply and become a minor population in tropical soils. Water Sci. Technol. 2004, 50 (1), 27-32.

(41) Gauthier, M. J.; Flatau, G. N.; Clement, R. L.; Munro, P. M. Sensitivity of Escherichia coli cells to seawater closely depends on their growth stage. J. Appl. Bacteriol. 1992, 73 (3), 257-262.

(42) Sampson, R. W.; Swiatnicki, S. A.; Osinga, V. L.; Supita, J. L.; McDermott, C. M.; Kleinheinz, G. T. Effects of temperature and sand on E. coli survival in a northern lake water microcosm. J. Water Health 2006, 4 (3), 389-394.

(43) Barcina, I.; Gonzalez, J. M.; Iriberri, J.; Egea, L. Survival strategy of E. coli and Enterococcus faecalis in illuminated fresh and marine systems. J. Appl. Bacteriol. 1990, 68, 189-198.

(44) Davies, C. M.; Evison, L. M. Sunlight and the survival of enteric bacteria in natural waters. J. Appl. Bacteriol. 1991, 70, 265274.

(45) Heim, S.; Del Mar Lleo, M.; Bonato, B.; Guzman, C. A.; Canepari, $P$. The viable but noncultable state and starvation are different stress responses of Enterococcus faecalis, as determined by proteome analysis. J. Bacteriol. 2002, 184 (23), 6739-6745.

(46) Lleo, M. D. M.; Tafi, M. C.; Canepari, P. Nonculturable Enterococcus faecalis cells are metabolically active and capable of resuming active growth. Syst. Appl. Microbiol. 1998, (21), 333-339.

(47) Lleo, M. D. M.; Signoretto, C. Canepari, P. Gram-Positive bacteria in the marine environment. In Oceans and Health: Pathogens in the Marine Environment; Colwell, R. R., Belkin, S., Eds.; Springer: New York, 2006.

(48) Pommepuy, M.; Butin, M.; Derrien, A.; Gourmelon, M.; Colwell, R. R.; Cormier, M. Retention of enteropathogenicity by viable but nonculturable Escherichia coli exposed to seawater and sunlight. Appl. Environ. Microbiol. 1996, 62 (12), 4621-4626.

(49) Smith, J. J.; Howington, J. P.; McFeters, G. A. Survival, physiological response and recovery of enteric bacteria exposed to a polar marine environment. Appl. Environ. Microbiol. 1994, 60 (8), 2977-2984.

(50) Gerba, C. P.; McLeod, J. S. Effect of sediments on the survival of Escherichia coli in marine waters. Appl. Environ. Microbiol. 1976, 32 (1), 114-120.

(51) Whitman, R. L.; Nevers, M. B. Foreshore sand as a source of Escherichia coli in nearshore water of a Lake Michigan beach. Appl. Environ. Microbiol. 2003, 69 (9), 5555-5562.

(52) Davies, C. M.; Long, J. A.; Donald, M.; Ashbolt, N. J. Survival of fecal microorganisms in marine and freshwater sediments. Appl. Environ. Microbiol. 1995, 61 (5), 1888-1896. 
(53) Priester, J. H.; Horst, A. M.; Van De Werfhorst, L. C.; Saleta, J. L.; Mertes, L. A. K.; Holden, P. A. Enhanced visualization of microbial biofilms by staining and environmental scanning electron microscopy. J. Microbiol. Meth. 2007, 68 (3), 577-587.

(54) Carrillo, M.; Estrada, E.; Hazen, T. C. Survival and enumeration of the fecal indicators Bifidobacterium adolescentis and Escherichia coli in a tropical rain forest watershed. Appl. Environ. Microbiol. 1985, 50 (2), 468-476.

(55) Rivera, S. C.; Hazen, T. C.; Toranzos, G. A. Isolation of fecal coliforms from pristine sites in a tropical rain forest. Appl. Environ. Microbiol. 1988, 54 (2), 513-517.

(56) Mundt, J. O. Occurrence of enterococci: Bud, bloom and soil studies. Appl. Microbiol. 1961, 9, 541-544.

(57) Anderson, S. A.; Turner, S. J.; Lewis, G. D. Enterococci in the New Zealand Environment: Implications for water quality monitoring. Water Sci. Technol. 1997, 35 (11-12), 325-331.

(58) Winfield, M. D.; Groisman, E. A. Role of nonhost environments in the lifestyles of Salmonella and Escherichia coli. Appl. Environ. Microbiol. 2003, 69 (7), 3687-3694.

(59) Boehm, A. B.; Sanders, B. F.; Winant, C. D. Cross-shelf transport at Huntington Beach. Implications for the fate of sewage discharged through an offshore ocean outfall. Environ. Sci. Technol. 2002, 36 (9), 1899-1906.

(60) Boehm, A. B.; Shellenbarger, G. G.; Paytan, A. Groundwater discharge: Potential association with fecal indicator bacteria in the surf zone. Environ. Sci. Technol. 2004, 38 (13), 35583566.

(61) Boehm, A. B.; Weisberg, S. B. Tidal forcing of enterococci at marine recreational beaches at fortnightly and semidiurnal frequencies. Environ. Sci. Technol. 2005, 39 (15), 5575-5583.

(62) Santoro, A. E.; Boehm, A. B. Frequent occurrence of the humanspecific Bacteroides fecal marker at an open coast marine beach: Relationship to waves, tides and traditional indicators. Environ. Microbiol. 2007, 9 (8), 2038-2049.

(63) Yamahara, K. M.; Layton, B. A.; Santoro, A. E.; Boehm, A. B. Beach sands along the California coast are diffuse sources of fecal bacteria to coastal waters. Environ. Sci. Technol. 2007, 41 (13), 4515-4521.

(64) Clark, C. D.; De Bruyn, W. J.; Jones, J. G. Photochemical production of hydrogen peroxide in size-fractionated Southern California coastal waters. Chemosphere 2009, 76, 141-146.

(65) Alm, E.; Burke, J.; Spain, A. Fecal indicator bacteria are abundant in wet sand at freshwater beaches. Water Res. 2003, 37 (16), 3978-3982.

(66) Bonilla, T. D.; Nowosielski, K.; Cuvelier, M.; Hartz, A.; Green, M.; Esiobu, N.; McCorquodale, D. S.; Fleisher, J. M.; Rogerson, A. Prevalence and distribution of fecal indicator organisms in South Florida beach sand and preliminary assessment of health effects associated with beach sand exposure. Mar. Pollut. Bull. 2007, 54 (9), 1472-1482.

(67) Desmarais, T. R.; Solo-Gabriele, H. M.; Palmer, C. J. Influence of soil on fecal indicator organisms in a tidally influenced subtropical environment. Appl. Environ. Microbiol. 2002, 68 (3), 1165-1172.

(68) Evanson, M.; Ambrose, R. F. Sources and growth dynamics of fecal indicator bacteria in a coastal wetland system and potential impacts to adjacent waters. Water Res. 2006, 40 (3), 475-486.

(69) Boehm, A. B.; Griffith, J.; McGee, C.; Edge, T. A.; Solo-Gabriele, H. M.; Whitman, R.; Cao, Y.; Getrich, M.; Jay, J. A.; Ferguson, D.; et al. Faecal indicator bacteria enumeration in beach sands. J. Appl. Microbiol. 2009, 107 (5), 1740-1750.

(70) Oshiro, R.; Fujioka, R. Sand, soil, and pigeon droppings: sources of indicator bacteria in the waters of Hanauma Bay, Oahu, Hawaii. Water Sci. Technol. 1995, 31 (5), 251-254.

(71) Shibata, T.; Solo-Gabriele, H. M.; Fleming, L. E.; Elmir, S. Monitoring marine recreational water quality using multiple microbial indicators in an urban tropical environment. Water Res. 2004, 38 (13), 3119-3131.

(72) Bonilla, T. D.; Nowosielski, K.; Esiobu, N.; McCorquodale, D. S.; Rogerson, A. Species assemblages of Enterococcus indicate potential sources of fecal bacteria at a south Florida recreational beach. Mar. Pollut. Bull. 2006, 52 (7), 807-810.

(73) Ferguson, D. M.; Moore, D. F.; Getrich, M. A.; Zhowandai, M. H. Enumeration and speciation of enterococci found in marine and intertidal sediments and coastal water in southern California. J. Appl. Microbiol. 2005, 99 (3), 598-608.

(74) Lee, C. M.; Lin, T. Y.; Lin, C. C.; Kohbodi, G. A.; Bhatt, A.; Lee, R.; Jay, J. A. Persistence of fecal indicator bacteria in Santa Monica Bay beach sediments. Water Res. 2006, 40 (14), 25932602 .
(75) Grant, S. B.; Sanders, B. F.; Boehm, A. B.; Redman, J. A.; Kim, J. H.; Mrse, R. D.; Chu, A. K.; Gouldin, M.; McGee, C. D.; Gardiner, N. A. Generation of enterococci bacteria in a coastal saltwater marsh and its impact on surf zone water quality. Environ. Sci. Technol. 2001, 35 (12), 2407-2416.

(76) Karim, M. R.; Manshadi, F. D.; Karpiscak, M. M.; Gerba, C. P. The persistence and removal of enteric pathogens in constructed wetlands. Water Res. 2004, 38 (7), 1831-1837.

(77) Alm, E. W.; Burke, J.; Hagan, E. Persistence and potential growth of the fecal indicator bacteria, Escherichia coli, in shoreline sand at Lake Huron. J. Great Lakes Res. 2006, 32 (2), 401-405.

(78) Ishii, S.; Hansen, D. L.; Hicks, R. E.; Sadowsky, M. J. Beach sand and sediments are temporal sinks and sources of Escherichia coli in Lake Superior. Environ. Sci. Technol. 2007, 41 (7), 2203-2209.

(79) Walk, S. T.; Alm, E. W.; Calhoun, L. M.; Mladonicky, J. M.; Whittam, T. S. Genetic diversity and population structure of Escherichia coli isolated from freshwater beaches. Environ. Microbiol. 2007, 8 (9), 2274-2288.

(80) Ishii, S.; Yan, T.; Shively, D. A.; Byappanahalli, M. N.; Whitman, R. L.; Sadowsky, M. J. Cladophora (Chlorophyta) spp. harbor human bacterial pathogens in nearshore water of Lake Michigan. Appl. Environ. Microbiol. 2006, 72 (7), 4545.

(81) Haack, S. K.; Fogarty, L. R.; Wright, C. Escherichia coli and Enterococci at beaches in the Grand Traverse Bay, Lake Michigan: Sources, characteristics, and environmental pathways. Environ. Sci. Technol. 2003, 37 (15), 3275-3282.

(82) Whitman, R. L.; Przybyla-Kelly, K.; Shively, D. A.; Nevers, M. B.; Byappanahalli, M. N. Hand-mouth transfer and potential for exposure to E. coli and F (+) coliphage in beach sand, Chicago, Illinois. J. Water Health 2009, 7 (4), 623-629.

(83) Heaney, C. D.; Sams, E.; Wing, S.; Marshall, S.; Brenner, K.; Dufour, A. P; Wade, T. J. Contact with beach sand among beachgoers and risk of illness. Am. J. Epidemiol. 2009, 170 (2), 164-172.

(84) LaBelle, R. L.; Gerba, C. P.; Goyal, S. M.; Melnick, J. L.; Cech, I.; Bogdan, G. F. Relationships between environmental factors, bacterial indicators, and the occurrence of enteric viruses in estuarine sediments. Appl. Environ. Microbiol. 1980, 39 (3), 588-596.

(85) Burton, G. A.; Gunnison, D.; Lanza, G. R. Survival of pathogenic bacteria in various freshwater sediments. Appl. Environ. Microbiol. 1987, 53 (4), 633-638.

(86) Ghinsberg, R. C.; Drasinover, V.; Sheinberg, Y.; Nitzan, Y. Seasonal distribution of Aeromonas hydrophila and Vibrio species in Mediterranean coastal water and beaches: a possible health hazard. Biomed. Lett. 1995, 51 (203), 151-159.

(87) Mendes, B.; Urbano, P.; Oliviera, J. S. Preliminary characterisation and proposal of microbiological quality standard of sand beaches. Water Sci. Technol. 1993, 35 (11-12), 147-150.

(88) Papadakis, J. A.; Mavridou, A.; Richardson, S. C.; Lampiri, M.; Marcelou, U. Bather-related microbial and yeast populations in sand and seawater. Water Res. 1997, 31 (4), 799-804.

(89) Charoenca, N.; Fujioka, R. S. Assessment of Staphylococcus bacteria in Hawaii's marine recreational waters. Water Sci. Technol. 1993, 27 (3/4), 24-30.

(90) Elmanama, A. A.; Fahd, M. I.; Afifi, S.; Abdallah, S.; Bahr, S. Microbiological beach sand quality in Gaza Strip in comparison to seawater quality. Environ. Res. 2005, 99 (1), 1-10.

(91) Abdelzaher, A. M.; Wright, M. E.; Ortega, C.; Solo-Gabriele, H. M.; Miller, G.; Elmir, S.; Newman, X.; Shih, P.; Alfredo Bonilla, J.; Bonilla, T.; et al. Presence of pathogens and indicator microbes at a non-point source subtropical recreational marine beach. Appl. Environ. Microbiol. 2010, 76 (3), 724-732.

(92) Bolton, F. J.; Surman, S. B.; Martin, K.; Wareing, D. R. A.; Humphrey, T. J. Presence of Campylobacter and Salmonella in sand from bathing beaches. Epidemiol. Inf. 1999, 122 (01), $7-13$.

(93) Obiri-Danso, K.; Jones, K. Intertidal sediments as reservoirs for hippurate negative campylobacters, salmonellae and faecal indicators in three EU recognised bathing waters in north west England. Water Res. 2000, 34 (2), 519-527.

(94) de Oliveira, A. J. F. C.; Pinhata, J. M. W. Antimicrobial resistance and species composition of Enterococcus spp. isolated from waters and sands of marine recreational beaches in Southeastern Brazil. Water Res. 2008, 42 (8-9), 2242-2250.

(95) Goodwin, K. D.; Pobuda, M. Performance of CHROMagarTM Staph aureus and CHROMagarTM MRSA for detection of 
Staphylococcus aureus in seawater and beach sand-Comparison of culture, agglutination, and molecular analyses. Water Res. 2009, 43 (19), 4802-4811.

(96) Soge, O. O.; Meschke, J. S.; No, D. B.; Roberts, M. C. Characterization of methicillin-resistant Staphylococcus aureus and methicillin-resistant coagulase-negative Staphylococcus spp. isolated from US West Coast public marine beaches. $J$. Antimicrob. Chemother. 2009, 64 (6), 1148-1155.

(97) Khiyama, H. M.; Makemson, J. C. Sand beach bacteria: Enumeration and characterization. Appl. Environ. Microbiol. 1973, 26 (3), 293-297.

(98) Irvine, K.; Pettibone, G. Dynamics of indicator bacteria populations in sediment and river water near contaminated sewer outfall. Environ. Technol. 1996, 14, 531-542.

(99) Bai, S.; Lung, W. S. Modeling sediment impact on the transport of fecal bacteria. Water Res. 2005, 39 (20), 5232-5240.

(100) Le Fevre, N. M.; Lewis, G. D. The role of resuspension in enterococci distribution in water at an urban beach. Water Sci. Technol. 2003, 47 (3), 205-210.
(101) Olyphant, G. A.; Thomas, J.; Whitman, R. L.; Harper, D. Characterization and statistical modeling of bacterial (Escherichia coli) outflows from watersheds that discharge into southern Lake Michigan. Environ. Monit. Assess. 2003, 81 (1), 289-300.

(102) Smith, C. J.; Osborn, A. M. Advantages and limitations of quantitative PCR (Q-PCR)-based approaches in microbial ecology. FEMS Microb. Ecol. 2009, 67 (1), 6-20.

(103) Sharma, S.; Radl, V.; Hai, B.; Kloos, K.; Mrkonjic Fuka, M.; Engel, M.; Schauss, K.; Schloter, M. Quantification of functional genes from prokaryotes in soil by PCR. J. Microbiol. Methods 2007, 68 (3), 445-452.

(104) Dwight, R. H.; Fernandez, L. M.; Baker, D. B.; Semenza, J. C.; Olson, B. H. Estimating the economic burden from illnesses associated with recreational coastal water pollution-A case study in Orange County, California. J. Environ. Manage. 2005, 76 (2), 95-103.

ES102747S 
Figure 1 originally excluded groundwater. Although contaminated groundwater can be a source of FIB to waters, it did not seem directly linked to pathways of FIB into and out of surficial beach sands. Since the publication of this review, it has been shown that through-beach transport of FIB to the groundwater table may be an important transport mechanism (e.g. Russell et al. 2012). As such, Figure 1 could be modified as follows: groundwater would be shown in two shades, the lighter shade representing fresh groundwater and the darker shade representing saline groundwater. $\mathbf{H}$ designates fresh groundwater as possible recipient of through-beach transport from e.g. (A, B, C or F). Groundwater discharge (H) thus represents an additional pathway of FIB from sands to coastal bathing water.

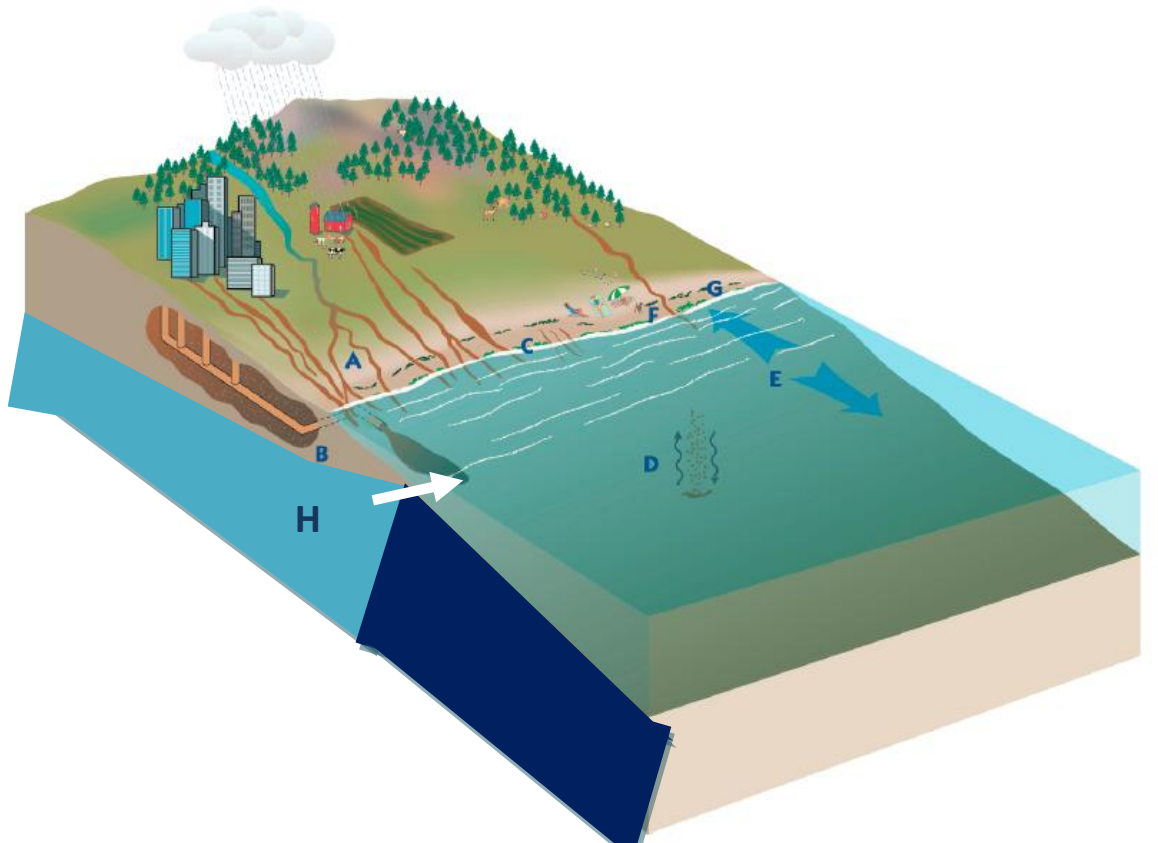

FIGURE 1. Pathways of fecal indicator bacteria (FIB) into and out of beach sands. (A) Runoff: Precipitation causes diffuse land-based runoff that concentrates FIB from urban areas (roadways, parking lots, gutters, lawns, pets), agriculture (overflow of animal waste), or feces from wildlife in the watershed into stormwater. Stormwater flows through local waterways or runs directly over beach sands into the intertidal zone. (B) Aging infrastructure: In urban areas with combined sewer overflows, heavy precipitation delivers a mix of urban runoff and raw sewage to beach sands and/or coastal waters, depending on outfall location and tidal stage. Leaky sewer infrastructure, failed septic systems, and buried drainage pipes in the coastal zone may also be sources of FIB to beach sands. (C) Swash zone: Periodic tidal rewetting enables FIB deposited in dry sands to persist or regrow, and waves may deliver FIB from the water column into the upper intertidal sands. (D) Exchange: Resuspension of sand into water by tidal or wind-driven waves may redistribute bacteria from sand to water; humans are then exposed to these bacteria when bathing. Likewise, deposition of particulate matter may introduce or return bacteria to the sand. Accretion of sands could bury FIB-rich sands at the beach, and erosion could alternately expose or relocate contaminated sands along the beach. (E) Water: Residence time of water at the beach may quickly remove or alternately retain bacteria near shore; thus, local hydrography and wind direction contribute to rates of removal or retention. (F) Fecal events: Animals (birds, dogs, wildlife, humans) on the beach may directly introduce FIB to sands, which can subsequently be redistributed over a greater area of beach by pedestrian traffic or weather events. (G) Additional refugia: Wrack, harboring robust bacterial populations seeded from land-based runoff or surfzone water, may shed FIB to sand or water during high tides. 
CHAPTER 3: Use of an exogenous plasmid standard and quantitative PCR to monitor spatial and temporal distribution of Enterococcus spp. in beach sands

Reprinted with permission from the American Society for Limnology and Oceanography 


\title{
Use of an exogenous plasmid standard and quantitative PCR to monitor spatial and temporal distribution of Enterococcus spp. in beach sands
}

\author{
Elizabeth Halliday', John F. Griffith ${ }^{2}$, and Rebecca J. Gast ${ }^{1}$ \\ ${ }^{1}$ Woods Hole Oceanographic Institution, Woods Hole, MA, USA \\ ${ }^{2}$ Southern California Coastal Water Research Project, Costa Mesa, CA, USA
}

\begin{abstract}
Studies using culture-dependent methods have indicated that enterococci, the fecal indicator used to monitor marine waters for the potential of enteric disease risk to swimmers, can be abundant in beach sands and may contribute to water column indicator exceedances. A quantitative PCR (qPCR) method for the Enterococcus genus was tested and applied to more rapidly determine the amount of enterococci in beach sands and study their distribution over space and time. The qPCR method amplified a 23S rDNA sequence specific to Enterococcus and was used to examine subsamples and composite samples of wet and dry beach sand from Avalon Bay, California, USA. The differences in efficiency of DNA recovery and inhibition in qPCR reactions were accounted for by spiking pairs of duplicate subsamples with a known amount of pGEM plasmid before or after extraction. This study revealed levels of environmental inhibition that were similar in wet and dry sands and efficiency of DNA recovery that was observably lower for wet beach sands and varied between years. Using the correction factors generated by this method to estimate the abundance of Enterococcus, we show that wet and dry beach sands both have Enterococcus spp. populations that can vary dramatically from day to day, and often are potentially higher than the equivalent health standards mandated for recreational waters.
\end{abstract}

Coastal managers in the US measure the microbiological quality of water by culturing fecal indicator bacteria (FIB), which are considered proxies for the possible presence of disease-causing pathogens. Epidemiological studies have shown that the density of enterococci in marine waters predicts relative risk of swimming-associated illness (Cabelli et al. 1979, 1982; Haile et al. 1999), and so Enterococcus spp. are monitored weekly during the bathing season as mandated by the federal government (USEPA 2000). Although it is well known that sands naturally accumulate cells and organic matter from the overlying water, the contribution of beach sands to ambient water quality is not well understood, and no FIB standards for beach sands exist. On lake beaches, sands have been shown to sustain pop-

*Corresponding author: E-mail: ehalliday@whoi.edu

\section{Acknowledgments}

This project is supported by grants from NSF (OCE-0430742) and NIEHS (P50ES012742) to the Woods Hole Center for Ocean and Human Health. Additional funding was provided by a grant from the California State Water Quality Control Board to the Southern California Coastal Water Research Project. Thanks to Kevan M. Yamahara and Alexandria B. Boehm, at Stanford University, for participating in the sand sample exchange.

DOI 10.4319/lom.2010.8.146 ulations of indicator bacteria and act as a diffuse nonpoint source of FIB to the lake (Whitman and Nevers 2003), indicating that sands may not act as a net sink for FIB as previously assumed. Along the California coast, Yamahara et al. (2007) showed that beaches are a diffuse source of FIB to marine water and that seawater can mobilize the loosely attached FIB from sands. Enterococci can also be resuspended by stream and storm water, thereby impacting beach water quality (Le Fevre and Lewis 2003). Furthermore, in the tropics, favorable nutrient concentrations and temperature within sediments allow fecal bacteria to multiply and become a minor population of the sediment microbiome (Roll and Fujioka 1997). Because the abundance of FIB, including those from humans, varies greatly in coastal waters spatially and temporally (Boehm et al. 2003; Boehm 2007), understanding the potentially dynamic relationship between sedimentary cells and the populations measured in the water column may further characterize the variation observed in fecal indicator bacteria in coastal waters.

Many of the studies that have recently addressed the microbial communities of marine recreational beach sands have used culture-based methods (e.g., Elmanama et al. 2005; Ferguson et al. 2005; Lee et al. 2006; de Oliveira et al. 2008). However, culture-based monitoring in beach sands may not adequately characterize populations of Enterococcus in sediments, 
because these methods exclude organisms that are dormant or in the viable but nonculturable state. Studies of the viability of $E$. faecalis in artificial seawater microcosms show that at least $80 \%$ of the cells are still viable when colony-forming units (CFUs) are no longer recoverable (del Mar Lleo et al. 2006). By using a molecular method, we seek to include viable but nonculturable organisms in our description of the Enterococcus spp. population in beach sands, although we recognize that by targeting DNA we will also detect dead cells.

Our primary objective in this study was the development of a flexible quantitative PCR method that can be used for rapid and sensitive quantification of microbes, including Enterococcus, in wet and dry beach sands. Expanding on a method developed by Coyne et al. (2005), we incorporated an external plasmid standard to estimate the efficiency of the DNA recovery process after extraction, as well as the impact of samplespecific inhibition of the qPCR assay; in doing this, we address and attempt to correct biases associated with a molecularbased method of detection. A further objective was the application of this method, using the sands of Avalon Bay, California, USA, as a case study, to describe the scale of significant spatial heterogeneity of the Enterococcus population in sands over time. By applying our method to individual subsamples and composite samples, we hope to guide future choices for sampling and compositing efforts.

The sands from the recreational beach at Avalon Bay, Catalina Island, California, were sampled for this study (Fig. 1). Avalon Bay has a history of bacteriological exceedances. The source of contamination is the deteriorated municipal sewer infrastructure at this location, and storm drains and storm water runoff are not considered to be major contributors to pollution (Boehm et al. 2003). In 2006, the year before this study's sampling regimen, waters at Avalon Bay violated public health standards $53 \%$ of the times sampled (Dorfman and Rosselot 2008), and in the summer of 2007, Avalon Bay had the worst dry-weather water quality in the entire state of California (Heal the Bay 2008).

\section{Materials and procedures}

Beach sand sampling-Sand samples were collected at 0800 on Thursdays, Fridays, Saturdays, and Sundays beginning on July 26 and ending on September 9, 2007, and at the same sites at 1200 on Fridays, Saturdays, and Sundays from August 1-31, 2008. One hundred sixty-two samples were collected in 2007, and 142 samples were collected in 2008. The beach sand was sampled above and below the water line at sites designated A, B, and C along the beach (see Fig. 1). Triplicate sand cores from wet sand, collected under approximately $10 \mathrm{~cm}$ water, and dry sands, collected from the high-tide line, were taken at each site. The sand was cored with sterile $50-\mathrm{mL}$ polypropylene Falcon tubes. Cores were flash-frozen in liquid nitrogen and shipped to the Woods Hole Oceanographic Institution, where they were subsequently stored at $-80^{\circ} \mathrm{C}$ until extraction. In California, the most probable number (MPN)

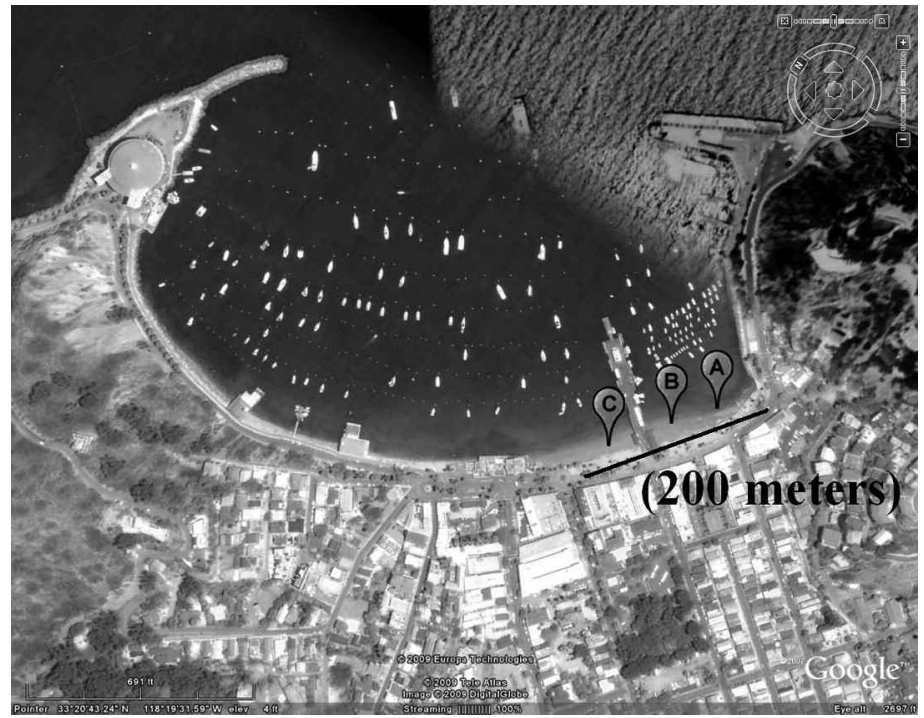

Fig. 1. Sampling sites at Avalon Bay $\left(33^{\circ} 20^{\prime} \mathrm{N}, 118^{\circ} 19^{\prime} \mathrm{W}\right)$, Catalina Island, CA, USA, shown aerially. Google Earth image.

method of Enterococcus detection, using Enterolert and 96-well Quantitrays (IDEXX), was used by the Southern California Coastal Water Research Program on sediments collected at the sites.

DNA extraction of environmental samples-Nucleic acids were extracted from $0.25 \mathrm{~g}$ sand using the MoBio PowerSoil DNA Kit (MoBio Laboratories). The subsamples selected for extraction were taken from the surface sand of the triplicate sand cores, which were then pooled before extraction. To generate a whole-beach composite sample, surface sand from the triplicates from all three sites along the beach was combined and $0.25 \mathrm{~g}$ removed for extraction.

Quantitative real-time PCR detection of Enterococcus-The Enterococcus assay uses the forward primer ECST748F (5'AGAAATTCCAAACGAACTTG) targeting enterococci, lactoCocci, and some clostridia and the reverse primer ENC854R (5'-CAGTGCTCTACCTCCATCATT), specific for the genus Enterococcus (Ludwig and Schliefer, 2000). qPCR reactions were run in triplicate for every environmental extract. Each $25-\mu \mathrm{L}$ reaction contained $1 \mu \mathrm{L}$ environmental template DNA, $100 \mathrm{ng}$ ECST748F, 100 ng ENC854R, $12.5 \mu \mathrm{L}$ SYBR Green Master Mix, and $9.5 \mu \mathrm{L}$ sterile MilliQ water. The cycling parameters began with a $95^{\circ} \mathrm{C}$ hold for $3 \mathrm{~min}$, then proceeded through 50 cycles of $95^{\circ} \mathrm{C}(10 \mathrm{~s}), 52^{\circ} \mathrm{C}(30 \mathrm{~s})$, and $72^{\circ} \mathrm{C}(10 \mathrm{~s})$, with real-time fluorescence detection enabled during extension. This was followed by additional denaturing $\left(95^{\circ} \mathrm{C}\right.$ for $\left.1 \mathrm{~min}\right)$ and incubation at $52^{\circ} \mathrm{C}(1 \mathrm{~min})$ to ensure that double-stranded product entered the melting curve cycle; the melting curve profile began at $52^{\circ} \mathrm{C}$ and ended at $95^{\circ} \mathrm{C}$, with a temperature change of $+0.5^{\circ} \mathrm{C}$ every $30 \mathrm{~s}$. The extension and annealing steps differ from the single anneal/extension step at $60^{\circ} \mathrm{C}$ used by Ludwig and Schliefer (2000) because of earlier optimization for product detection with regular PCR. Duplicate dilution series of 
purified E. faecalis DNA were used to construct the standard curve, and negative duplicates (reactions without template) were run on each plate. Standard curves were based on reactions with starting quantities of $1 \mathrm{ng}, 100 \mathrm{pg}, 10 \mathrm{pg}, 1 \mathrm{pg}, 100$ $\mathrm{fg}$, and $10 \mathrm{fg}$ E. faecalis DNA (Fig. 2A). The qPCR reactions were run with a Bio-Rad myIQ thermal cycler in plates sealed with optically clear flat caps. Plates were prepared on the bench or on ice for qPCR comparison as discussed below.

Melting curves were used as a quality control measure, with E. faecalis DNA having a melting point of $80.5^{\circ} \mathrm{C}$. Among triplicate qPCR reactions, occasionally there would be a reaction whose amplification was not exponential and whose melting curve did not conform to the profile. In these cases, the particular reaction was excluded from the analysis and the environmental sample quantified from the mean of two, rather than three, qPCR reactions.

Evaluating efficiency of DNA recovery and environmental inhibition-For samples collected on days representing the course of the summer sampling period (July 28, August 11, August 25, and September 8 in 2007 and August 2, 18, and 30 in 2008), an exogenous DNA standard (pGEM Vector, Promega) was added to the MoBio kit's initial extraction buffer (C1, an SDSbased lysis buffer) during the first step of the extraction. Extraction buffer $(500 \mu \mathrm{L})$ was prepared with $1 \mu \mathrm{g}$ pGEM plasmid, and $60 \mu \mathrm{L}$ was added to the 0.25 -g sand samples, which were then extracted according to kit directions. The amount of pGEM in the eluted DNA was subsequently quantified with qPCR. The pGEM plasmid primers M13F and pGEMR were used in triplicate qPCR reactions and compared to standard curves constructed with known amounts of pGEM (dilution series of $1 \mathrm{ng}$ to $10^{-5} \mathrm{ng}$ plasmid) to determine the recovery rates of pGEM from samples (Fig. 2B). Negative duplicate reactions lacking pGEM were run on each plate. The thermal cycler parameters began with a $95^{\circ} \mathrm{C}$ hold for $3 \mathrm{~min}$, then proceeded through 50 cycles of $95^{\circ} \mathrm{C}$ for $15 \mathrm{~s}$ and $60^{\circ} \mathrm{C}$ for $1 \mathrm{~min}$, followed by a melting cycle beginning at $60^{\circ} \mathrm{C}$ and ending at $95^{\circ} \mathrm{C}$, with a temperature change of $+0.5^{\circ} \mathrm{C}$ every $30 \mathrm{~s}$. From these samples, $100 \%$ recovery efficiency would be equivalent to recovery, via qPCR, of $1.2 \mathrm{ng}$ pGEM/ $\mu \mathrm{L}$ template (extraction product) DNA, and thus an average percentage of recovery from the extraction can be derived and used as the correction factor $E$, for efficiency of recovery.

This use of the vector as an exogenous reference standard expands on a method developed by Coyne et al. (2005) for qPCR detection of harmful algal bloom species in water samples but relies on SYBR green for target detection. Because $E$ is derived after extraction and qPCR analysis, it is affected by inhibition. Inhibitors present in the qPCR reaction may reduce enzyme activity or interact with DNA and thus prevent complete detection of the target, such that the correction factor $(E)$ is likely an underestimation of the true recovery of DNA through the extraction protocol.

To quantify the relative impact of inhibition and its variability in qPCR reactions, PCR reactions using eluted DNA of
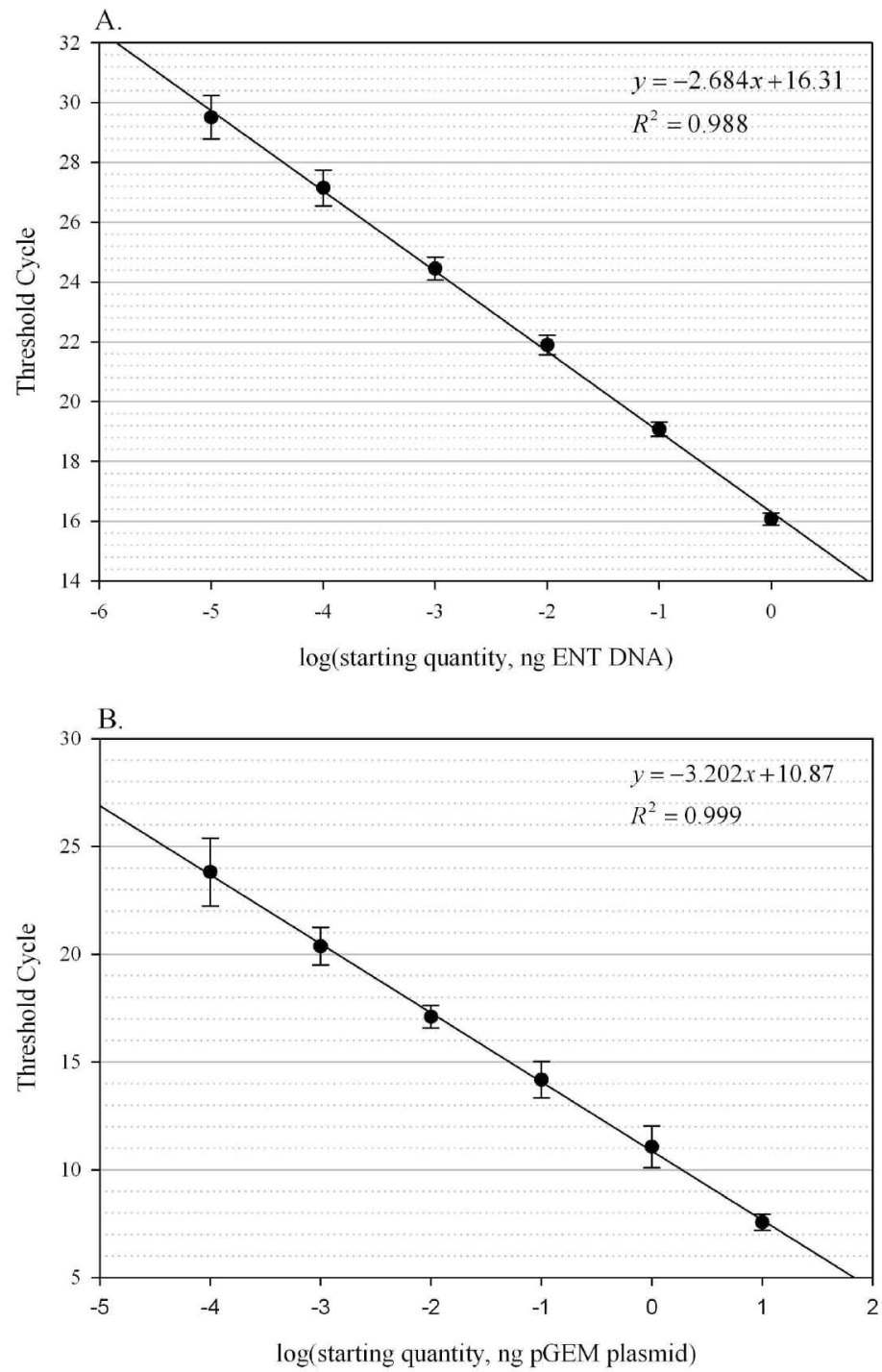

Fig. 2. $q P C R$ standard curve threshold cycles. E. faecalis standards (A) and $\mathrm{pGEM}$ standards (B). Error bars indicate SEM.

unspiked extracted duplicate samples had an equivalent amount of pGEM (1.2 ng pGEM/ $\mu \mathrm{L}$ extraction product) added to achieve the same idealized concentration as the samples coextracted with pGEM. Rate of pGEM recovery from these reactions via qPCR yielded an estimate of environmental inhibition. Thus a correction factor ( $I$ ) could be determined by the qPCR-reported starting quantity of pGEM in the reaction divided by the amount added to the reaction. This factor $I$ can be used to correct $E$, such that $(E / I)$ is a closer estimation of the recovery of DNA through the extraction protocol. We call this corrected efficiency of recovery $E_{c}$.

Estimation of Enterococcus cell density based on qPCR results-To calculate the total enterococcal DNA $\left(\mathrm{T}_{\mathrm{DNA}}\right)$ in 0.25 g sand, the starting quantity $\left(s_{q}\right)$ of Enterococcus DNA $(\mathrm{fg} / \mu \mathrm{L})$ reported by qPCR was multiplied by 100, to correct for the fact that only 1 of $100 \mu \mathrm{L}$ eluted DNA was quantified. This 
Table 1. Assessment of PGEM recovery and amplification.

\begin{tabular}{lcccc}
\hline & Average recovery & \multicolumn{2}{c}{ Average recovery } \\
Treatment & Sand type & on bench, $\%$ & $\boldsymbol{\sigma}$ & \multicolumn{1}{c}{ on ice, \% } \\
\hline pGEM spiked before extraction (efficiency) & Wet sand $(n=4)$ & 4.10 & 0.36 & 55.50 \\
& Dry sand $(n=4)$ & 13.3 & 1.31 & 5.3 \\
pGEM added to eluted DNA (inhibition) & All samples $(n=8)$ & 63.5 & 5.20 & 4.2 \\
\hline
\end{tabular}

adjusted reaction starting quantity was then corrected for inhibition of PCR $(I)$ and the corrected efficiency of DNA recovery by extraction protocol $\left(E_{c}\right)$. We were interested in individually quantifying $I$ and $E_{c^{\prime}}$, rather than simply observing total pGEM loss $(E)$, because of the potential variability of $I$ and $E_{c}$ in wet and dry sands in the environment and over time. Additionally, understanding the differences in loss due to the extraction protocol versus loss due to inhibition provides insight for further optimization and application of the protocol. The correction we used can be described as follows:

$$
\mathrm{T}_{\mathrm{DNA}}=\left[100 \times s_{q}\right] /\left(I \times E_{\mathrm{c}}\right)
$$

$\mathrm{T}_{\mathrm{DNA}}$ was converted to cell equivalents by dividing by the approximate DNA/enterococcal cell. The approximate amount of DNA per cell was calculated using the results of a completed E. faecalis genome sequence, which reports the cellular genome as 3,218,031 base pairs (Paulsen et al. 2003). The approximate base pairs per cell $(3.2 \mathrm{Mb})$ was multiplied by the average molecular weight of a nucleotide pair (660 Da), a Dalton being equivalent to $1 /\left(6.022 \times 10^{23}\right)$ grams, yielding about $3.5 \times 10^{-15} \mathrm{~g} \mathrm{DNA} /$ cell.

Sand extract exchange-Extracted DNA samples were exchanged with the Boehm laboratory at Stanford for comparison of our method of quantification with the method of Yamahara et al. (2009), which accounts for reaction inhibition by spiking with target DNA and uses the same primers (Ludwig and Scheifer 2000) with a TaqMan probe for qPCR detection. Two extracts were obtained from Yamahara and four extracts were sent from our lab. Yamahara ran our extracts as described in Yamahara et al. (2009), and we ran their extracts with our method.

Statistical analysis-Because the data are not normally distributed, but are similarly distributed between sites (skewed right), nonparametric statistical tests (Kruskal-Wallis, MannWhitney, and the Wilcoxon signed-rank test) were chosen for data analysis, using $P=0.05$ for the $\alpha$-level of significance. All statistics were calculated with SigmaPlot 11.

\section{Assessment}

Reliability of pGEM as a measurement of efficiency of DNA recovery and PCR inhibition-The effect of temperature during plate preparation was evaluated. The abundances of pGEM and Enterococcus in sand samples were quantified by qPCR using plates that were prepared at room temperature and on ice. For pGEM, a clear difference was observed in the efficiency of recovery for wet sand in comparison to dry sand, with dry sand having about $10 \%$ better extraction efficiency than wet sand (Table 1). However, preparing the plates on ice yielded substantially less-inhibited PCR reactions (Table 1 ). The environmental inhibition did not significantly differ between wet and dry sand. When the plates were set up in a similar manner for Enterococcus quantification, similar results were observed; that is, significantly more enterococcal DNA was detected when the plate had been prepared on ice, indicated by Wilcoxon signed-rank test for correlated samples ( $W=36$, $n=8, Z$ statistic $=2.521, P=0.008)$. However, by using the pGEM efficiency and inhibition correction factors appropriate to experimental conditions to calculate cell equivalencies from the DNA recovered, we arrived at similar cell equivalencies for each sample. The Wilcoxon signed-rank test showed no significant difference between cell equivalencies from the different treatments after correction $(W=-2.0, n=8, Z$ statistic $=-0.140, P=0.945)$. These results indicated that pGEM accurately reflected PCR reaction conditions, that extraction efficiency is consistently different for wet and dry sands, and that PCR inhibition is relatively constant in these beach sands over time. This result may not apply to all environmental matrices, but increased our confidence in the use of pGEM as a standard for this system.

Reliability of the standard curve and error associated with environmental samples-Over the course of many individual runs $(n>20)$, the standard curve dilution series of both pGEM and E. faecalis DNA amplified consistently, and each dilution had low standard error in threshold cycle (Fig. 2). We noted that as the amount of $E$. faecalis DNA in the qPCR reaction decreased, the standard deviation between qPCR replicates increased. Our environmental samples, which usually fell near the low end of our standard curve dilution series (femtograms), also reflect this observation. Maximizing the amount of starting quantity DNA, and maximizing the reaction efficiency, therefore minimizes the error associated with regression on the standard curve.

Composite versus grab and pooled sampling at Avalon Bay Beach in 2007-Duplicate whole-beach composite subsamples that were extracted for the pGEM experiments were compared to an average daily value calculated from sites A, B, and C. Additionally, on August 11 and September 8, subsamples from each of the triplicate samples from site $C$ were extracted and analyzed to determine the variability within a pooled triplicate site sample. Results indicated a high level of reproducibility between composite samples. The Wilcoxon signed-rank test showed no significant difference between the amount of 


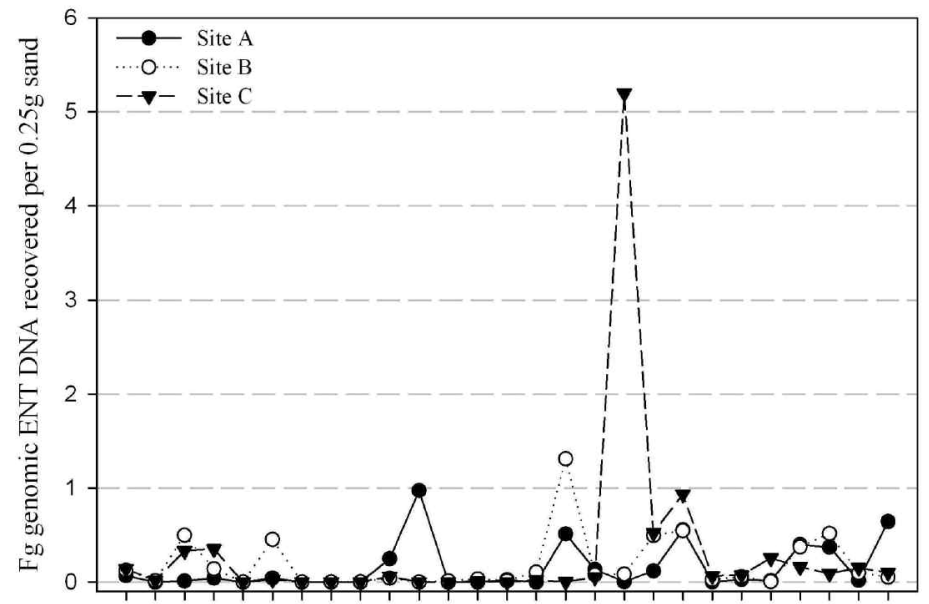

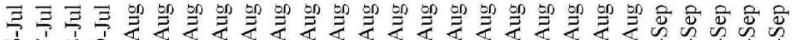

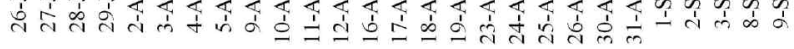

Summer 2007

Fig. 3. Recovery of Enterococcus spp. DNA in wet sand at Avalon Bay sampling sites.

Enterococcus at sites when calculated by averaging triplicate values or by composite sampling ( $W=-2.0, n=4$, Wilcoxon sign-ranked $Z$ statistic $=-0.365, P=0.875)$.

Spatial differences in Enterococcus in wet sand at Avalon Bay Beach-The pooled triplicates for wet sites A, B, and C were extracted and quantified for every day of the study, and the amount of Enterococcus in wet sand by site is shown in Fig. 3. Although sites did show some individual variation over the summer, no significant difference was observed in the average amount of Enterococcus between sites A, B, and C (Kruskal-Wallis test, $H=1.029$, $\mathrm{df}=2, P=0.598$ ).

Wet sands compared to dry sands-For samples collected in 2007, the daily amount of Enterococcus in wet sand was estimated by averaging the site values, and because no significant differences were observed spatially, the daily amount of Enterococcus in dry sand was measured from whole-beach composite samples. In 2008, all samples were whole-beach composites. In 2007, the wet sand daily averages showed distinct peaks in the amount Enterococcus DNA recovered, which occurred roughly every 2 weeks over the entire course of the summer (Fig. 4). In the dry sands, there were consistently low levels of enterococci until August 11. The amount of Enterococcus DNA recovered from the dry sand exceeded the amount of Enterococcus DNA in the wet sand for the rest of the summer.

The conversion of DNA to cell equivalents (Fig. 5) highlights the importance of measuring the difference in efficiency of recovery, because a slightly different, and interesting, pattern emerges. For example, some local maximums in dry sand Enterococcus DNA are, after correction, no longer so different from the wet sand (e.g., 215 cells and 243 cells in wet and dry sand, respectively, on September 2). Most interestingly, the biggest spike recorded for the summer in the wet sands (1935 cells/0.25 g on August 24) was followed by a precipitous

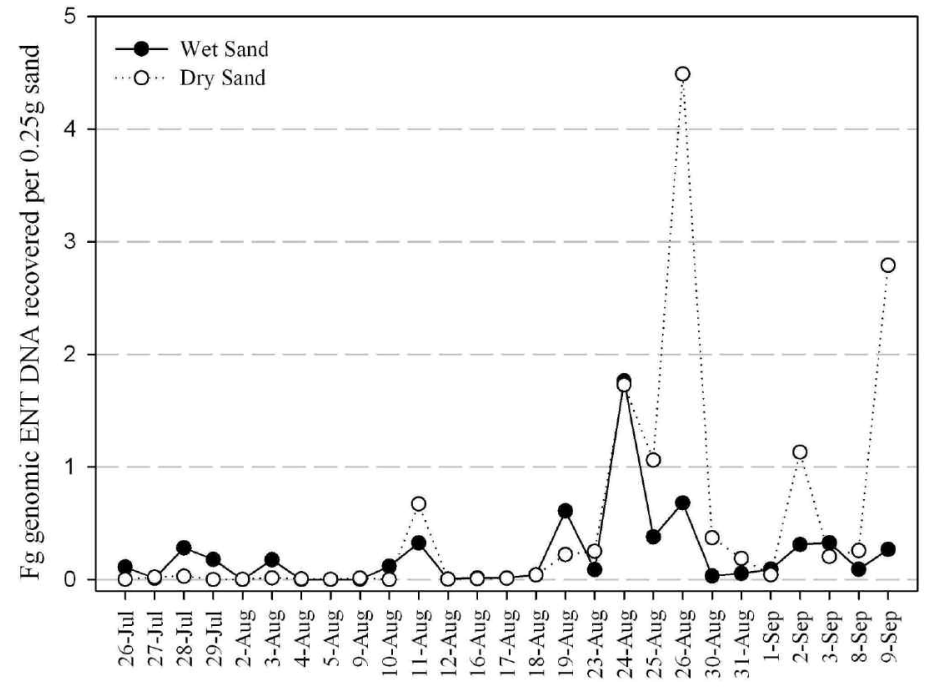

Summer 2007

Fig. 4. Enterococcus spp. DNA recovered from Avalon Bay beach sand.

decrease in the Enterococcus population in the wet sand, and only 2 days later we observed the summer peak for dry sands (1519 cells/0.25 g on August 26). We saw a similar pattern again in 2008 (Fig. 6), when a tremendous spike was observed in the enterococcal population of the wet sand on August 29, followed the next day by a precipitous decline of cells in the wet sand and corresponding increase of cells in the dry sand. Over the entire 2007 sampling period ( $n=27$ days) wet sand had a higher, though not significantly higher, total amount of enterococci than dry sand (Mann-Whitney test, $U=268.5, P=$ 0.098). In 2008, there was no significant difference in the amount of Enterococcus in the wet and dry sands (Mann-Whitney test, $U=90, P=0.730$ ), although the wet sand had the highest numbers recorded all summer on August 15 and 17.

Tidal impact-All of the daily composite dry sand samples and the daily average wet sand samples were ranked by amount of Enterococcus DNA recovered. One significant tidally associated difference emerged, in that the average rank of samples taken in 2007 on days when the tide was high (sampled within $1.5 \mathrm{~h}$ before and after true high tide, $n=18$ ) were of higher ranking than the average of samples taken on days when the tide was at a low or flood stage $(n=36$; Mann-Whitney test, $U=$ 213.0, $P=0.043$ ). A similar analysis for 2008 was untenable because overall there were fewer data points, and all samples were taken during the ebb or flood tide and none at the high or low tide marks. However, it is worth noting that in 2008, the largest peak in enterococci concentration in the wet sand occurred during the spring tidal period (August 15, 16; full moon in 2008 on August 16, new moon on August 1 and 30). Likewise, in 2007 the peaks in enterococci occur during spring tidal periods, directly before new (August 12, September 11) and full (July 30, August 28) moons. This is purely observational, as there were no statistically significant correlations between the 


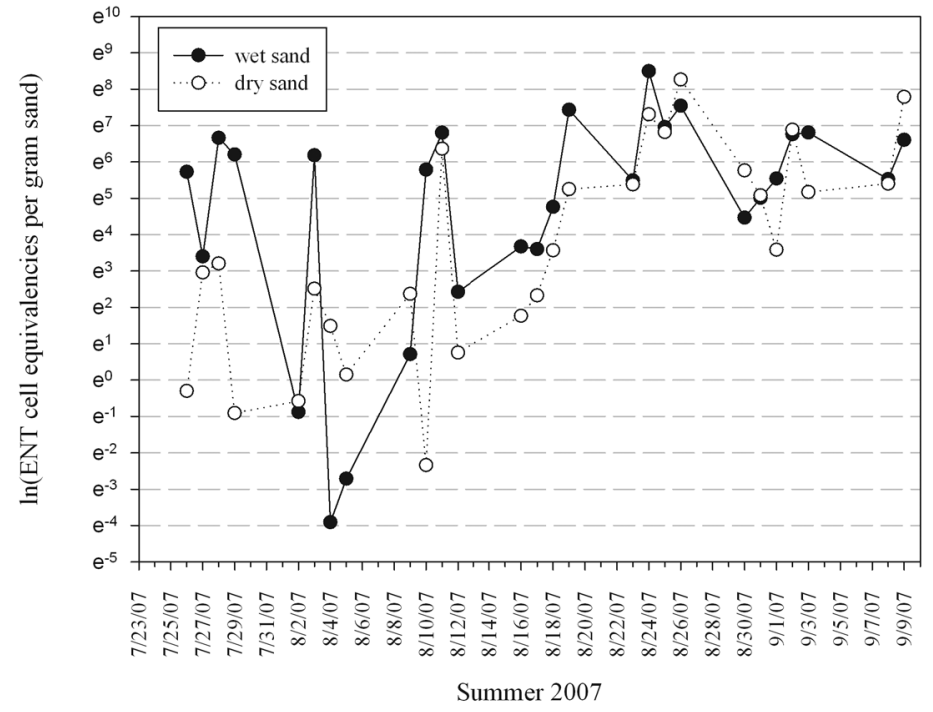

Fig. 5. Enterococcus spp. in Avalon Bay beach sand, 2007.

amount of enterococci in the sand and the tidal range of that day or with the height of the water when sampled.

Discrepancy in detection of Enterococcus via qPCR versus $M P N$ - In the 2007 data, there was no correlation between the number of cells detected using qPCR and the number of cells detected from the sediments using MPN. The wet sand MPN measurements taken at sites $\mathrm{A}, \mathrm{B}$, and $\mathrm{C}$ collectively averaged 3.1 cells/g and ranged from 0 to 42 cells, whereas all the wet sand qPCR measurements had an average detection of 612 cells/g, with a range of $1-4880$ cells/gram. There was some agreement between peaks in both data sets (peaks around August 11/12 and September 8/9). The ratio of the averages for MPN versus qPCR in this study is 0.005 , which is on the lower end of those reported by other studies (Yamahara et al. 2009; Haugland et al. 2005; He and Jiang 2005).

Sand extract exchange-To test the difference between our qPCR method and an alternative, that of Yamahara et al. (2009), we exchanged a total of six extracted samples (two from Yamahara, four from Halliday). The results are given in Table 2. Whereas our method consistently estimated the number of enterococci as higher, there was a clear relationship between our two methods of quantification for the Avalon samples exchanged (Fig. 7). Considering the potential difference in sensitivity of the two methods (TaqMan versus SYBR), different machines, and different personnel, the similarity between the results seems to be quite good. Furthermore, the standard deviation of the results generated with the different methods were within the range that we observe when comparing the results of different cycler runs for the same samples (between 20 and 60 cell equivalents), with the exception of one sample for which we had a very high result. If the highest outlier was removed from each comparison, then the average standard deviation between detection methods would be

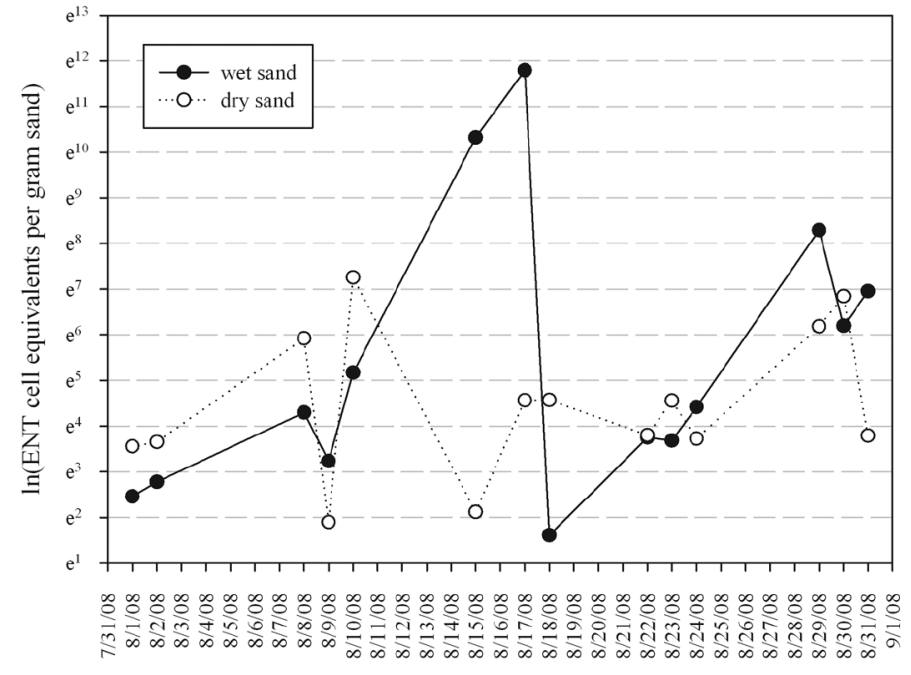

Summer 2008

Fig. 6. Enterococcus spp. in Avalon Bay beach sand, 2008.

reduced from 49.6 to 23.0 cell equivalents, and the average standard deviation between two different runs would be reduced from 30.6 to 25.5 cell equivalents.

\section{Discussion}

Efficiency of DNA recovery and inhibition of PCR are two biases that can differ between sample type and potentially skew quantitative PCR results. In this study, the pGEM plasmid proved to be a reliable way to characterize these biases and correct for them, and to reconcile differences in the methods different investigators may use in qPCR plate preparation.

There are multiple examples of different approaches that have been applied to account for inhibition in quantitative PCR. They generally use either nontarget DNA or some version of the target sequence as the mechanism to judge whether inhibition is occurring in the samples. We limit our comparison to several that have been used for the detection of indicator organisms in natural samples (Lebuhn et al. 2004, Siefring et al. 2008; Shanks et al. 2009; Yamahara et al. 2009). Yamahara et al., Shanks et al., and Lebuhn et al. all employ some aspect of the desired target sequence as the internal control, which is considered more likely to reflect the same amplification biases as the actual target. Shanks et al. (2009) took the innovative approach of creating an artificial sequence of a similar size to the target that contained the same primer sites, but a different TaqMan probe target. In the case of Lebuhn et al. (2004), samples were spiked before extraction with known numbers of the cell type being detected. Yamahara et al. (2009) directly spiked their qPCR reactions with genomic DNA from their target organism. They also determined the extraction efficiencies for their samples by spiking with a known number of enterococci, and then correcting the qPCR values for inhibition. Siefring et al. (2008) have taken probably the 
Table 2. Sand sample exchange qPCR data, presented in units of ENT cells/uL.

\begin{tabular}{lccc}
\hline Sample & Yamahara method & Present method & $\sigma$ \\
\hline 092807-EX-1 & 31.6 & 91.5 & 42.4 \\
102807-EX-1 & 11.2 & 48.3 & 26.2 \\
A080407DG & 7.4 & 36.1 & 20.3 \\
A080407WG & 10.0 & 52.5 & 30.1 \\
A082607DG & 19.8 & 137.3 & 83.1 \\
A082607WG & 32.1 & 467.8 & 308.1 \\
\hline
\end{tabular}

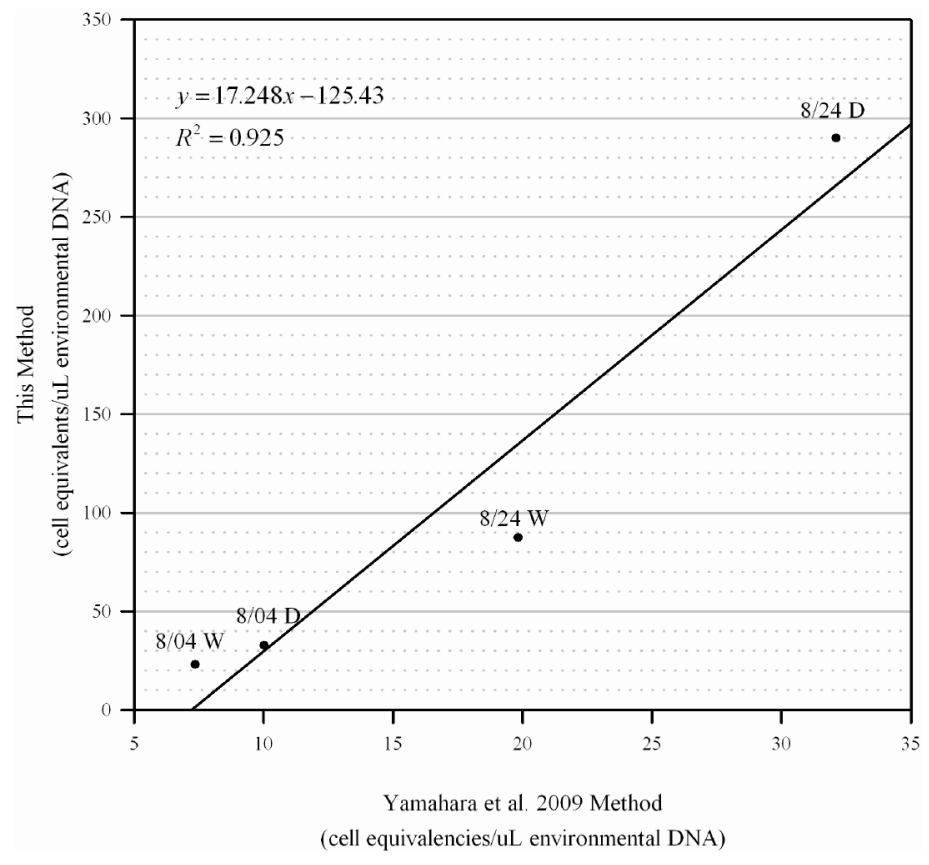

Fig. 7. Results of sand DNA exchange of Avalon Beach samples. W, wet sand; D, dry sand samples.

most effective steps toward developing an extraction and inhibition standard for enterococcal qPCR. They have redesigned the forward primer for the Enterococcus TaqMan assay and designed a Lactococcus-specific probe within that region. This allows the simultaneous detection of enterococci and correction for extraction efficiency and PCR inhibition by spiking with Lactococcus organisms. The fact that the amplification region is the same for both the control and the target significantly reduces the effect of amplification bias for different fragments.

These methods have all taken different, but valid, approaches to deal with some of the inherent problems associated with qPCR. We believe that our approach also is valid, although there is the potential problem that the pGEM target would not reflect the same amplification efficiency as the target. In an effort to assess whether this was a problem, we participated in the small sample exchange with Yamahara. Although our values tended to be higher, the standard deviation between Yamahara's method results and ours was within the standard deviation we observed for our method on different cycler runs of the same samples. Although we are unable to say whether our method is equivalent to the others, we believe that this information does tell us that our method of correcting for DNA recovery and PCR inhibition is likely to have no more of an impact on estimation error than other issues associated with qPCR variation. These other issues include sample degradation due to multiple freeze/thaws, variability in pipetting accuracy, and variability between and within qPCR machines. There is also the fact that we are using SYBR detection rather than the TaqMan probe method of Yamahara, which could contribute to our method giving slightly different values. At this point, we don't have an absolute answer as to why our results differed in the sample exchange, but this is one of the first examples of such a comparison. We will continue to explore the reasons behind the difference, but based on the fact that there is apparently an inherent level of variability for qPCR, we argue that in our hands PGEM has been an appropriate and flexible method for estimating and correcting for DNA recovery and PCR inhibition of environmental samples.

The results of this study show that beach sands have significant Enterococcus spp. populations that are patchy spatially and temporally and appear to be influenced by tidal stage. Although the wet sands at Avalon Bay had, overall, higher levels of enterococci, it is interesting to note that the sampling days that took place during higher tidal stages also had higher amounts of enterococci. At a beach like the one at Avalon Bay, which is narrow and does not have a large tidal range, this observation of wet and dry sand taken at higher tidal stages having more enterococci may correspond to common reports of dry beach sands having elevated levels of enterococci, because the sands sampled at high tide represent overall "drier" sands over the course of a day than the sands sampled at low tide. Yamahara et al. (2009) also showed that wetted sands in mesocosm experiments showed an initial decrease in enterococci numbers, but that over time, the numbers increased due to regrowth. The increase in enterococcal abundance in the dry sand over time at Avalon Bay suggests that after tidal wetting, the environmental populations may have regrown.

We have also shown that at Avalon Bay composite samples effectively integrated spatial variability, thereby giving a good estimate of Enterococcus prevalence in the sand from day to day. The fact that no significant variability was observed in the Enterococcus spp. populations between the three sites may be due to the fact that Avalon Bay is a small beach, making it ideal for composite sampling. This is valuable information because whenever composite samples can be analyzed in lieu of multiple site samples, costs of supplies and time associated with molecular monitoring are drastically reduced.

When our data are converted to equivalent monitoring volumes and analyzed for bacteriological compliance (using the current health standard of $104 \mathrm{CFU} / 100 \mathrm{~mL}$ for marine waters, and assuming one cell is equivalent to one CFU and that 
$1 \mathrm{~g}=1 \mathrm{~mL}$ ), the sand would rarely be in compliance with the health standard. Only 1 day (August 2, 2007) had compliance in both wet and dry sand; there were two other days when the wet sand would have been in compliance and three other days when the dry sand would have been in compliance. In contrast, many days would exceed the water health standard by several orders of magnitude. Perhaps the discrepancy between CFU detection and DNA-based detection can partially be explained by the large amounts of silicate minerals normally found in beach sand, which concentrate DNA from the overlying seawater (Naviaux et al. 2005). Environmental enterococcal DNA and dead cells also likely contribute a background signal in our monitoring. Further research is needed to understand the relative contributions of active, viable but nonculturable, and dead cells and environmental DNA in the beach sand environment. The presence of viable but nonculturable indicator organisms in sediments could be a significant part of this population, and therefore the degree to which they are indicative of health risk, as well as the conditions that may resuscitate them in the environment, are both questions worthy of further investigation.

From a human health perspective, the sanitary quality of beach sand may be important because beach sand is a common interface of interaction between beachgoers and the marine environment. FIB in beach sands may or may not be correlated to human pathogen presence in sands, but our data suggest that monitoring programs designed to protect human health, as well as studies analyzing the fate and transport of FIB in coastal waters, should consider the potential role of sedimentary Enterococcus spp. populations.

\section{References}

Boehm, A. B. 2007. Enterococci concentrations in diverse coastal environments exhibit extreme variability. Environ. Sci. Technol. 41:8227-8232 [doi:10.1021/es071807v].

-, J. A. Fuhrman, R. D. Morse, and S. B. Grant. 2003. A tiered approach for identification of a human fecal pollution source at a recreational beach: Case study at Avalon Bay, Catalina Island, California, USA. Environ. Sci. Technol. 37:673-680 [doi:10.1021/es025934x].

Cabelli, V. J., A. P. Dufour, M. A. Levin,, L. J. McCabe, and P. W. Haberman. 1979. Relationship of microbial indicators to health effects at marine bathing beaches. Am. J. Public Health 69:690-696 [doi:10.2105/AJPH.69.7.690].

—, - L. J. McCabe, and M. A. Levin. 1982. Swimming-associated gastroenteritis and water quality. Am. J. Epidemiol. 115:606-616.

Coyne, K. J., and others. 2005. Improved quantitative realtime PCR assays for enumeration of harmful algal species in field samples using an exogenous DNA reference standard. Limnol. Oceanogr. Methods 3:381-391.

del Mar Lleo, M., C. Signoretto and P. Canepari. 2006. Gram positive bacteria in the marine environment, p. 307-330. In S. Belkin and R. Colwell [eds.], Oceans and human health: Pathogens in the marine environment. Springer Science.

de Oliveira, A.J.F.C., and J. M. W. Pinhata. 2008. Antimicrobial resistance and species composition of Enterococcus spp. isolated from waters and sands of marine recreational beaches in Southeastern Brazil. Water Res. 42:2242-2250 [doi:10.1016/j.watres.2007.12.002].

Dorfman, M., and Rosselot, K. S. 2008. Testing the waters: A guide to water quality at vacation beaches, 18 th ed. $<$ http://www.nrdc.org/water/oceans/ttw/titinx.asp>. A Natural Resources Defense Council report.

Elmanama, A. A., M. I. Fahd, S. Affi, S. Abdallah and S. Bahr. 2005. Microbiological beach sand quality in Gaza Strip in comparison to seawater quality. Environ. Res. 99:1-10 [doi:10.1016/j.envres.2004.12.014].

Ferguson, D. M., D. F. Moore, M. A. Getrich, and M. H. Zhowandai. 2005. Enumeration and speciation of enterococci found in marine and intertidal sediments and coastal water in southern California. J. Appl. Microbiol. 99:598-608 [doi:10.1111/j. 1365-2672.2005.02660.x].

Haile, R. W., and others. 1999. The health effects of swimming in ocean water contaminated by storm drain runoff. Epidemiology 10:355-363 [doi:10.1097/00001648-19990700000004].

Haugland, R.A., S.C. Siefring, L.J. Wymer, K.P. Brenner, and A.P. Dufour. 2005. Comparison of Enterococcus measurements in freshwater at two recreational beaches by quantitative polymerase chain reaction and membrane filter culture analysis. Water Res. 39:559-568 [doi:10.1016/j.watres.2004.11.011].

He, J.-W., and S. Jiang. 2005. Quantification of enterococci and human adenoviruses in environmental samples by real-time PCR. Appl. Environ. Microbiol. 71:2250-2255 [doi:10.1128/AEM.71.5.2250-2255.2005].

Heal the Bay. 2008. 18th Annual Beach Report Card for 20072008. http://www.healthebay.org/brcv2 (Accessed February 26, 2010).

Le Fevre, N. M., and G. D. Lewis. 2003. The role of resuspension in enterococci distribution in water at an urban beach. Water Sci. Technol. 47:205-210.

Lebuhn, M., M. Effenberger, G. Garcés, A. Gronauer, and P. A. Wilderer. 2004. Evaluating real-time PCR for the quantification of distinct pathogens and indicator organisms in environmental samples. Water Sci. Technol. 50:263-270.

Lee, C. M., T. Y. Lin, C. Lin, G. A. Kohbodi, A. Bhatt, R. Lee, and J. A. Jay. 2006. Persistence of fecal indicator bacteria in Santa Monica Bay beach sediments. Water Res. 40:25932602 [doi:10.1016/j.watres.2006.04.032].

Ludwig, W., and K. H. Schliefer. 2000. How quantitative is quantitative PCR with respect to cell counts? Syst. Appl. Microbiol. 23:556-562.

Naviaux, R. K., B. Good, J. D. McPherson, D. L. Steffen, D. Markusic, B. Ransom and J. Corbeil. 2005. Sand DNA: a genetic library of life at the water's edge. Mar. Ecol. Prog. Ser. 301:9-22 [doi:10.3354/meps301009]. 
Paulsen, I. T., and others. 2003. Role of mobile DNA in the evolution of vancomycin-resistant Enterococcus faecalis. Science 299:2071-2074 [doi:10.1126/science.1080613].

Roll, B. M., and R. S. Fujioka. 1997. Sources of fecal indictor bacteria in a brackish, tropical stream and their impact on recreational water quality. Water Sci. Technol. 35:179-186 [doi:10.1016/S0273-1223(97)00255-2].

Shanks, O. C., C. A. Kelty, M. Sivaganesan, M. Varma, and R. A. Haugland. 2009. Quantitative PCR for genetic markers of human fecal pollution. Appl. Environ. Microbiol. 75:5507-5513 [doi:10.1128/AEM.00305-09].

Siefring, S., M. Varma, E. Atikovic, L. Wymer, and R. A. Haugland. 2008. Improved real-time PCR assays for the detection of fecal indicator bacteria in surface waters with different instrument and reagent systems. J. Water Health 6:225-237 [doi:10.2166/ wh.2008.022].

[USEPA] U.S. Environmental Protection Agency. 2000. Improved enumeration methods for the recreational water quality indicators: Enterococci and Escherichia coli. $<$ www.EPA.gov/OST/beaches $>$.

Whitman, R. L., and M. B. Nevers. 2003. Foreshore sand as a source of Escherichia coli in nearshore water of a Lake Michigan beach. Appl. Environ. Microbiol. 69:5555-5562 [doi:10.1128/AEM.69.9.5555-5562.2003].

Yamahara, K. M., B. A. Layton, A. E. Santoro, and A. B. Boehm. 2007. Beach sands along the California coast are diffuse sources of fecal bacteria to coastal waters. Environ. Sci. Technol. 41:4515-4521 [doi:10.1021/es062822n].

—, S. P. Walters, and A. B. Boehm. 2009. Growth of enterococci in unaltered, unseeded beach sands subjected to tidal wetting. Appl. Environ. Microbiol. 75:1517-1524 [doi:10.1128/AEM.02278-08].

Submitted 15 May 2009 Revised 16 December 2009 Accepted 20 January 2010 
Supplemental Table: Strategies currently used to correct qPCR-based estimates of environmental FIB

\section{A. Strategies accounting for DNA loss during the extraction protocol}

\begin{tabular}{|c|c|c|}
\hline Description & $\underline{\text { Pros }}$ & $\underline{\text { Cons }}$ \\
\hline $\begin{array}{l}\text { Use standard extraction protocol to } \\
\text { extract a known amount of } \\
\text { cultured target cells (e.g. } \\
\text { Yamahara et al. 2009) to determine } \\
\text { typical extraction efficiency. }\end{array}$ & $\begin{array}{l}\text {-Extracting the target cell controls } \\
\text { for losses that may be specific to the } \\
\text { cell type } \\
\text {-qPCR standard curve based on } \\
\text { purified genomic DNA can provide } \\
\text { second check on expected recovery } \\
\text { vs. actual recovery }\end{array}$ & $\begin{array}{l}\text {-Must able to accurately count } \\
\text { cells in culture } \\
\text {-Regularly spiking samples } \\
\text { with ENT cultures may } \\
\text { heighten the risk of workspace } \\
\text { contamination }\end{array}$ \\
\hline $\begin{array}{l}\text { Spike samples with known amount } \\
\text { of Lactococcus cells, extract and } \\
\text { quantify with modified TaqMan } \\
\text { probe to estimate extraction } \\
\text { recovery and inhibition (Siefring et } \\
\text { al. 2008) }\end{array}$ & $\begin{array}{l}\text {-Amplification region is the same, } \\
\text { and Lactococcus is closely related to } \\
\text { Enterococcus so extraction biases } \\
\text { probably similar } \\
\text {-Eliminates potential contamination } \\
\text { issues }\end{array}$ & $\begin{array}{l}\text {-Doesn't currently separate } \\
\text { losses due specifically to } \\
\text { extraction vs. inhibition, but } \\
\text { could be modified to do so }\end{array}$ \\
\hline $\begin{array}{l}\text { Spike subset of environmental } \\
\text { samples with known amount of } \\
\text { exogenous DNA standard (e.g. } \\
\text { pGEM method, Halliday et al. 2010) } \\
\text { prior to extraction }\end{array}$ & $\begin{array}{l}\text {-Amount of DNA is easily } \\
\text { measureable immediately prior to } \\
\text { spiking } \\
\text {-Avoids cross contamination issues }\end{array}$ & $\begin{array}{l}\text {-Spiking with naked DNA does } \\
\text { not represent cell lysis } \\
\text { efficiency and may be } \\
\text { recovered differently } \\
\text {-Different sequence being } \\
\text { amplified may ultimately } \\
\text { reflect different amplification } \\
\text { biases }\end{array}$ \\
\hline $\begin{array}{l}\text { Prepare a subset of "calibration } \\
\text { samples" with a known amount of } \\
\text { cultured target cells that are } \\
\text { extracted in tandem with } \\
\text { environmental samples. Spike lysis } \\
\text { buffer used for all samples with a } \\
\text { known amount of exogenous DNA } \\
\text { (e.g. salmon sperm, USEPA Draft } \\
\text { Method A). Ratio of target DNA in } \\
\text { environmental sample to calibration } \\
\text { sample is then multiplied by known } \\
\text { starting quantity of cells in } \\
\text { calibration sample. }\end{array}$ & $\begin{array}{l}\text { - Extracting the target cell captures } \\
\text { all losses that may be cell-specific } \\
\text {-All samples were prepared/analyzed } \\
\text { in tandem under the same } \\
\text { conditions, giving an estimate of } \\
\text { extraction efficiency for that day or } \\
\text { particular group of samples. Allows } \\
\text { additional quality control over time. }\end{array}$ & $\begin{array}{l}\text { - Must be able to accurately } \\
\text { count cells in culture } \\
\text { - Can't quantify loss in the } \\
\text { calibrator samples since they } \\
\text { are used for both the standard } \\
\text { curve and positive control (no } \\
\text { purified genomic DNA for } \\
\text { comparison) }\end{array}$ \\
\hline
\end{tabular}




\section{B. Strategies used to quantify inhibition of the qPCR reaction}

Spike environmental template DNA with known amount of purified target sequence (e.g. Yamahara et al. 2009)

Spike environmental template DNA with an artificially constructed target sequence, of the same size and with the same primer sites, but with a different TaqMan probe target (e.g. Shanks et al. 2004)

USEPA Draft Method A: A

reference sequence initially equal in all samples (salmon sperm DNA) is used to compare environmental samples with calibration samples $(\Delta \mathbf{\Delta C t})$

Spike DNA extracts with known amount of standard (pGEM) to quantify inhibition
-Target sequence reflects any amplification biases that would affect environmental samples -No need for multiple runs detecting different targets

-Differentiate spiked DNA from target DNA within the environmental sample -Good estimation of amplification biases specific to targets

-Combines target sequences with external control; ratios between can highlight loss due to extraction or inhibition in samples

-Versatility: inhibited sample types can be easily identified

\section{Cons}

- Regularly spiking samples with ENT genomic DNA may heighten the risk of workspace contamination

- Environmental target reporting could be dampened if falling within the range of spiked target DNA standard deviation.

-More difficult to modify across platforms (i.e., if interested in more than enterococci, must construct for each TaqMan assay of interest)

-Must do for all samples, increasing cost per sample -Currently not recommended to correct for losses in each sample, but used to identify severely inhibited samples - pGEM may be inhibited differently than target 


\section{CHAPTER 4: Enterococci in sands and water at estuarine beaches in southern Maine}

\section{Introduction}

Beaches in the northeastern U.S. have a relatively short bathing season (June through early September), but are prized as popular summer tourist destinations. In Maine, tourism is the state's largest industry and tourist spending related to beaches is estimated to bring in over $\$ 500$ million in annual earnings and support thousands of jobs $(9,13)$. As such, clean water is a valuable resource in the region and swimming advisories or beach closures, triggered by violations of bacterial water quality using methods and standards mandated by the U.S. Environmental Protection Agency (17), can have negative consequences on the local economy.

In southern Maine, local communities have begun to study the potential sources of bacteria to coastal waters by implementing sanitary surveys (10) and molecular source tracking (19) to identify sources of fecal indicator bacteria in watersheds and at popular recreational beaches. Many southern Maine beaches are associated with estuarine systems and tidal rivers that facilitate frequent exchanges between local watersheds and the beach. Thus, beaches can be impacted by bacteria from anthropogenic sources along the heavily developed Route 1 corridor as well as agricultural or wildlife sources via the tidal rivers. Source-tracking in the Webhannet and Merriland/Branch Brook/Little River watersheds documented mixed human, agricultural and wildlife E. coli ribotypes throughout the watershed as well as a significant portion of of ribotypes of unknown origin (19). Relative inputs from these sources may vary temporally, and rates of removal or retention of bacteria in the water column are likely influenced by the geography of the beach, tides, currents, etc. At an estuarine barrier beach in Ogunquit ME, riverine discharge was shown to account for a significant proportion of recreational beach water quality 
exceedances, and low salinity at the beach was a good indicator of the presence of the contaminated water mass (16). Tidal excursion in excess of $10 \mathrm{ft}$ was also a predictor of poor water quality at the beach, which was attributed to range in the salt marshes that increased the loading of bacteria in the water mass introduced to the beach (16).

However, increased tidal range also corresponds to an inundation of a greater area of beach sands, with the consequences to the sanitary conditions of sands and waters largely unexplored. Studies in California and Florida have documented the variation of coastal water quality with tides $(1,20)$ and linked increases in bacterial water quality to contact with bacteria-rich sands. The role of beach sands as a reservoir of fecal indicator bacteria has yet to be examined at marine beaches of the northeastern United States. In the case of estuarine-associated beaches in Maine, where great tidal ranges expose large swaths of sand and wave energy may readily resuspend bacteria into the water column, bacteria in sands may contribute to dry-weather water quality violations observed in the region. The popular bathing beaches in Wells, ME have a history of sporadic dry-weather bacterial water quality violations during the bathing season. They present an ideal case study for the region due to their location within the Wells National Estuarine Research Reserve (WNERR), which hosts automated physical and chemical data collection as part of NOAA’s estuarine System Wide Monitoring Program (SWMP).

The results presented here report how populations of the marine fecal indicator Enterococcus changed over time in water and sand, as measured by both membrane filtration (EPA Method 1600) and qPCR, and in relation to changing physical and meteorological conditions utilizing the data from the SWMP. Diagnostic multiple linear regression models were used to test whether the amount of bacteria in beach sands influences the variations observed in adjacent coastal water quality. Additionally, the presence of a bacterial agent of gastroenteritis (Campylobacter 
jejuni and Campylobacter coli) was surveyed to determine whether any association exists between this pathogen and abundance of enterococci in sands or waters

\section{Methods}

\subsection{Characterization of sites and sampling period}

The study was situated within the Webhannet river estuary in the town of Wells, ME, USA. The Webhannet river is fed by six streams, and the estuary runs parallel behind the heavily developed barrier beaches (Wells and Drakes Island). Behind the barrier beach the river forms Wells Harbor, which is dredged for boat traffic, before entering the Gulf of Maine through a pair of jetties (Figure 1). Wells Harbor Beach (WH) is on the inner side of the barrier island and adjacent to a beach parking lot - the warmer, calmer water is popular with families although the beach area is much smaller. Wells Beach (WB) and Drake's Island (DI) beach are on the ocean side of heavily developed barrier islands.

The SWMP's terrestrial weather station at WNERR measured air temperature, wind speed and direction, PAR and precipitation data at 15-minute intervals during the study period, and SWMP's water quality monitoring station (deployed within Wells harbor, see Figure 1) recorded water temperature, salinity, dissolved oxygen, water depth, chlorophyll, turbidity, and $\mathrm{pH}$ at $15-$ minute intervals. These data are presented in Figure 2, which shows that the first, second and third weeks of sampling all had wet weather events, while the final week did not. One major precipitation event was captured during the second week (July $\left.24^{\text {th }}, 2009\right)$ when $63 \mathrm{~mm}$ of rain fell in the ten hours preceding the 8am sampling, casuing 
Figure 1: Wells ME, the Route 1 corridor, and the Webhannet River. Three sampling sites are marked with yellow pushpins. With the exception of the protected marshes, the area is highly trafficked during the summer months.

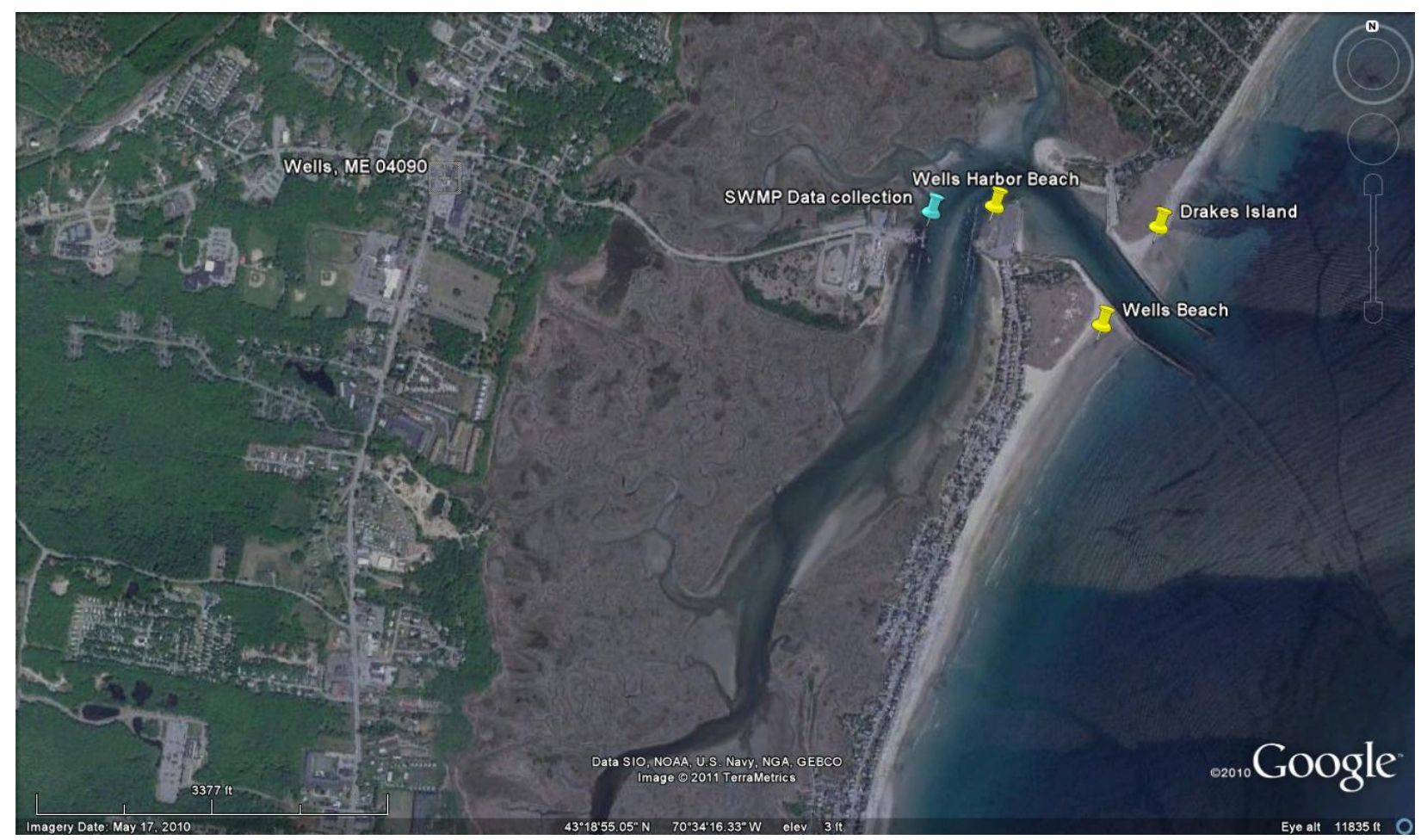

Figure 2: Environmental variables measured in situ at Wells Harbor and the WERR Weather Station during the course of the field study
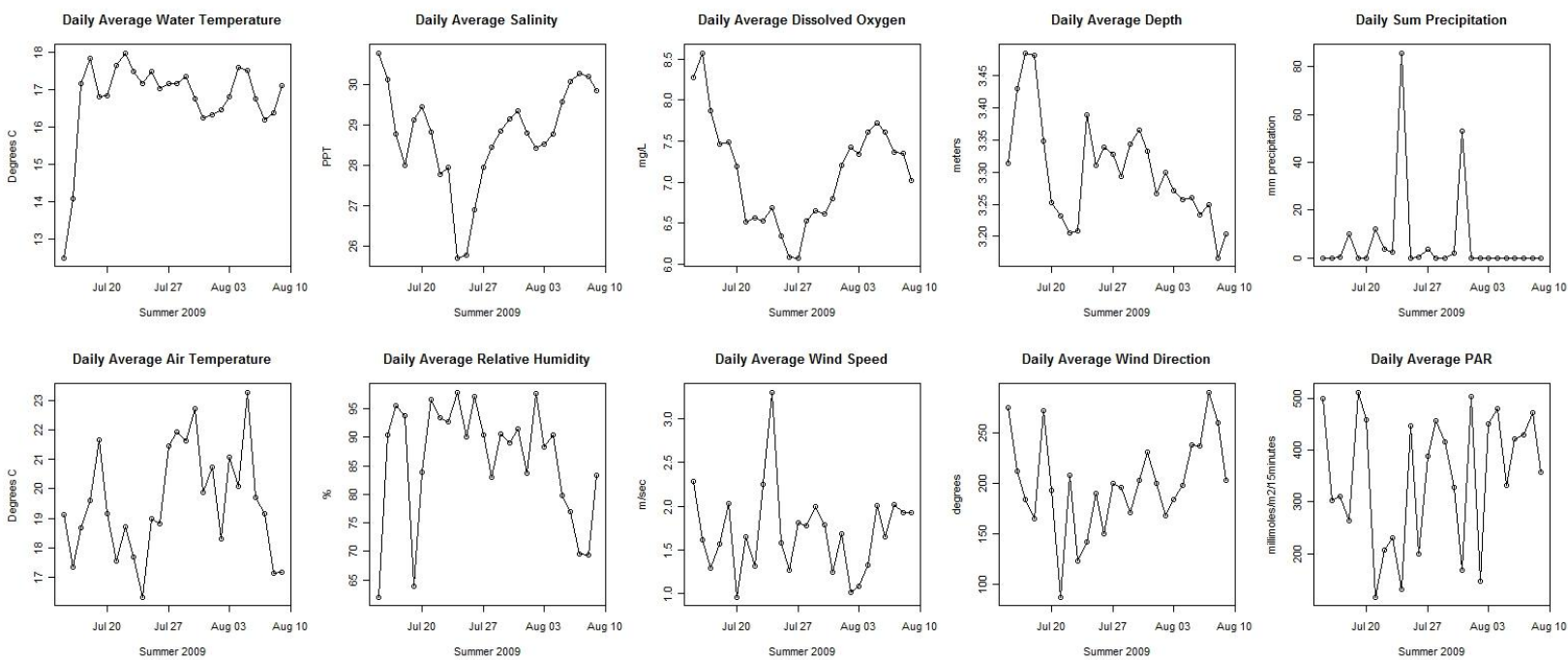


\subsection{Sample collection}

Sand and water samples were taken for bacterial analysis on 18 days between mid-July and midAugust during the summer of 2009. Samples were collected between 7am and 8am at each beach to mimic ordinary monitoring protocols. Water was collected in duplicate 1L nalgene bottles from calf-deep in the surf zone, surficial wet sand from the current water line was collected in duplicate 50mL Falcon tubes, and surficial dry sand from the high tide (wrack) line was collected in duplicate Falcon tubes. During each sampling event the air temperature, water temperature and salinity were all recorded in the field. All samples were stored on ice in a cooler and transported back to the lab for processing within six hours.

\subsection{Enumeration of enterococci from water}

Enterococci were assessed via membrane filtration as described in Method 1600 (17). Two liters of water collected at a site were combined and a 100mL aliquot was withdrawn for the membrane filtration and culture on mEI plates. A second $500 \mathrm{~mL}$ aliquot was filtered onto $47 \mathrm{~mm}$ GF/F (Whatman International Ltd.) that was folded and frozen in a $2 \mathrm{~mL}$ microcentrifuge tube for subsequent DNA extraction. A hot lysis buffer/bead beating method was utilized for nucleic acid extraction as described previously (4), and nucleic acids were precipitated with 0.6 volumes of isopropanol, recovered through centrifugation, air dried, and resuspended in 50uL sterile milli-Q water for use in the qPCR assay for Enterococcus spp.

Additionally, $15 \%$ of all the samples from each site had duplicate extractions, such that one of the duplicates had 2ng of pGEM plasmid amended to the filter to estimate loss of DNA through the extraction process. The second duplicate extraction was used for a pGEM assay amended 
with sample template DNA to examine inhibition among the samples and sites, as described previously (5).

\subsection{Enumeration of enterococci from sands}

A modified version of the US EPA Method 1600 was used with sand samples. Sands collected in duplicate tubes were combined and well mixed with a sterile spoon. From this homogenized sand sample, $25 \mathrm{~g}$ was weighed out, returned to a Falcon tube, amended with $30 \mathrm{~mL}$ of sterile phosphate buffered saline solution, and shaken vigorously by hand for two minutes. Particulate was allowed to settle for a minute before $10 \mathrm{~mL}$ of supernatant was withdrawn for membrane filtration and culture on mEI plates. Additionally, approximately $2 \mathrm{~g}$ of the homogenized sand sample were archived in $2 \mathrm{~mL}$ microcentrifuge tubes and frozen for subsequent DNA extraction using the MoBio PowerSoil DNA (MoBio, Carlsbad, CA) extraction kit for use in the qPCR assay for Enterococcus spp.

As with the water samples, $15 \%$ of all sand samples were extracted in duplicate, with one of the duplicates amended with pGEM before extraction to estimate DNA loss through the extraction protocol and one used in a pGEM assay designed to estimate inhibitors within the sample.

\section{5 qPCR Methods}

For the quantification of enterococci, each environmental sample was run in triplicate qPCR reactions, with each reaction containing $1 \mathrm{uL}$ of environmental DNA, 100ng each of the primers 748F and 854R (11), 12.5uL of the SYBR green master mix and 9.5uL sterile milli-Q water. A standard curve dilution series of 1 ng to $10 \mathrm{fg}$ Enterococcus faecalis purified genomic template DNA (ATTC \#700802) was run in duplicate on each plate, as were duplicate negative controls lacking any template DNA. Product melt curves from environmental samples were compared to 
product melt curves from template DNA as an additional quality control measure. Cell equivalents were then back-calculated per $100 \mathrm{~mL}$ water or $100 \mathrm{~g}$ sand, as described previously (5).

For the quantification of pGEM in samples that were spiked prior to the extraction protocol and in qPCR reactions where a known amount of pGEM was mixed with template DNA to test for inhibition, SYBR green detection was used with the primer set m13F and pGEMR. A standard curve dilution series of purified pGEM plasmid was run in duplicate on each plate.

\subsection{PCR for presencelabsence of Campylobacter jejuni and Campylobacter coli}

A semi-nested PCR assay (18) was used to amplify the intergenic sequence between the two Campylobacter flagellin genes, flaA and flaB. A subset of positive PCR products recovered from each site were sequenced to confirm identity.

\subsection{Statistics}

All bacterial data were $\log 10$-transformed to approach a normal distribution, but to meet all test assumptions nonparametric methods were used to test for significant differences in abundance of enterococci among sites and among sample types. Environmental variables collected through SWMP are archived every 15 minutes, so for each day of the study variables were extracted and averaged from the 24 -hour and 4-hour periods prior to the sampling events. This was done to give due consideration to the different time scales that may affect bacterial abundance in this environment - for example, including variation associated with the most recent tidal stage as well as to consider the diurnal inequality of tides in this region. Using the time series of these variable averages, as well as the temperature and salinity collected with each sample, the variables of possible significance to bacterial concentrations were identified based on the 
strength of any linear relationship between with the abundance of enterococci at each of the beaches and in each of the environmental sample types (water, wet sand and dry sand). The Pearson product-moment correlation coefficient (r) was calculated. The statistical program JMP (Version 7, SAS Institute Inc., Cary, NC) was used to construct site-specific multiple linear regression models using potentially explanatory environmental variables to predict the concentration of enterococcal CFU or qPCR-derived cell equivalents in the recreational waters at the three beaches in this study. Best-fit multiple linear regression models were constructed in a stepwise manner by adding variables to the model as they improved the adjusted $\mathrm{R}^{2}$, using an entry level cutoff of $\mathrm{p}=0.25$ for individual variables added to the model. The resulting leastsquares multiple linear regression was further analyzed by plotting the residuals vs. the predicted values to ensure the absence of any increasing or decreasing trends. To quantitatively detect multicollinearity, a correlation matrix was constructed for the independent variables in the model and the variance inflationary factors (VIF) were calculated. Unacceptable multicollinearity was defined as independent predictive variables having correlations $>0.7$ and/or any VIFs $>5$ in the model. All variables included in the final models had VIFs $<2.5$

\section{Results and Discussion}

\subsection{Distribution and abundance of culturable enterococci}

The geometric mean of ENT in water was $<10 \mathrm{CFU} / 100 \mathrm{~mL}$ at each site for the course of the sampling period. Two of the three water samples that exceeded the $104 \mathrm{CFU} / 100 \mathrm{~mL}$ limit were collected following large rain events and cooccured with other measurements of enterococci that were elevated but did not surpass the limit. One exceedance event and several elevated enterococci counts occurred during dry weather sampling periods. 
Sands were enriched in enterococci relative to ambient waters, with dry sands generally having 6-10 times more bacteria than the ambient water at that site, and with wet sands having 2-5 times more bacteria than the ambient water at the site. CFU counts were $\log 10(x+1)$ transformed for statistical analysis. The nonparametric Kruskall-Wallis test was used to compare rankabundance of enterococci cultured from water, wet sand and dry sand at each site. There were statistically significant differences between the $\mathrm{CFU}$ in water and sands at $\mathrm{WH}(\mathrm{p}=0.0005)$ and $\mathrm{WB}(\mathrm{p}=0.002)$ with dry sands having the highest mean rank abundance and water having the lowest mean rank abundance. At DI the difference was less signficant $(\mathrm{p}=0.054)$ due to similar rank abundances of CFU in water and wet sands (Figure 3A).

To test whether the abundance of culturable enterococci from a specific environmental sample type (e.g. water, wet sand, dry sand) significantly differed due to site, we again used the Kruskall-Wallis test to compare mean rank abundances of enterococci in each environmental matrix. There was no significant difference between the WH, WB and DI sites in terms of the distribution of culturable enterococci in water samples ( $\mathrm{p}=0.6891)$, wet sand samples $(\mathrm{p}=0.4169)$, or dry sand samples $(\mathrm{p}=0.4198)$. 
Figure 3: Distribution of Enterococcus in all water, wet sand, and dry sand samples during the study period A) Culturable enterococci B) qPCR enterococcus cell equivalents, C) qPCR enterococcus cell equivalents transformed to account for loss through the extraction process

A)
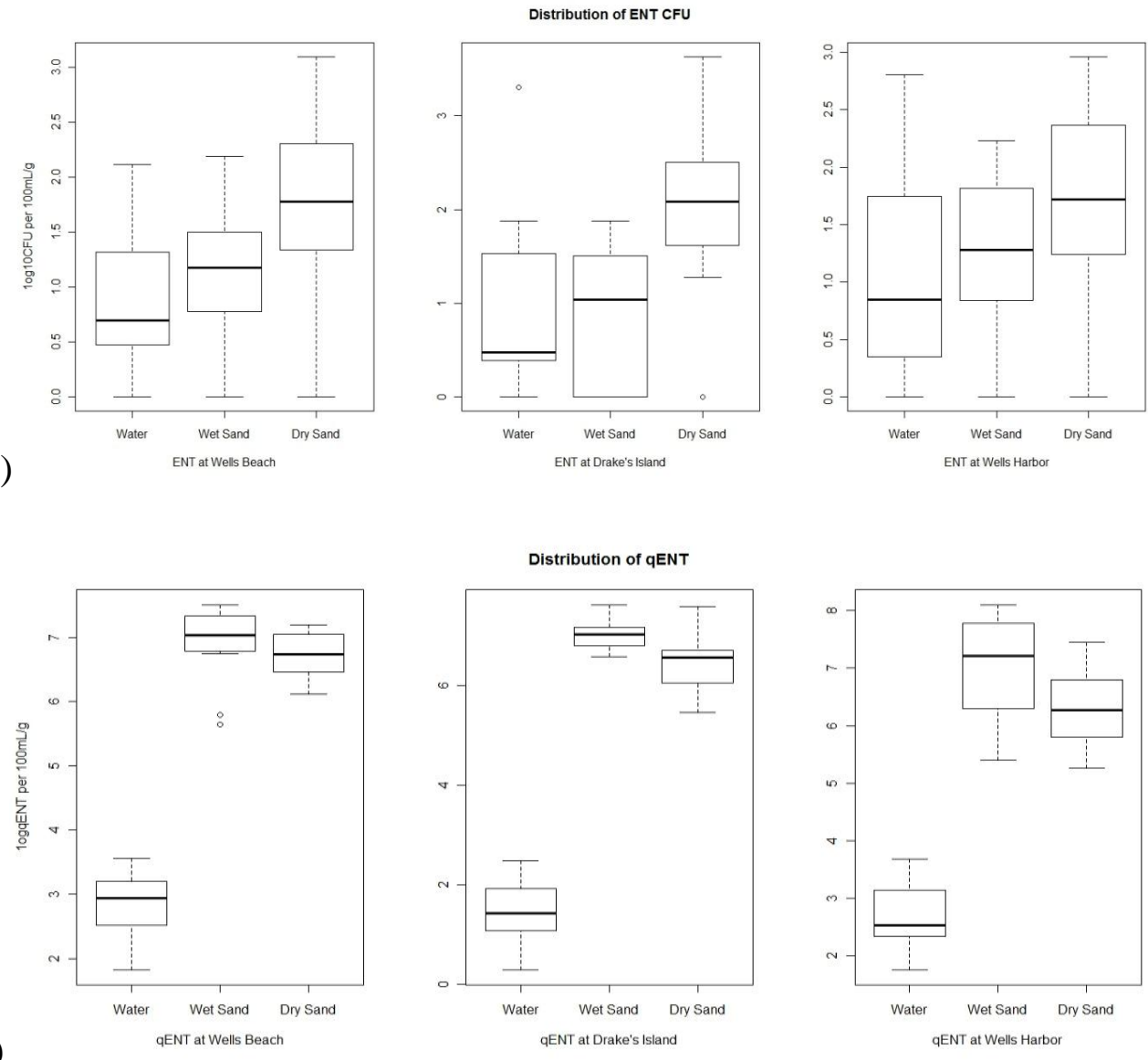

Distribution of qENT
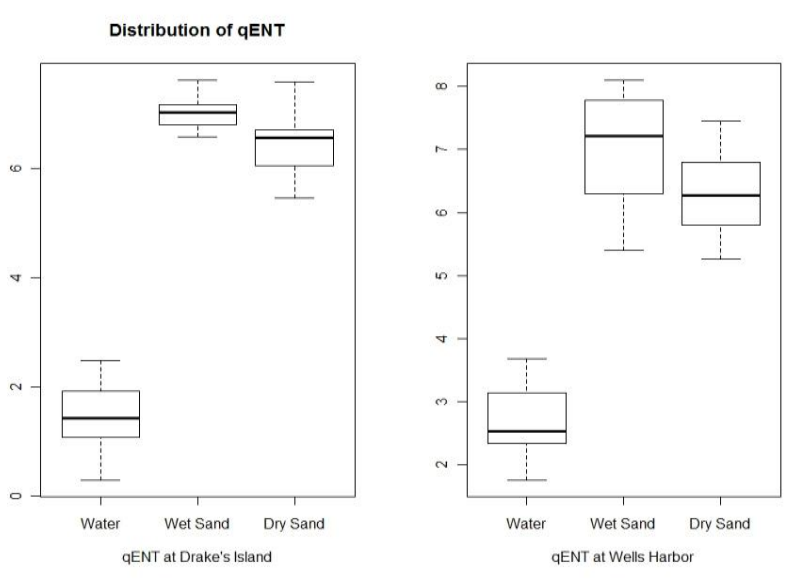

B)

Corrected distribution of qENT
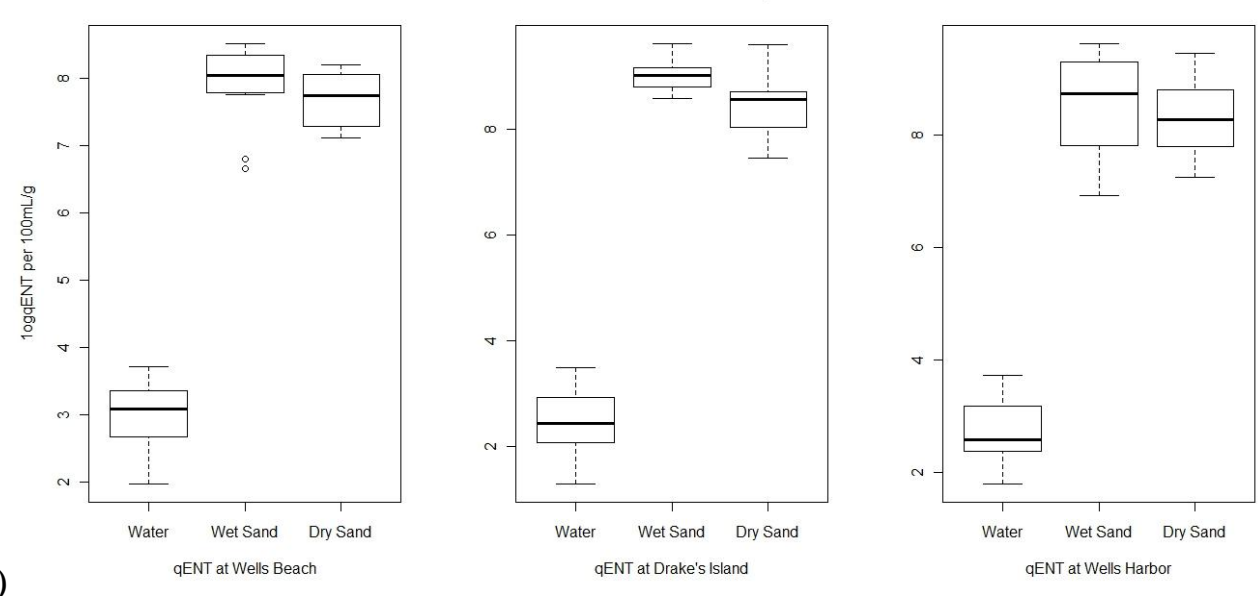


\subsection{Distribution and abundance of $q P C R$ enterococci cell equivalents}

Because molecular methods measure total DNA, the qPCR ENT cell equivalent (qENT) measurements include DNA from unculturable cells, dead cells, DNA from cells that would not be eluted from sand grains in our protocol for measuring CFU in sands, and any extracellular enterococcal DNA persisting in the environmental matrix. Thus, a relatively consistent background amount of target Enterococcus DNA persisted in all of the samples analyzed, with sands having the highest background level when normalized to cell equivalents per 100g (Figure 3B). All qENT are highly elevated in comparison to the CFU measurements for each environmental matrix at each site. The median ratio of CFU/qENT in water varied from site to site (from 0.14 to 0.58 ) but is comparable to ratios reported in the literature from freshwater (6) and marine (7) environments. The median ratio of CFU/qENT in sands reflects the apparently much higher background level of DNA in sand environments, and the ratios observed here (medians of $2.45^{*} 10^{-05}$ in dry sands and of $8.13 * 10^{-07}$ in wet sands) are similar to or slightly lower than ratios observed in sand-rewetting mesocosm experiments ((21), median ratio in sands $2 * 10^{-04}$, and ranging from $7 * 10^{-6}$ to $\left.3 * 10^{1}\right)$. CFU and qENT measurements did not increase and decrease in concert, which is examined in detail over the course of a storm event (Section 3.3).

qENT were also enriched in sands relative to waters but with wet sand harboring the highest amounts of DNA recovered (Figure 3B). Overall, each matrix was found to be highly significantly different (Kruskal-Wallis, $\mathrm{p}<0.0001$ ) at every site. Within environmental matrices, the sites were found to be highly significantly different in water samples, but less so in dry sand $(\mathrm{p}=0.1218)$ and not at all significantly different in wet sand $(\mathrm{p}=0.7974)$ where the signal is the most abundant, suggesting that wet sands are a consistent and fairly homogenized reservoir of enterococci DNA. 
Several factors may contribute to the high amounts of qPCR cell equivalents recovered from sands. Besides dead cells, qPCR may be reporting cells that have responded to environmental stressors by entering a nonculturable vegetative state (viable but non-culturable, or VBNC). VBNC cells can be detected by live/dead staining via treatment with propidium or ethidium compounds that intercalate with DNA within membrane-compromised (dead) cells. Enterococci have been reported to enter the $\operatorname{VBNC}$ state in seawater $(8,14)$. There is some concern that the intercalating compounds commonly used for live/dead differentiation overestimate viable cell counts in gram-positive cells (unpublished data). A more thorough analysis of the characteristics of VBNC enterococci combined with an examination of whether sands are environmental reservoirs of VBNC enterococci would help to contextualize the amount of enterococci cell equivalents detected through qPCR.

A second factor that may bias qPCR enterococci estimates is that in calculating cell equivalencies, we are assuming that all enterococci have the same number of copies of the $23 \mathrm{~S}$ RNA gene that contains the qPCR target sequence. In reality, E. faecalis has four copies of the gene per genome, E. faecium has six copies of the gene per genome, and although the qPCR assay targets all the enterococci, we do not know how many copies of the gene occur in the genomes of other species. The relative abundance of enterococcal species may therefore influence cell equivalencies. Likewise, we are assuming that cells have a single genome, which can be false during replication. The diversity of the 23S RNA genes amplified from environmental sand samples has not been quantified, and likely includes many enterococci and possibly other closely related lactic acid bacteria. The high recovery of enterococci DNA from sands suggests these potential biases should be examined in future work. 


\subsubsection{Average recovery of DNA through the extraction protocol and estimates of sample inhibition as determined through $p$ GEM experiments}

Despite the abundance of ENT DNA in our samples, the pGEM experimental results suggest that substantial amounts of DNA from environmental samples are lost through the extraction protocol. Sands had consistently low recovery of pGEM through the extraction protocol, with an average of $1.4 \%$ of pGEM spiked into sand sample extractions recovered subsequently via qPCR. Wet sand recovery deviated by site, with WH having higher recovery (3\%) than the barrier beaches (1\%). Compared to sands, the water samples had a higher recovery of pGEM through the extraction protocol, averaging 55\% but varied significantly by site; DI had the lowest average recovery on average at $8 \%, \mathrm{WB}$ had an average recovery of $70 \%$, and $\mathrm{WH}$ had an average recovery of $90 \%$. Figure $\mathbf{3 C}$ presents the distribution of qPCR data if transformed as previously described (5) to account for the average amount of DNA presumed lost through the extraction protocol and inhibition. Separate pGEM quantification of inhibition in these samples was minimal $(<10 \%)$ to undetectable, implying that a very clean product is the consequence of the low-yield sand extractions.

\subsection{Response in cENT and qENT prior to and following a major storm event}

The data from WH and WB illustrate the differences in the response of CFU and qENT to this precipitation-driven influx of non-point source pollution (Figure 4). 
Figure 4: Measurements of enterococci abundance at Wells Harbor and at Wells Beach, before and after a major precipitation event on 7/24/2009

A) ENT CFU abundance in water, wet sand and dry sand at WH (above) and WB (below)

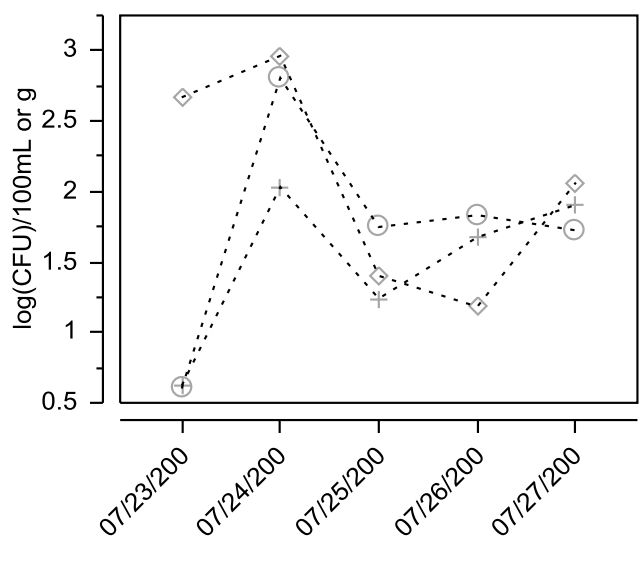

Dat

Y $\quad$-..WHcH $+\cdots$ WHcWS $\diamond-$. WHcDS

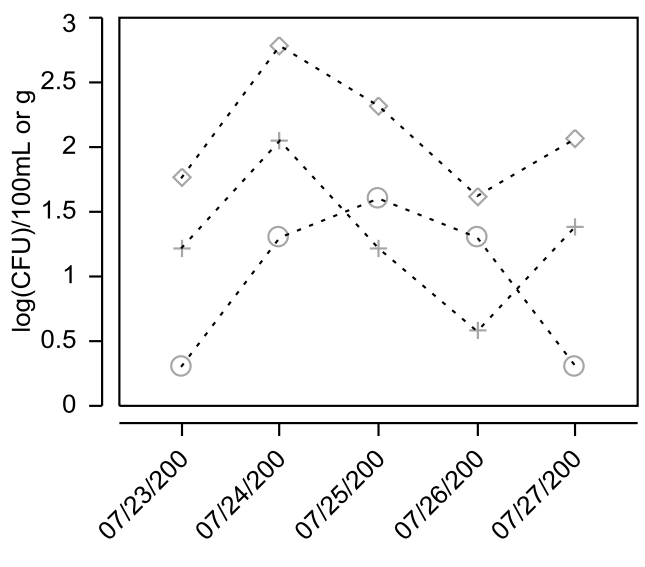

Dat

Y $\mathrm{O} \cdots \mathrm{WBcH}+\cdots$ WBcWS $\diamond \cdots$ WBcDS
B) ENT qPCR abundance in water, wet sand and dry sand at WH (above) and WB (below)

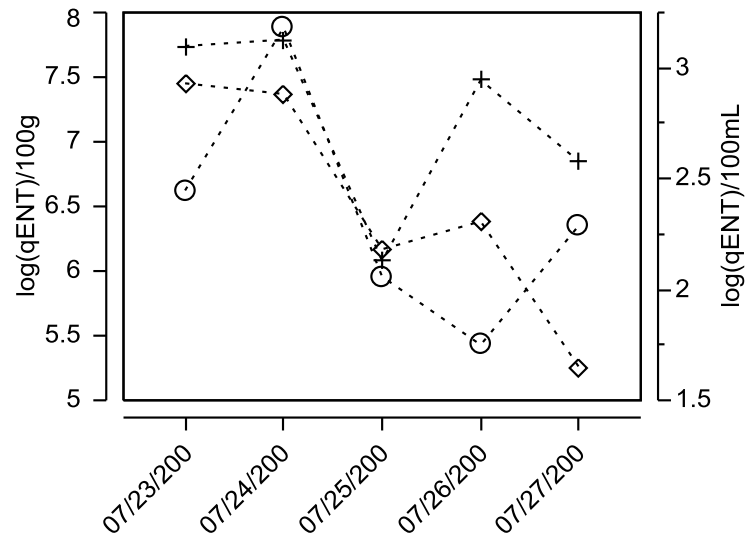

Dat

Left Scale: $\quad+\cdots$ WHqWS $\diamond-\cdots$ WHqDS

Right Scale: $\quad \mathrm{O} \cdot \mathrm{WH} \mathrm{WH}$

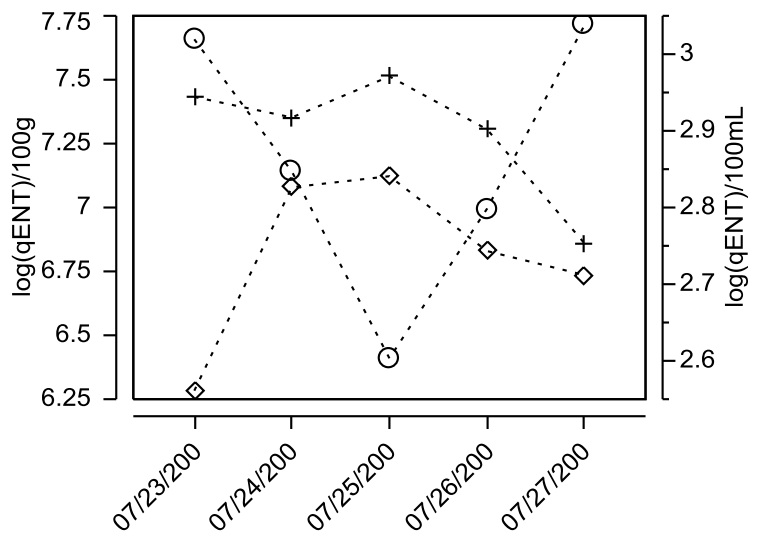

Dat

Left Scale: $\quad+\cdots$ WBqWS $\diamond-$. WBqDS

Right Scale: $\quad$ O - - WBqH 
For both methods of detection, the bacterial fluxes observed in the harbor are more dramatic than those observed at the barrier beach, where dilution occurs rapidly (note axis in Figure 4). In $\mathrm{WH}$, the observed peak in culturable enterococci occurred during the storm $(640 \mathrm{CFU} / 100 \mathrm{~mL})$, whereas Wells Beach only had 20CFU/100mL during the storm and the peak in enterococci CFU (40CFU/100mL) occurred the following day. In contrast to the Harbor, the barrier beaches were well below beach closure limits during and after of the storm event.

In the sands, $\mathrm{CFU}$ also peak during the storm event. By the end of the five day period, WB wet and dry sands had both returned to the pre-storm value. At Wells Harbor, there was a net increase in the wet sand CFU and a net decrease in the dry sand CFU. CFU and qENT cell equivalents behaved similarly in WH but differently at WB. qENT peaked in WH water during the storm event, but at WB there was no storm-associated peak in qENT. The qENT in the water during the five days at Wells Beach and during the last three days at Wells Harbor there is a general trend inverse of the trend observed in the sand.

\subsection{Relationship between environmental variables and enterococci abundance}

The correlations confirm that although qPCR and CFU results from the same samples are not strongly linearly related, there are relationships with environmental variables that transcend the method of bacterial quantification, relationships with variables that are specific to the method of quantification but common among sites, as well as relationships that are apparently specific to site but common among sample type (Table 1).

By both methods of bacterial quantification, the amount of ENT in the water at DI and WB were highly correlated to each other, and the amount of ENT in the wet sand at DI was highly correlated to the amount of ENT in the harbor water. ENT in WH waters was positively 
correlated to precipitation within $0-24 \mathrm{~h}$ of sampling, and negatively correlated to the amount of dry sand CFU at WH. Considering the recurring role of the variables water level and harbor depth at both DI and $\mathrm{WH}$, as well as their respective directions (negative or positive) and the significance of the relationships between sample types (Table 1), this data suggests that the freshwater masses discharged by the river are a primary source of bacteria impacting both sands and water at the harbor beach, and bacteria in the harbor may be transported to water and wet sand of the northward barrier beach, DI. Winds also were significantly correlated to both CFU and qENT measurements of bacterial abundance in water (windspeed at WH, and wind direction at Wells Beach), suggesting that wind-driven waves may resuspend bacteria from harbor sands into the water and that wind direction may influence whether bacteria are retained at the barrier beaches.

Rainfall was consistently significantly related to bacterial abundance, and qENT and culturable ENT in water samples were often paired in negative or positive correlations with the precipitation variables (e.g., ENT abundance in WH water was positively correlated with precipitation within $0-24 \mathrm{~h}$ and negatively correlated to precipitation within $24-48 \mathrm{~h}$, suggesting bacteria were flushed within two days). qENT abundance in water samples at barrier beaches lagged behind the harbor, with water samples at both barrier beaches (DI and WB) positively associated with the amount of rainfall within the previous 24-48hours ( $r=0.59$ and 0.47 , respectively).

\subsection{Site-specific Multiple Linear Regression Models}

At least two models were identified for describing the water quality at each site, one with CFU as the response variable and one with qENT as the response variable. Beyond that, models were 
constructed as described in the statistical methods section, by selecting from sets of variables that excluded (abiotic) or included (biotic) the sand bacterial abundance at the site as potential explanatory variables for water. The purpose of dual model selection was to test whether the addition of beach sand data collected and measured with the same method would improved the power of the model in explaining the variation observed in water quality. The best models with their independent predictor variables are listed in Table 2.

\begin{tabular}{|c|c|c|c|}
\hline \multicolumn{4}{|c|}{ Table 1: Correlations between monitoring method, sample type and survey sites } \\
\hline Variable & $\begin{array}{l}\text { Site/Sample } \\
\text { Type }\end{array}$ & $\begin{array}{l}\text { CFU correlation } \\
\text { coefficient }(p)\end{array}$ & $\begin{array}{l}q \text { ENT correlation } \\
\text { coefficient }(p)\end{array}$ \\
\hline Harbor depth & DI water & $-0.429(0.164)$ & $-0.8402(0.0012)$ \\
\hline WH dry sand CFU & WH water & $-0.4345(0.0813)$ & $-0.5433(0.03)$ \\
\hline Precipitation $0-24 \mathrm{~h}$ & $\begin{array}{l}\text { WH water } \\
\text { DI wet sands }\end{array}$ & $\begin{array}{l}0.5823(0.0142) \\
0.5028(0.975) \\
\end{array}$ & $\begin{array}{l}0.3331(0.2074) \\
0.5101(0.0902)\end{array}$ \\
\hline Precipitation $24-48 \mathrm{~h}$ & WH wet sand & $0.3048(0.2343)$ & $0.3592(0.1718)$ \\
\hline Air temperature & DI wet sands & $-0.6929(0.0125)$ & $-0.7144(0.009)$ \\
\hline PAR & WB wet sands & $-0.3714(0.1422)$ & $-0.331(0.1994)$ \\
\hline $\begin{array}{l}\text { Water level } \\
\text { (at time of sample) }\end{array}$ & WH dry sand & $0.4311(0.084)$ & $0.3333(0.2247)$ \\
\hline Relative humidity & WB dry sands & $0.4386(0.0892)$ & $0.4386(0.0892)$ \\
\hline \multicolumn{4}{|c|}{$\begin{array}{l}\text { B. Correlative relationships consistent among particular sample type but exclusive to } \\
\text { CFU or qENT detection }\end{array}$} \\
\hline Variable & $\begin{array}{l}\text { Method/Sample } \\
\text { type }\end{array}$ & Site & $\begin{array}{l}\text { Correlation coefficient } \\
(p)\end{array}$ \\
\hline Harbor depth & qENT water & $\begin{array}{l}\text { WH } \\
\text { WB } \\
\text { DI }\end{array}$ & $\begin{array}{l}-0.7129(0.0019) \\
-0.6562(0.0042) \\
-0.8402(0.0012)\end{array}$ \\
\hline \multicolumn{4}{|c|}{$\begin{array}{l}\text { C. Variables in correlative relationships consistent among all sample types at a single } \\
\text { site }\end{array}$} \\
\hline Variable & $\begin{array}{l}\text { Site and } \\
\text { method }\end{array}$ & Sample type & $\begin{array}{l}\text { Correlation coefficient } \\
(p)\end{array}$ \\
\hline Harbor depth & DI qENT & $\begin{array}{l}\text { Water } \\
\text { Wet sand } \\
\text { Dry sand } \\
\end{array}$ & $\begin{array}{l}-0.8402(0.0012) \\
-0.4052(0.1913) \\
-0.4249(0.1686)\end{array}$ \\
\hline $\begin{array}{l}\text { Water level (at time } \\
\text { of sample) }\end{array}$ & WH CFU & $\begin{array}{l}\text { Water } \\
\text { Wet sand } \\
\text { Dry sand }\end{array}$ & $\begin{array}{l}-0.5438(0.024) \\
-0.6667(0.0035) \\
0.4211(0.084)\end{array}$ \\
\hline
\end{tabular}




\begin{tabular}{|c|c|c|}
\hline $\begin{array}{l}\text { Model and variable } \\
\text { selection }\end{array}$ & $\begin{array}{l}\text { Final R2 of Least } \\
\text { Squares Regression } \\
\text { following stepwise } \\
\text { variable selection: }\end{array}$ & Variables in final model: \\
\hline $\begin{array}{l}\text { Wells Harbor CFU } \\
\text { (abiotic) }\end{array}$ & $\begin{array}{l}\mathrm{R} 2=0.70, \text { adj } \mathrm{R} 2=0.62, \\
\mathrm{p}=0.0019, \\
\mathrm{RMSE}=0.4991\end{array}$ & $\begin{array}{l}\text { Water level at time of sampling } \\
\text { Minimum salinity during previous } 24 \mathrm{~h} \\
\text { Precip., } 0-24 \mathrm{~h}\end{array}$ \\
\hline $\begin{array}{l}\text { Wells Harbor CFU } \\
\text { (including beach sands) }\end{array}$ & $\begin{array}{l}\mathrm{R} 2=0.75, \text { adj } \mathrm{R} 2=0.68 \\
\mathrm{p}=0.0007 \\
\mathrm{RMSE}=0.4583\end{array}$ & $\begin{array}{l}\text { Log(wet sand CFU) } \\
\text { Log(dry sand CFU) } \\
\text { Precip., 0-24h }\end{array}$ \\
\hline $\begin{array}{l}\text { Wells Harbor qENT } \\
\text { (abiotic) }\end{array}$ & $\begin{array}{l}\mathrm{R} 2=0.86, \text { adj } \mathrm{R} 2=0.81 \\
\mathrm{p}=0.0001, \mathrm{RMSE}=0.25\end{array}$ & $\begin{array}{l}\text { Depth } \\
\text { Salinity (previous } 4 \mathrm{~h} \text { avg) } \\
\text { Precip., 0-24h } \\
\text { Relative humidity }\end{array}$ \\
\hline $\begin{array}{l}\text { Wells Harbor qENT } \\
\text { (including beach sands) }\end{array}$ & $\begin{array}{l}\mathrm{R} 2=0.94, \text { adj } \mathrm{R} 2=0.90 \\
\mathrm{p}<0.0001 \\
\mathrm{RMSE}=0.1876\end{array}$ & $\begin{array}{l}\text { Depth } \\
\text { Salinity (previous } 4 \mathrm{~h} \text { avg) } \\
\text { Precip., 0-24h } \\
\text { Log(dry sand qENT) } \\
\text { Relative humidity }\end{array}$ \\
\hline $\begin{array}{l}\text { Wells Beach CFU } \\
\text { (abiotic - no model } \\
\text { incorporating beach } \\
\text { sands was significant) }\end{array}$ & $\begin{array}{l}\mathrm{R} 2=0.4, \operatorname{adj} \mathrm{R} 2=0.30 \\
\mathrm{p}=0.02, \mathrm{RMSE}=0.4512\end{array}$ & $\begin{array}{l}\text { PAR } \\
\text { Temperature of water sample }\end{array}$ \\
\hline $\begin{array}{l}\text { Wells Beach qENT } \\
\text { (abiotic) }\end{array}$ & $\begin{array}{l}\mathrm{R} 2=0.79, \text { adj } \mathrm{R} 2=0.74 \\
\mathrm{p}<0.0001, \mathrm{RMSE}=0.26\end{array}$ & $\begin{array}{l}\text { Depth } \\
\text { Minimum salinity during previous } 24 \mathrm{~h} \\
\text { Air temperature }\end{array}$ \\
\hline $\begin{array}{l}\text { Wells Beach qENT } \\
\text { (including beach sands) }\end{array}$ & $\begin{array}{l}\mathrm{R} 2=0.90, \text { adj } \mathrm{R} 2=0.70 \\
\mathrm{p}<0.0001, \\
\mathrm{RMSE}=0.1971\end{array}$ & $\begin{array}{l}\text { Depth } \\
\text { Minimum salinity during previous } 24 \mathrm{~h} \\
\text { Log(wet sand qENT) } \\
\text { Precip., 0-24h } \\
\text { Avg windspeed }\end{array}$ \\
\hline $\begin{array}{l}\text { Drake's Island CFU } \\
\text { (abiotic) }\end{array}$ & $\begin{array}{l}\mathrm{R} 2=0.81, \operatorname{adj} \mathrm{R} 2=0.70 \\
\mathrm{p}=0.01, \mathrm{RMSE}=0.495\end{array}$ & $\begin{array}{l}\text { Water level at time of sample } \\
\text { Avg wind direction } \\
\text { Air temperature } \\
\text { Relative humidity }\end{array}$ \\
\hline $\begin{array}{l}\text { Drake's Island CFU } \\
\text { (including beach sands) }\end{array}$ & & $\begin{array}{l}\text { WS CFU would improve the model but } \\
\text { is strongly correlated to air } \\
\text { temperature ( } r=-0.6929) \text { and thus can't } \\
\text { be included }\end{array}$ \\
\hline $\begin{array}{l}\text { Drake's Island qENT } \\
\text { (abiotic) }\end{array}$ & $\begin{array}{l}\mathrm{R} 2=0.89, \text { adj } \mathrm{R} 2=0.85, \\
\mathrm{p}=0.0008, \\
\mathrm{RMSE}=0.2472\end{array}$ & $\begin{array}{l}\text { YSI depth } \\
\text { Air temperature } \\
\text { Water Temperature }\end{array}$ \\
\hline $\begin{array}{l}\text { Drake's Island qENT } \\
\text { (including beach sands) }\end{array}$ & & $\begin{array}{l}\text { WS qENT would improve the model } \\
\text { but collinear with air temperature }(r= \\
-0.7144)\end{array}$ \\
\hline
\end{tabular}




\subsubsection{Models of water quality at Wells Harbor}

CFU water quality could be predicted by a combination of environmental variables at Wells Harbor, with the model using purely abiotic data selecting water level at time of sampling, YSI minimum salinity in previous $24 \mathrm{~h}$, and total precipitation with 0-24h as explanatory variables. This model had an $\mathrm{R}^{2}$ of 0.70 (Adj. $\mathrm{R}^{2}=0.62$ ). Adding sands to the potential explanatory variables changed the variable selection to first add wet sand $\mathrm{CFU}$, dry sand CFU, and continued to include total precipitation with $0-24 \mathrm{~h}$; this slightly increased the $\mathrm{R}^{2}$ to 0.74 , and the adjusted $\mathrm{R}^{2}$ to 0.68 . In the first model, water level relates the water level to the wet and dry sand. In the second model, the amount of bacteria in wet sands on the day of sampling explained approximately $27 \%$ of the variability observed in water quality and the amount of bacteria in dry sands explained approximately $13 \%$ of the variability observed in CFU water quality.

Environmental variables also successfully described a majority of the variation observed in qENT water quality at Wells Harbor, and again adding sand bacterial data to the model selection process improved the best-fit models with an approximately 0.10 increase in adjusted and actual $\mathrm{R}^{2}$ values. The $\mathrm{qENT}$ model built without sand $\left(\mathrm{R}^{2}=0.84\right)$ utilized the YSI measurements of depth, average salinity within the four hours prior to sampling, precipitation within $0-24 \mathrm{~h}$, and relative humidity. The qENT model built with sands as potential explanatory variables simply added the WHqDS as the fourth parameter, which contributed to approximately $4 \%$ of the variability observed in qENT water quality.

Thus, for the Wells Harbor beach, the inclusion of beach sand data improved models describing the variability of the Wells Harbor water quality; in both CFU and qENT data sets, dry sands were included in the model. The qPCR model relied exclusively on in-situ measurements. The 
consistent inclusion of variables such as precipitation, salinity, and water level at the time of the sample or the average depth in the harbor in all models implicate the tidal exchange with the watershed and runoff into the river as a major contributor to the variations in water quality at the swimming beach.

\subsubsection{Models of water quality at Wells Beach}

Wells Beach CFU were not as well explained by environmental parameters, with the water temperature of the sample and daily average PAR being the only variables linearly combined in a relatively poor model $\left(\mathrm{R}^{2}=0.40\right)$. Numerous other lab and field studies have documented the effects of water temperature (12)and sunlight $(2,3,15)$ on the survival or die-off of culturable fecal indicator bacteria in environmental waters.

Environmental variables were far more successful in describing the variability of qENT at Wells Beach. Using abiotic parameters (minimum salinity, depth, and air temperature) a model was constructed with an $\mathrm{R}^{2}$ of 0.79 . Incorporating the qENT of wet beach sand and average windspeed in lieu of air temperature, and adding precipitation within $0-24 \mathrm{~h}$, the best-fit model produced an $\mathrm{R}^{2}$ of 0.90 , with wet sands responsible for approximately $20 \%$ of the variation observed in qENT water quality. qENT in Wells Beach waters increases with wind speed and were also inversely related to the amount of qENT in wet sands, suggesting that wind-driven suspension as well as cells or DNA resettling into wet sands may affect the water quality dynamics here.

\subsubsection{Models of water quality at Drakes Island}

CFU water quality data at Drakes Island were better explained by environmental parameters through multiple linear regression than they were at Wells Beach. The best-fit model for CFU 
utilized water level at the time of sampling, daily average wind direction, air temperature, and relative humidity for an $\mathrm{R}^{2}$ of 0.81 and adjusted $\mathrm{R}^{2}$ of 0.70 ; adding sand variables to the stepwise selection resulted in selection of the same first four variables, and then the addition of wet sand CFU; however, at this site wet sand was strongly significantly correlated to air temperature and thus could not be added to the model due to the effects of collinearity.

The models constructed to fit qENT data were equally strong, utilizing the YSI depth, air temperature and water temperature for $\mathrm{R}^{2}$ of 0.89 and adj. $\mathrm{R}^{2}$ of 0.85 . Adding sands to the selection resulted in the same outcome as was observed with the CFU data; the initial three variables were selected and then wet sand qENT was added, but wet sand qENT also was correlated to air temperature and thus could not be included in the model.

In both models, variables like air temperature and relative humidity correspond to abundance of bacteria in sand and are relevant to water quality.

\subsection{Recovery of Campylobacter from Sands and Water}

Eleven samples (2.5\% of all samples tested) had positive nested-PCR products indicating the presence of Campylobacter pathogenic species jejuni and coli. Sequencing confirmed PCR products were $C$. jejuni. The majority of the positive samples (6/11) were recovered from dry sands, followed by water (3/11) and wet sand (2/11). Campylobacter was recovered from waters following the major precipitation events but recovered from sands both prior to and following precipitation events. Campylobacter was recovered from at least one environmental sample from each site, but the frequency of Campylobacter recovery from each specific site and sample type was positively and significantly correlated to the ENT CFU geometric mean for that site during the sampling period ( $\mathrm{rho}=0.718, \mathrm{p}=0.0292)$. In short, the dry sand at all of the sites as 
well as the wet sands at WH, which had geometric means ranging from 50CFU/100g to 150CFU/100g during the sampling period, all had a higher frequency of Campylobacter-positive samples than the wet sands from DI and WB or any of the waters, all of which had geometric means $<12$ ENT CFU/100 $\mathrm{g}$ or $\mathrm{mL}$ during the same time period. This suggests that the sands that are enriched in culturable enterococci may also be more likely to contain pathogens.

\section{Conclusions}

4.1 Beach sands in the northeast have ENT loads that exceed those in adjacent waters, and likely act as a repository for bacteria flushed out of tidal marsh systems

The results presented here show that the temperate coastal beaches in southern Maine host viable enterococci at densities that are greater than those found in water, and are a reservoir of enterococci DNA that is several orders of magnitude higher than that found in water. The sand reservoirs of viable enterococci cells and DNA both appear to influence water quality measurements. Even when sand bacterial abundance was not explicitly included in the models of water quality, the ubiquity of the explanatory variables water level at the time of sampling and depth within the harbor, both indicative of tidal stage, indicate that water and beach sand interactions influence water quality. Some environmental variables that are related to water quality may in fact be a proxy for sand bacterial levels; further exploration of these relationships may negate the need to measure sand bacterial concentrations at sites of interest. However, tidal and sand variables were less influential on water quality than stormwater.

As the summer climate in Maine is relatively cool, many beachgoers in this region spend the majority of their beach-going hours recreating on the large swaths of sand exposed by the major tidal cycles. C. jejuni, the most common bacterial agent of gastrointestinal distress, was 
recovered more frequently from beach sand samples than from water samples, and samples positive for the presence of this pathogen typically hosted higher amounts of ENT. Although the presence of Campylobacter was detected in a minority of samples, this does suggest the abundance of fecal indicators in beach sands may be indicative of other disease-causing organisms and deserves further study.

Dogs, cats, birds and wild animals can be sources of pathogenic Campylobacter. Approximately $17 \%$ of the land within the Webhannet watershed is conserved wetland, but overall the area is highly trafficked via US Route 1 and I-95. It is especially impacted by humans in the summer months with a burgeoning tourist population. Previous source-tracking of fecal pollution in this watershed used ribotypes of the freshwater fecal indicator E. coli that were isolated from potential source material and environmental samples ( $n=159$ unique ribotypes) within the Webhannet river estuary, and the authors ultimately found a mix of human (18\%), livestock $(10.5 \%)$, wildlife(32\%) and pet $(9.5 \%)$ ribotypes in environmental samples (19). Thus, it is likely that fecal indicator bacteria observed in Wells Harbor in this study result from the contributions of a diversity of sources. Furthermore, in the source-tracking study many ribotypes $(30 \%)$ didn't match any source material recovered from environmental samples (19); having documented robust populations of ENT in sands in this study, it raises the a possibility that the unidentified ribotypes found in the previous study may represent $E$. coli communities naturalized in sands or sediments within the estuary.

\subsection{Culture-based and qPCR monitoring differ in their daily results, but data from both methods} corresponded to environmental parameters that are relatively easy to measure 
Overall, the results described here are similar to ratios of CFU:qENT reported in the literature from other marine and freshwater environments $(6,7,21)$. The pGEM experiments demonstrated that sites can have different extraction efficiencies, and although correcting for these differences did not significantly change the relationships between bacterial populations at the sites in this study, this information helps to identify where losses of DNA occur in our sample processing and detection methodos. Although CFU and qPCR were not significantly linearly related, the use of similar predictive variables in the multiple linear regression models for each site (e.g. Table 2) suggests that the abundance of viable cells and total DNA are still driven by similar factors.

The diagnostic multiple linear regression models overwhelmingly utilized variables collected through the high frequency, in situ data loggers rather than the single environmental data points taken at the time of the sample. Even at the barrier beach sites which are spatially and environmentally distinct from the site of the water data logger, many of the in situ variables were strongly related to water quality. Since these statistical models incorporate only about $1 / 3$ of the bathing season and were based on data collected during an abnormally rainy summer, it is unlikely that they would have strong predictive power over time; nevertheless, the results suggest that predictive modeling could be developed using monitoring infrastructure already in place. This would help managers anticipate the effects of storms and high tides on water quality, and especially to distinguish between weather-related variation and a external pollution events, regardless of whether a culture-based or molecular method is employed for monitoring. 


\section{Acknowledgements}

This work was funded by an Ocean Venture Fund award to E.H. from the Woods Hole

Oceanographic Institution. The authors thank Dr. Michele Dionne and Jeremy Miller for their generous support at the Wells National Estuarine Research Reserve, as well as Cayce Dalton and Meri Ratzel for field work assistance.

\section{References}

1. Boehm, A. B., and S. B. Weisberg. 2005. Tidal forcing of enterococci at marine recreational beaches at fortnightly and semidiurnal frequencies. Environmental science \& technology 39:5575-5583.

2. Boehm, A. B., K. M. Yamahara, D. C. Love, B. M. Peterson, K. McNeill, and K. L. Nelson. 2009. Covariation and photoinactivation of traditional and novel indicator organisms and human viruses at a sewage-impacted marine beach. Environmental science \& technology 43:8046-8052.

3. Fujioka, R. S., H. H. Hashimoto, E. B. Siwak, and R. Young. 1981. Effect of sunlight on survival of indicator bacteria in seawater. Appl Environ Microbiol 41:690.

4. Gast, R. J., M. R. Dennett, and D. A. Caron. 2004. Characterization of protistan assemblages in the Ross Sea, Antarctica, by denaturing gradient gel electrophoresis. Appl Environ Microbiol 70:2028.

5. Halliday, E., J. F. Griffith, and R. J. Gast. 2010. Use of an exogenous plasmid standard and quantitative PCR to monitor spatial and temporal distribution of Enterococcus spp. in beach sands. Limnol. Oceanogr. Methods 8:146-154.

6. Haugland, R. A., S. C. Siefring, L. J. Wymer, K. P. Brenner, and A. P. Dufour. 2005. Comparison of Enterococcus measurements in freshwater at two recreational beaches by quantitative polymerase chain reaction and membrane filter culture analysis. Water Res 39:559-568.

7. He, J. W., and S. Jiang. 2005. Quantification of enterococci and human adenoviruses in environmental samples by real-time PCR. Appl Environ Microbiol 71:2250.

8. Heim, S., M. D. M. Lleo, B. Bonato, C. A. Guzman, and P. Canepari. 2002. The viable but nonculturable state and starvation are different stress responses of Enterococcus faecalis, as determined by proteome analysis. Journal of bacteriology 184:6739-6745.

9. Levert, M., and D. Douglass. 2009. Presented at the Maine Beaches Conference, South Portland, ME.

10. Lindberg, K. 2010. Municipal Guide to Clean Water: Conducting Sanitary Surveys to Improve Coastal Water Quality. Maine Healthy Beaches Program, www.mainehealthybeaches.org.

11. Ludwig, W., and K. H. Schleifer. 2000. How quantitative is quantitative PCR with respect to cell counts? Systematic and applied microbiology 23:556.

12. McFeters, G. A., and D. G. Stuart. 1972. Survival of coliform bacteria in natural waters: field and laboratory studies with membrane-filter chambers. Appl Environ Microbiol 24:805. 
13. Office, M. S. P. 2008. Tourism Powers Maine Economy: A Reference Guide to Tourism and the Maine Economy.

14. Signoretto, C., M. del Mar Lleò, M. C. Tafi, and P. Canepari. 2000. Cell Wall Chemical Composition ofEnterococcus faecalis in the Viable but Nonculturable State. Appl Environ Microbiol 66:1953-1959.

15. Sinton, L. W., C. H. Hall, P. A. Lynch, and R. J. Davies-Colley. 2002. Sunlight inactivation of fecal indicator bacteria and bacteriophages from waste stabilization pond effluent in fresh and saline waters. Appl Environ Microbiol 68:1122.

16. Slovinsky, P. A., and S. M. Dickson. 2008. Microbial Pollution Levels and Transport Pathways at Ogunquit Beach. Maine Geological Survey.

17. U.S.E.P.A. 2002. Method 1600: membrane filter test method for enterococci in water.

18. Waage, A. S., T. Vardund, V. Lund, and G. Kapperud. 1999. Detection of small numbers of Campylobacter jejuni and Campylobacter coli cells in environmental water, sewage, and food samples by a seminested PCR assay. Appl Environ Microbiol 65:1636.

19. Whiting-Grant, K., F. Dillon, C. Dalton, M. Dionne, and S. Jones. 2003. Webhanet River Watershed Report.

20. Wright, M., A. Abdelzaher, H. Solo-Gabriele, S. Elmir, and L. Fleming. 2011. The inter-tidal zone is the pathway of input of enterococci to a subtropical recreational marine beach. Water science and technology 63:542-549.

21. Yamahara, K. M., S. P. Walters, and A. B. Boehm. 2009. Growth of enterococci in unaltered, unseeded beach sands subjected to tidal wetting. Appl Environ Microbiol 75:1517. 


\section{CHAPTER 5: Dry-weather distribution of enterococci in sands and water at Provincetown Harbor, MA}

\section{Introduction}

The indicator bacteria Enterococcus (ENT) is used as a proxy for fecal contamination in marine recreational waters, and is routinely monitored at beaches to prevent bather contact with contaminated waters in compliance with U.S. federal guidelines (37). However, contrary to the assumption that ENT isolated from the environment must be associated with the presence of fecal matter, observations from many beaches have documented that ENT can persist in the environment and often can be found at high densities in beach sands (13).

Understanding how the abundance of ENT in sands may be impacted by natural variation in environmental conditions, and whether ENT in sand co-varies with ENT in water, is important for two reasons: first, to provide baseline data on ENT abundance in environmental sands to contextualize the potential human health risk as people sit on, dig in, or otherwise interact with sands; and second, to discover whether sands can be a source of ENT to bathing waters and what conditions in the environment promote or reduce the exchange of bacteria between sand and water. The impact of environmental conditions on the survival of ENT in seawater have been experimentally observed $(11,24,34)$ as well as modeled from the results of observations in the field (4); collectively, results indicate temperature, salinity and UV influence ENT inactivation in seawater. Additional studies suggest ENT are able to persist longer if they are particleassociated $(6,17,35)$. ENT die-off rates have been shown to be reduced in sand compared to water(23), and rates can differ between strains ENT from different sources seeded into sand and water(2). Growth has also been observed in sterilized and natural sands subjected to varied 
experimental conditions $(15,44)$. Predation and competition with the indigenous microbial communities adds an additional layer of complexity to these questions (10).

Since the majority of water quality violations stem from unknown sources of fecal indicator bacteria (9), observations of elevated concentrations of bacteria in upper intertidal beach sands have driven the hypothesis that sands may be a source of bacteria to waters during high tides, when waters come into contact with this relatively enriched reservoir of bacteria. This hypothesis is supported by water quality data collected at different beaches, including hourly observations of ENT concentrations that were significantly higher during high-tides at a subtropical recreation beach (41), and a meta-analysis of California water quality data that showed water samples collected during higher spring tides have significantly greater concentrations of Enterococcus and a higher probability of exceeding the single sample maximum of $104 \mathrm{CFU} / 100 \mathrm{~mL}(3)$.

This study investigated spatial and temporal variation of enterococci in water, intertidal sand and high-tide sand over a three-month period of predominantly dry weather at a beach in Massachusetts thought to be impacted by nonpoint source pollution. In the northeastern U.S. the bathing season is relatively short, and water and air temperature, precipitation and humidity often change dramatically between May and September and from year to year. By collecting a suite of environmental variables, we documented which conditions in the environment were significantly correlated to elevated enterococci in water and in sands. Best-fit multiple linear regressions were constructed using the environmental variables, and could successfully explain more than half of the observed variation in enterococci in water and in sands. The results emphasize that tides are important and predictable contributors to the amount of ENT at beaches. During dry weather, 
tides are the primary rewetting mechanism sustaining culturable ENT populations in high-tide sands, and tidal stage also appears to modulate the abundance of enterococci within the intertidal.

\section{Methods}

\section{Data Collection}

Five sites along Provincetown Harbor (SI Figure 1) were sampled between 8am and 9am every Sunday, Monday and Tuesday from the end of May through the beginning of August, 2010. One liter of water was collected at each site by submerging an acid-washed, autoclaved 1L Nalgene bottle under water at mid-calf (approximately $30 \mathrm{~cm}$ ) depth. Duplicate samples of the wet sand were collected at the water line with 50mL Falcon tubes, and duplicate dry sand samples were collected with 50mL Falcon tubes from a fixed spatial location that was in the mean high tide line. The water temperature, salinity, dissolved oxygen, conductivity and turbidity were measured for each sample and currents, air temperature, winds, solar insolation and relative humidity data were collected at the pier from June $10^{\text {th }}$ to August $10^{\text {th }}$ (details, SI Section 2.1). Samples were transported on ice to the lab where the US EPA Method 1600 (36) was used to enumerate ENT per $100 \mathrm{~mL}$ water and was modified to enumerate ENT in sands. $500 \mathrm{~mL}$ of water were filtered and $2 \mathrm{~g}$ of raw sands were archived and frozen for subsequent DNA extractions (details, SI Section 2.2). DNA was extracted from all samples collected at the first, third and fifth site along the beach.

\section{Molecular Assays}

The Enterococcus qPCR assay used the same genus-specific 23S rDNA primers (19) used in the USEPA Draft Method A (37) but with SYBR rather than TaqMan-based chemistry for qPCR detection. Purified genomic DNA (ATTC E. faecalis) was used to construct the standard curve 
(details, SI Section 2.3). All DNA samples were subjected to an assay for the presence or absence of human fecal Bacteroides (Bernhard and Field, 2000, Santoro and Boehm) to determine whether the marker of human waste was present at the beach, and if so whether it could be predicted based on co-occurance with elevated CFU or qPCR measurements of Enterococcus.

Statistics

ENT CFU and qPCR cell equivalent (CE) abundance data were $\log _{10}$ transformed, after which samples approximated a normal distribution. Environmental data collected on 15-minute intervals were averaged on three timescales (averaged over previous $24 \mathrm{~h}$, averaged over $4 \mathrm{am}$ 8am, averaged over hour preceding sampling event) and checked for normality for comparison with ENT data. Environmental data collected along the beach were averaged and the daily mean was used. Pearson's correlation coefficients and stepwise selection of best-fit Multiple Linear Regression models were calculated using the statistical software JMP. Data visualization and one-way ANOVA tests for differences in tidal range, tidal stage, etc. were conducted using R. In all tests, $\mathrm{p}<0.05$ was the cutoff for significance.

\section{Results}

\section{Site characterization}

The ability of the harbor breakwater (SI Figure 1) to retain polluted water within Provincetown Harbor was considered, but the current profilers suggested this would be an unlikely scenario since the residence time of water within the harbor is less than a day. During sampling days over the summer, winds primarily blew from the southwest, water and air temperature increased over 
time, and salinity of water samples was found to be significantly linearly related to tidal level of water (SI Section 3.3 for detail).

Spatial distribution of ENT CFU in water, intertidal wet sand, and dry sand along the beach

ENT concentration in water and sand samples ranged from undetectable to hundreds of CFU/100mL in water and thousands of CFU per 100g dry-weight sand. Although the five sites along the beach were chosen in part to reflect the presence of different potential sources of FIB, including municipal stormwater pipes buried in the sands at two of the five sites that discharged within the intertidal, there was no significant difference in ENT between the five sites sampled along the beach in any of the sample types. A one-way ANOVA was used to test for significant differences between the five sites, and samples collected on the same day were treated as dependent samples. The difference in water ENT between the sites was not significant $(\mathrm{p}=0.77)$, nor were differences in wet sand ENT between sites $(\mathrm{p}=0.57)$, or differences in dry sand ENT between sites $(\mathrm{p}=0.16)$. Over the sampling season (Figure 1), dry sand was significantly more enriched in ENT than wet sand $(\log (\mathrm{ENT})$ dry sand mean $=2.11, \log (\mathrm{ENT})$ wet sand mean $=$ 1.70, paired t-test, $\mathrm{p}=0.02$ ), and wet sand was significantly more enriched in ENT than the $\log (\mathrm{ENT})$ water mean $=1.04, \mathrm{p}<0.001)$. Samples collected along the beach in water, wet sand or dry sand on any given day could exhibit great range in ENT concentrations, as can been seen in the standard error bars around the daily mean in Figure 1. There were seven days that had water quality violations (>104CFU/100mL), but rarely was more than one water sample in violation of the standard and only once were three of the five samples above the single-sample maximum. There was never a case when all water samples were above the limit and subsequently, there is no day where the along-beach mean exceeds the single sample maximum. 
Figure 1: Daily mean concentrations of ENT at the beaches of Provincetown Harbor. All ENT concentrations are plotted on a $\log 10$ scale. Peaks in ENT on June 1 and June 7 corresponded to precipitation.

A. Daily mean ENT CFU/100mL water are plotted with standard error bars, and compared to the results from the multiple linear regression model constructed using water temperature, wind speed, and water level.

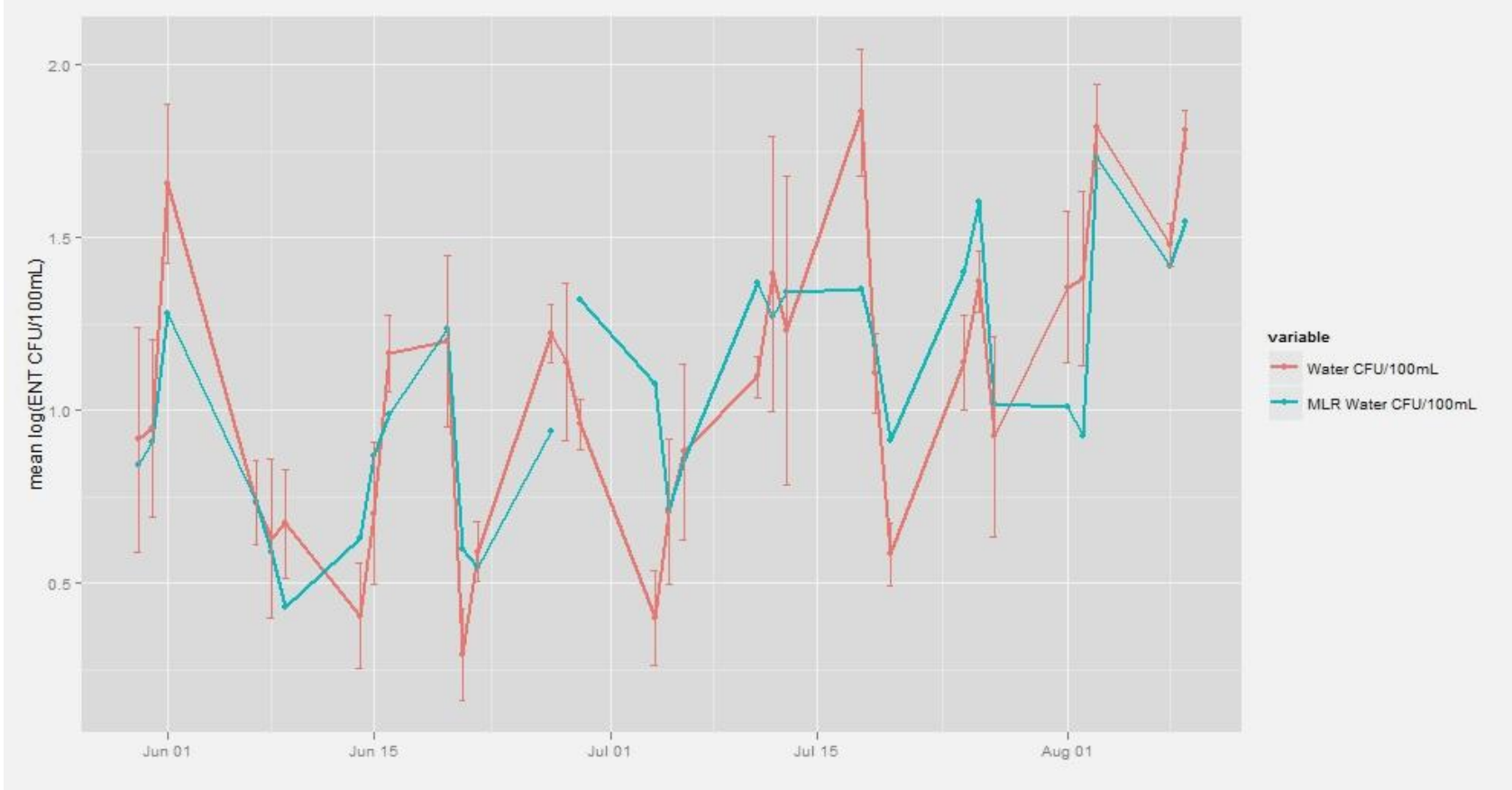

B. Daily mean ENT in wet sands sampled at the water line and dry sands sampled at the high-high tide line are plotted with tidal range, which was a significant predictive variable for the amount of ENT in dry sands.

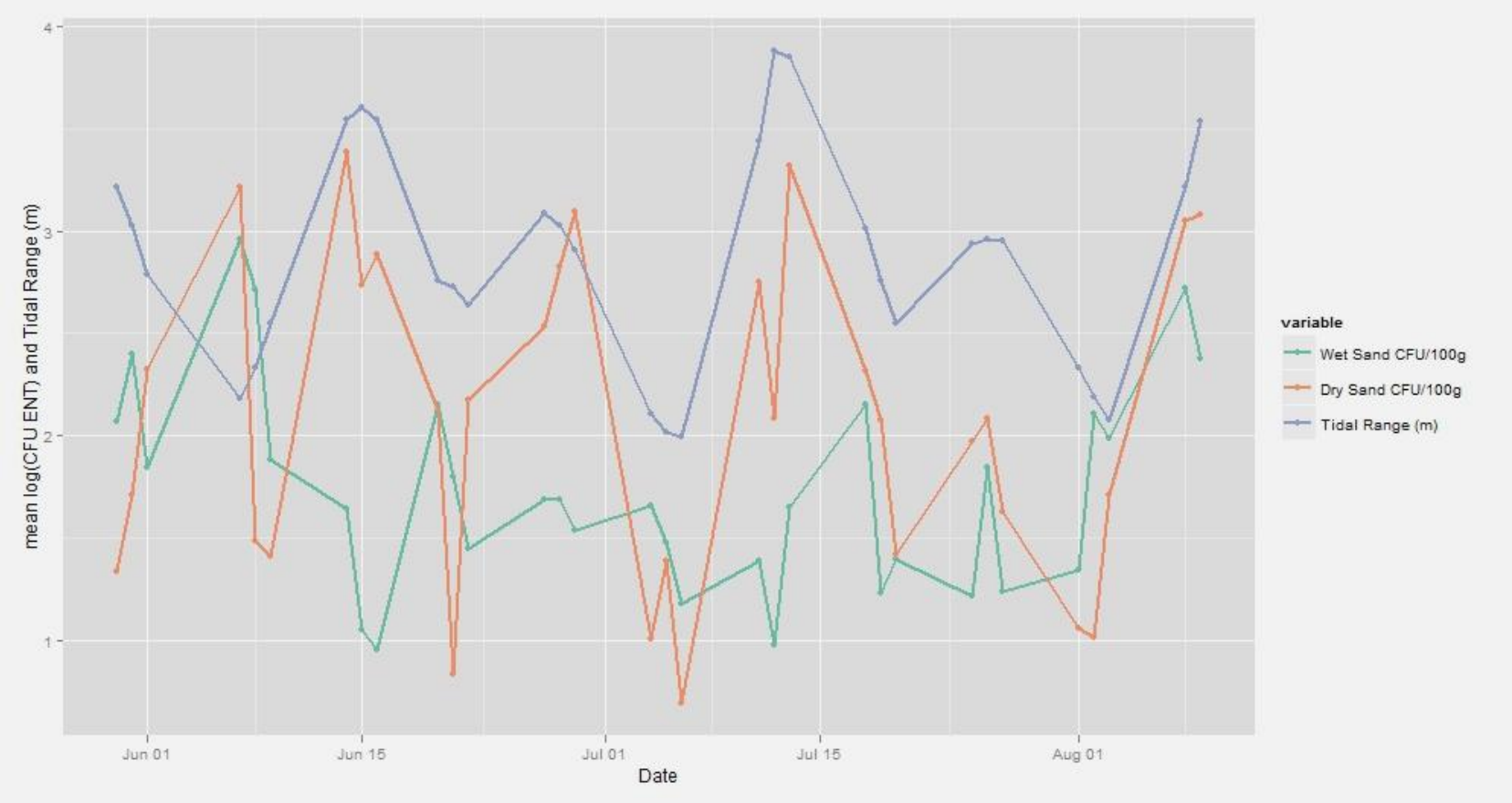


In dry sands, the daily along-beach average of the five samples was significantly negatively correlated to the variance of the five samples (Pearson's $r=-0.45, \mathrm{p}=0.01$ ) indicating that on days when higher amounts of ENT were observed in sands, the trend was not driven by a few patches of extreme ENT concentration. This trend between daily geometric mean and variance was directionally similar but insignificant in wet sand $(r=-0.25, p=0.16)$, and nonexistent in water $(\mathrm{r}=0.1, \mathrm{p}=0.58)$.

Figure 2: Characterizing the relationship between intertidal sands, moisture content and logENT per dry weight sand. Data collected from a transect across exposed intertidal sand show differences in moisture and ENT content range from the low-tide water line to the high-tide wrack line. The average logENT in sands is more strongly correlated to distance from water (Pearson's $r$ for all samples $=0.64$ and $p<0.001$ ) than moisture content of sample (Pearson's $r=$ $0.5234, \mathrm{p}=0.004)$, though both are significant.

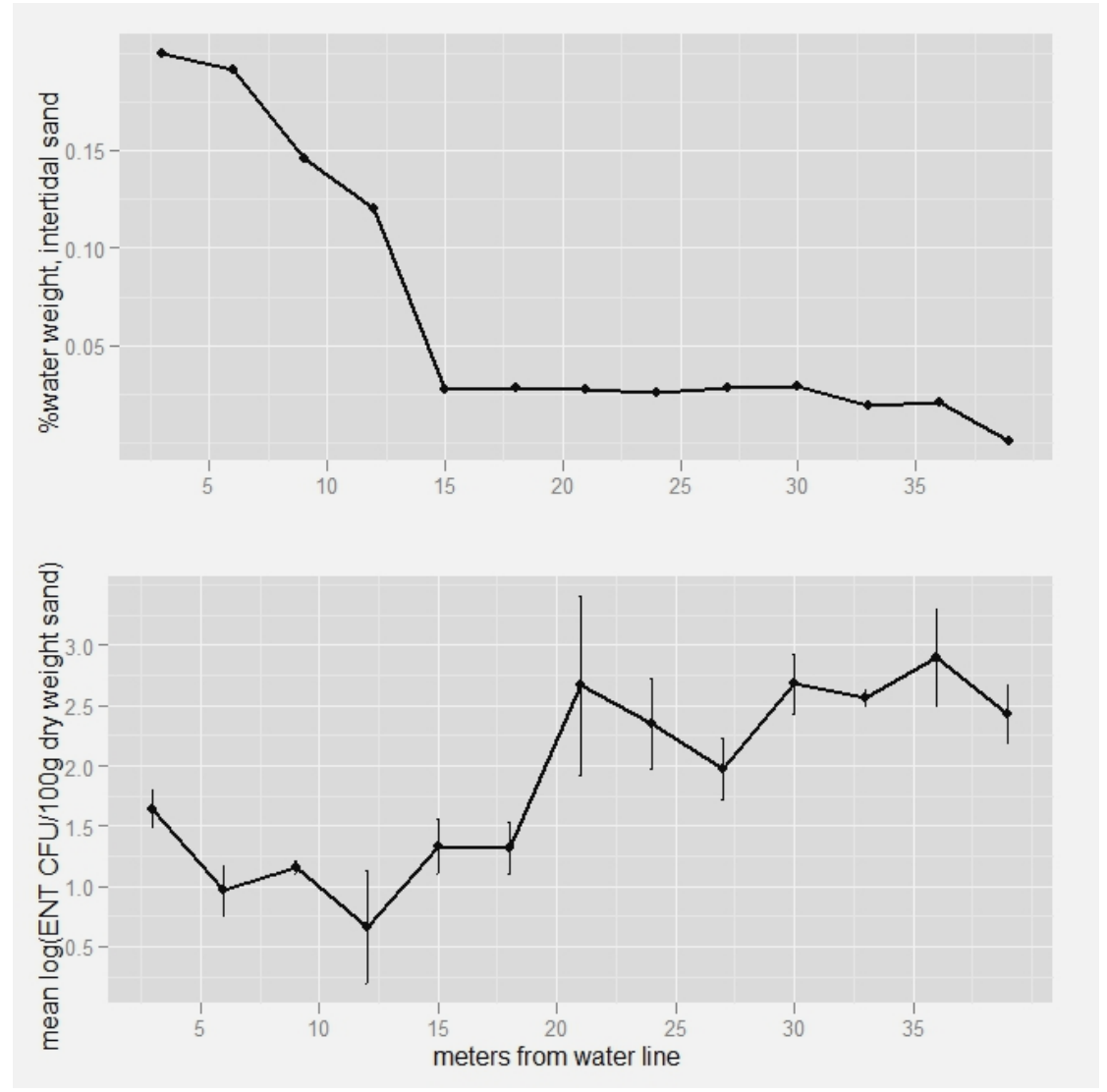


Spatial trends within the intertidal

The moisture content ( $\%$ water weight per $100 \mathrm{~g}$ sand) and ENT abundance along a detailed transect across the intertidal sands exposed at low tide are plotted in Figure 2. Some patchiness is observed, but overall the amount of bacteria in sands increases linearly over the exposed beach $\left(\mathrm{R}^{2}=0.65\right)$. The linear relationship is fairly strong, but the data could also be interpreted to suggest a demarcation between sand ENT populations corresponding to the sharp change in moisture content, with sands within $12 \mathrm{~m}$ of the low-tide water line having $10-20 \%$ moisture content and sands $>12 \mathrm{~m}$ having less than $3 \%$ moisture content and significantly more ENT (mean $\log (\mathrm{ENT} / 100 \mathrm{~g})$ in sands $<12 \mathrm{~m}=1.21$, in sands $>12 \mathrm{~m}=2.24, \mathrm{p}<0.001)$. This is consistent with the overall trend that during the summer, sands in the upper intertidal and above the high tide line host significantly more bacteria than wet sands in the lower intertidal that are frequently submerged.

\section{Environmental variables associated with the abundance of ENT in dry sand}

Daily mean ENT abundance in dry sand is significantly correlated to tidal range $(r=0.48$, $\mathrm{p}<0.0001)$. Over the sampled time series, the dry sands collected during spring tides had significantly higher mean ENT than sands collected during neap tides (Student's t-test, $\mathrm{p}<0.001$, distribution shown in Figure 3A). We hypothesize the primary mechanism by which sand is moistened during dry weather is from washup from high tides, and the greater tidal range of spring tides produced moister sand at the high tide line. The data support this hypothesis, as daily tidal range is significantly positively correlated to daily mean dry sand moisture content $(\mathrm{r}=0.57, \mathrm{p}<0.0001)$. ENT in individual samples of dry sands also was significantly related to moisture content in the sample, which ranged from $<1 \%$ to $4 \%$ (r=0.4, p<0.0001). ENT 
populations in high-tide dry sands were also correlated to $24 \mathrm{~h}$-averaged solar insolation $(\mathrm{r}=-0.42)$ and relative humidity $(\mathrm{r}=0.54)$, which are strongly inversely related to one another. These variables would influence the rate of moisture evaporation from sands, thus extending or curtailing the positive impact of tidal wetting on ENT populations.

\section{Environmental variables associated with the abundance of ENT in wet sand}

Daily mean ENT abundance in wet sand was negatively correlated to tidal range ( $\mathrm{r}=-0.21)$, and significantly related to environmental measurements of wind, including previous $24 \mathrm{~h}$ speed $(\mathrm{r}=0.36)$ and direction $(\mathrm{r}=0.68)$. Wet sand ENT was weakly negatively related to minimum air temperature $(\mathrm{r}=-0.31, \mathrm{p}=0.08)$ and weakly positively related to precipitation $(\mathrm{r}=0.32, \mathrm{p}=0.07)$ during the summer sampling season.

\section{Environmental variables associated with the abundance of ENT in Water}

In 2010, the daily mean culturable ENT in water along the beach was most significantly correlated to mean turbidity of the samples collected $(\mathrm{r}=0.74, \mathrm{p}<0.0001)$. Both the daily ENT and turbidity in water were correlated to significant wave height $(r=0.4,0.38)$ and measurements of $24 \mathrm{~h}$ average windspeed from the harbor $(\mathrm{r}=0.43,0.25)$ and from the airport $(\mathrm{r}=0.57,0.43)$. Temperature was also significantly correlated to ENT in water, including both the temperature of the water sample $(\mathrm{r}=0.45, \mathrm{p}=0.01)$, and air temperature at the time of sampling $(\mathrm{r}=0.36, \mathrm{p}=0.03)$. ENT CFU in water was not significantly correlated to ENT CFU in dry sand $(r=0.25, p=0.16)$ or ENT in wet sand $(\mathrm{r}=0.15, \mathrm{p}=0.4)$.

The results from the $8 \mathrm{am}-12 \mathrm{pm}$ hourly sampling showed that at finer temporal resolution there was still no significant difference in the distribution of ENT between sites. Surprisingly, water 
samples showed no significant decline in ENT over time (Table 1), as had been expected since exposure to UV was intensified as the morning progressed.

\section{Table 1: Results from hourly sampling along the beach around a high tide}

June 9, 2010

Time of sample:

$$
\begin{array}{r}
\text { 8:00 AM } \\
\text { 9:00 AM } \\
\text { (High Tide) 10:00 AM } \\
\text { 11:00 AM }
\end{array}
$$$$
\text { 12:00 PM }
$$

Water level

(ft.)

\author{
Tidal velocity \\ (ft/hr)
}

\author{
mean CFU \\ per $100 \mathrm{~mL}$ water
}

mean CFU

per $100 \mathrm{~g}$ wet sand

$\begin{array}{ll}6.77 & 0.82 \\ 7.88 & 0.44 \\ 8.12 & 0.14 \\ 7.46 & 0.58 \\ 6.22 & 0.76\end{array}$

115

126

281

136

116

Sampling took place as the water approached and then retreated during a high neap tide (maximum water level 8.2 $\mathrm{ft}$, tidal range of $7.5 \mathrm{ft}$ ). Even with increasing exposure to UV on this sunny, warm morning, bacteria in the water are highest during the flood and ebb tide, during which time the bacteria in sands are relatively lower. As observed in the along-beach transect (Figure 2), wet sands ENT concentrations increased across the intertidal. Although ENT concentrations were quite low, these data exhibit the same trend in variation of water quality with tidal stage (Figure 3B) with lower concentrations observed at high tide.

Correlation between cultured ENT and qPCR ENT cell equivalents (CE) in water, intertidal wet sand, and dry sand along the beach

Daily $\log (\mathrm{ENT}$ CFU/100mL) were positively correlated to daily $\log (\mathrm{qPCR} \mathrm{CE} / 100 \mathrm{~mL})$, with a Pearson's $r=0.38(p=0.03)$. This correlation falls into the range of the relationship observed between qPCR CE and CFU at other nonpoint-source polluted beaches (7). As was observed with ENT CFU in water, qPCR CE were also positively correlated to water temperature and maximum windspeed. However, unlike the CFU data the $\log (\mathrm{qPCR} C \mathrm{CE} / 100 \mathrm{~mL})$ were negatively correlated to qPCR CE in wet and dry sands $(\mathrm{r}=-0.28, \mathrm{r}=-0.53)$. The wet and dry sand $\log (\mathrm{qPCR}$ $\mathrm{CE} / 100 \mathrm{~g}$ ) were 2-3 orders of magnitude higher than the CFU data, reflecting the accumulation of dead cells, viable but non culturable cells, or naked DNA in the sands. Also, the wet and dry sands were strongly correlated to one another $(\mathrm{r}=0.77)$, a relationship not observed among 
culturable ENT. In this regard, the measurements based on DNA clearly were not representative of cultivable cells (SI Figure 4).

Spatially, there were no significant differences between the sites in the qPCR cell equivalents in water $(\mathrm{p}=0.30)$, wet sand $(\mathrm{p}=0.12)$, or dry sand $(\mathrm{p}=0.92)$. Although $\mathrm{qPCR}$ CE tended to have higher means during spring tides, the difference was not statistically significant (SI Figure 4).

Step-wise Multiple Linear Regression successfully utilizes environmental variables to describe ENT abundance in dry sands and in water

No linear combination of environmental variables could adequately predict a significant portion of the variation of ENT in wet sand, which likely reflects the fact that wet sand was not sampled at a fixed spatial location but over a range of the intertidal that corresponded to the location of the water line at 8am. However, the population of ENT in dry sand was fairly well explained by a combination of environmental variables that were collected at the meteorological station on the pier. The variation in the daily mean $\log (\mathrm{ENT})$ in dry sand could be described by a linear combination of tidal range and solar insolation in the $24 \mathrm{~h}$ prior to the sampling event $\left(\mathrm{R}^{2}=0.66\right)$, shown in SI Figure 6. Previous 24h relative humidity was also significantly correlated to dry sand ( $r=0.42$ with $\log (\mathrm{DS})$, also $\mathrm{r}=-0.61$ with $24 \mathrm{~h}$ solar insolation) but not included in the best-fit multiple linear regression due to co-linearity.

The daily mean $(\operatorname{logENT})$ in water along the beach could be predicted by a linear combination of three variables: water temperature (which increased over the course of the sampling period), water level, and $24 \mathrm{~h}$ average wind speed (which is likewise positively correlated to both $24 \mathrm{~h}$ relative humidity and the $\log (\mathrm{ENT})$ in wet sand), which produced an $\mathrm{R}^{2}=0.62$. This is in contrast to rainy periods, such as during the six weeks when preliminary samples were collected at one of 
the five sites in June and July of 2009, which had much higher ENT in water and sands (SI

Figure 3) and during which ENT concentrations could be explained by a linear combination of $24 \mathrm{~h}$ precipitation and air temperature $\left(\mathrm{R}^{2}=0.78\right)$.

Figure 3: Tidal impacts on ENT densities in water, intertidal wet sand, and dry sand. Boxplots show the $25^{\text {th }}, 50^{\text {th }}$ and $75^{\text {th }}$ percentile of the data as the lower edge, middle line, and upper edge of the box. The whiskers extend to the most extreme data point, if it is within $1.5 *$ interquartile range. If data points fall outside of this range, they are considered outliers and plotted as individual points.

A) Effects of Spring and Neap Tides: In the aggregate data collected May-August, water and dry sand samples collected during above-average tidal ranges (spring tides) had significantly higher daily mean ENT than samples collected during below-average tidal ranges (neap tides). Wet sands trended the opposite direction but were not significantly different. Units

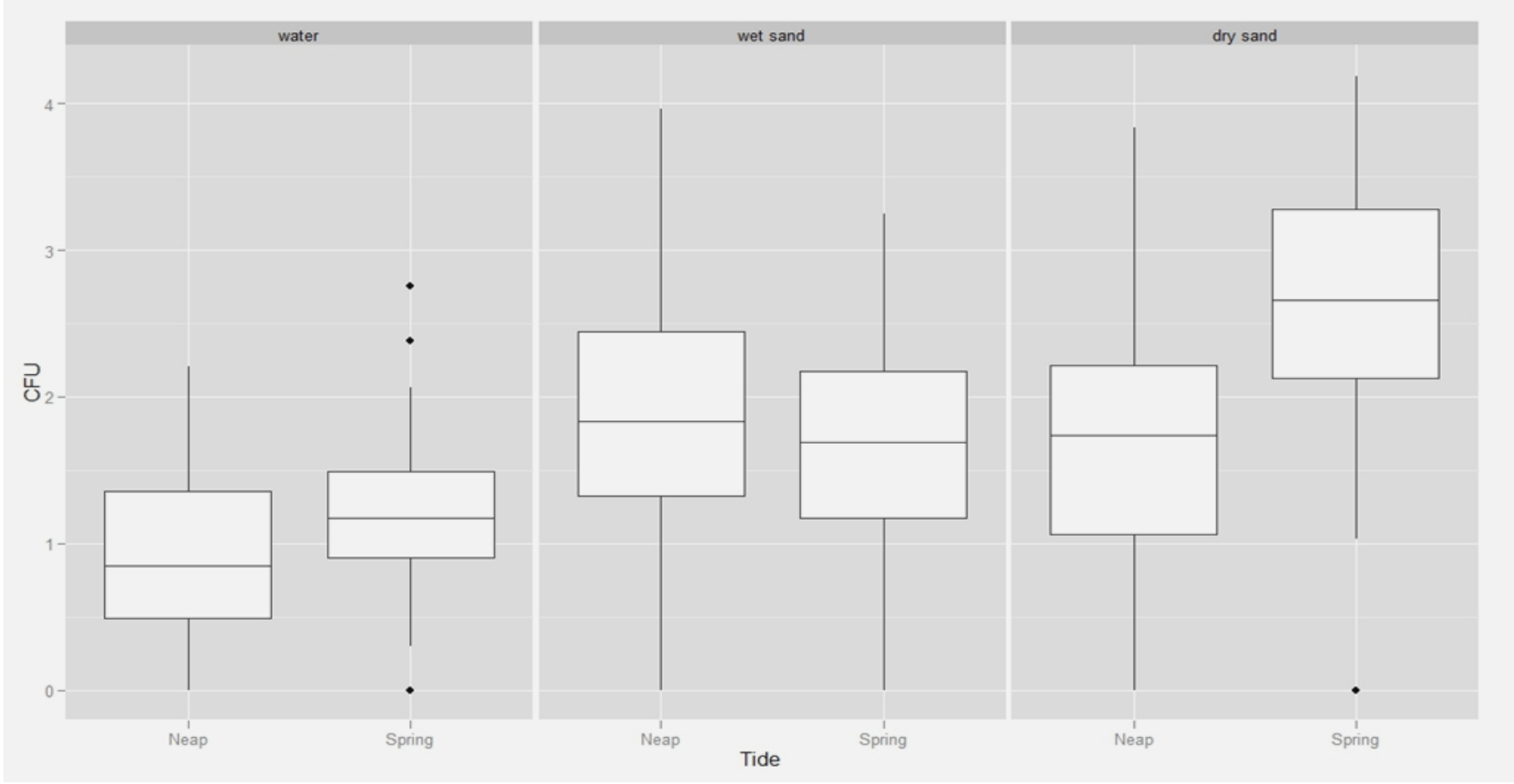


B) Effects of Tidal Stage: Samples were binned based on whether the 8am collection time coincided with a low tide, flood tide, high tide or ebb tide. Water samples collected during high tides had significantly lower mean ENT than samples collected during the flood or ebb tides $(\mathrm{p}<0.001)$. Wet sand samples collected during flood tides had the lowest concentration of ENT, which may be driven by mobilization of ENT into the water. Wet sand samples collected during ebb tides are elevated relative to flood, which may be the consequence of ENT drawdown from the high-tide dry sands. Dry sand samples collected during the ebb tide have significantly reduced mean ENT, which is consistent with a model that includes drawdown of ENT from high tide sands into the intertidal.
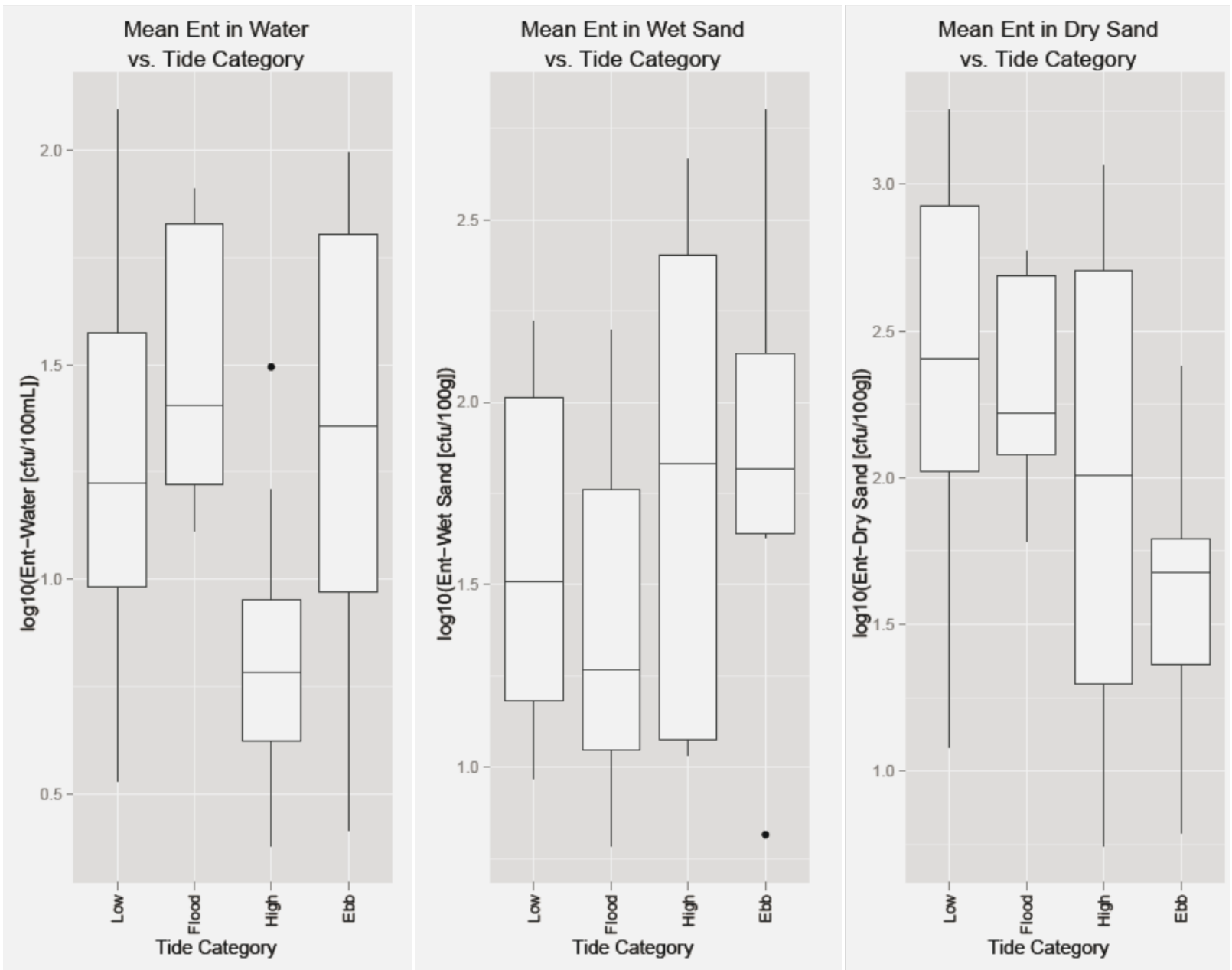
Variables selected for best-fit MLR suggest intertidal sand may contribute to variation observed in water

Including the daily concentration of culturable ENT in sands as potential predictive variables for the water quality step-wise selection process did not improve the final multiple linear regression model describing ENT in water. Furthermore, none of the variables associated with the bacteria in high dry sands (tidal range, moisture content, relative humidity, solar insolation) were included in the regression predicting ENT in water. However, two of the predictive variables that were included in the model were among the only variables associated with ENT in wet sand. The tidal level variable was based on water height at the time of sampling and essentially describes the spatial location within the intertidal where the water and wet sand sample were collected, which changed from day to day and more drastically from week to week depending on the tidal level at $8 \mathrm{am}$. Furthermore, the model included the variable $24 \mathrm{~h}$ wind speed which was also significantly correlated to ENT in wet sand. In order to examine whether there was a potential relationship between tidal level and ENT in water, wet sand and dry sand, all of the samples from the time series were binned based on where they were collected within that morning's tidal cycle (low, flood, high and ebb, with high and ebb defined as sampled $+/-1.5 \mathrm{hr}$ from predicted HT/LT). The results are illustrated in box-and-whisker plots (Figure 3B), and revealed significant patterns suggesting a mechanism for exchange of bacteria between sand and water in the intertidal.

Wet sands collected during flood tides had the lowest concentration of ENT, even though surveys of exposed intertidal sands showed that concentrations of bacteria in the intertidal zone increased from the low water line to the high tide line (e.g, Figure 2). Contrary to our hypothesis that the concentration of ENT in water would increase proportionally to the amount 
of bacteria in sands and result in a higher likelihood of exceedance events occurring during high tides, water samples collected during high tide had significantly lower concentrations of bacteria than samples collected during flood and ebb tides. ANOVA between total water samples grouped by tidal stage (low-flood-high-ebb) shows a significant difference between the means of these groups $(\mathrm{p}=0.0001$ ), and the Tukey HSD test shows more specifically that there are significant differences between flood and high $(\mathrm{p}<0.01)$, and between high and ebb $(\mathrm{p}<0.01)$, but not between any other combination of the groups in water.

The single day with simultaneous spatial and temporal sampling showed a trend similar to that observed amongst total samples grouped by tidal stage at the time they were collected. The concentration of ENT in water was higher in the first and final samples taken during the top of the flood and ebb tide at $8 \mathrm{am}$ and $12 \mathrm{pm}$ respectively, than it was in the samples taken during the slack water of the high tide, as shown in Table 1.

Turbidity data show suspended particles are also significantly higher during the flood and ebb tides within the tidal cycle

Turbidity measurements were very low at this site and generally at least an order of magnitude lower than the turbidity regularly observed at beaches, such as Santa Monica Harbor(18). However, turbidity data is also significantly distributed in the same pattern as was found with ENT in water in relation to tidal stage (ANOVA, $\mathrm{p}=0.04$ ). The Tukey HSD indicates that flood tide turbidity is significantly greater than the mean of each of the other groups $(\mathrm{p}<0.01)$, which is consistent with mobilization from sands, and also that ebb tide is significantly greater than high tide $(\mathrm{p}<0.05)$. Increased turbidity has been related to increased bacterial abundance in other 
systems $(6,20,26,35)$, but more often in relationship to storm events (18) or estuarine fluxes associated with very high turbidities (17).

Dry sands as an intermittent source of bacteria to the surfzone

The high-tide dry sands that are most enriched in ENT also show a distinct trend with tidal stage (Figure 3), with significantly less bacteria in sands sampled as the tide was ebbing, within hours of the dry sands being rewetted due to contact with the high tide (to a greater or lesser degree, depending on the tidal range). The dry sand data aggregated in this manner suggest that from ebb until the next high tide, the bacteria either regrow in the high tide sands, or the exposed sand is repopulated by people, birds, dogs, etc.

The low concentration in dry sands collected during the ebb tide combined with the observation of relatively higher concentration of bacteria in wet sands collected during the ebb tide suggests that there may be drawdown of bacteria from high dry sands to intertidal wet sands. The "same" wet sands (that is, sands collected in the same spatial zone of the intertidal) are more enriched in ENT as the water retreats from the dry sands than they are when the water approaches the high tide line.

Water quality violations of single-sample maximum (104CFU/100mL)

Single-sample water quality violations were detected in 10/153 samples, corresponding to violations occurring somewhere along the beach on 7 of the 32 days measured at $8 \mathrm{am}$. One of those days had egregious pollution of unknown source at the one site close to the wharf, where a tongue of black water stretched into the beach, having a turbidity of 25NTU as well as the highest concentration of bacteria observed in any single sample during 2010 (564 CFU/100mL). 
Excluding that particular violation as obviously not environmentally-derived, the effects of tides on exceedance events was tested by binning samples based on the rate of change in water level occurring when they were sampled. This metric incorporates information about whether the sample was collected during a surge (ebb/flood) or a slack (high/low) tide, as well as contribution of spring and neap tides since spring tides amplify the rate of change. Tides, thus characterized by rate of change in water level, influenced the probability of water quality exceedance events. A logistic regression $\left(R^{2}=0.88, p<0.001\right)$ of the 2010 data set using presence/absence of samples exceeding the single sample maximum as the dependent variable and binned rate of change $(<0.5,>0.5$ but $<1.0,>1.0$ but $<1.5,>1.5$ but $<2.0$, and $>2.0 \mathrm{ft} / \mathrm{hr})$ shows that the probability of having an exceedance event when absolute change in water level is $<0.5 \mathrm{ft} / \mathrm{hr}$ is 0.08 (high/low tides), and the probability increases logistically to 0.551 when it is $>2 \mathrm{ft} / \mathrm{hr}$ (spring ebb/flood tides).

Presence of HF marker in water samples

Unlike the Enterococcus spp. used for monitoring, Bacteroides are host-specific and thus can be used to track the sources of fecal pollution in the environment, in this case using a human-fecal (HF) marker (details, SI Section 2.3). None of the sand samples were positive for the HF marker, but 21/96 water samples (22\%) tested were positive for the HF marker, corresponding to 11/32 days having at least one water sample along the beachpositive for the HF marker, and 6/11 having two or all three water samples collected testing positive.

Three of the seven days with at least one single sample over the ENT limit also had a water sample that tested positive for HF marker, but notably there was no overall correlation between ENT abundance and the presence of the HF marker. Indeed, days that had all water samples 
testing positive for the HF marker had very low amounts of ENT in the water. Nine out of ten days sampled with tidal ranges $<8.5 \mathrm{ft}$ were positive for $\mathrm{HF}$ marker.

Submarine groundwater discharge is proposed as mobilizing mechanism responsible for observed distribution of ENT in wet sand and water, and presence of the HF marker

The effects of daily and fortnightly tidal oscillations on the distribution of ENT in surfzone water and sands (Figure 3), the freshening of seawater at lower tidal levels (SI Figure 5), and the temporal distribution the HF marker support the concept of a recirculation zone of submarine groundwater discharge within the intertidal. Groundwater was not measured in this study, but there is reason to believe it may play an important role in this system. Provincetown is underlain by a lens of fresh groundwater bounded laterally by the Atlantic Ocean and Cape Cod Bay; the lens is recharged by rainfall and treated sewage from the Provincetown wastewater treatment plant, and discharges 12.5 million gallons/day into the surrounding coastal waters (21).

Models and physical observations of tidal forcing on sloping beaches have documented the presence and importance of groundwater subterranean estuaries (29), which are composed of the fresh groundwater from natural and anthropogenic recharge and recirculating seawater from the intertidal. As seawater washes up on the beach it infiltrates the sands and mixes with fresh groundwater to create the subterranean estuary mixing zone that is identifiable by its intermediate salinity (Figure 4). The circulation cell that develops and flux of "estuarine" groundwater into seawater is tightly coupled to the tidal cycle, with net inflow occurring in the upper intertidal and net outflow in the lower intertidal, while discharge of fresh, unmixed groundwater occurs during low tides. The volume and cross-shore extent of the mixing zone varies as the tidal range extends and contracts with spring and neap tidal cycles (30), such that 
spring tides have greater mixing zones and greater total groundwater flux, because the flux is dominated by the recirculating seawater.

\section{Figure 4: Schematic of subterranean groundwater estuary}

Groundwater exchange is separated into density-driven circulation (below the low tide line) and tidally-driven circulation, with freshwater discharge occurring at the low tide water line. The estuarine mixing zone develops into a circulation cell with net inflow of water in the upper intertidal and net outflow in the lower intertidal. When the intertidal zone contracts (high tides are lower and low tides are higher) during neap tides, the mixed zone contracts as well resulting in less seawater recirculation through the subterranean estuary. The schematic is modeled after results from Robinson et al., 2007. Red stars indicate the section of the intertidal where the highest mean ENT occurs in sands and water at Provincetown. Note similarity to theoretical maximum inflow/outflow pattern.

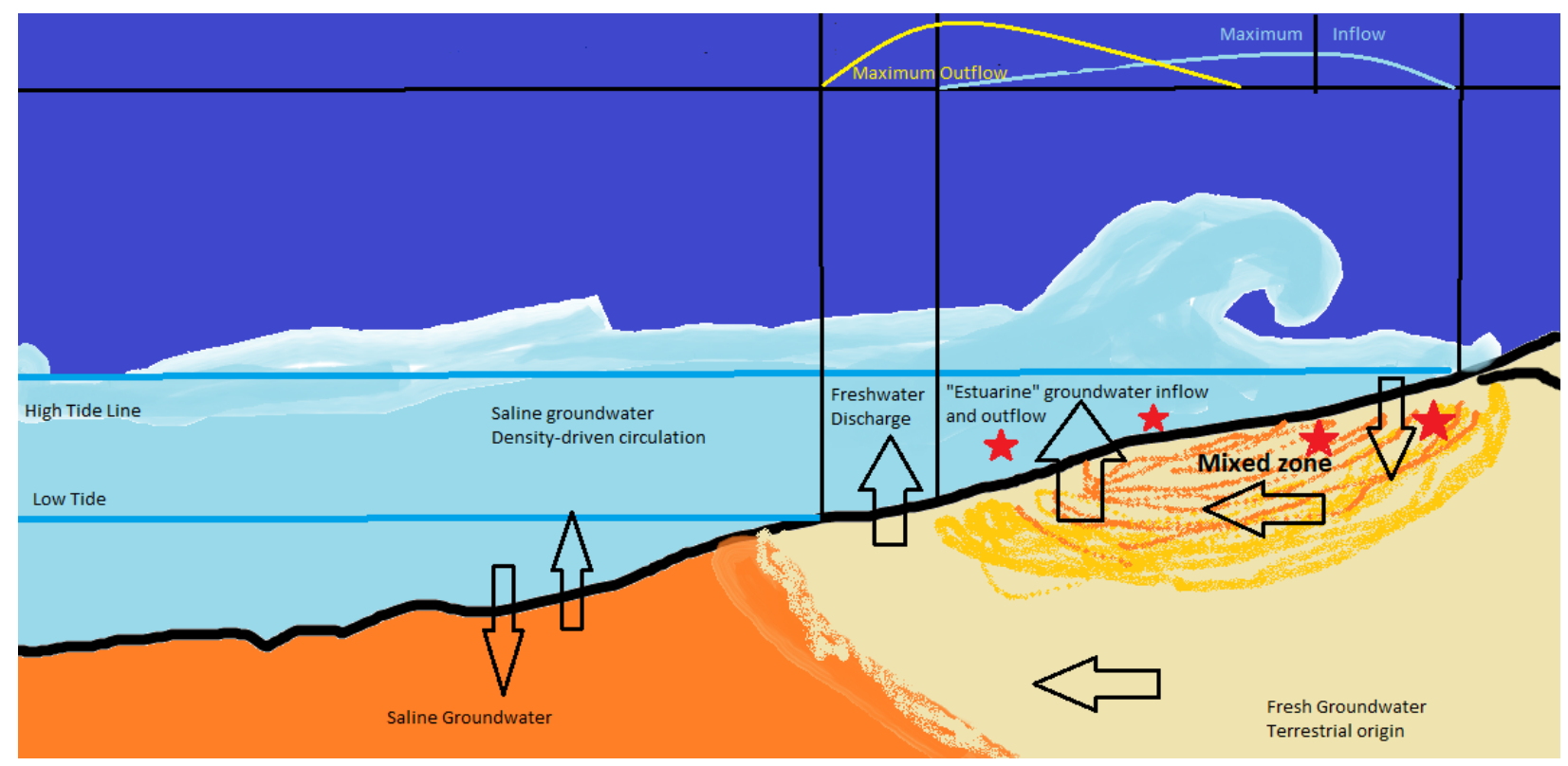

The data collected in 2010 show that salinity is strongly linearly related to water level, with samples collected at low tides being fresher and samples collected in the middle of the intertidal having intermediate salinities. ENT abundance in the water column is not correlated with salinity, and so contaminated groundwater itself does not appear to be the primary source of ENT at the beach. However, ENT abundance and turbidity in waters are both maximal at mid-to-low intertidal water levels, the same levels where maximum flux from the mixing zone would be expected to result in strongest mobilization of ENT and particles from sands. Likewise, ENT is highest in wet sands in the upper intertidal, where maximum inflow would occur. The ENT and 
turbidity signatures in water are significantly greater during spring tides, which would be expected as seawater recirculation and groundwater fluxes increased. Salinity signatures in the lower intertidal are slightly higher during spring tides, which also supports the concept of an increased mixing zone in the intertidal.

The corollary is that the smaller tidal range associated with neap tides would be characterized by lesser groundwater flux and a smaller mixing zone. The salinity data support this as the subset of samples collected during neap tides have a greater rate of change and stronger linear relationship to water level $\left(\mathrm{R}^{2}=0.80\right)$. If the HF marker is a signature of contaminated (via sewage discharge or leaking septic systems) fresh groundwater, then we may be detecting it during neap tides as a consequence of a stronger fresh water signal due to the reduced mixing zone. Other studies have documented a neap tide phenomenon where the flux of fresh, terrestrial groundwater constitutes a greater relative percentage of the total flux; since the terrestrial groundwater had been contaminated by septic systems, this resulted in increased concentrations of nutrients in the surfzone during neap tides (8). Curiously, although the groundwater samples collected by de Sieyes et al. were enriched in both ENT and nutrients, only the nutrient signal was detected in coastal waters.

In these data from Provincetown, it is striking that the HF marker was so consistently recovered from surfzone water samples collected during below-average tidal range $(<8.4 \mathrm{ft}, 90 \%$ positive $)$ regardless of ENT abundance, and may indicate that contaminated groundwater reaches the beach but is not associated with exceedance of the water quality standard. 


\section{Discussion}

Upper intertidal sands are enriched in ENT relative to water, and abundance over time is strongly influenced by moisture availability

As other studies have shown at beaches in Florida (1, 5), California (43), and along the Great Lakes(39, 40), beach sands at Provincetown are enriched in ENT relative to the water, and the average concentration of ENT in high-tide sands is comparable to concentrations documented in these other environments (on average, greater than $10^{2} \mathrm{CFU} / 100 \mathrm{~g}$ and ranging into $\left.10^{3} \mathrm{CFU} / 100 \mathrm{~g}\right)$. This presents the possibility that beachgoers who are digging in or being buried in sands may increase their risk of gastrointestinal illness, as has been observed in epidemiological studies of beach sand exposure (16). This study illustrates how temporal and seasonal trends can contribute to favorable environments for ENT at beaches, and suggests that bacteria can be entrained from the upper intertidal and subsequently influence water quality. Reducing the direct input of fecal bacteria to sands when possible, such as by removing animal waste before it is rapidly distributed by foot traffic (42), should be recommended to protect water quality and recreater health.

ENT populations in high-tide dry sands that are rarely submerged are strongly, positively correlated to the moisture content of sands, which in this dry sampling season were tightly coupled to wetting from extreme spring tidal ranges. As moisture content decreased following spring tides and in the absence of rainfall, the abundance of culturable ENT decreased as well. Although many studies have documented the sensitivity of E. coli to moisture content of sands, ENT has often been described as resistant to dessication and/or insensitive to moisture content. In part this is due to observations from microcosm experiments that found inactivation of ENT 
no different in wet and dry sands $(15,23)$. In a survey of ENT in sands and waters conducted over a full day at Lover's Point in CA, the moisture content of all sand samples collected hourly from dry and wet sand ranged from $<1 \%$ to saturated at $19 \%$, and over this range moisture content was negatively correlated to abundance of ENT in the sand sample. Several studies have documented a similar range of moisture content and ENT densities of dry and intertidal sands at different field sites, and similarly drawn conclusions that moisture content is either negatively (27) or not correlated (28) to ENT abundance in sands, observations that are upheld by our intertidal sampling transect and overall observations that dry sands are enriched in ENT relative to wet sand. However, the data presented here represent the first field sampling strategy to captures the small variations in moisture content in dry sands over weeks and months due to tidal wetting. Considering that ENT has been shown in lab experiments to initially decrease as moisture content in sands decreased, and then to regrow with simulated tidal wetting (44), it is not surprising that significantly higher amounts of enterococci are recovered from dry sand field samples during the times that they have been subjected to tidal wetting. The strong, significant relationship that we observe between ENT in high-tide sands and moisture content confirms the contribution of this variable to ENT persistence at beaches.

Variation of ENT in sands and water can be described by multiple linear regression models

The multiple linear regressions describe more than half of observed variation of the mean ENT at the beach, but are not predictive of individual exceedance events during the sampling season (as means were never above the single sample limit). The utility of these models is the insight they provide into how bacterial abundance in water at this beach relates to the natural environment and changes over time. Overall, the data from 2010 demonstrate the importance of tides during dry weather, and can be contrasted to the limited data set collected in 2009 (SI Figure 3), when 
stormwater dominated the ENT signal. Temperature was included in both wet and dry weather water quality models, but in these cases warmer temperatures were associated with increased ENT. This is in contrast to many studies that have documented increased ENT inactivation with higher temperatures $(22,26,33)$. While it may be the case that warmer temperatures are optimal for ENT in this temperate environment, in this region temperature steadily increases over the summer and may actually be indicative of increasing human impact at the site (more visitors, boaters, bathers, etc.) over the course of the summer. Unfortunately we do not have metrics to quantitatively test that alternative.

It is worth noting that turbidity was not included in the 2010 water quality MLR because it introduces collinearity with other variables. In terms of our goals of discovering how conditions in the environment impact ENT in the surfzone, it was preferable to exclude it as a variable from the step-wise selection. However, in terms of rapidly determining the likelihood of an exceedance event, it is very useful. A linear regression of daily mean $\log (\mathrm{CFU} / 100 \mathrm{~mL})$ with turbidity alone produces a respectable and significant $\mathrm{R}^{2}=0.54$. This was surprising because in contrast to some coastal systems where turbidity ranges vary greatly, waters at this site are never visibly turbid and all normal turbidity measurements were <4 NTU; nevertheless, the trends are highly significant. Turbidity is also easy to measure at the time of sampling and could be monitored autonomously, which may be a means of providing a rapid early assessment of water quality in dry weather.

These data sets are prime examples of the substantial temporal and interannual variability at this site, and more high-frequency monitoring data is needed to fully capture its effects. Eventually, larger datasets may train more robust predictive models, such as those currently operating at beaches on the Great Lakes (25) which utilize similar meteorological and hydrological predictive 
variables. These data show that even though ENT measurements continue to govern closure decisions, they may be routinely biased by tides and other environmental factors.

The HF marker was recovered from water samples, but was not correlated to any measure of ENT

Provincetown is considered to be impacted by nonpoint source pollution, which at any given time may include fecal matter from birds (pigeons at the beach, and cormorants on the breakwater), dogs which are routinely present on the beach and swimming in the water, boats which possibly discharge waste illegally in the harbor, and perhaps improperly maintained septic systems among the $66 \%$ of residents opting to remain on septic systems despite the sewering of the town in 2003 . The abundance of potential nonpoint sources likely contributes to the weak relationship between culturable and qPCR estimates of ENT in the water, as has been observed in other nonpoint source, single-beach studies (7). The absence of the HF marker in sands and the disassociation between the HF marker and enterococci abundance in water is not in itself surprising, since other studies have shown that waters polluted with ENT violations stemming from urban runoff can be uncoupled from the presence of the $\operatorname{HF}$ marker $(31,32)$. Likewise, experiments have shown the marker can decay more quickly in seawater than Enterococcus DNA (38). It is surprising that the HF marker repeatedly occurs during neap tides, suggesting that human fecal contamination is transported to the beach through groundwater but is uncoupled to the proliferation of ENT in the intertidal zone. The health risk associated with groundwater at this site is unknown but deserves consideration. We present one possible mechanism that could explain ENT and HF marker distribution, and which could be tested in the future by quantifying groundwater fluxes, examining the groundwater salt budget to determine whether there is a submarine estuary feature, and to quantifying the microbial risk associated with groundwater. 
Acknowledgements: E.H. was supported by a student research grant from the Woods Hole Coastal Ocean Institute, and funded by grants to the Woods Hole Center for Ocean and Human Health (NSF OCE 0430724, NIHP50ES012742, and NSF OCE 0911031). Thanks to the Provincetown Center for Coastal Studies and Dr. Amy Costa for making laboratory space available for sample processing. 


\section{Chapter 5: Supplemental Information}

\section{Site Description}

\subsection{SI Figure 1: Map of Macmillan Wharf and Provincetown Harbor, MA.}

Provincetown, MA is located on outer Cape Cod, which is a narrow arm of land composed of permeable glacial sediments that extends into the Atlantic. The five sites sampled in 2010 in Provincetown Harbor are shown with yellow pushpins, and sites 1 and 4 correspond to sites (333 Commercial St. and Johnson St., respectively) monitored by Barnstable County.
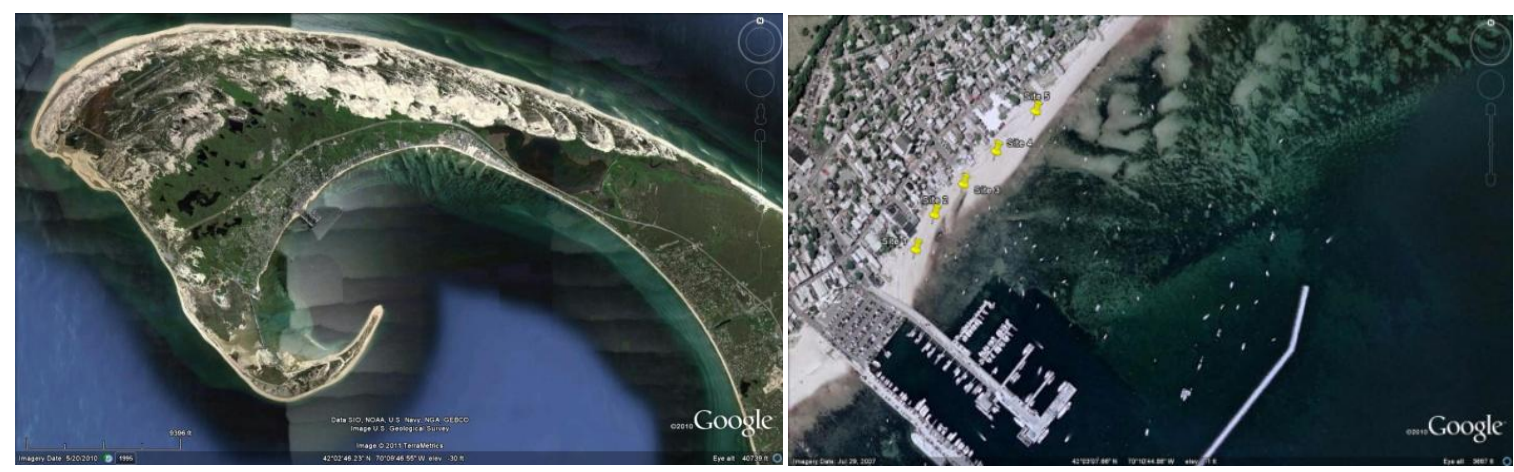

1.2 Historical wet and dry weather water quality violations documented through routine monitoring: Prior to 2010, monitoring data had shown that $58 \%$ of bacterial exceedance events measured by the health department along this stretch of beach ware associated with storm events (wet weather), but $42 \%$ occur with unknown bacterial sources during dry weather, leading to the selection of this site for further study. Based on the county monitoring data collected between 2003 and 2011, 2010 had above-average ENT for the site and below-average standard deviation. The decrease in standard deviation may indicate there has been an increase in point-source pollution (Whitman et al. 2011) in the harbor since sampling began in 2003. 
1.3 Mean water level and characterization of the tides: Provincetown has semi-diurnal tides with a meso-tidal range $>2 \mathrm{~m}$ but $<4 \mathrm{~m}$. Mean high tide water level is $2.87 \mathrm{~m}$ and mean high-high tide is $3 \mathrm{~m}$, relative to mean low water $(0 \mathrm{~m})$. Shown below is an example of the tidal oscillations within a week at the site.

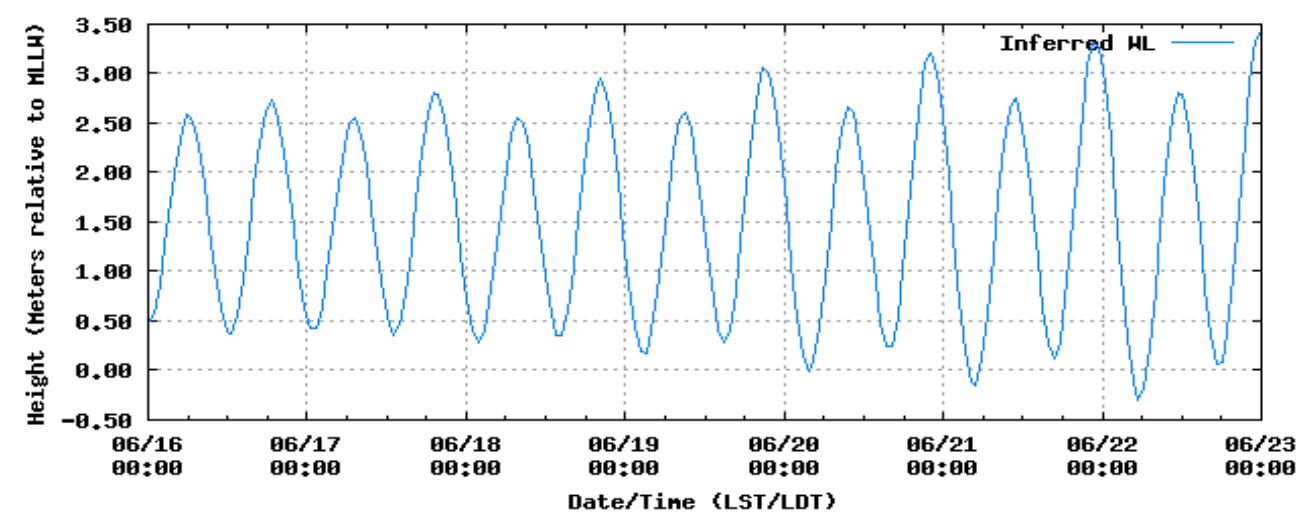

\section{Methods}

\subsection{Sampling protocol}

2.1.1 Hydrological and meteorological variables: Two acoustic Doppler current profiler (ADCP) meters were deployed from June 10 to August $10^{\text {th }} 2010$, inside and outside the harbor breakwater, to measure alongshore currents. A meteorological station was deployed on the Harbor pier to record 15-minute interval air temperature, solar insolation, relative humidity, wind speed and direction. Precipitation data were recorded two miles away at the Provincetown municipal airport and accessed through the NOAA's NCDC Climate Data Online (www.ncdc.noaa.gov/DCO/cdodata.cmd).

2.1.2 Environmental variables: As each sample was collected in the field, the ambient water temperature, salinity, dissolved oxygen and conductivity were measured with a YSI sonde. Air temperature was measured with a handheld thermometer, and turbidity determined with a turbidometer. 
2.1.3 Enumeration of ENT from Water: All samples were packed into a cooler with ice for transport back to the lab, where they were analyzed for ENT within six hours, via membrane filtration on mEI media as described in the US EPA Method 1600 (36). A blank sample of 50mL sterile phosphate-buffered saline solution was filtered and incubated each day as a negative quality-control. Water samples were inverted by hand before $100 \mathrm{~mL}$ was withdrawn for membrane filtration and culture on mEI plates. A second aliquot of $500 \mathrm{~mL}$ was filtered onto Durapore $0.2 \mathrm{um}$ filters which were subsequently folded with the sample facing inward and frozen in a $2 \mathrm{~mL}$ microcentrifuge tube for DNA extraction.

2.1.4 Enumeration of ENT from sands: The US EPA Method 1600 (36) was modified to assess enteroccoci in sand samples. Duplicate sand samples collected from a single site were combined in the lab and thoroughly mixed with a sterile plastic spoon. From this homogenized sand sample, $25 \mathrm{~g}$ was weighed out, returned to a Falcon tube, amended with $30 \mathrm{~mL}$ of sterile phosphate-buffered saline solution, and shaken vigorously by hand for two minutes. Particulate was allowed to settle for a minute before $10 \mathrm{~mL}$ of supernatant was withdrawn for membrane filtration and culture on mEI plates. The CFU observed for $10 \mathrm{~mL}$ were considered representative of $1 / 3$ of the ENT that could be released from the weight of sand measured in the tube. Later, CFU were normalized per dry weight of the sand based on the amount of water evaporated from an aliquot of the homogenized sand sample over $12 \mathrm{~h}$ at $104 \mathrm{C}$ in a muffle furnace. Organic content was also calculated for a subset of the samples by heating at $450 \mathrm{C}$ in the muffle furnace for five hours. Additionally, $2 \mathrm{~g}$ from the homogenized sand sample were stored in $2 \mathrm{~mL}$ microcentrifuge tubes and frozen for subsequent DNA extraction. 
2.1.5 Detailed intertidal transect: A detailed transect was collected across the intertidal at low tide. From the water line, surficial sand was collected every three meters until reaching the high tide line, spanning a total distance of 39 meters. Six Falcon-tube cores were taken from each transect location, and randomly combined into two homogenized samples that were analyzed for ENT abundance, as described in the previous section.

\subsubsection{Detailed spatial and temporal sampling: To document the spatial and temporal} variability associated with samples taken along the beach and over time, on one morning a team of volunteers collected samples at all five sites simultaneously on the hour from 8 am to $12 \mathrm{pm}$.

2.2 DNA Extractions: DNA was extracted from sands using the MoBio Soil DNA Extraction kit, which has previously been found to have a low recovery rate but a high quality DNA product that has minimized the presence of potential PCR inhibitors (14). DNA was extracted from water samples collected on the filters using a hot lysis buffer/bead beating method as described previously (12), and nucleic acids were precipitated with 0.6 volumes of isopropanol, recovered through centrifugation, air dried, and resuspended in 50uL sterile milli-Q water for use in PCR.

\subsection{Molecular Assays}

2.3.1 Calculating qPCR ENT Cell Equivalents (CE): The starting quantity of DNA in environmental samples was calculated based on the linear regression of a five-fold dilution series of standard E. faecalis genomic DNA. A dilution series of the standards was made for every qPCR plate, in which the starting quantity of DNA in the first standard was quantified with a nanodrop spectrophotometer, and then the freshly made dilution series was plated in technical duplicates on the plate. Environmental samples 
were run in technical triplicates, and the starting quantity in environmental samples was determined based on the regression of the triplicate mean starting quantity with the standard dilution series. Reaction conditions are described in (14). As a measure of quality control, environmental sample means were only considered acceptable if there was $<1 \mathrm{C}_{\mathrm{t}}$ standard deviation among triplicates. Duplicate no-template negative were run on every plate with the master mix, and environmental samples within $3 C_{t}$ of the negative control $\mathrm{C}_{\mathrm{t}}$ were considered below the detection limit. The qPCR melt curve was used to assess run-to-run consistency of the PCR product. The mean amount of starting quantity target DNA reported for samples was then divided by 3.6fg (DNA/E. faecalis genome) to estimate the amount of DNA per $1 \mathrm{uL}$ template DNA. CE/uL were then scaled to the total number of microliters eluted per sample (i.e. $100 \mathrm{uL}$ eluted per $2 \mathrm{~g}$ sand), and further scaled for comparisons of CE per $100 \mathrm{~mL}$ water or $100 \mathrm{~g}$ sand.

\subsubsection{Testing samples for extraction efficiency, inhibition: A subset of samples were spiked} with pGEM plasmid to estimate the recovery of DNA through the extraction protocol as well as inhibition of PCR chemistry, as described previously (14). In brief, pGEM was added with the lysis buffer during the first step of the extraction protocol for sands, and it was pipetted directly onto the filter before the addition of lysis buffer for the water samples. Based on the pGEM results, we estimate that inhibition reduced the reported starting quantity of ENT in sand by less than $10 \%$, and reduced the reported starting quantity of ENT in water sample by less than $30 \%$. Because the USEPA considers a reduction in amplification "significant inhibition" if it corresponds to a reduction that is $>3 \mathrm{C}_{\mathrm{t}}$ and our reductions were always $<3 \mathrm{C}_{\mathrm{t}}$, we chose to present our data without using a multiplicative factor correcting for DNA not reported due to inhibition, or for DNA 
presumably not recovered during extraction. This choice thus certainly under-represents the total amount of Enterococcus $\mathrm{CE}$ in the environment but was made to facilitate comparison of our results with results from studies using the newer USEPA method.

\subsubsection{Comparison of SYBR and TaqMan detection in ENT qPCR Assay. This work was} well underway before the U.S. E.P.A. published the draft method A for qPCR detection of Enterococcus, which uses different chemistry to detect PCR product (37). In the draft method, salmon sperm is incorporated as an exogenous standard to measure inhibition. To compare the sensitivity of SYBR and Taqman, a subset of water samples were randomly selected to compare our qPCR protocol with the EPA's Taqman protocol. No significant difference between SYBR and TaqMan chemistry was detected (Student's t-test, $\mathrm{p}<0.01$ ). The variability observed in the starting quantity in ENT DNA in environmental samples run with SYBR and TaqMan was comparable to that observed in repeat runs of the same samples with the same chemistry.

\subsubsection{SI Figure 2: Starting quantity of standard DNA detected with Taqman and} SYBR not significantly different, although amplification begins at a later $\mathrm{Ct}$

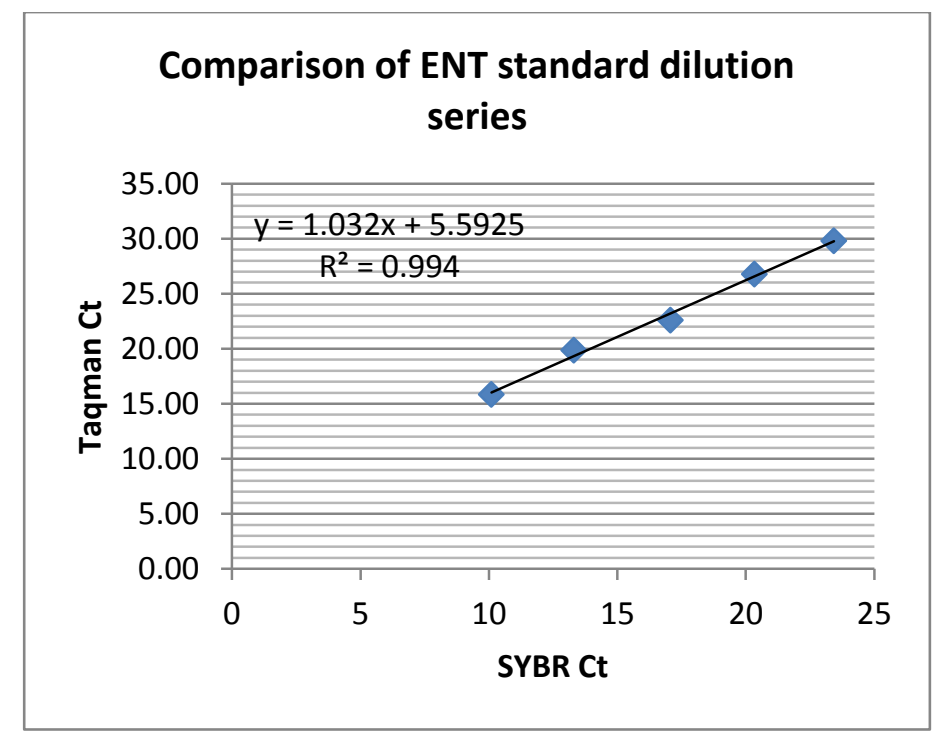


2.4 Human Fecal Bacteroides (HF Marker) PCR Assay: The human fecal Bacteroides endpoint-PCR assay (Bernhard and Field, 2000) was was used to test water, wet sand and dry sand for the presence of the human fecal marker. All samples were run with a positive PCR control reaction using purified genomic DNA (ATCC Bacteroides vaginalis) and a DNAtemplate free negative control.

2.5 Multiple Linear Regression Model Selection: Two multiple linear regression models were built using step-wise selection to predict the dependent variable of mean ENT in water, and to predict the dependent variable mean ENT in dry sand. All variables collected during sampling as well as time-averaged environmental variables form NOAA and from the instrument deployment at the site were offered as potential predictive variables. For water, daily ENT abundance in sand was also offered as a potential predictor and visa versa. The models were selected based on highest adjusted $\mathrm{R}^{2}$, acceptable distribution of residuals, and minized multicollinearity. Variance Inflationary Factors were calculated to control for multicollinearity and all variables included in the model had VIF $<2$.

\section{Results}

3.1 Preliminary data collected in $\mathbf{2 0 0 9}$ were strongly impacted by wet weather. As we observed in the 2010 data, there was a significant difference between the mean ENT in water, wet sand and dry sand and the pattern was the same. However the impact of runoff can be seen as mean ENT was elevated in all sample types in 2009 compared to ENT in 2010. 
SI Figure 3: Comparing the same period in July, mean ENT in water, wet sand and dry sand was significantly higher in 2009 ( $n=12$ days) than was observed in $2010(n=15$ days)

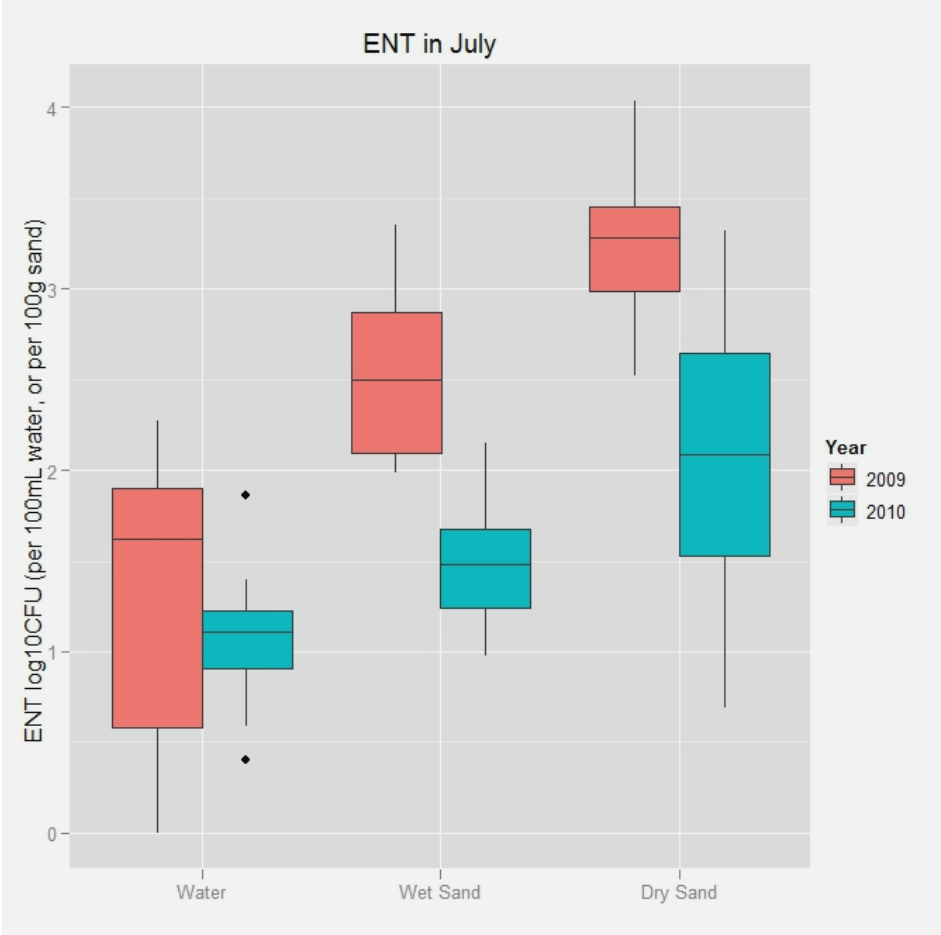

3.2 QPCR Results: Comparison of ENT CFU and qPCR CE distribution in water, wet sand and dry sand (SI Figure 4) shows that sands are significantly higher than water. While the mean qPCR CE is an order of magnitude greater than mean CFU, the mean qPCR CE in sands is 34 orders of magnitude greater than the CFU in sands. Samples have been binned by tidal range, showing similar trends of higher mean ENT during spring tides, but the difference was not statistically significant. Also in contrast to the CFU data, there was no significant difference in qPCR CE binned by tidal cycle. 
SI Figure 4: Distribution of qPCR $\log 10(C E)$ in water, wet sand and dry sand, binned by whether samples were collected during spring or neap tides. Not corrected for loss during extraction.

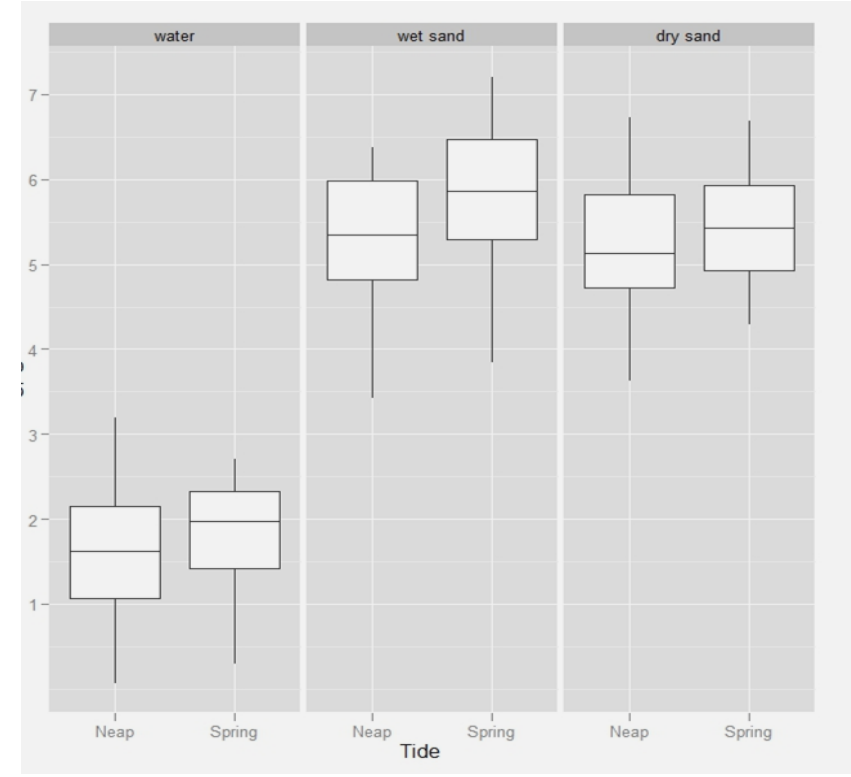

\subsection{Characterization of Environmental Parameters relevant to bacteria}

SI Figure 5: Salinity, water temperature and wind speed and direction were each related to ENT CFU in water and wet sandsSalinity:

A) Water collected at low tidal levels was fresher than water collected at high tide levels.

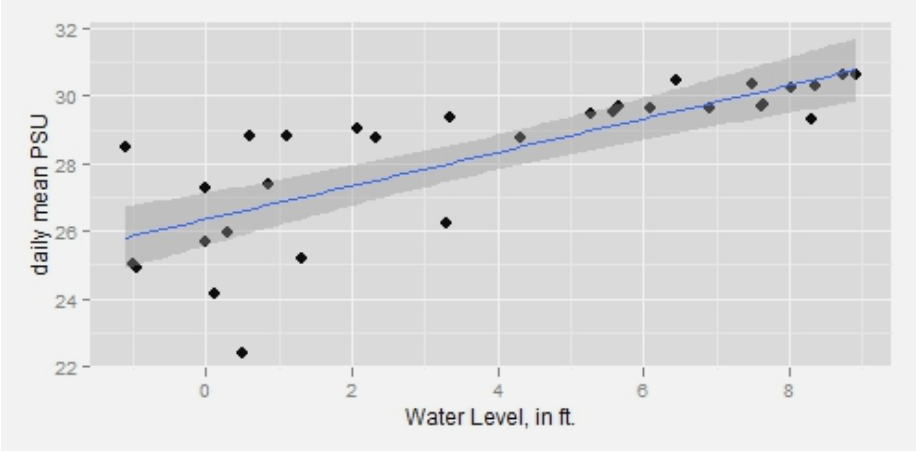


B) Mean wind direction and speed $(\mathrm{m} / \mathrm{s})$ are shown for the days sampled, showing the majority of the winds blowing from the southwest.

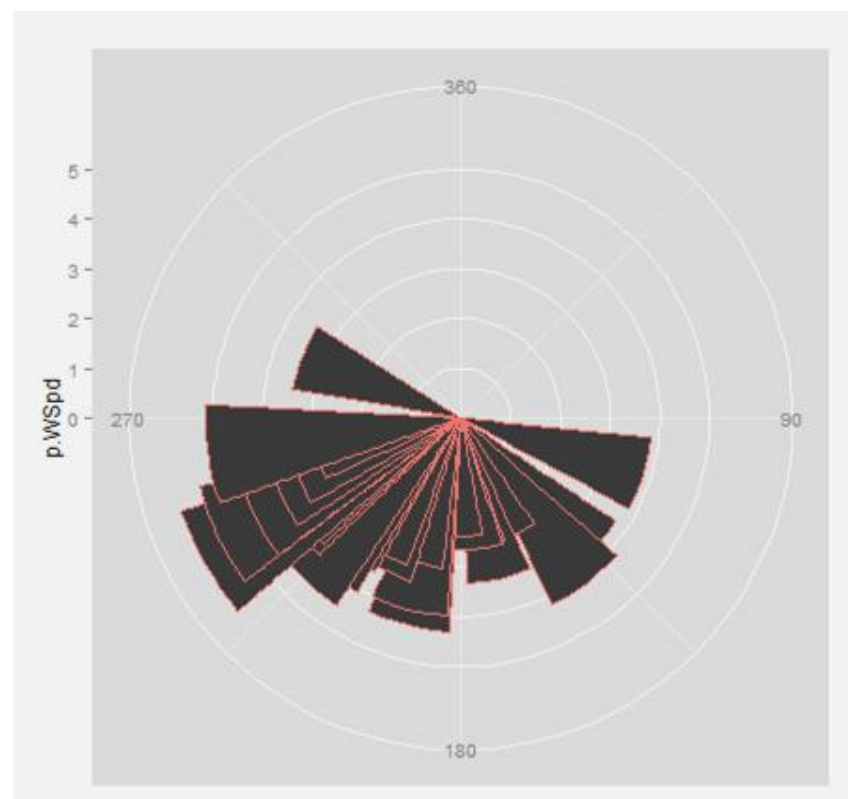

C) Water temperature increased over the sampling season

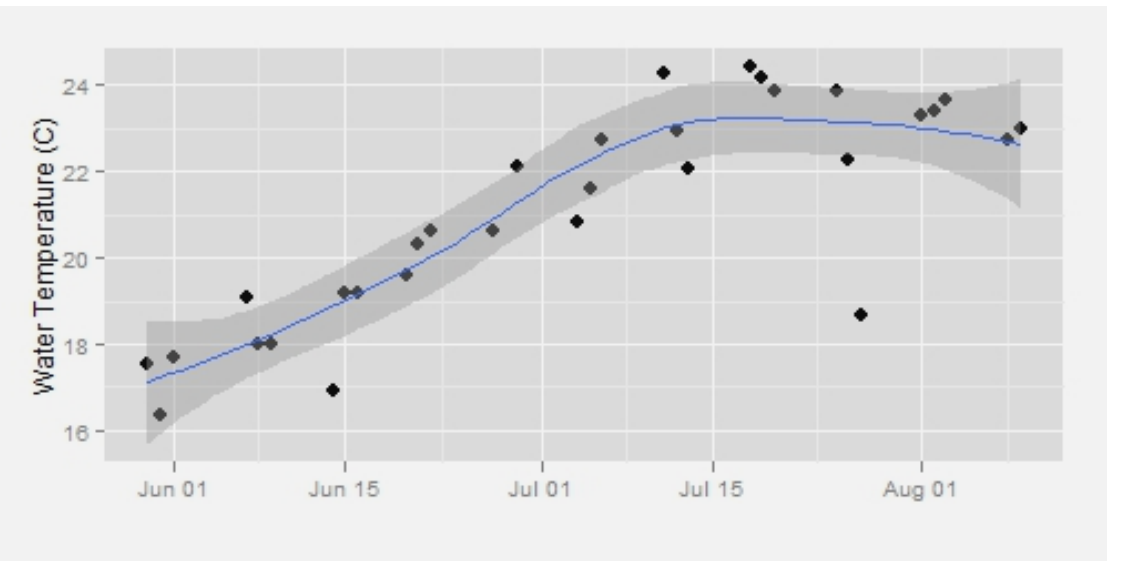




\subsection{Multiple Linear Regression models}

3.4.1 2010 Water Quality MLR: The environmental variables water temperature, tidal level, and $24 \mathrm{~h}$ average windspeed were selected for best-fit Multiple Linear Regression.

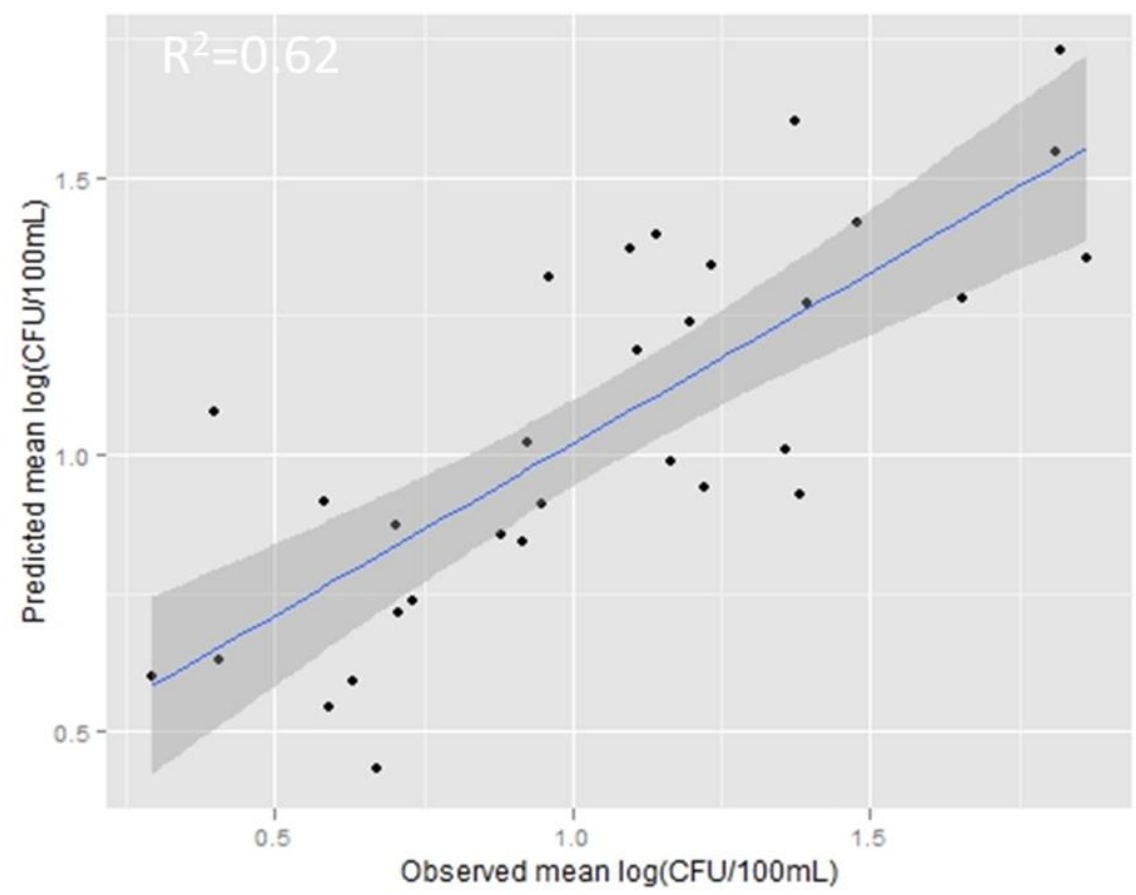

3.4.2 2010 Dry Sand MLR The environmental variables tidal range and 24h average solar insolation were selected for the best-fit Multiple Linear Regression. The model used 27 days of data, since solar insolation wasn't collected until the second week of June and there was no alternative local source for this data. 


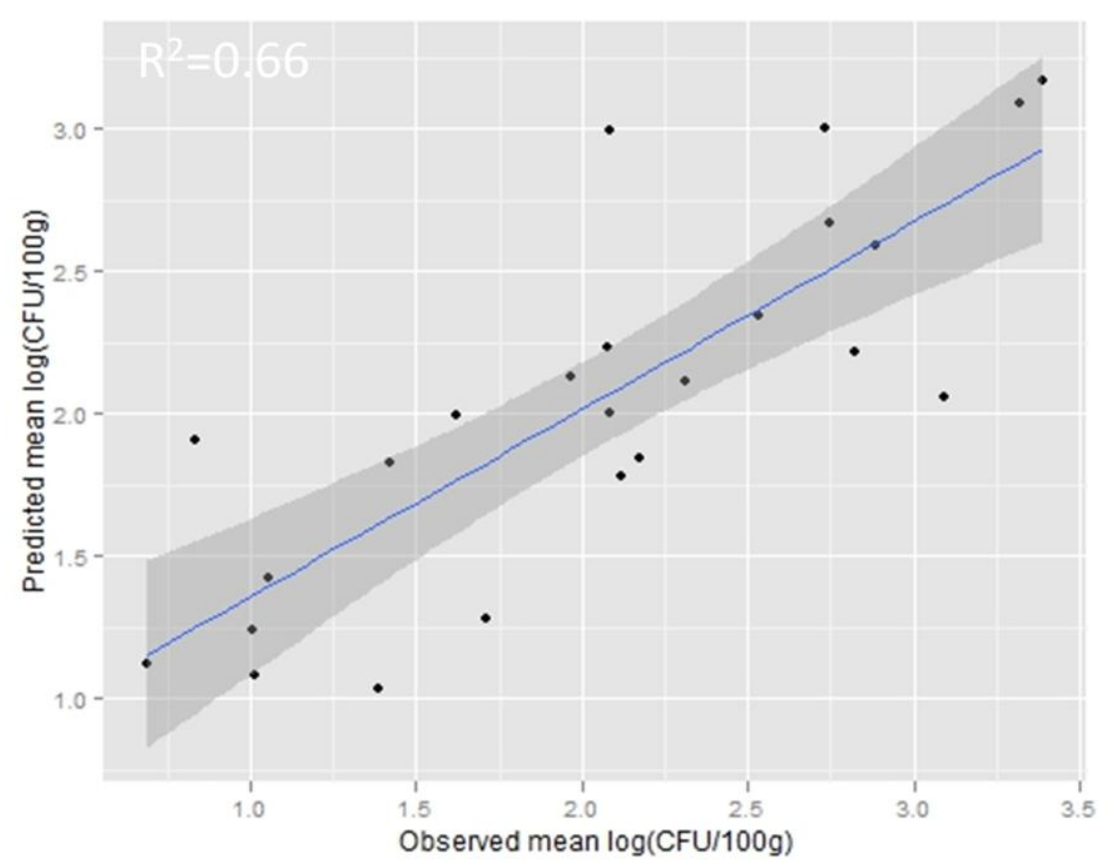

3.5 Total data from June-August 2010 suggests that ENT becomes less abundant as high-tide sands dry out

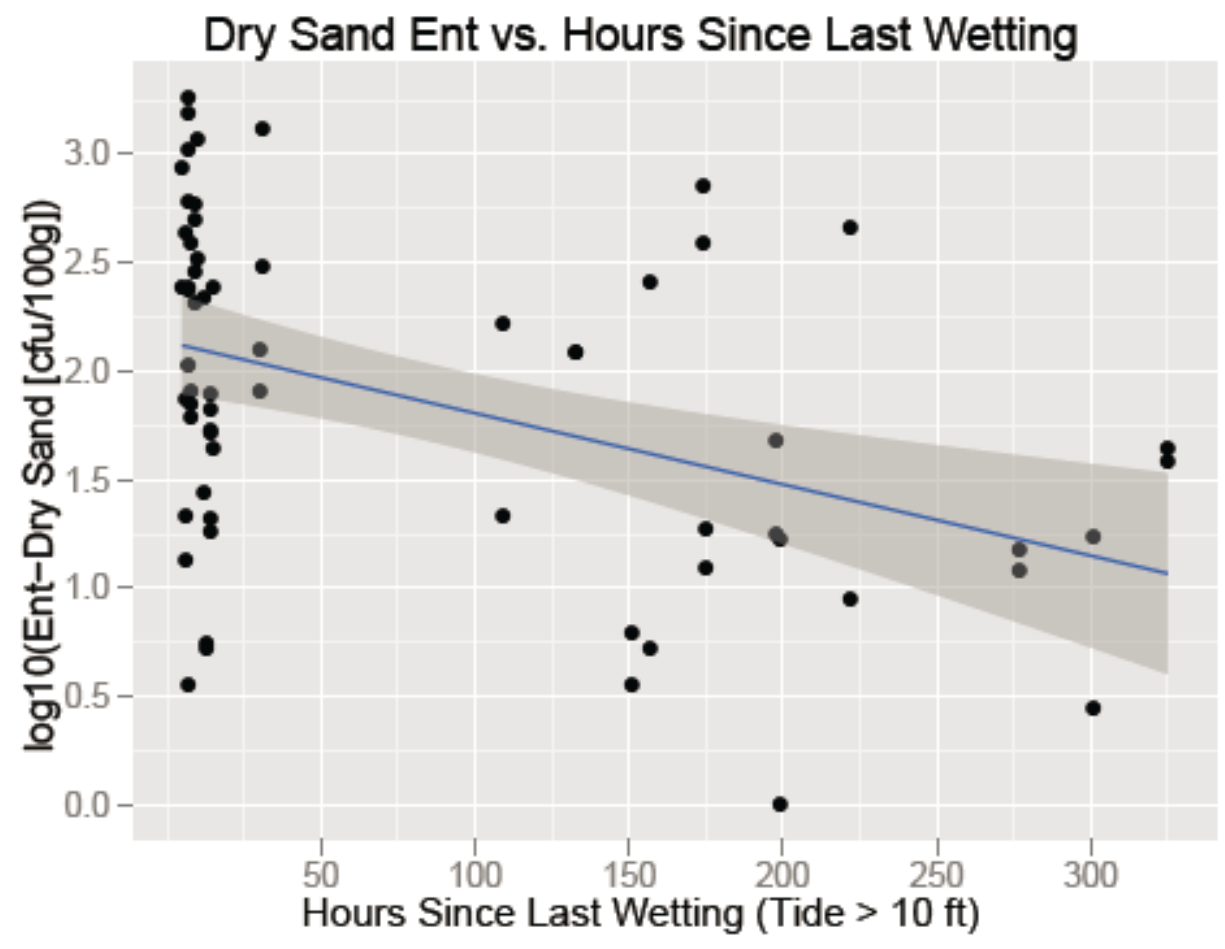




\section{References:}

1. Abdelzaher, A. M., M. E. Wright, C. Ortega, H. M. Solo-Gabriele, G. Miller, S. Elmir, X. Newman, P. Shih, J. A. Bonilla, and T. D. Bonilla. 2010. Presence of pathogens and indicator microbes at a non-point source subtropical recreational marine beach. Appl Environ Microbiol 76:724.

2. Anderson, K. L., J. E. Whitlock, and V. J. Harwood. 2005. Persistence and differential survival of fecal indicator bacteria in subtropical waters and sediments. Appl Environ Microbiol 71:30413048.

3. Boehm, A. B., and S. B. Weisberg. 2005. Tidal forcing of enterococci at marine recreational beaches at fortnightly and semidiurnal frequencies. Environmental science \& technology 39:5575-5583.

4. Boehm, A. B., K. M. Yamahara, D. C. Love, B. M. Peterson, K. McNeill, and K. L. Nelson. 2009. Covariation and photoinactivation of traditional and novel indicator organisms and human viruses at a sewage-impacted marine beach. Environmental science \& technology 43:8046-8052.

5. Bonilla, T. D., K. Nowosielski, M. Cuvelier, A. Hartz, M. Green, N. Esiobu, D. S. McCorquodale, J. M. Fleisher, and A. Rogerson. 2007. Prevalence and distribution of fecal indicator organisms in South Florida beach sand and preliminary assessment of health effects associated with beach sand exposure. Mar Pollut Bull 54:1472-1482.

6. Characklis, G. W., R. T. Noble, and J. S. Fries. 2006. Attachment of Fecal Indicator Bacteria to Particles in the Neuse River Estuary, NC. Journal of Environmental Engineering:1338-1345.

7. Converse, R. R., J. F. Griffith, R. T. Noble, R. A. Haugland, K. C. Schiff, and S. B. Weisberg. 2012. Correlation between Quantitative PCR and Culture-Based Methods for Measuring Enterococcus spp. over Various Temporal Scales at Three California Marine Beaches. Appl Environ Microbiol 78:1237-1242.

8. de Sieyes, N. R., K. M. Yamahara, B. A. Layton, E. H. Joyce, and A. B. Boehm. 2008. Submarine discharge of nutrient-enriched fresh groundwater at Stinson Beach, California is enhanced during neap tides. Limnology and Oceanography:1434-1445.

9. Dorfman, M., and K. S. Rosselot. 2011. Testing the Waters: A Guide to Water Quality at Vacation Beaches. National Resource Defense Council.

10. Feng, F., D. Goto, and T. Yan. 2010. Effects of autochthonous microbial community on the dieoff of fecal indicators in tropical beach sand. FEMS Microbiol Ecol 74:214-225.

11. Fujioka, R. S., H. H. Hashimoto, E. B. Siwak, and R. Young. 1981. Effect of sunlight on survival of indicator bacteria in seawater. Appl Environ Microbiol 41:690.

12. Gast, R. J., M. R. Dennett, and D. A. Caron. 2004. Characterization of protistan assemblages in the Ross Sea, Antarctica, by denaturing gradient gel electrophoresis. Appl Environ Microbiol 70:2028.

13. Halliday, E., and R. J. Gast. 2011. Bacteria in Beach Sands: An Emerging Challenge in Protecting Coastal Water Quality and Bather Health. Environmental science \& technology.

14. Halliday, E., J. F. Griffith, and R. J. Gast. 2010. Use of an exogenous plasmid standard and quantitative PCR to monitor spatial and temporal distribution of Enterococcus spp. in beach sands. Limnol. Oceanogr. Methods 8:146-154.

15. Hartz, A., M. Cuvelier, K. Nowosielski, T. D. Bonilla, M. Green, N. Esiobu, D. S. McCorquodale, and A. Rogerson. 2008. Survival potential of Escherichia coli and Enterococci in subtropical beach sand: implications for water quality managers. J Environ Qual 37:898-905. 
16. Heaney, C. D., E. Sams, S. Wing, S. Marshall, K. Brenner, A. P. Dufour, and T. J. Wade. 2009. Contact with beach sand among beachgoers and risk of illness. American journal of epidemiology 170:164.

17. Kay, D., C. M. Stapleton, M. D. Wyer, A. T. McDonald, J. Crowther, N. Paul, K. Jones, C. Francis, J. Watkins, J. Wilkinson, N. Humphrey, B. Lin, L. Yang, R. A. Falconer, and S. Gardner. 2005. Decay of intestinal enterococci concentrations in high-energy estuarine and coastal waters: towards real-time T90 values for modelling faecal indicators in recreational waters. Water Res 39:655-667.

18. Lee, C. M., T. Y. Lin, C. C. Lin, G. N. A. Kohbodi, A. Bhatt, R. Lee, and J. A. Jay. 2006. Persistence of fecal indicator bacteria in Santa Monica Bay beach sediments. Water Res 40:2593-2602.

19. Ludwig, W., and K. H. Schleifer. 2000. How quantitative is quantitative PCR with respect to cell counts? Systematic and applied microbiology 23:556.

20. Mallin, M. A., V. L. Johnson, and S. H. Ensign. 2009. Comparative impacts of stormwater runoff on water quality of an urban, a suburban, and a rural stream. Environmental monitoring and assessment 159:475-491.

21. Masterson, J. P., J. W. Portnoy, and G. Survey. 2005. Potential changes in ground-water flow and their effects on the ecology and water resources of the Cape Cod National Seashore, Massachusetts. US Department of the Interior, US Geological Survey.

22. McFeters, G. A., and D. G. Stuart. 1972. Survival of coliform bacteria in natural waters: field and laboratory studies with membrane-filter chambers. Appl Environ Microbiol 24:805.

23. Mika, K. B., G. Imamura, C. Chang, V. Conway, G. Fernandez, J. F. Griffith, R. A. Kampalath, C. M. Lee, C. C. Lin, and R. Moreno. 2009. Pilot-and bench-scale testing of faecal indicator bacteria survival in marine beach sand near point sources. J Appl Microbiol 107:72-84.

24. Noble, R. T., I. M. Lee, and K. C. Schiff. 2004. Inactivation of indicator micro-organisms from various sources of faecal contamination in seawater and freshwater. J Appl Microbiol 96:464472.

25. Olyphant, G. A., and R. L. Whitman. 2004. Elements of a predictive model for determining beach closures on a real time basis: The case of 63rd Street Beach Chicago. Environmental monitoring and assessment 98:175-190.

26. Ortega, C., H. M. Solo-Gabriele, A. Abdelzaher, M. Wright, Y. Deng, and L. M. Stark. 2009. Correlations between microbial indicators, pathogens, and environmental factors in a subtropical Estuary. Mar Pollut Bull 58:1374-1381.

27. Oshiro, R., and R. Fujioka. 1995. Sand, soil, and pigeon droppings: sources of indicator bacteria in the waters of Hanauma Bay, Oahu, Hawaii. Water science and technology 31:251-254.

28. Piggot, A. M., J. S. Klaus, S. Johnson, M. Phillips, and H. M. Solo-Gabriele. 2012. Enterococci Levels are Related to Sediment Biofilms at Recreational Beaches in South Florida. Appl Environ Microbiol.

29. Robinson, C., B. Gibbes, and L. Li. 2006. Driving mechanisms for groundwater flow and salt transport in a subterranean estuary. Geophys. Res. Lett 33:L03402.

30. Robinson, C., L. Li, and D. Barry. 2007. Effect of tidal forcing on a subterranean estuary. Advances in Water Resources 30:851-865.

31. Santoro, A. E., and A. B. Boehm. 2007. Frequent occurrence of the human-specific Bacteroides fecal marker at an open coast marine beach: relationship to waves, tides and traditional indicators. Environ Microbiol 9:2038-2049.

32. Sercu, B., L. C. V. D. Werfhorst, J. Murray, and P. A. Holden. 2008. Storm drains are sources of human fecal pollution during dry weather in three urban southern California watersheds.

Environmental science \& technology 43:293-298. 
33. Sinton, L. W., R. J. Davies-Colley, and R. G. Bell. 1994. Inactivation of enterococci and fecal coliforms from sewage and meatworks effluents in seawater chambers. Appl Environ Microbiol 60:2040-2048.

34. Sinton, L. W., C. H. Hall, P. A. Lynch, and R. J. Davies-Colley. 2002. Sunlight inactivation of fecal indicator bacteria and bacteriophages from waste stabilization pond effluent in fresh and saline waters. Appl Environ Microbiol 68:1122.

35. Suter, E., A. R. Juhl, and G. D. O'Mullan. 2011. Particle Association of Enterococcus and Total Bacteria in the Lower Hudson River Estuary, USA. Journal of Water Resource and Protection 3:715-725.

36. U.S.E.P.A. 2002. Method 1600: membrane filter test method for enterococci in water.

37. U.S.E.P.A. 2011. Recreational Water Quality Criteria. In O. o. Water (ed.), Washington, D.C.

38. Walters, S. P., K. M. Yamahara, and A. B. Boehm. 2009. Persistence of nucleic acid markers of health-relevant organisms in seawater microcosms: implications for their use in assessing risk in recreational waters. Water Res 43:4929-4939.

39. Wheeler Alm, E., J. Burke, and A. Spain. 2003. Fecal indicator bacteria are abundant in wet sand at freshwater beaches. Water Res 37:3978-3982.

40. Whitman, R. L., and M. B. Nevers. 2003. Foreshore sand as a source of Escherichia coli in nearshore water of a Lake Michigan beach. Appl Environ Microbiol 69:5555.

41. Wright, M., A. Abdelzaher, H. Solo-Gabriele, S. Elmir, and L. Fleming. 2011. The inter-tidal zone is the pathway of input of enterococci to a subtropical recreational marine beach. Water science and technology 63:542-549.

42. Wright, M. E., H. M. Solo-Gabriele, S. Elmir, and L. E. Fleming. 2009. Microbial load from animal feces at a recreational beach. Mar Pollut Bull 58:1649-1656.

43. Yamahara, K. M., B. A. Layton, A. E. Santoro, and A. B. Boehm. 2007. Beach sands along the California coast are diffuse sources of fecal bacteria to coastal waters. Environmental science \& technology 41:4515-4521.

44. Yamahara, K. M., S. P. Walters, and A. B. Boehm. 2009. Growth of enterococci in unaltered, unseeded beach sands subjected to tidal wetting. Appl Environ Microbiol 75:1517. 


\section{CHAPTER 6: Pyrosequencing analysis of bacterial communities in sands and water at anthropogenically impacted beaches}

\section{Introduction}

Fecal indicator bacteria are increasingly well-documented in sands at a range of freshwater and marine beaches of varied climates $(3,6,19,48,49)$, bringing into question whether their ability to persist in the surfzone environment compromises their utility as proxies for the risk of contact with pathogens in recreational waters. Contaminated sands may impact beachgoers either by negatively contributing to bathing water quality through cycles of deposition and resupsension of bacteria between sand and water $(16,53)$, or perhaps be more directly harmful through physical contact with sands or ingestion of sands. Epidemiological studies that examined the health outcomes associated with beach sand activities revealed that increased interaction with sands (e.g. digging in, being buried in) corresponds to increased outcomes of illness (23), most commonly gastrointestinal illness but also including skin, eye, ear and respiratory infections. Interaction with sands that have a higher amount of fecal pollution (as measured by both molecular and culture-based quantification of the marine fecal indicator Enterococcus) also corresponded to increased outcomes of illness among beachgoers (22).

To date, a variety of viral, bacterial and eukaryotic human pathogens have been recovered from environmental beach sands $(1,12,50)$, but it is difficult to predict which specific pathogens may be present at a beach at any given time due to variations in sources of human and animal fecal pollution, as well as whether the fecal pathogens detected in sands are abundant enough to present a significant risk of illness (41). Microcosm studies suggest pathogens in sands persist or decay at rates that can significantly differ from rates observed in the microcosm's fecal indicator 
bacteria, but that both pathogens and indicators can be mobilized from sewage-contaminated sands when inundated with seawater (50). In the environment, it is likely that fecal indicators and pathogens respond differently to the complex interactions between environmental variables such as moisture, temperature and sunlight $(1,21,36,50,51)$ as well as to the ecological pressures presented by the indigenous microbial community $(7,13)$. While intertidal beach sands are frequently in contact with the overlying water, previous studies have indicated that biofilm formation on sand grains effectively maintains separation between bacterial communities in sands, porewater, and overlying water (17) and that sands and sediments have distinctly different communities than those found in overlying water (33).

Interaction with beach sands may be an overlooked mode of disease transmission to some populations of beachgoers. Currently, we lack a basic understanding about how the complex environmental bacterial communities in sands, which may include fecal indicators and pathogens, are related to the putative pollution events that are detected through routine culturebased water quality monitoring. We especially lack information about whether episodic water quality violations are related to the bacteriological quality of surfzone sands, and whether signatures of human contamination can be identified in any or all of the sample types during or resulting from water quality violation events.

The goal of this study was to leverage pyrosequencing datasets of $16 \mathrm{~S}$ hypervariable region ribosomal DNA to survey total and constituent components of the bacterial communities at two beaches. Samples of dry sand, intertidal sand, and the overlying waters were collected during two-week periods at locations on the west and east coast of the United States, on days when water quality violations occurred as well as on days representative of baseline fecal indicator bacteria concentrations. At one site (Avalon, CA) waters frequently violate water quality 
standards and have been identified as being impacted by decaying sewage infrastructure; at the second site (Provincetown, MA) water quality violations are infrequent and of unknown origin, but have a history of occurring during both wet and dry weather.

Short sequence tags were used to examine the total bacterial community composition, the presence of sequence tags belonging to the marine fecal indicator Enterococcus, the presence of a broader group of alternative fecal indicators derived from studies of human sewage (35), and the presence of sequence tags related to known human pathogens (4). Pyrosequencing was particularly advantageous for this combination of broad and specific queries, since the depth of sampling enables detection of many low-abundance members of the community and can document shifts in the community structure over time $(10,17)$. Although molecular methods (e.g., ARISA, T-RFLP, clone libraries and 454 sequencing) have been used to document bacterial diversity and community structure in similar environments such as submerged marine sediments $(25,32)$, lake sediments $(43)$, and shallow subtidal sands $(5,17,18)$, these previous studies focused on the impact of physical, chemical or biological disturbance events on bacterial community structure. The results presented here are unique in the utilization of rare sequence tags to examine the impact of suspected anthropogenic input in both water and sand.

\section{Materials and Methods}

\subsection{Field Sites and Sample Collection}

Water, wet sand (covered in approximately $10 \mathrm{~cm}$ of water) and dry sand at the high tide line were sampled at Avalon Bay Beach (Catalina Island, CA, Figure 1) from the end of July through the beginning of September, 2007. The site locations and qPCR methods used for enumerating enterococci in sands are described in detail elsewhere (20). Briefly, sand cores were collected in 
triplicate by hand in $50 \mathrm{~mL}$ sterile Falcon tubes from three sites spanning a $200 \mathrm{~m}$ along-shore transect. Water from the sites was filtered onto Durapore filters and $100 \mathrm{~mL}$ was also filtered to enumerate culturable enterococci using the EPA 1600 method (44). All samples for DNA analysis were frozen and shipped to Woods Hole, MA, where they were kept at $-80^{\circ} \mathrm{C}$ prior to genomic DNA extraction. Enterococcus spp. were quantified via qPCR using primers targeting the $23 \mathrm{~S} \mathrm{rDNA}(34)$. Wet and dry sand from three days, each a week apart, were chosen for pyrosequencing analysis based on differences in water quality as per official beach closures, and also based on the relative amount of enterococci DNA present in the sands. On August $11^{\text {th }}$ and August $18^{\text {th }}$ the water complied with bacterial health standards, but sands differed in the amount of enterococci as detected by qPCR with August $11^{\text {th }}$ having relatively elevated enterococci and August $18^{\text {th }}$ having a low level of enterococci (20). The third time point, August $25^{\text {th }}$, corresponded to a violation of the bacterial water quality standard and elevated enterococci in sands. These samples were designated as Avalon (AV) water, wet sand or dry sand (H/W/D) sand from day 1, 2, or 3 (detailed in Table 1).

Figure 1: Sites sampled at Provincetown Harbor, MA (left) and at Avalon Bay, CA (right)
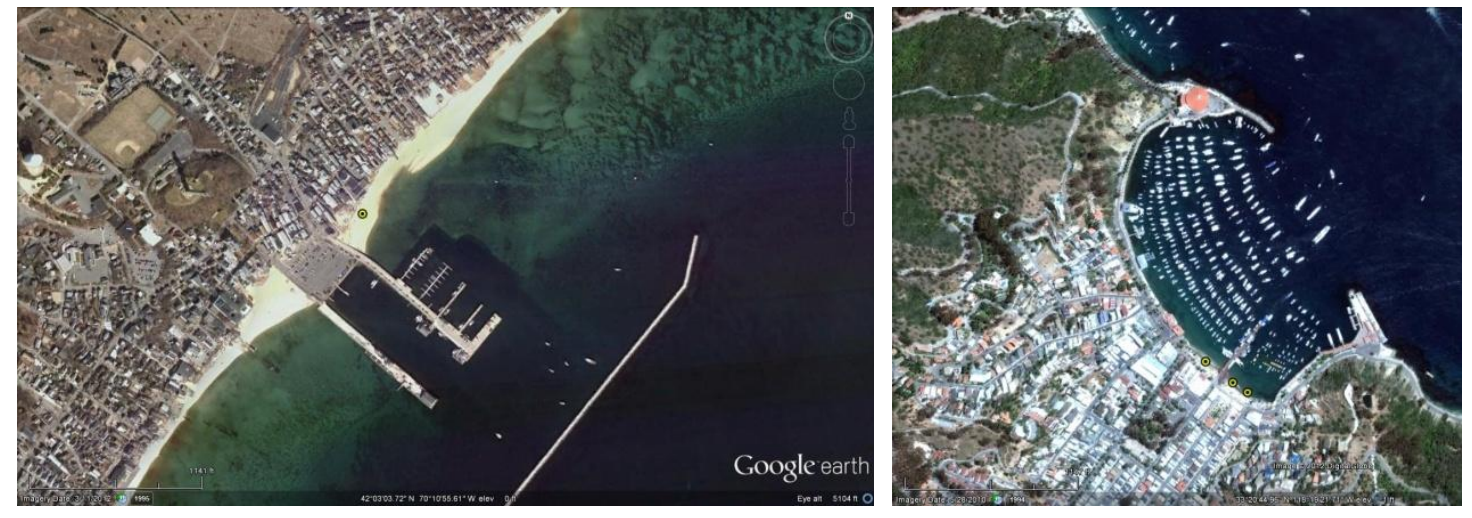


\begin{tabular}{|c|c|c|c|c|c|c|}
\hline \multicolumn{7}{|c|}{ Table 1: Beach sand samples sequenced in this study } \\
\hline Archived Sample ID (VAMPS): & Abb. in paper: & Date: & Sample & Location & $\begin{array}{l}>104 \\
\text { CFU? }\end{array}$ & $\begin{array}{l}\text { Culturable ENT } \\
\text { density }\end{array}$ \\
\hline RJG_PTW_Bv6v4_AVB_0001_2007_08_11 & AV H1 & 08-11-2007 & Water & Avalon & No* & $\begin{array}{l}55+/-123 \\
\text { CFU/100mL }\end{array}$ \\
\hline RJG_PTW_Bv6v4_AVB_0002_2007_08_18 & AV H2 & 08-18-2007 & Water & Avalon & No* & $\begin{array}{l}156+/-176 \\
\text { CFU/100mL }\end{array}$ \\
\hline RJG_PTW_Bv6v4_AVB_0003_2007_08_25 & AV H3 & 08-25-2007 & Water & Avalon & Yes & $\begin{array}{l}147+/-42 \\
\text { CFU/100mL }\end{array}$ \\
\hline RJG_BSC_Bv6_AV081107W & AV W1 & 08-11-2007 & $\begin{array}{l}\text { Wet } \\
\text { Sand }\end{array}$ & Avalon & No & $\begin{array}{l}\text { 256+/- 1056 } \\
\text { MPN/100g sand }\end{array}$ \\
\hline RJG_BSC_Bv6_AV081807W & AV W2 & 08-18-2007 & $\begin{array}{l}\text { Wet } \\
\text { Sand }\end{array}$ & Avalon & No & $\begin{array}{l}\text { 124+/- } 317 \\
\text { MPN/100g sand }\end{array}$ \\
\hline RJG_BSC_Bv6_AV082507W & AV W3 & $08-25-2007$ & $\begin{array}{l}\text { Wet } \\
\text { Sand }\end{array}$ & Avalon & Yes & $\begin{array}{l}83+/-63 \\
\text { MPN/100g sand }{ }^{2}\end{array}$ \\
\hline RJG_BSC_Bv6_AV081107D & AV D1 & 08-11-2007 & $\begin{array}{l}\text { Dry } \\
\text { Sand }\end{array}$ & Avalon & No & N/A \\
\hline RJG_BSC_Bv6_AV081807D & AV D2 & 08-18-2007 & $\begin{array}{l}\text { Dry } \\
\text { Sand }\end{array}$ & Avalon & No & N/A \\
\hline RJG_BSC_Bv6_AV082507D & AV D3 & $08-25-2007$ & $\begin{array}{l}\text { Dry } \\
\text { Sand }\end{array}$ & Avalon & Yes & N/A \\
\hline RJG_PTW_Bv6v4_PTW_0001_2009_06_29 & PTW H1 & 06-29-2009 & Water & Provincetown & Yes & $140 \mathrm{CFU} / 100 \mathrm{~mL}^{3}$ \\
\hline RJG_PTW_Bv6v4_PTW_0002_2009_06_30 & PTW H2 & 06-30-2009 & Water & Provincetown & No & $35 \mathrm{CFU} / 100 \mathrm{~mL}^{3}$ \\
\hline RJG_PTW_Bv6v4_PTW_0003_2009_07_07 & PTW H3 & 07-05-2009 & Water & Provincetown & No & $30 \mathrm{CFU} / 100 \mathrm{~mL}^{3}$ \\
\hline RJG_PTW_Bv6v4_PTW_0004_2009_07_12 & PTW H4 & 07-12-2009 & Water & Provincetown & Yes & $185 \mathrm{CFU} / 100 \mathrm{~mL}^{3}$ \\
\hline RJG_PTW_Bv6v4_PTW_0005_2009_07_13 & PTW H5 & 07-13-2009 & Water & Provincetown & No & $90 \mathrm{CFU} / 100 \mathrm{~mL}^{3}$ \\
\hline RJG_PTW_Bv6v4_PTW_0006_2009_06_29 & PTW W1 & 06-29-2009 & $\begin{array}{l}\text { Wet } \\
\text { Sand }\end{array}$ & Provincetown & Yes & $\begin{array}{l}169 \mathrm{CFU} / 100 \mathrm{~g} \text { dry } \\
\text { weight sand }\end{array}$ \\
\hline RJG_PTW_Bv6v4_PTW_0007_2009_06_30 & PTW W2 & 06-30-2009 & $\begin{array}{l}\text { Wet } \\
\text { Sand }\end{array}$ & Provincetown & No & $\begin{array}{l}95 \mathrm{CFU} / 100 \mathrm{~g} \text { dry } \\
\text { weight sand }^{3}\end{array}$ \\
\hline RJG_PTW_Bv6v4_PTW_0008_2009_07_07 & PTW W3 & 07-05-2009 & $\begin{array}{l}\text { Wet } \\
\text { Sand }\end{array}$ & Provincetown & No & $\begin{array}{l}715 \text { CFU/100g } \\
\text { sand }^{3}\end{array}$ \\
\hline RJG_PTW_Bv6v4_PTW_0009_2009_07_12 & PTW W4 & 07-12-2009 & $\begin{array}{l}\text { Wet } \\
\text { Sand }\end{array}$ & Provincetown & Yes & $\begin{array}{l}858 \text { CFU/100g } \\
\text { sand }^{3}\end{array}$ \\
\hline RJG_PTW_Bv6v4_PTW_0010_2009_07_13 & PTW W5 & 07-13-2009 & $\begin{array}{l}\text { Wet } \\
\text { Sand }\end{array}$ & Provincetown & No & $\begin{array}{l}217 \mathrm{CFU} / 100 \mathrm{~g} \\
\text { sand }^{3}\end{array}$ \\
\hline RJG_PTW_Bv6v4_PTW_0011_2009_06_29 & PTW D1 & 06-29-2009 & $\begin{array}{l}\text { Dry } \\
\text { Sand }\end{array}$ & Provincetown & Yes & $\begin{array}{l}2927 \text { CFU/100g } \\
\text { sand }^{3}\end{array}$ \\
\hline RJG_PTW_Bv6v4_PTW_0012_2009_06_30 & PTW D2 & 06-30-2009 & $\begin{array}{l}\text { Dry } \\
\text { Sand }\end{array}$ & Provincetown & No & $\begin{array}{l}2419 \text { CFU/100g } \\
\text { sand }^{3}\end{array}$ \\
\hline RJG_PTW_Bv6v4_PTW_0013_2009_07_07 & PTW D3 & 07-05-2009 & $\begin{array}{l}\text { Dry } \\
\text { Sand }\end{array}$ & Provincetown & No & $\begin{array}{l}329 \mathrm{CFU} / 100 \mathrm{~g} \\
\text { sand }^{3}\end{array}$ \\
\hline RJG_PTW_Bv6v4_PTW_0014_2009_07_12 & PTW D4 & 07-12-2009 & $\begin{array}{l}\text { Dry } \\
\text { Sand }\end{array}$ & Provincetown & Yes & $\begin{array}{l}10745 \text { CFU/100g } \\
\text { sand }^{3}\end{array}$ \\
\hline RJG_PTW_Bv6v4_PTW_0015_2009_07_13 & PTW D5 & 07-13-2009 & $\begin{array}{l}\text { Dry } \\
\text { Sand }\end{array}$ & Provincetown & No & $\begin{array}{l}342 \text { CFU/100g } \\
\text { sand }^{3}\end{array}$ \\
\hline
\end{tabular}

${ }^{1}$ Geometric mean +/- standard deviation of samples collected by SCCWRP at three sites along the beach (Figure 1) at 8am using EPA 1600.

*Based on posted results from health department, not based on these bacterial counts. On the $25^{\text {th }}$, all water quality samples were $>104$

$\mathrm{CFU} / 100 \mathrm{~mL}$, whereas the other days were more variable as illustrated in the standard deviation.

${ }^{2}$ MPN/100g dry weight sand, grab samples collected at a single site (A) at the beach (MPN calculated by Jenny Jay)

${ }^{3}$ Collected in the course of this study, using EPA 1600 for water and modified for sands, CFU in wet and dry sand normalized to dry weight 
In the summer of 2009, the beach at 333 Commercial St. (Provincetown, MA, Figure 1) was sampled three days per week from mid June through the end of July. Samples from five days that represented a range of water quality and wet weather conditions were chosen for pyrosequencing analysis. These samples were designated as Provincetown (PTW) water, wet sand or dry sand (H/W/D) from days numbered 1-5 (detailed in Table 1). Ancillary environmental data were collected at each sampling event, including the temperature of the sample (water temperature, wet sand temperature, dry sand temperature), the tidal range prior to the sampling event (reflecting variations in spring and neap cycles), the level of the tide during the sampling event, the amount of precipitation within the previous $24 \mathrm{~h}$, and the amount of enterococci cultured from the sample.

\subsection{Genomic DNA extraction and 454 pyrosequencing}

The UltraClean Mega Prep soil DNA kit (MoBio Laboratories, Inc., Solana Beach, CA) was used to extract genomic DNA from $9.0 \mathrm{~g}$ of a wet-weight sand composite of three replicates taken from the sand surface at the beach. DNA was extracted from filtered water samples using a modified combination of hot detergent lysis buffer and mechanical disruption as previously described (15). Eluted DNA was checked for purity with a NanoDrop spectrophotometer before PCR was used to amplify the V6 hypervariable region. Avalon sand samples were sequenced first, on a Roche Genome Sequencer GS-FLX using standard protocols (26), which at the time were limited toV6 amplicon libraries of tag sequences 60bp long. By 2009 and the second sequencing run, the sequence tag read length had improved to 250bp, so combined V4 and V6 amplicon libraries were sequenced. In all samples, sequences of adapters and primers were trimmed and low-quality reads removed as described previously (27). Taxonomy was assigned through the Global Alignment for Sequence Taxonomy (GAST) using a 16S hypervariable 
region reference database (27). GAST assigns taxonomy to a tag based on a two-thirds majority vote of the taxonomy of the nearest full-length relatives using a threshold of $>80 \%$ sequence similarity, and taxonomical assignments within samples are archived and available for comparison on the Visualization and Analysis of Microbial Population Structures (VAMPS) project website (http://www.vamps.mbl.edu).

\subsection{Data Analysis}

Sequence tag data was normalized to relative abundance within the sample for analysis and visualization. The multivariate statistical software package PRIMER-E (9) was used to analyze the relative abundance data of sequence tags successfully assigned to taxa within our samples, with the one-way ANOSIM testing significance of difference between groups of samples based on differences in site, sample type and water quality violation events. Multidimensional scaling analysis was used to generate graphical representations with Non-metric Multi-dimensional Scaling (NMDS) plots of relative differences in community composition between samples from Avalon and Provincetown. The BIOENV rank-correlation procedure was used with the Provincetown samples to determine which combinations of variables best explain patterns in the sequence tag abundance data. The SIMPER routine was used to identify the specific sequence tags with the greatest contribution to the dissimilarity observed between samples.To assess if fecal organisms present in beach sand were associated with sewage, sequence tags belonging to three orders (Bifidobacteriales, Bacteroidales and Clostridiales) were extracted from the total datasets for comparison between samples. These were directly compared to sewage datasets (35) in the VAMPS program. To assess the pathogen-related sequence tags present in different sample types, a list of traditional and emerging bacterial agents of waterborne disease and bacterial pathogens associated with sewage sludge and animal manures was compiled from the 
microbial contaminants section of the USEPA Contaminant Candidate List 3 (CCL-3) and (4). Sequence tags within the beach sand and water datasets were identified as pathogen-related if they had been taxonomically classified as a species on the list, or if the tag was unresolved at the species level but assigned to a genus that contained pathogens on the list.

\section{Results}

\subsection{Gross community structure}

Thirty-nine bacterial phyla were represented among the sequence tags from sand and water samples in this study. The average distribution of sequence tags among dominant phyla in each sample type is presented in Figure 2.

Figure 2: Relative abundance of phyla containing $>1 \%$ of total sequence tags

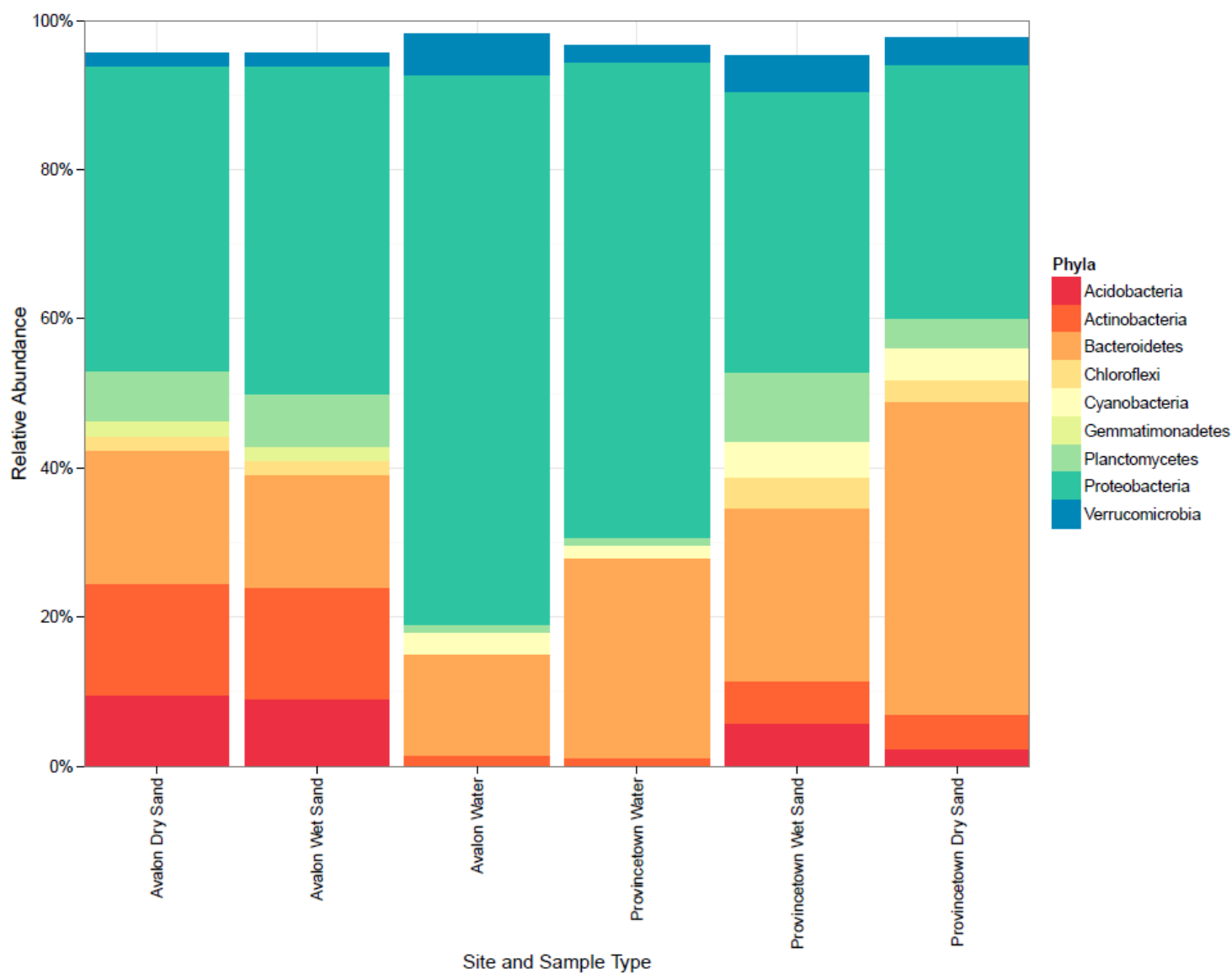


Proteobacteria dominate the sequence tags from water samples regardless of site; within this phylum, the orders Alphaproteobacteria and Gammaproteobacteria contain the majority of sequence tags, which are present in a ratio of approximately $2: 1$ respectively. Other dominant phyla found in surf zone waters included the Bacteroidetes, Cyanobacteria, and Verrucomicrobia, which together with the Proteobacteria contain approximately 95\% of the bacterial sequence tags from waters at Avalon and Provincetown.

In the Avalon beach sands, five phyla collectively contain $>90 \%$ of the 628,735 tags identified to phyla (Figure 2); these are the Proteobacteria, Bacteroidetes, Actinobacteria, Planctomycetes and Acidobacteria. Three other phyla, the Chloroflexi, Gemmatimonadetes and Verrucomicrobia, were present at appreciable relative abundance (>1\% of total phyla tags). Within the Proteobacteria in sands, the Alphaproteobacteria and Gammaproteobacteria were again the most abundantly represented orders, but sequence tags from the Deltaproteobacteria were also relatively abundant, containing approximately $5 \%$ of the total sequence tags from sand samples. Provincetown sands were dominated by the same phyla found at Avalon, but phyla that were minor components at Avalon (Chloroflexi, Cyanobacteria, and Verrucomicrobia) claimed a greater proportion of sequence tags in Provincetown sands, generally at the expense of the Acidobacteria and Actinobacteria.

\subsection{Community composition based on shared sequence tags}

Although the phyla dominating beach sand and water communities are broadly similar, analysis of the distribution of specific sequence tags among samples yielded a more localized view of community composition. A one-way Analysis of Similarity test (ANOSIM) rejected the null hypothesis that there was no significant difference in total community structure at the level of 
individual sequences based on the sample type (water, wet sand, dry sand) with a global R of $0.698(\mathrm{p} \leq 0.001)$. Likewise, a one-way ANOSIM rejected the null hypothesis that there were no significant differences in total community structure at the level of individual sequences between sites (Avalon vs. Provincetown) with a weak but still significant Global $\mathrm{R}$ of $0.3(\mathrm{p} \leq 0.01)$. The NMDS ordination (Figure 3) illustrates the split between water samples and sand samples (groupings differentiated with $>50 \%$ sequence tag similarity) and within that, samples are further separated by site (differentiated with $>60 \%$ sequence tag similarity). Within the Provincetown sand samples, there are further groupings that correspond to wet and dry sand. The differentiation between Provincetown wet and dry sand, a phenomena not observed among Avalon sands, likely reflects the greater tidal range at Provincetown (2-4m) and thus stronger physical separation and more distinct environmental conditions between the intertidal and upper beach sand bacterial populations. Although other temporal influences cannot be precluded, the differences between water samples at Provincetown may in part be attributed to tidal stage, as water samples collected during high $(\mathrm{H} 1$ and $\mathrm{H} 2)$ and low tides $(\mathrm{H} 3, \mathrm{H} 4, \mathrm{H} 5)$ are more similar to each other $(>70 \%)$. 
Figure 3: NMDS plot of total bacterial community composition in samples

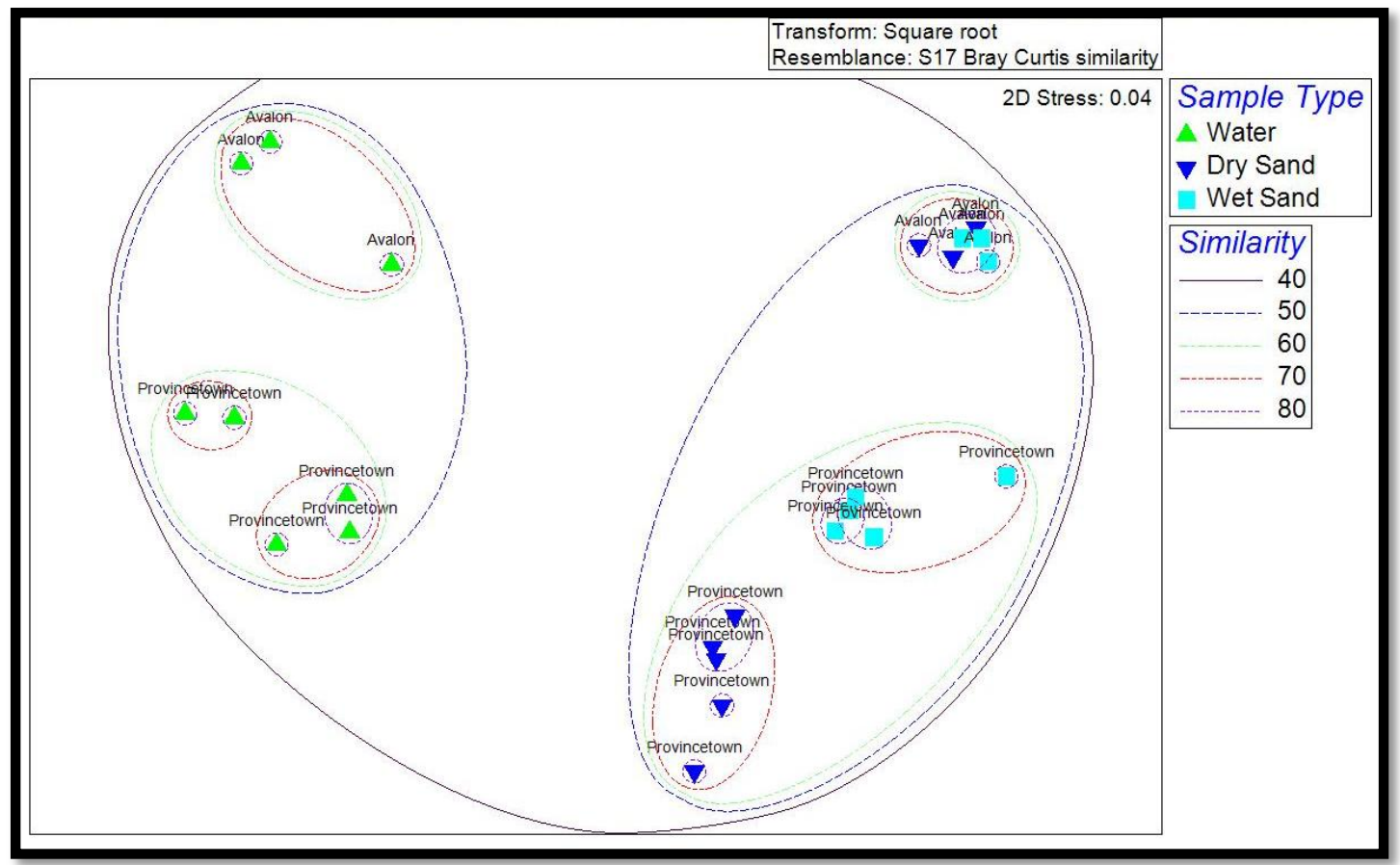

\subsection{Environmental variables influencing total community composition at Provincetown}

Environmental variables including sample temperature, tidal range, water level, precipitation and amount of enterococci were used in the BIOENV rank-correlation procedure, in which variables or combinations of variables are selected based on how they best explain patterns in the sequence tag abundance data. Among Provincetown water samples, the variables water temperature and tidal range were selected together to produce the best possible $r=0.758$. The only relationship between the environmental variables and wet sand bacterial samples was $r=0.164$, with the single selection of tidal range. Dry sand samples had a better relationship to environmental variables with $\mathrm{r}=0.467$ for dry sand temperature. Thus, temperature and tidal range emerged as the most important environmental variables shaping total community structure in water, and sand community structure was explained to a lesser extent by these variables. 


\subsection{Community composition of alternative indicator sequence tag sample subsets}

A previous study used 454 sequencing technology to examine both human waste and wastewater treatment plant influent, and identified a group of bacteria as potential alternative indicators of fecal pollution belonging to the orders Clostridiales, Bifidobacteriales and Bacteroidales (32). These taxonomic groups include both human-pathogenic and commensal organisms. In this study, sequence tags identified within these orders from the total the beach sand and water tag datasets were compared to the sewage tag datasets to determine whether there were trends in any of the sample types that corresponded to water quality violation events. Overall, although all samples contained sequence tags belonging to these orders, there was very little overlap between the specific sequence tags recovered from sewage and environmental samples. The only case of a putative tag signature shared between sewage and environmental samples (tags identified as Clostridiales; Lachnospiraceae; Roseburia; spp. N/A) was found in Provincetown waters and wet sand on the day of and following the dry weather exceedance $(1 \mathrm{H}$ and $2 \mathrm{H})$, and in waters and dry sand the day of and following the wet-weather exceedance $(4 \mathrm{H}$ and $5 \mathrm{H})$. These tagswere also present in Avalon water samples $1 \mathrm{H}$ and $3 \mathrm{H}$ (corresponding to the dry weather exceedance event). Consistent with it's hypothesized role as a sewage indicator, the Roseburia tags were two to three orders of magnitude lower in relative abundance in environmental samples than would typically be found in sewage. The one-way ANOSIM showed that there were no significant differences in the distribution of Clostridiales, Bifidobacteriales and Bacteroidales when samples were classified as having acceptable or unacceptable water quality (outlined in

Table 1). However, ANOSIM showed significant differences among these orders when samples were grouped by site $(\mathrm{R}=0.545, \mathrm{p}=0.001)$ or sample type $(\mathrm{R}=0.298, \mathrm{p}=0.001)$. The SIMPER routine revealed that the differences between Clostridiales, Bifidobacteriales and Bacteroidales 
among sample types were primarily driven by the dominance of specific sewage sequence tags from the Bacteroidales (Bacteroides, Parabacteroides, Paludibacter) and Clostridiales (Blauthia and Fecalibacterium), all of which were much more abundant in sewage than in sands or waters.

Sewage samples from the study of McLellan et al. (35) were found to be far less heterogeneous than the environmental samples collected in this study, as SIMPER revealed that the withingroup similarity of alternative indicators in the sewage community was $77 \%$, compared to $46 \%$ similarity within the water samples, and only $32 \%$ and $35 \%$ similarity for the wet sand and dry sand samples. Alternative fecal indicators differentiating Avalon samples were primarily sequence tags identified to the family Ruminococcaceae (genus unresolved), and the genus Alistipes within the Bacteroidales. Provincetown samples were differentiated by a relative abundance of tags belonging to Clostridiales (Robinsonella, Fusibacter and Acetivibrio).

\subsection{Environmental variables influence alternative fecal indicators at Provincetown}

When the BIOENV procedure was run with the same environmental variables but with the smaller subset of tags in the orders Clostridiales, Bifidobacteriales and Bacteroidales rather than the entire data set, the best correlations improved. The variable water temperature was found to best explain the patterns of abundance within the group of potentially sewage-associated orders recovered from water samples $(\mathrm{r}=0.867)$, and dry sand temperature best explained the patterns of abundance within the group of potentially sewage-associated orders recovered from dry sands $(\mathrm{r}=0.837)$, suggesting that this subset of the total community is more strongly influenced by temperature (or perhaps that bacterial loads to the beach covary with temperature) than by traditional fecal indicator abundance.

\subsection{Distribution of Pathogen-containing genera and species}


The distribution of organisms that are closely related to known human pathogens was examined to determine whether they exhibited any trends within the beach sand and water samples. Among those samples, tags were taxonomically assigned within twenty-nine genera and fourteen species known to contain human pathogens (Figure 4). Although these assignments cannot resolve the difference between closely related human pathogens, human commensals, and free-living environmental species or strains within the genera, the presence and distribution of these groups are of interest because some of their ecological dynamics are likely shared with the pathogens of interest. At Avalon, these pathogen-related sequence tags accounted for a $0.798 \%$ of all sequence tags taxonomically assigned to bacteria from the water samples, $0.132 \%$ of the wet sand tags and $0.146 \%$ of the dry sand. At Provincetown, pathogen-related tag sequences accounted for about $0.724 \%$ of total water samples, $0.039 \%$ of wet sand tags and $0.065 \%$ of dry sand sequence tags. At both sites, water samples were also richer in pathogen-related sequence tags than the sand samples were. Comparing the similarity between and within samples grouped by factor confirmed that sample type (water vs. sand) produced the strongest significant differences between groups (one-way ANOSIM, $\mathrm{R}=0.532, \mathrm{p}=0.001$ ) whereas sample site (Avalon vs. Provincetown) was a weak but significant $(\mathrm{R}=0.289, \mathrm{p}=0.006)$ factor. Grouping based on whether samples were collected during a water quality violation event were not at all significantly different. These data suggest that pathogen-containing genera may be more capable of exploiting environmental niches in water or sand habitats than the alternative fecal indicators, and that the pathogen-containing genera that exploit sand and/or water at both sites are likely natural constituents of the environmental community.

All of the water samples collected during exceedance events at both sites contained tags assigned to the genus Enterococcus. Some of the Enterococcus tags from Avalon also had a species level 
assignation (E. ratii and E. colombae) corresponding to GenBank sequence acquisitions from studies of unhealthy rats and pigeons, respectively. Although sands were often enriched in culturable Enterococcus compared to water (Table 1), only a single sand sample (Avalon dry sand, day of exceedance) contained Enterococcus sequence tags.

The distribution of potential pathogen and Enterococcus tags present in water and sands between sites and over time is shown in Figure 4. Avalon water samples were notable for containing several different pathogenic Aeromonas spp., as well as the only sequence tags identified as Streptococcus pneumonia and the opportunistic human commensal Staphylococcus epidermis. Nearly all of Avalon sand and water had Clostridium spp., and Avalon sands also hosted the only tags classified as Leptospira and Treponema.. Provincetown water samples were notable for the ubiquity of Campylobacter spp. including one sample that had tags identified as $C$. jejuni that coincided with the presence of Eschericia coli tags most closely related to enterotoxigenic sequence acquisitions in GenBank. Provincetown sands hosted Clostridium spp. fairly consistently, including tags taxonomically identified as C. perfringens and C. botulinum. Provincetown waters had Clostridium spp. and Aeromonas spp. the day after the wet-weather water quality exceedance event.

Some pathogen-containing genera had a cosmopolitan distribution among all samples, but within those genera known pathogen spp. were infrequently recovered. For example, tags assigned to the genera Legionella and Francisella were recovered from all sample types at both locations, but were most likely contributed by nonpathogenic environmental bacteria; in contrast, sequence tags taxonomically identified as L. pneumophila or F. tularensis were sporadically recovered from Provincetown wet sands. 
Figure 4: Sequence tags assigned to pathogen-containing genera among days sampled, site and sample type

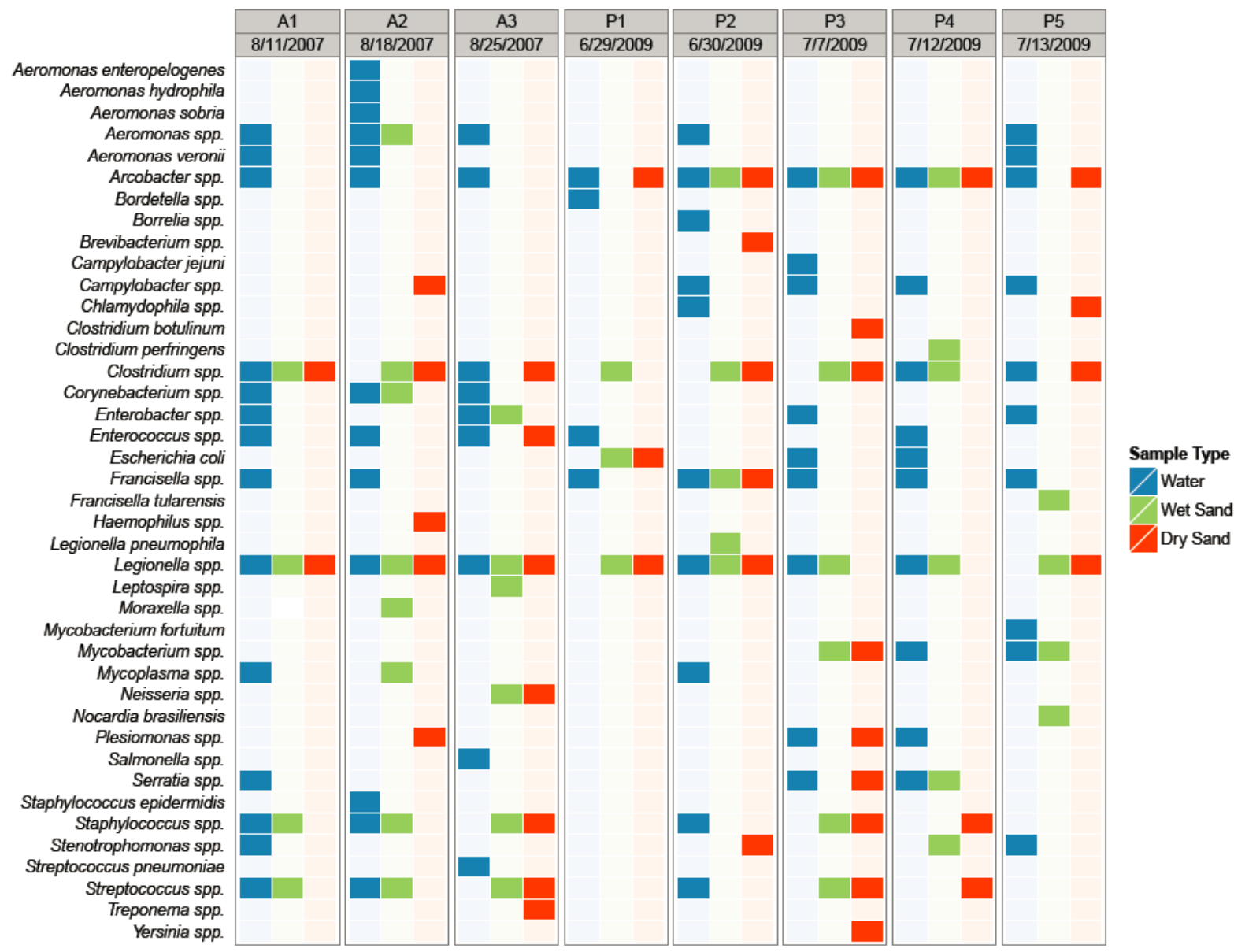

\section{Discussion}

Intertidal sands and the overlying water proved to have distinct bacterial communities, with greater similarity observed between coastal water samples from two distant sites than between the tidally mixed water and sand from the same site. Among wet and dry sand samples, the beach with a greater tidal range also exhibited greater dissimilarity between wet and dry sand bacterial communities. At this beach (Provincetown), temperature and daily tidal range appeared to explain some of the variation in community structure in water and dry sand samples. 
The majority of beach sand sequence tags from both locations belonged to the Acidobacteria, Actinobacteria, Bacteroidetes, Proteobacteria and the Planctomycetes. These are broadly similar to soil communities, as $>90 \%$ of sequence tags from soils collected around the world have been have been classified within the Actinobacteria, Acidobacteria, Proteobacteria, Bacteroidetes and Firmicutes, with the relative abundance of these groups within samples strongly influenced by soil $\mathrm{pH}$ (31). In particular, beach sand communities are differentiated from both coastal seawater and soil by the relative abundance of the Planctomycetes, which at both sites are relatively more abundant in wet sand than dry sand. The enrichment of the Planctomycetes in wet beach sands may reflect this phyla's frequent affiliation with organic detritus in the marine environment or participation in chitin degredation (14).

In contrast to total community, as a group the alternative fecal indicators were more similar among the sand and water collected at the same site, supporting the theory that while each of these beaches may be anthropogenically impacted, there are likely regional differences in sewage profiles. The complexity of the alternative indicators in environmental samples compared to sewage makes it difficult to interpret the very minor overlap of a few specific sequence tags and may be suggestive of diffuse nonpoint source pollution. The differences observed within the potential pathogen dataset offer further insight into the pollution impacting each beach. For example, Clostridium, Streptococcus, Corynebacterium and pathogenic Aeromonas spp. were consistently present among Avalon water and sand samples, and these sequence tags were also the most abundant among potential pathogen sequence tags from wastewater treatment plant influent, effluent, and activated sludge (52). The presence of the alternative fecal indicator groups, along with the Roseburia spp. tag, are suggestive of human contribution to the environment; these tags were not normally present in the natural communities. 
Pathogen-related tags were also routinely recovered at Provincetown (including pathogenic Clostridium spp. in sands), but as a group they are dominated by genera known to persist in the environment and within zoonotic reservoirs, such as such as Arcobacter, Campylobacter, Mycobacterium and many of the Enterobacteriaceae (E. coli, Plesiomonas, Serratia, Yersinia). Campylobacter spp. were recovered from nearly all of the Provincetown water samples, but did not correspond to water quality violations and were not recovered from the sand samples. Campylobacter is the leading cause of diarrhea in humans in the United States (2), and although long considered incapable of surviving outside the gut (30), it has been recovered from surface waters (24), sands $(37,50)$, and wrack(28), often with poor correlation to fecal indicator abundance. Avian wildlife are often an environmental reservoir of Campylobacter $(29,39,46)$, as can be domesticated and wild mammals $(38,40)$.

Overall, the water samples at both sites had a higher relative percentage of pathogen-related tags than sands, which could reflect a potential sampling bias due to differences in total cell abundance in these sample types. Still, it may lend support to other findings that pathogens in sands are not routinely present at high enough abundance to be problematic for those with robust immune systems (41). Pathogen-related tags accounted for $0.8 \%$ of tags from Avalon water samples and $0.724 \%$ of tags from Provincetown water samples, and the wet and dry sands at Avalon had a greater relative abundance of pathogen-related sequence tags $(0.15 \%$ of total sequence tags) than the sands at Provincetown $(0.05 \%)$. These relative abundances can be compared to activated sludge from municipal wastewater treatment plants, where sequence tags closely related to known pathogenic sequences accounted for approximately $0.16 \%$ of the total sequence tags (52). 
Although massively-parallel pyrosequencing tags of rDNA hypervariable regions provide unprecedented depth of sampling within the bacterial community, the short length of the sequence tags precludes identification of the majority of sequence tags to genera. It simply cannot reliably differentiate between strains, which is often the level of identification required to determine human health risk among a species of bacteria. Sequence tags from the indicator Enterococcus were recovered on days that had exceeded water quality standards, but the rarity of Enterococcus in this and other pyrosequencing datasets $(11,35)$ illustrates how the concentrations of indicators that cause concern from a monitoring perspective are relatively rare within the total community and not predictive of fecal bacteria in general (at least, based on this group of alternative indicators) or pathogen-related sequence tags.

Despite those setbacks, this study adds to the growing evidence that the community-based molecular tools used by microbial ecologists to study spatial and temporal variation and environmental disturbance events can be leveraged to study the sources and potential human health risks of fecal microbial pollution in the environment. In other studies, 16S-based pyrosequencing approaches have been used to broadly survey potential risks within sewage sludge and biosolids (4) and wastewater treatment plant samples (52), and with time these kinds of analyses can be completed with a broader range of potential source material. In terms of sourcing fecal pollution from animals or humans in surface waters, several community-based approaches have been developed that are analogous to current library-based microbial source tracking of single indicators (42). For example, similarities of T-RFLP profiles of a coastal creek and potential human and animal fecal sources have been used to identify fecal sources and the extent to which contamination upstream impacts sites downstream (8). In a case involving a limited number of environmental and local source samples, pyrosequencing of 16S rDNA 
derived from human and animal feces was used to examine the overlap between fecal sources and surface water communities, thereby discriminating which were likely dominant source material to the river (45). Various approaches have also been used to identify constituent groups of human-specific fecal bacteria in environmental samples, including the pyrosequencing approach that was the basis for the group of alternative fecal indicators we analyzed in this study (35), as well as alternative approaches such as amplification of the V3 region of 16S rDNA combined with capillary-electrophoresis single strand conformation polymorphism (C-ESSCP) to fingerprint human feces and sewage effluents and identify dominant, human-specific bacteria (47). However, previous studies have not considered the fecal fingerprint of sand, sediment, or wrack, which we begin to survey here and which can contribute to nonpoint source pollution at beaches. Further application of community-based methods to a wide array of environmental samples, sources and reservoirs may ultimately contribute to the diagnoses of bacterial pollution from unknown sources at beaches and in surface waters.

Acknowledgments: This work was supported by the National Science Foundation grant OCE0430724, and the National Institute of Environmental Health Sciences grant P50ES012742 to the Woods Hole Center for Ocean and Human Health. E. Halliday was partially supported by WHOI Academic Programs and grants from the WHOI Ocean Ventures Fund and the WHOI Coastal Ocean Institute. We would like to thank John Griffith and Yiping Cao of the Southern Califronia Coastal Water Research Project (SCCWRP) for beach sand samples from Avalon Bay Beach. 
References:

1. Abdelzaher, A. M., M. E. Wright, C. Ortega, H. M. Solo-Gabriele, G. Miller, S. Elmir, X. Newman, P. Shih, J. A. Bonilla, and T. D. Bonilla. 2010. Presence of pathogens and indicator microbes at a non-point source subtropical recreational marine beach. Appl Environ Microbiol 76:724.

2. Altekruse, S. F., N. J. Stern, P. I. Fields, and D. L. Swerdlow. 1999. Campylobacter jejuni--an emerging foodborne pathogen. Emerging infectious diseases 5:28.

3. Beversdorf, L. J., S. M. Bornstein-Forst, and S. L. McLellan. 2007. The potential for beach sand to serve as a reservoir for Escherichia coli and the physical influences on cell die-off. J Appl Microbiol 102:1372-1381.

4. Bibby, K., E. Viau, and J. Peccia. 2010. Pyrosequencing of the 16S rRNA gene to reveal bacterial pathogen diversity in biosolids. Water Res 44:4252-4260.

5. Böer, S. I., S. I. C. Hedtkamp, J. E. E. Van Beusekom, J. A. Fuhrman, A. Boetius, and A. Ramette. 2009. Time-and sediment depth-related variations in bacterial diversity and community structure in subtidal sands. Isme J 3:780-791.

6. Bonilla, T. D., K. Nowosielski, M. Cuvelier, A. Hartz, M. Green, N. Esiobu, D. S. McCorquodale, J. M. Fleisher, and A. Rogerson. 2007. Prevalence and distribution of fecal indicator organisms in South Florida beach sand and preliminary assessment of health effects associated with beach sand exposure. Mar Pollut Bull 54:1472-1482.

7. Byappanahalli, M., and R. Fujioka. 2004. Indigenous soil bacteria and low moisture may limit but allow faecal bacteria to multiply and become a minor population in tropical soils. Water science and technology: a journal of the International Association on Water Pollution Research 50:27.

8. Cao, Y., L. C. Van De Werfhorst, B. Sercu, J. L. S. Murray, and P. A. Holden. 2011. Application of an Integrated Community Analysis Approach for Microbial Source Tracking in a Coastal Creek. Environmental science \& technology 45:7195-7201.

9. Clarke, K., and R. M. Warwick. 2001. Changes in marine communities: an approach to statistical analysis and interpretation.

10. Dethlefsen, L., S. Huse, M. L. Sogin, and D. A. Relman. 2008. The pervasive effects of an antibiotic on the human gut microbiota, as revealed by deep $16 \mathrm{~S}$ rRNA sequencing. PLoS biology 6:e280.

11. Dowd, S. E., T. R. Callaway, R. D. Wolcott, Y. Sun, T. McKeehan, R. G. Hagevoort, and T. S. Edrington. 2008. Evaluation of the bacterial diversity in the feces of cattle using 16 S rDNA bacterial tag-encoded FLX amplicon pyrosequencing(bTEFAP). BMC microbiology 8:125.

12. Elmanama, A. A., M. I. Fahd, S. Afifi, S. Abdallah, and S. Bahr. 2005. Microbiological beach sand quality in Gaza Strip in comparison to seawater quality. Environ Res 99:1-10.

13. Feng, F., D. Goto, and T. Yan. 2010. Effects of autochthonous microbial community on the dieoff of fecal indicators in tropical beach sand. FEMS Microbiol Ecol 74:214-225.

14. Fuerst, J. A. 1995. The planctomycetes: emerging models for microbial ecology, evolution and cell biology. Microbiology 141:1493.

15. Gast, R. J., M. R. Dennett, and D. A. Caron. 2004. Characterization of protistan assemblages in the Ross Sea, Antarctica, by denaturing gradient gel electrophoresis. Appl Environ Microbiol 70:2028.

16. Ge, Z., R. L. Whitman, M. B. Nevers, M. S. Phanikumar, and M. N. Byappanahalli. 2012. Nearshore hydrodynamics as loading and forcing factors for Escherichia coli contamination at an embayed beach. Limnology and Oceanography 57:362. 
17. Gobet, A., S. I. Boer, S. M. Huse, J. E. E. van Beusekom, C. Quince, M. L. Sogin, A. Boetius, and A. Ramette. 2012. Diversity and dynamics of rare and of resident bacterial populations in coastal sands. Isme J 6:542-553.

18. Gobet, A., C. Quince, and A. Ramette. 2010. Multivariate Cutoff Level Analysis (MultiCoLA) of large community data sets. Nucleic Acids Res 38:e155.

19. Halliday, E., and R. J. Gast. 2011. Bacteria in Beach Sands: An Emerging Challenge in Protecting Coastal Water Quality and Bather Health. Environmental science \& technology.

20. Halliday, E., J. F. Griffith, and R. J. Gast. 2010. Use of an exogenous plasmid standard and quantitative PCR to monitor spatial and temporal distribution of Enterococcus spp. in beach sands. Limnol. Oceanogr. Methods 8:146-154.

21. Hartz, A., M. Cuvelier, K. Nowosielski, T. D. Bonilla, M. Green, N. Esiobu, D. S. McCorquodale, and A. Rogerson. 2008. Survival potential of Escherichia coli and Enterococci in subtropical beach sand: implications for water quality managers. J Environ Qual 37:898-905.

22. Heaney, C. D., E. Sams, A. P. Dufour, K. P. Brenner, R. A. Haugland, E. Chern, S. Wing, S. Marshall, D. C. Love, and M. Serre. 2012. Fecal Indicators in Sand, Sand Contact, and Risk of Enteric Illness Among Beachgoers. Epidemiology 23:95.

23. Heaney, C. D., E. Sams, S. Wing, S. Marshall, K. Brenner, A. P. Dufour, and T. J. Wade. 2009. Contact with beach sand among beachgoers and risk of illness. American journal of epidemiology 170:164.

24. Hellein, K. N., C. Battie, E. Tauchman, D. Lund, O. A. Oyarzabal, and J. E. Lepo. 2011. Culturebased indicators of fecal contamination and molecular microbial indicators rarely correlate with Campylobacter spp. in recreational waters. Journal of water and health 9:695.

25. Hewson, I., G. Vargo, and J. Fuhrman. 2003. Bacterial diversity in shallow oligotrophic marine benthos and overlying waters: effects of virus infection, containment, and nutrient enrichment. Microbial ecology 46:322-336.

26. Huber, J. A., D. B. Mark Welch, H. G. Morrison, S. M. Huse, P. R. Neal, D. A. Butterfield, and M. L. Sogin. 2007. Microbial population structures in the deep marine biosphere. science 318:97.

27. Huse, S. M., J. A. Huber, D. M. Welch, D. A. Relman, and M. L. Sogin. 2008. Exploring microbial diversity and taxonomy using SSU rRNA hypervariable tag sequencing. PLoS genetics 4:e1000255.

28. Ishii, S., T. Yan, D. A. Shively, M. N. Byappanahalli, R. L. Whitman, and M. J. Sadowsky. 2006. Cladophora (Chlorophyta) spp. harbor human bacterial pathogens in nearshore water of Lake Michigan. Appl Environ Microbiol 72:4545-4553.

29. Kapperud, G., and O. Rosef. 1983. Avian wildlife reservoir of Campylobacter fetus subsp. jejuni, Yersinia spp., and Salmonella spp. in Norway. Appl Environ Microbiol 45:375-380.

30. Ketley, J. M. 1997. Pathogenesis of enteric infection by Campylobacter. Microbiology 143:5-21.

31. Lauber, C. L., M. Hamady, R. Knight, and N. Fierer. 2009. Pyrosequencing-based assessment of soil $\mathrm{pH}$ as a predictor of soil bacterial community structure at the continental scale. Appl Environ Microbiol 75:5111.

32. Laverock, B., C. J. Smith, K. Tait, A. M. Osborn, S. Widdicombe, and J. A. Gilbert. 2010. Bioturbating shrimp alter the structure and diversity of bacterial communities in coastal marine sediments. Isme J 4:1531-1544.

33. Llobet-Brossa, E., R. Rosselló-Mora, and R. Amann. 1998. Microbial community composition of Wadden Sea sediments as revealed by fluorescence in situ hybridization. Appl Environ Microbiol 64:2691-2696.

34. Ludwig, W., and K. H. Schleifer. 2000. How quantitative is quantitative PCR with respect to cell counts? Systematic and applied microbiology 23:556. 
35. McLellan, S., S. Huse, S. Mueller Spitz, E. Andreishcheva, and M. Sogin. 2010. Diversity and population structure of sewage derived microorganisms in wastewater treatment plant influent. Environ Microbiol 12:378-392.

36. Mika, K. B., G. Imamura, C. Chang, V. Conway, G. Fernandez, J. F. Griffith, R. A. Kampalath, C. M. Lee, C. C. Lin, and R. Moreno. 2009. Pilot-and bench-scale testing of faecal indicator bacteria survival in marine beach sand near point sources. J Appl Microbiol 107:72-84.

37. Obiri-Danso, K., and K. Jones. 2000. Intertidal sediments as reservoirs for hippurate negative campylobacters, salmonellae and faecal indicators in three EU recognised bathing waters in North West England. Water Res 34:519-527.

38. Petersen, L., E. Nielsen, J. Engberg, S. L. W. On, and H. Dietz. 2001. Comparison of genotypes and serotypes of Campylobacter jejuni isolated from Danish wild mammals and birds and from broiler flocks and humans. Appl Environ Microbiol 67:3115-3121.

39. Quessy, S., and S. Messier. 1992. Prevalence of Salmonella spp., Campylobacter spp. and Listeria spp. in ring-billed gulls (Larus delawarensis). Journal of wildlife diseases 28:526-531.

40. Rosef, O., G. Kapperud, S. Lauwers, and B. Gondrosen. 1985. Serotyping of Campylobacter jejuni, Campylobacter coli, and Campylobacter laridis from domestic and wild animals. Appl Environ Microbiol 49:1507-1510.

41. Shibata, T., and H. M. Solo-Gabriele. 2012. Quantitative Microbial Risk Assessment of Human Illness from Exposure to Marine Beach Sand. Environmental science \& technology.

42. Simpson, J. M., J. W. Santo Domingo, and D. J. Reasoner. 2002. Microbial Source Tracking: State of the Science. Environmental science \& technology 36:5279-5288.

43. Tšertova, N., A. Kisand, H. Tammert, and V. Kisand. 2011. Low seasonal variability in community composition of sediment bacteria in large and shallow lake. Environmental Microbiology Reports 3:270-277.

44. U.S.E.P.A. 2002. Method 1600: membrane filter test method for enterococci in water.

45. Unno, T., J. Jang, D. Han, J. H. Kim, M. J. Sadowsky, O. S. Kim, J. Chun, and H. G. Hur. 2010. Use of Barcoded Pyrosequencing and Shared OTUs To Determine Sources of Fecal Bacteria in Watersheds. Environmental science \& technology.

46. Waldenström, J., T. Broman, I. Carlsson, D. Hasselquist, R. P. Achterberg, J. A. Wagenaar, and B. Olsen. 2002. Prevalence of Campylobacter jejuni, Campylobacter lari, and Campylobacter coli in different ecological guilds and taxa of migrating birds. Appl Environ Microbiol 68:5911-5917.

47. Wéry, N., C. Monteil, A.-M. Pourcher, and J.-J. Godon. 2010. Human-specific fecal bacteria in wastewater treatment plant effluents. Water Res 44:1873-1883.

48. Wheeler Alm, E., J. Burke, and A. Spain. 2003. Fecal indicator bacteria are abundant in wet sand at freshwater beaches. Water Res 37:3978-3982.

49. Yamahara, K. M., B. A. Layton, A. E. Santoro, and A. B. Boehm. 2007. Beach sands along the California coast are diffuse sources of fecal bacteria to coastal waters. Environmental science \& technology 41:4515-4521.

50. Yamahara, K. M., L. M. Sassoubre, K. D. Goodwin, and A. B. Boehm. 2012. Occurrence and Persistence of Bacterial Pathogens and Indicator Organisms in Beach Sand along the California Coast. Appl Environ Microbiol 78:1733-1745.

51. Yamahara, K. M., S. P. Walters, and A. B. Boehm. 2009. Growth of enterococci in unaltered, unseeded beach sands subjected to tidal wetting. Appl Environ Microbiol 75:1517.

52. Ye, L., and T. Zhang. 2011. Pathogenic Bacteria in Sewage Treatment Plants as Revealed by 454 Pyrosequencing. Environmental science \& technology.

53. Zhu, X., J. D. Wang, H. M. Solo-Gabriele, and L. E. Fleming. 2011. A water quality modeling study of non-point sources at recreational marine beaches. Water Res. 


\section{CHAPTER 7: CONCLUSIONS}

\subsection{Sands are a reservoir of enterococci at marine beaches}

Results from the beaches in Wells, Me and along the harbor of Provincetown, MA, add data points from northeastern marine temperate beaches to the accumulating evidence that fecal indicators can accumulate in beach sands, as described in Chapter 2. All sands sampled around the mean high tide line in the upper intertidal were, on average, enriched in enterococci relative to lower intertidal sands by up to an order of magnitude. Intertidal sands host enterococci at levels that are appreciably higher than levels found in the water.

The consistency of the patterns observed between wet sand and dry sand CFU were striking. Water, wet sand, and dry sand all were elevated during rainy seasons compared to dry seasons, as illustrated in Chapter 5, but maintained the pattern of distribution observed during dry seasons. Equally striking were how qPCR enterococci CE in sands deviated from this pattern, with no significant difference observed between wet and dry sands at any of the sites at Wells or Provincetown. The amount of DNA in sands, especially when corrected for efficiency of the extraction protocol, was several orders of magnitude higher than the amount of culturable cells in the same sands. These ratios fall within a similar range as has been observed in other studies using natural sands (11). In future work, it would be interesting to determine whether a proportion of the high amounts of enterococci DNA in sands comes from cells that are cyclically reanimated from the viable but nonculturable state, perhaps as a function of moisture availability, or whether assumptions of enterococci gene copy number bias the estimated cell equivalencies.

From a monitoring perspective, the major significance of sands as a reservoir of enterococci is that these bacteria can contribute to water quality. Although densities of enterococci in sands at 
Provincetown appear to be unlikely to cause an exceedance event independently, settling into and resuspension from sands could dampen or increase monitoring results, pushing a water sample over or under the single sample limit. The environmental variable of water level is incorporated in nearly every model of water quality from the different environments and timescales included in Chapters 4 and 5, implicating tidal oscillations in the mobilization of enterococci from sands to water. Tidal cycles are not taken into account in monitoring schemes and could be contributing a bias to routine sampling.

Based on this work and the work of others, Figure 1 presents a conceptual model of FIB in the coastal zone. Loads to the beach (arrows \#1, \#2,\#3) would include stormwater discharged onto sands and/or into water, the relative contributions from different animals on the beach (9), illegal boat discharge to the water, and loads from leaking septic and sewage systems which might be entering water or groundwater (arrow \#7).

The number of FIB in each compartment increases or decreases over time due to growth or decay; rates that have been experimentally measured and modeled for E. coli and Enterococcus within the compartments of dry sand, wet sand and water were reviewed in Chapter 2, Table 1. Chapters 4 and 5 provide evidence from field studies that persistence in dry sand is likely a function of moisture content, solar insolation, and relative humidity, and in water may be a function of temperature, salinity and possibly turbidity. At beaches with a subsurface sand/water/groundwater mixing zone, the growth or decay of bacteria in pore waters with intermediate salinities remains unknown. FIB survival in groundwater may be a function of temperature, groundwater chemistry, competition with indigenous bacteria and predation by protists, flow rate and retention within pore spaces. 
Figure 1: Conceptual model of intertidal loads and fluxes impacting concentrations of FIB in coastal bathing waters

Depicted below are five storage compartments for FIB within the coastal zone. Red arrows represent fluxes into and out of the system from external sources, and white arrows represent fluxes between the compartments within the system. The dry sand compartment is representative of the surficial sands (upper $10 \mathrm{~cm}$ ) between mean high and high-high tide lines, and the wet sand compartment is representative of surficial sands between mean high and mean low tide lines. The mixing zone compartment represents intertidal sands below the surface which are impacted by seawater infiltration and may interact with fresh groundwater. FIB growth/death rates are specific to and important within each compartment.

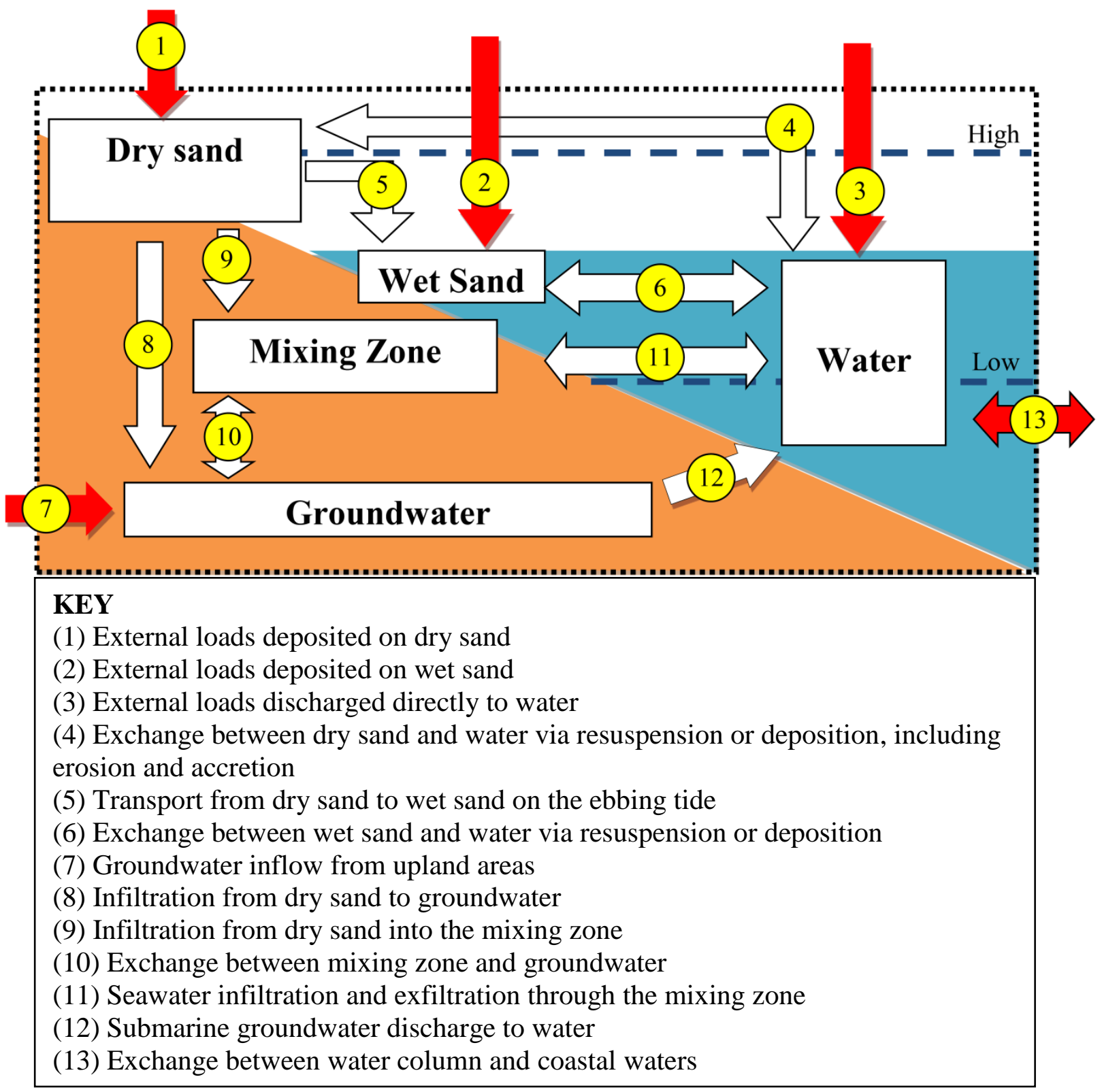




\section{Figure 2: Patterns of bacterial contamination can be identified when FIB measurements}

are supplemented with data characterizing the water, weather, site and regional cycles.

Environmental parameters that are easily collected in the field when testing FIB (green) or that are easily available from other sources (purple) have successfully been used as predictive variables in statistical models of FIB at beaches; parameters listed in black are less likely to be locally available but have been found to be strongly related to FIB at many beaches. "Site" and "Cycles" refer to the variables that may distinguish one beach or region from another - due to the physical setup or annual trends.

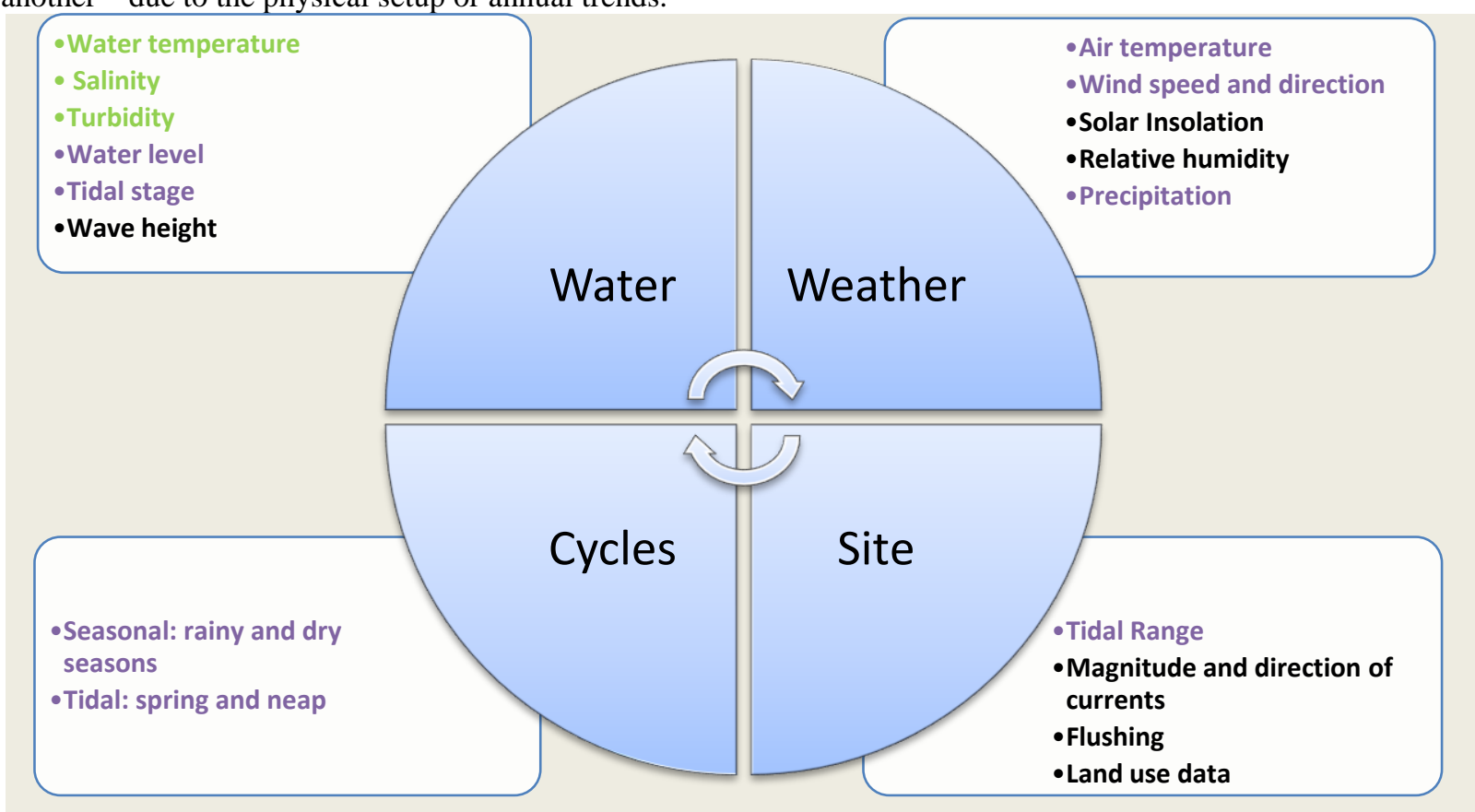

A digital thermometer can be included with sampling gear for volunteer monitors, and a handheld refractometer and turbidometer can be kept at the lab or carried in the field so that an aliquot of sample can be tested for salinity and turbidity prior to FIB processing. The free program Wtides (http://www.wtides.com) predicts and plots tides (past and present) at beaches worldwide. Weather stations can be maintained at beaches to collect data, or data from nearby weather stations can be accessed through the National Climate Data Center (www.ncdc.noaa.gov/DCO/cdodata.cmd). 
More work is needed to constrain the fluxes within the system. Experiments presented in Appendix A examine the exchange of enterococci from contaminated sand to water under calm and turbulent conditions. Preliminary results showed that under quiescent conditions enterococci moved from the high-concentration compartment to the low-concentration compartment. Under turbulent conditions created by placing sand/water microcosms on a shaker at 50 or 100RPM, more enterococci were released when sands were shaken than were released under quiescent conditions. Increased shaking speed increased the average amount of enterococci released from sand to water, as well as the turbidity of the water, within the first ten minutes of a thirty-minute time course. These data suggest that different equilibrium conditions between sand and water (e.g., arrows \#4 and \#6 in Figure 1) could be modeled based on the concentration in each compartment, and by identifying and monitoring the locally relevant mechanisms driving resuspension (wind speed and direction, wave height, tidal velocity, etc.). Likewise, laboratory experiments using sand columns flushed with seawater have provided estimates of throughbeach transfer from dry sand to groundwater (4), and models based on field and laboratory observations indicate detachment of bacteria occurs when pore water content rapidly increases, leading to air-water interface scouring and thin-film expansion. Experiments like these can approximate exchange denoted in arrow \#8 and \#9 in Figure 1. Evidence suggests both indicators and pathogens can be mobilized by these mechanisms (10), highlighting the importance of studying these mechanisms in different sand types, under different environmental conditions, and in the context of different physical settings. Similarly, erosion and accretion of sands at coastal beaches can bury or expose contaminated sands (Gast et al., in prep).

Nearshore dynamics not only impact the exchange between sands and water, but also the exchange between the surfzone water column and the water body at large (arrow \#13). 
Understanding these processes requires site-specific quantification of long and cross-shore current magnitude and direction, approximations of residence time in embayed beaches, and how these measurements change over time. Modeling the loads from open and nearshore water at an embayed beach along the Great Lakes showed the beach was a sink of E. coli; cycles of deposition and resuspension likely impact bathing water quality at the site, and simulations suggest that increased circulation at the embayed beach would result in fewer exceedance events (1).

7.2 Environmental variables influence the distribution of enterococci in sands and water at beaches in Massachusetts and Maine

Results from Chapter 4 illustrated that qPCR CE and CFU respond on different timescales to environmental stimuli like precipitation events, and CE are routinely at least an order of magnitude greater than CFU, making it difficult to directly interpret whether qPCR CE exceed the culture-based single sample standard. The EPA has recently introduced the draft of a standardized method for monitoring coastal waters based on detection of enterococci via qPCR (8), and that will establish acceptable limits for enterococci DNA in the environment. The results presented in Chapter 4 suggest these different monitoring methods are not interchangeable on a day-to-day basis.

Whether culture-based or molecular methods are utilized to monitor enterococci in coastal waters, collecting environmental data in situ can greatly enhance the interpretation of routine monitoring measurements. With the exception of turbidity at Provincetown, all the environmental variables that had the strongest relationship to enterococci in sand and water were averaged over the past 24 hours. Even in the dynamic combination of tidal rivers and Atlantic 
Ocean, one in-situ water quality sensor was quite useful for determining environmental factors important at several beaches. However, as described in Figure 2, any additional environmental data can contribute to the understanding of how FIB abundance varies at a site or within a region.

\subsection{Relating enterococci abundance and nonpoint source pollution to human health risks}

Chapters 4, 5 and 6 each use different methods to make preliminary inquiries into the relationship between enterococci and gastrointestinal pathogens in sands. In Chapter 4, the sands at Wells beaches that had higher mean enterococci during the sampling period also had more frequent recovery of Campylobacter jejuni from their DNA samples, indicating that sands enriched in enterococci may be associated with greater health risk. This seems to support the initial epidemiological studies of enterococci in sand, which showed outcomes of illness increased with more extensive exposure to sands, and also were greater in sands with higher densities of enterococci $(2,3)$. However, a recent quantitative microbial risk assessment translated the regulatory levels of pathogens in water to an equivalent level of pathogens in sand, and showed that pathogens in subtropical sands were below the levels that would be expected to cause significant negative health outcomes (7). Because illnesses contracted at beaches may not be recognized as such by patients and doctors, more targeted epidemiological studies are needed to establish the level of contamination that presents cause for concern at beaches, and continue to characterize which pathogens and routes of exposure contribute to the highest risks associated with beach sands.

In Chapter 5, a marker of human fecal contamination was found in waters, but not sands, and did not co-occur with higher mean enterococci or water quality exceedance events. Based on the recurring detection of the human fecal Bacteroides marker during neap tides, it was hypothesized 
to be a signature of fresh, anthropogenically contaminated groundwater. This was an unanticipated result and unfortunately, because the sampling scheme was designed to study variation of ENT in surficial sands, groundwater samples were not collected and so it is not possible to comment on the concentrations or viability of indicators or pathogens associated with this source to bathing waters. The data do illustrate the decoupling of the human fecal signature from qPCR or CFU measurements, suggesting that fecal indicators and pathogens may have different attenuation rates in the environment and when transported through different environmental matrices at beaches. The first laboratory studies to examine persistence of a suite of pathogens and indicators in beach sands has documented differential persistence over time, as well as differences in decay rates of culturable cells and molecular markers (10). More work is required to determine whether enterococci or the human fecal indicator are useful indicators of pathogens in sands.

The human fecal Bacteroides marker has successfully been used in a variety of applications as a library-independent source-tracking method $(5,6)$. In Chapter 6 , community profiles generated through 454 sequencing suggest although Avalon and Provincetown both are impacted by fecal pollution, the kinds of fecal bacteria and potential pathogen sequence tags found in sand and water reflect the unique combination of local sources impacting each beach. Although the sequence tags recovered from samples represent both viable and dead cells or naked DNA, they do suggest there can be different combinations of risk. 


\subsection{References}

1. Ge, Z., R. L. Whitman, M. B. Nevers, M. S. Phanikumar, and M. N. Byappanahalli. 2012. Nearshore hydrodynamics as loading and forcing factors for Escherichia coli contamination at an embayed beach. Limnology and Oceanography 57:362.

2. Heaney, C. D., E. Sams, A. P. Dufour, K. P. Brenner, R. A. Haugland, E. Chern, S. Wing, S. Marshall, D. C. Love, and M. Serre. 2012. Fecal Indicators in Sand, Sand Contact, and Risk of Enteric Illness Among Beachgoers. Epidemiology 23:95.

3. Heaney, C. D., E. Sams, S. Wing, S. Marshall, K. Brenner, A. P. Dufour, and T. J. Wade. 2009. Contact with beach sand among beachgoers and risk of illness. American journal of epidemiology 170:164.

4. Russell, T., K. M. Yamahara, and A. B. Boehm. 2012. Mobilization and transport of naturally occurring enterococci in beach sands subject to transient infiltration of seawater. Environmental science \& technology.

5. Santoro, A. E., and A. B. Boehm. 2007. Frequent occurrence of the human-specific Bacteroides fecal marker at an open coast marine beach: relationship to waves, tides and traditional indicators. Environ Microbiol 9:2038-2049.

6. Sercu, B., L. C. V. D. Werfhorst, J. Murray, and P. A. Holden. 2008. Storm drains are sources of human fecal pollution during dry weather in three urban southern California watersheds. Environmental science \& technology 43:293-298.

7. Shibata, T., and H. M. Solo-Gabriele. 2012. Quantitative Microbial Risk Assessment of Human Illness from Exposure to Marine Beach Sand. Environmental science \& technology.

8. U.S.E.P.A. 2011. Recreational Water Quality Criteria. In O. o. Water (ed.), Washington, D.C.

9. Wright, M. E., H. M. Solo-Gabriele, S. Elmir, and L. E. Fleming. 2009. Microbial load from animal feces at a recreational beach. Mar Pollut Bull 58:1649-1656.

10. Yamahara, K. M., L. M. Sassoubre, K. D. Goodwin, and A. B. Boehm. 2012. Occurrence and Persistence of Bacterial Pathogens and Indicator Organisms in Beach Sand along the California Coast. Appl Environ Microbiol 78:1733-1745.

11. Yamahara, K. M., S. P. Walters, and A. B. Boehm. 2009. Growth of enterococci in unaltered, unseeded beach sands subjected to tidal wetting. Appl Environ Microbiol 75:1517. 


\section{Appendix A: Laboratory experiments examining transfer of enterococci (ENT) from sand}

\section{to water}

Examining evidence of ENT exchange between sand and water in environmental data collected at Provincetown

To monitor the amount of ENT in sand samples, sands are vigorously shaken in sterile buffered saline solution to dislodge attached bacteria from sands and into sterile phosphate buffered saline; after allowing particles to settle back into the sand, an aliquot of the buffer is filtered as a water sample would for EPA method 1600, and then counts are normalized to the dry weight of the sand in order to estimate the total culturable ENT originally present in the sample.

It is assumed that the net transfer of ENT from sand to PBS that occurs due to vigorous shaking is different from the net transfer of ENT from sand to seawater under quiescent conditions or due to light or moderate turbulence. Studies comparing shaking methods suggest that shaking by hand for different time intervals does not produce significantly different results (Boehm, Griffith et al. 2009). Thus, a series of laboratory experiments were undertaken to test whether the same amount of ENT in contaminated sands are released to water under quiescent and turbulent conditions over time, or whether higher-energy conditions result in a greater proportion of ENT released from sands. The experimental design and results are presented in the Methods of this Appendix; briefly, they showed that with each treatment (quiescent, shaking at 50RPM, shaking at 100RPM) ENT would be released from sand. ENT were most rapidly released within the first 10 minutes of the 30-minute timecourse, and increased shaking resulted in a greater relative percentage of ENT in sands being released to the water. Under quiescent conditions approximately $1 \%$ of total ENT in sands were released into the water, and $16 \%$ of total ENT in 
sands were released into the water when shaken at 50RPM. At 50RPM, turbidity (5 Normalized Turbidity Units, or NTU) approximated the upper limit of environmental turbidities observed at Provincetown. Thus, $16 \%$ could be considered a rough upper limit of the relative proportion of ENT in sand that would be released to water in turbulent conditions at Provincetown.

Discounting any dilution in the environment, this would certainly be an upper limit.

The tidal mechanism that may explain the differences in mean ENT abundance observed at Provincetown and discussed in Chapter 5 is quite different from vigorous shaking. At the site, the calm conditions are reflected in turbidity measurements that were always less than 5NTU. If the total ENT measured right at the water line in water and sand were considered one population being exchanged between two environmental compartments, the amount of ENT in water might be looked at as a relative percentage of the intertidal ENT population. Were this the case, environmental samples with radically higher relative amounts of ENT in water relative to sand would be indicative of ENT sources beyond sands contributing to the water that morning (runoff, illicit dumping, fecal event, etc.). In addition, this relative percentage should vary as a function of tidal velocity, which could be approximated by absolute change in water level in the hour prior to sampling.

Environmental data from the morning spatial and temporal sampling are consistent with this framework of analysis. Samples were collected bracketing a high tide, during a lower-thanaverage tidal range of $8.5 \mathrm{ft}$ neap (Chapter 5, Table 1). At the end of the flood tide (8am) and the beginning of the ebb tide (12pm) the absolute change in water level was $0.8 \mathrm{ft} / \mathrm{hr}$ and the percentage of ENT in water relative to sand was $4.95 \%$ and $4.91 \%$, respectively. At 9 am and $11 \mathrm{am}$, the absolute change in water level was approximately $0.5 \mathrm{ft} / \mathrm{hr}$ and the relative percent of ENT in water was $2.32 \%$ and $2.16 \%$, and at $10 \mathrm{am}$ the change in water level was only $0.14 \mathrm{ft} / \mathrm{hr}$ 
and the relative amount of ENT in water was 1.4\%. Although the ENT concentrations in the water are low, this data confirms that a greater relative percentage of ENT are released from sands when tidal velocity is higher. It is also interesting to note that these relative percentages are well below the estimated upper limit of $16 \%$.

There was one day with an identifiable pollution event that occurred near the pier and provided additional proof-of-concept of the utility of this relative percentage statistic. The polluted sample was taken from a directly visible tongue of black water coming into the beach from further out in the harbor, and the sample had a concentration of ENT that was twice as high as the secondranking ENT concentration observed during the season. If the contaminated sample is eliminated from the five-site daily average, the relative percentage of ENT in water is $12 \%$. If the polluted sample is included, the relative percentage is $54 \%$, much higher than could be sourced by sands.

Days with an exceedance event had a higher relative percentage of ENT in water $(n=7$, mean $35.8 \%$, SEM $=9.9 \%)$ than days when all samples were below the limit $(n=25$, mean $14.0 \%$, $\mathrm{SEM}=2.6 \%$ ). Of the seven days that had at least one water sample in violation of the water quality standard, two days had a relative percentage of ENT in water within the "normal" range (11\% and $17 \%$ ) with no other presumptive sources present (i.e., no precipitation events and no HF marker present). These may be instances of "sand exceedances." The other four exceedances were much greater proportionally (ranging from $33.1-81.9 \%$ ), likely indicating sources beyond sands, including a precipitation event and possibly very high tides.

Regardless of water quality violations, days with tidal ranges greater than 9ft averaged $22.6 \%$ whereas days with tidal ranges less than $9 \mathrm{ft}$ averaged 11.6\%. Precipitation was occasionally but not always associated with higher relative percentage of ENT in water, and likewise the human 
fecal signature was occasionally but not always associated with a higher relative percentage of ENT in water.

\section{Methods}

\subsection{Experimental design and materials used in sand/water microcosms}

1.1.1 Experimental sands: Beach sands were collected from above the high tide line at 333 Commercial St. in September 2011 and stored for six months in an open bucket, as a reserve of sand from the site for lab-based experiments. Due to the irregular presence of seaweed and rocks in the sands, prior to the shaking experiments $2000 \mathrm{~g}$ were pre-sifted through a $2 \mathrm{~mm}$ sieve to prevent disparities in sand weight or nutrient availability within sand microcosm replicates and between treatments. Sands were not autoclaved, but subsampling confirmed the absence of viable ENT.

1.1.2 Spiking ENT into sand: An isolate of ENT recovered from Provincetown beach sands in 2010, confirmed by sequencing (16S) to be E. faecalis, was revived from a glycerol stock for use in these experiments. After suspending stock cells in BHI media and culturing overnight at $41 \mathrm{C}, 1 \mathrm{~mL}$ of the bacteria in solution were diluted in $10 \mathrm{~mL}$ milliQ water, which was then added to 500g dry beach sand. Sands were homogenized by stirring with a sterile spoon for two minutes, yielding contaminated sand with approximately $2 \%$ moisture content. After $24 \mathrm{~h}$ at room temperature, bacteria were enumerated from $1 \mathrm{~g}$ of sand by adding $10 \mathrm{~mL}$ sterile PBS and shaking by hand for 2 minutes, before removing $1 \mathrm{~mL}$ of PBS eluant to filter and plate on $\mathrm{mEI}$ (EPA 1600). Initial bacterial content was 
determined too high for shaking experiments (plates overgrown with colonies), and so contaminated sand was added to bacteria-free sand (1:10) and homogenized to produce sands with a lower starting quantity of bacteria. After homogenizing, this mixture was left to rest for an additional $24 \mathrm{~h}$ before beginning shaking experiments.

1.1.3 Microcosm water: 4L of coastal seawater were collected in Woods Hole $(\mathrm{PSU}=35)$ and autoclaved for use in shaking experiments the day before they were conducted.

\subsection{Sand transfer and shaking experiments}

1.2.1 For quality control, $10 \mathrm{~mL}$ autoclaved seawater and $10 \mathrm{~mL}$ autoclaved PBS were filtered at the beginning of each treatment to ensure lack of viable ENT in stock solutions.

1.2.2 Plastic 500mL Ehrlenmayer flasks contained a sand/water microcosm, duplicated for each treatment. $110 \mathrm{~g}$ of contaminated sand was weighed and added to each Ehrlenmayer flask, from which $10 \mathrm{~g}$ were subsampled directly prior to the addition of any seawater to the microcosm $(\mathrm{t}=0 \mathrm{~min})$, to determine the starting quantity of bacteria in sand. Bacteria in sands were enumerated by shaking in sterile PBS and plating the supernatant, as described above for environmental samples. The starting quantity of sand in the microcosm was reweighed, and then $100 \mathrm{~mL}$ of sterile seawater was gently added to the flask via pipette ( $\mathrm{t}=0 \mathrm{~min})$. Because the sand was dry, it took the addition of approximately $25 \mathrm{~mL}$ seawater before the sand was saturated. 
1.2.3 To test whether bacteria are transferred from contaminated sand to water under quiescent conditions, the flasks were left undisturbed on the lab bench for the 30min time course. To test whether there was transfer of bacteria from contaminated water to bacteria-free sands under quiescent conditions, water was contaminated with bacteria previously shaken off the sands. $5.5 \mathrm{~mL}$ of water was withdrawn via pipette from the water's surface at $\mathrm{t}=0 \mathrm{~min}, \mathrm{t}=10 \mathrm{~min}, \mathrm{t}=20 \mathrm{~min}$, and the endpoint $\mathrm{t}=30 \mathrm{~min}$. After water was subsampled at $\mathrm{t}=30 \mathrm{~min}$, remaining water $(50-60 \mathrm{~mL})$ was carefully poured off and the wet sand in the flask was reweighed. Then, $100 \mathrm{~mL}$ of PBS was added to the flask, and the sand was shaken by hand for two minutes and allowed to settle for one minute before $10 \mathrm{~mL}$ and $1 \mathrm{~mL}$ aliquots of the PBS were subsampled to enumerate sand bacteria.

\subsubsection{To test the hypothesis that transfer of bacteria from sand to water} increased with increasing energy, sets of duplicate flasks were set up and sampled in the same manner, but attached to a shaker for treatments of 50rpm and 100rpm. The shaker was held at a temperature of 25C (approximately $+/-1 \mathrm{C}$ from ambient room temperature). Water and sands were subsampled at the timepoints as described above, with flasks in the shaking treatments were brought to a standstill to subsample the water by pipette, immediately after which the shaker was turned back on. Aliquots of $5 \mathrm{~mL}$ and $500 \mathrm{uL}$ were filtered and plated to determine bacterial concentration in the water over time. 
2 Shaking experiments tested two hypotheses. The first hypothesis was that in a quiescent sand/water microcosm, in which one of the two compartments is contaminated with a known concentration of ENT (e.g., contaminated sand and clean water and visa versa), a proportion of bacteria would move from the compartment with high concentration sands to the compartment with low (i.e., zero) concentration. The second hypothesis deals with the transfer of ENT from sand to water, and specifically tests whether increasing the rate of shaking in the system causes relatively more ENT to be released to water, or whether the same relative percentage of ENT is released more quickly. This was accomplished by subjecting a subset of the contaminated sand/sterile seawater microcosms to shaking treatments at varied rates.

2.1.1 Hypothesis 1: Microcosm experiments were carried out over a thirty minute time course with contaminated water and sterile sands, at the end of which $16-18 \%$ of the starting quantity of ENT were transferred to sands. Microcosm experiments with contaminated sand gently submerged under sterile seawater showed that approximately $1 \%$ of bacteria in sands were released to waters. This transfer from sands occurred within the first 20 minutes of the 30 minute timeseries. These results support the hypothesis that bacteria move from high concentrations to low concentrations, but suggest that under quiescent conditions the net flux of bacteria would be into sands rather than out of sands.

2.1.2 Hypothesis 2: Shaking experiments indicated that the transfer of ENT from contaminated sand to sterile water increased with increased energy, as did turbidity. Shaking samples at 50rpm resulted in transfer of $14-17 \%$ 
of ENT from sands to water within 20 minutes, and a final turbidity of approximately $5 \mathrm{NTU}$. Increasing the rate of shaking to $100 \mathrm{rpm}$ resulted in transfer of approximately $30 \%$ of the total ENT from sand to water and a final turbidity of approximately 25NTU, which was much greater than was ever observed in the environmental samples.

\subsubsection{Appendix Figure 1: Results from shaking experiments}
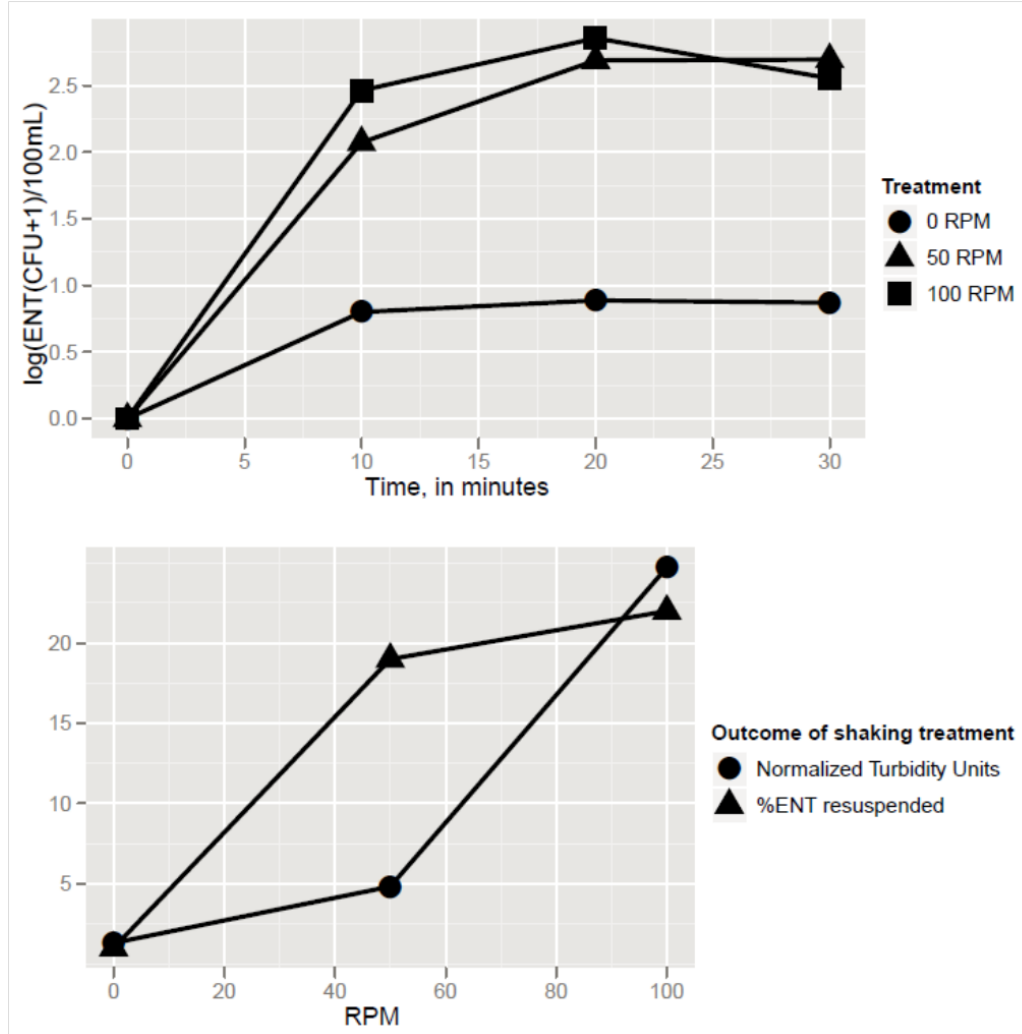